\title{
The pathogenesis of endometriosis: the endometrium - mesothelium dialogue
}

Citation for published version (APA):

Demir, A. Y. (2004). The pathogenesis of endometriosis: the endometrium - mesothelium dialogue.

[Doctoral Thesis, Maastricht University]. Universiteit Maastricht. https://doi.org/10.26481/dis.20040312ad

Document status and date:

Published: 01/01/2004

DOI:

10.26481/dis.20040312ad

Document Version:

Publisher's PDF, also known as Version of record

\section{Please check the document version of this publication:}

- A submitted manuscript is the version of the article upon submission and before peer-review. There can be important differences between the submitted version and the official published version of record.

People interested in the research are advised to contact the author for the final version of the publication, or visit the DOI to the publisher's website.

- The final author version and the galley proof are versions of the publication after peer review.

- The final published version features the final layout of the paper including the volume, issue and page numbers.

Link to publication

\footnotetext{
General rights rights.

- You may freely distribute the URL identifying the publication in the public portal. please follow below link for the End User Agreement:

www.umlib.nl/taverne-license

Take down policy

If you believe that this document breaches copyright please contact us at:

repository@maastrichtuniversity.nl

providing details and we will investigate your claim.
}

Copyright and moral rights for the publications made accessible in the public portal are retained by the authors and/or other copyright owners and it is a condition of accessing publications that users recognise and abide by the legal requirements associated with these

- Users may download and print one copy of any publication from the public portal for the purpose of private study or research.

- You may not further distribute the material or use it for any profit-making activity or commercial gain

If the publication is distributed under the terms of Article $25 \mathrm{fa}$ of the Dutch Copyright Act, indicated by the "Taverne" license above, 
The pathogenesis of endometriosis:

The endometrium - mesothelium dialogue 
(C) Ayșe Yasemin Dernir, 2004, Utrecht ISBN: 90-9017871-6

Thesis, Maastricht University

Printed by Zuidam \& Uithof, Utrecht

The cover

Epithelial to mesenchymal transitions in mesothelial cells induced by menstrual effluent (front)

The collection of menstrual effluent by using the Keeper

(back)

Financial support for printing of this thesis has kindly been provided by Abbott Diagnostics Division

Ortho-Clinical Diagnostics 


\title{
The pathogenesis of endometriosis: The endometrium - mesothelium dialogue
}

\author{
Proefschrift
}

ter verkrijging van de graad van doctor aan de Universiteit Maastricht, op gezag van de Rector Magnificus, Prof. mr. G.P.M.F. Mols, volgens het besluit van het College van Decanen,

in het openbaar te verdedigen op vrijdag 12 maart 2004 om 12.00 uur

door

Ayșe Yasemin Demir 


\section{Promotor}

Prof. dr. J.L.H. Evers

\section{Copromotores}

Dr. G.A.J. Dunselman

Dr. A.F.P.M. de Goeij

\section{Beoordelingscommissie}

Prof. dr. R.F.A. Zwaal (voorzitter)

Prof. dr. E.C.M. Mariman

Prof. dr. J.B.M.Z. Trimbos (Universiteit Leiden)

Prof. dr. rer. nat. E. Winterhager (Universitätsklinikum Essen, Duitsland)

Dr. B. Wouters 
Sen içimde kıpırdayan sabah rüzgarı, hasret kokan ciçeğimsin.

Simdi uzaklarda olsan da, her an yanımda, burada benimlesin.

\section{Anne ve Babama}

Voor mijn ouders 


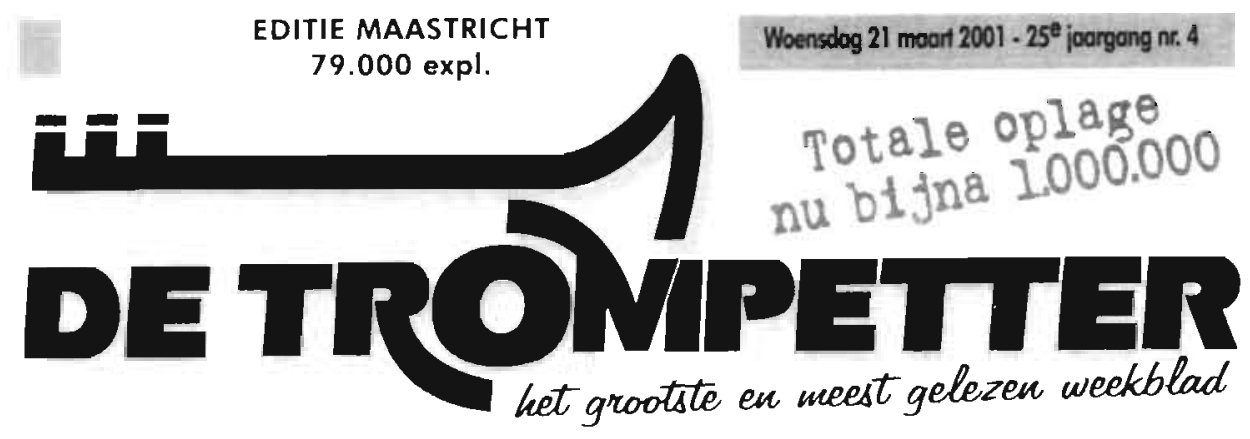

\section{Menstruatie}

Maastricht - In lang uitgestorven cufturen wero de menstruatie be schouwdals iets heiligs Aan de maan deliks terugkerende menstruatie wer. den rivelen verbonden on men veronderstelde dat menstruatiebioed zels bizondere krachiten beza!

Vrouwen werden geinstrueerd naar Vrouwen werden geinstrueerd naar hun fichaam te luisteren ten tide var neus te nemen. Men gelootde dat de spirituele energie van ben menstru. erende vrous een hoogtepunt beteik. te De vrous moest zich t t mestruatie isoleren en al haar krach ten en energie aanwenden om zich te concentreten op de vraag der vragen wat is het doel des levens

In deze tig is de houding ten aanzien van de menstruake veranderd $\mathrm{Te}$ genwoordig wordt de menstruatie niet gezien als iets heiligs Veel vrouwer vinden de center schuprisel dat gepaard gaat met onple ziengesymptomertalspyn, abonteit ehumeungheid Ondanks de verveler de karten vinden veel vrouwen he toch ook een geruststellend idee als de menstruatie weer komt Die the wist' dat het vrouxentichaam goed funchoneer ten de menstruatiecycius is min of moer deen reken van oructe. baarheid en gezondheid

\section{Endometriose}

Bị een grote groep vrouwen gaat de menstruatie echter gepaard met meer dan gemiddelde klachten, met name hehtuge pin onder in de buik. Bij een aantal van deze vrouwen is sprake van endometnose Dit is een atwilking waarbi het baarmoederslimulies niet alleen in, maar ook buten de baar. moeder aanwezig is Hoe endome: those ontstaat is nog grotendeeis or: bekend Tigdens de menstruatie word een deet yas het afoestoten baar. moedersintmies naatbutengevoerd Aangenomen wordi dat een Aangenomen word do teen deer via do enerders de zogenaamde retrograde menstru atie. Ditbaarmoederslimvies kanzich in de buikholte hechton en zich on: whkelen lot ondometriose. Endometnose kan gepaard gaan met verscheidene klachten waaronder extreme buikpin, en zelfs fot een verminderde vruchtbaamed

in het Academisch Ziekenhuis Maas. Iricht (AZM) wordt onderzoek gedaan naar endometriose. Als een van de weinige onderzoekscentra in de wereld houdt men zich bezig met de ro van menstnatiebloed bi het ontstaan van enciometriose. Sinds ongeveer ves lasir worte mensirvato zes par word menstruatievoch (menstruum) van vitwiligers gebriak! voor onderzoek naar endometriose Menstruatiebloed van gezonde vrijwilligers en van vrouwen met en dometriose wordt onderzoch! Tijden de menstruatie wordt menstruatie vocht verzameld met behulp van een in de vagina gedragen afwasbare en herbrukbare cup. de zogenaamde keepor. De keeper is gemaakt var zacht en vervormbaar rubber en heeft de vorm van een pessanum, Na hes inbrengen voeit de vrouw de keeper net meer zitter. De keeper is een m: heuvnendelik aternatief voor tarm pons en maardverband Oekeeper is pons en maas a hyguensch. omdatzich geonbacterien kunnen hechten aan he1 rubber. De keeper wordt al door vrouwen in de nele wereld gebruik? als altematie! tampon, vooral door vrouwen die een heitige menstruatie hebben en bij we maandverband en tampons tekort schieten

Door het gebruik van de keeper kunnen twee vliegen in een klap geslages worden menstruatievocht wordi op een nygeenische en mileustiendelike manier opgevangen en tevens kan he! gebruikt worden voor onderzoek naar endometnose, een aandoening die voor veel vrouwen de kwaliter! van hel leven emstig aantast

Flders op deze pagina vindt u een op cep voot vriwiligers om aan het en dometriose-onderzoek deeltenemen

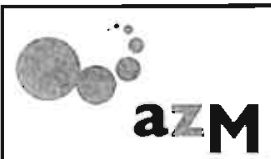

Binnen het onderzoeksinstituut Groel en Ontwikkeing van her academisct ziekentus Maastrich sordl onderzoek verncht naar het ontstaan van

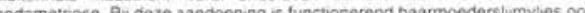

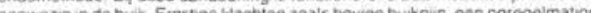

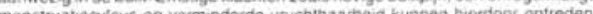

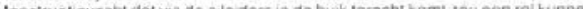

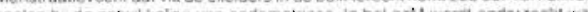

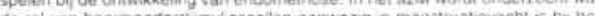
Se rol van baamoederstijmuliescellen aanwezig on menstruatievocht is by he: ontscarn van endometriose

Daarom zịn we op zoeh naar.

Vrijwilligsters die hun menstruatievocht willen verzamelen voor onderzoek

Yet behulp van sen stenele rubberan cup (de 'ecologische lampon') worst menstruatievocht vorzameid wasma het gebruikt wordt wor onderzoek Moc. informate over do menstruatie en over het endometroseonderzoek vindt tit oiders op deze pagina Bent u geinteresseerd in dit onderzoek oniot ailt it zits

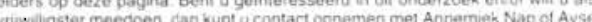
Deme Weusten atts onderzoekers in net as.

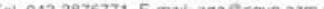


The whole of the mesoderm .... does not go through this metamorphosis, but .... a part remains closely compacted; but ultimately it is only the single layer of the cells immediately bounding the coelom .... which remains thus close together. These cells, therefore, have all the characteristics of an epithelium so that the coelom is limited by an epithelium of cuboidal cells, for which I have proposed the name mesothelium.

C. S. Minot, 1886

In Buck's Handbook of Medical Sciences 



\section{Dankwoord}

Op het punt dat ik een belangrijke fase van mijn leven ga afsluiten, realiseer ik me dat ik een hele leuke, gezellige en leerzame periode heb gehad dankzij vele mensen. Alle kleine en grote bijdragen van iedereen, ook van hen die ik vergeet te noemen, heb ik enorm gewaardeerd. Hartelijk dank, iedereen!

Ik was nog niet helemaal klaar met mijn eerste promotie in Aken toen ik met mijn naasten de vraag stelde: en hoe nu verder? Via Paul Curfs kwam ik terecht bij Prof. Geraedts. In de ontmoeting op een late namiddag waarin hij niet veel zei, gaf hij me het bondige advies om maar eens een brief met CV langs te brengen. Een en ander werd doorgebrieft naar Prof. Evers i.v.m. een vacature voor een AIO-plek in de endometrium-onderzoeksgroep.

Hierbij wil ik Paul Curfs en Prof. Geraedts van harte danken voor hun bereidwillige en voortvarende benadering waaruit adviezen voortvloeiden die bepalend waren voor mijn verdere handel en wandel in de wetenschappelijke wereld.

Het duurde een paar weken tot ik iets hoorde van de kant van de endometrium-onderzoeksgroep. Ik herinner me nog goed de vriendelijke stem van Ton de Goeij, die ik op een dag op het antwoordapparaat vond. Ton nodigde mij uit voor een sollicitatiegesprek. Niet wetend wat mij te wachten stond, bevond ik mij enkele dagen later in de kamer van Ton en Patrick. Een kwartiertje erna voegde Dr. Dunselman (alias Dr. D.) zich bij ons. Het was een bijzondere ervaring. Patrick (Groothuis) maakte op mij een buitengewoon vriendelijke indruk. Net als Ton, maar die heeft voor mij ook altijd iets vaderlijks gehad. Dr. D. kwam op mij toen wat afstandelijker over. Zowel zijn witte azM-kleding als zijn starre blikken, die meer geïnteresseerd leken in de passerende voorbijgangers achter mij dan in mij ... Later heb ik die eerste indruk bijgesteld! Ton introduceerde het project. Ik heb toen niet alles begrepen! Met name het zo essentiële woord 'zuiveren' (van endometriumcellen bij voorbeeld) heeft mij mateloos geintrigeerd; de betekenis ontging mij toen volledig. Het was uiteindelijk toch een vruchtbaar gesprek.

Deze drie heren, Dr.D., Ton en Patrick hebben in de afgelopen vijf jaar een belangrijke rol gespeeld.

Dr. D. heb ik in de loop der jaren dus beter leren kennen. Hartelijk dank dat u mij de kans hebt gegeven om dit project te starten, maar ook af te maken. De grote inzet en motivatie die ik van $u$ heb ervaren om het proefschrift af te ronden was zeer plezierig en waardeer ik zeer. Tijdens het bezoek in San Diego was de trip met de zo gelikte Amerikaanse city tour met onze stickers een bijzondere ervaring.

Ton je bent het ware taaltalent. Ik liet mijn stukken rustig achter tussen jouw inmiddels zo beroemde zwarte $0.5 \mathrm{~mm}$ potlood en het gom. Je hebt jezelf enorm ingezet in alle fasen van het proces. Je was altijd zeer steunend, motiverend, buitengewoon vriendelijk, en samen met Lucia - zeer gastvrij. Nogmaals hartelijk dank voor alles.

Patrick, ik heb veel van jou geleerd, van je altijd positieve houding naar alles en iedereen. Van je creatieve oplossingen en ideeën en je bereidheid om tijd te maken voor iedereen. 
Zonder jouw hulp en steun was het voor mij ondoenlijk geweest te bereiken wat bereikt is! Je bent een ideale maatje voor iedere AlO. Hartelijk dank voor alles. lk wens jou samen met je lieve familie een hele goede carrière toe met heel veel productieve projecten.

Mede dankzij mijn promotor Prof. Evers is de Maastricht Endometrium Research Group (MERG) zeer bekend geworden. Zonder die groep was ik niet gepromoveerd. Dank daarvoor, en voor uw medewerking.

Prof. Arends en Prof. Daemen wil ik hier ook bedanken voor de mogelijkheid die zij mij, samen met Prof. Evers, geboden hebben om in een goed laboratorium onderzoek te verrichten.

Het laboratorium voor Pathologie op het azM. Van het begin tot het eind was het ontzettend gezellig op ons lab. Hoewel het soms ook buitengewoon confronterend was te merken dat vijf levensjaren zo veel verschil maken als je omgaat met jongelui die graag heavy metal op de achtergrond horen en het in (en buiten) de koffiepauzes veelal hebben over uilderwerpen van soms dubieus nivo.

Crista, Natasja, Helen en Rick hebben voor mij heel veel betekend. Jullie stonden altijd klaar om in de moeilijke situaties bij te springen. Als ik bij voorbeeld heel af en toe niet op tijd was om een experiment af te ronden, of als er een buffer op was, of onverwachts een proefpersoon binnenliep, noem mạa op... Gelukkig kon ik jullie af en toe ook een heel klein beetje opvoeden. Bijvoorbeeld als het ging om mijn wat chaotische lab-tafel, die voor een enkeling echt niet door de beugel kon.

Hanny, en onze buren Marco, Guido en Marjolein leverden ook hun bijdragen aan de goede sfeer in het lab. Vooral de commotie rond het Limburgse Carnaval zal ik niet gemakkelijk vergeten. Hartelijk dank, dat jullie mij als vriend hebben opgenomen in jullie groep, maar ook voor de zeer gewaardeerde practisch-technische kennis waar ik zo mijn graantjes van heb meegepikt. Ik zal jullie allemaal missen, alhoewel ik de dag vrees dat jullie mij zullen 'terugpakken' met mijn 'chicken-dinges'-avontuur.

lemand die de over die labsfeer ook goed mee kan praten, en mogelijk in een nog beroerdere positie terecht kwam dan ik is mijn goede vriend Peter Moerkerk. Ik heb met jou een bijzonder leuke tijd gehad tussen alle onze 2D-PAGE bezigheden. Je was altijd klaar om mee te denken en daar waar nodig hulp te bieden, geen mogelijkheid onbenut latend. Even tussen ons; dat ongelukje "nummer 5 " houd ik strikt onder de pet.

Mijn kamergenoten waren ook deel van mijn dagelijkse bezigheden. In het begin heb ik met lvo en Els veel uitgewisseld over hun ervaringen in de researchwereld. Later kwam Manon. Ik heb van jou altijd ongelimiteerd hulp ervaren. Door jouw expertise heeft hoofdstuk 4 zijn kader gevonden. Ik ben ervan overtuigd dat je het heel ver zal schoppen, misschien wel tot een wereldberoemd wetenschapper.

Chamindie, to make a start as a foreigner in this cold, little, frog country, was not easy at all. I see that you have passed that phase and that you almost became a very good integrated 'allochtoon' in the mean time. I hope you will reach the peace and the success that you have dreamt of. Thank you very much for your contribution. 
Barry en Leon, ik wil jullie van harte danken voor jullie bereidheid om mij met de FPLC te helpen. Zonder jullie hulp was er echt geen hoofdstuk 7 gekomen.

Marjo, wij waren een beetje lotgenoten met betrekking tot de proteomics. Het was hartstikke fijn om er af en toe met jou over te praten en ideeën uit te wisselen. Hartelijk dank en veel succes met jouw promotieonderzoek.

Alle andere medewerkers van de afdeling Pathologie wil ik bedanken voor de getoonde interesse, en de naamloze hulp tijdens mijn onderzoeksactiviteiten in jullie afdeling.

Ook Carolien Koks wil ik hier bedanken. Je hebt aan dit proefschrift een wezenlijke bijdrage geleverd, met name aan hoofdstuk 3, waarvan jij de eerste auteur bent. Harteljk dank. Roel Kuijer, wetenschapper van onze toenmalige zuster-vakgroep orthopedie. Dank je wel voor jouw betrokkenheid, jouw slimme en creatieve bijdragen. Don en Martine, ook jullie bedankt voor alle interesse en praktische steun. Als ik een ingrediënt voor een bepaald experiment niet had kon ik altijd bij jullie terecht. Hier moet ik ook Edith (van de Linden) bedanken. Je hebt me soms op cruciale momenten gered.

Prof. Ramaekers en Dr. Bert Schutte van de afdeling Moleculaire Celbiologie hebben meegedacht met het zoeken naar de onderliggende mechanismen van morfologische veranderingen. Dank!

Dr. Hennie van Straaten en Johan Hekking van de afdeling Anatomie en Embryologie hebben geholpen met het opnemen van time-lapse video afbeeldingen. Dank jullie!

Meine Freunde aus Aachen; Andreas, ich möchte Dir für Deine Unterstützung, Deine Ratschläge und Hinweise danken. Ulrike Schmitz, danke für Deine Ratschläge bei den 2DPACE Techniken. Sabine, Bärbel, Tina und der Rest von Reproduktionsbiologie aus der dritten Etage, Ihr wart immer sehr herzlich, besonders hilfsbereit und immer freundlich. Danke für die schöne Zeit. Prof. Beier, Sie haben es möglich gemacht, daß ich meine 2D-PAGEArbeit in Ihrem Institute durchführen konnte. Danke.

Zo simpel is het: geen omentum of menstruatiebloed, geen proefschrift. De stat en de assistenten van de afdeling Obstetrie en Gynaecologie, hartelijk dank voor jullie medewerking bij de afname van de omentumstukken. Natuurlijk zou dit onderzoek ook nooit uitgevoerd zijn zonder de medewerking van patiënten en vrijwilligers. Dank voor jullie bijna maandelijkse bijdrage.

De leden van de commissie (Prof. Zwaal, Prof. Mariman, Prof. Trimbos, Prof. Winterhager, Dr. Wouters) wil ik danken voor hun kritische beoordeling en constructieve commentaien van het manuscript.

De laatste fase van mijn promotie heb ik op het UMC-Utrecht temidden van mijn huidige ploeg gedaan. Mijn opleider, Prof van Solinge, Wouter, je hebt mij vertrouwen geschonken, gemotiveerd en me enorm de ruimte gegeven om dit werk af te ronden. Ik ben evan overtuigd dat dit bij een andere baas onmogelijk was geweest. Ik ben blij en voel me gesteund dat je, weliswaar als opponent, zitting neemt in de commissie. In de komende tijd hoop ik me voor jou in te kunnen zetten, naar jouw volle tevredenheid.

Mijn kamergenoten Albert Huisman en Karen Vroonhof, mijn eerstejaarssupervisor Hans 
Kemperman en de rest van de stafleden, de hele kaderploeg van het CDL en de dames van het secretariaat: hartelijk dank voor jullie interesse, bemoedigende woorden en voor jullie bijdragen aan de prettige werksfeer. De collega's van de rode celgroep, met wie ik mijn toekomstige onderzoeksactiviteiten zal ontplooien, ook jullie wil ik bedanken voor alle interesse. In het bijzonder mijn lotgenoot Richard, die in verband met zijn eigen promotie precies weet wat ik heb doorgemaakt.

Annemiek, wat ben ik blij jou te hebben leren kennen. Dat is een leuke kant van het promoveren: je verricht niet alleen onderzoek maar maakt af en toe ook zeer goede vrienden. Elk schoolreisje dat wij samen ondernamen (Lousanne, San Diego, Washington DC) werd een buitengewoon gezellige evaring. Ik heb er enorm van genoten. Fijn dat je mijn paranimf wil zijn!

Greetje en Jan, jullie hebben veel voor ons betekend: als achterburen, oppas, en zeer goede vrienden. Jullie stonden altijd onvoorwardelijk voor ons klaar. En nog steeds! Wat is dat een heerlijk gevoel. Vooral voor iemand als ik, die niet is opgegroeid met de strikte Europese regels, maar pas sinds de laatste paar jaar een agenda bij zich draagt. Timur heeft veel van jullie genoten en van jullie geleerd; daarvoor ben ik erg dankbaar.

Ruken en Gökhan, onze zeer dierbare vrienden. Jullie hebben in de afgelopen tijd voor ons/mij heel veel betekend. Jullie zijn mijn Turkse familie die ik in Nederland zo vreselijk mis. Jullie zijn de mensen bij wie mijn 'Turkse ik' honderd procent zichzelf kan zijn. Bovendien hebben jullie vaak op Timur gepast, waardoor ik vele extra experimenten heb kunnen doen. Dank jullie voor jullie liefdevolle steun en interesse.

Ruken ve Gökhan, çok sevgili dostlarimiz. Bu geçen zamanda bizim/benim için çok şey ifade ettiniz. Sizler benim burada hep o çok özledig̈im Türkiye'deki allem oldunuz, sizler benim o eski tanıdık ben olabildiğim, rahatlayabildiğim, sınırsız ifade özgürlügüümün oldug̃u hoș sohbet ortamları oldunuz. Sizin sayenizde bu kitapto torif edilen pek çok deney ekstra-zamanlarda yapıldı. Sevginiz, ilginiz, desteğiniz, motive edici sözleriniz için çok teșekkürler. Kahve follarında hep o birbirimize söyledig̈imiz pozitif enerjinin sizlerin geleceg̃inde kütle formuna dönüșeceg̃i gün çok ama çok yakın.

Mijn schoonfamilie: Leo-Joepie, Lonneke-Frank, Jos-Marianne, Bas-Esther, An: jullie zijn een onvoorwaardelijke steun geweest in de afgelopen periode. Jullie waren altijd zo oprecht geinteresseerd en dat betekende voor mij heel veel. Het inspringen in moeilijke situaties is een van jullie expertises. Hartelijk dank voor jullie liefde, flexibiliteit en begrip. Jos, dankzij jou is hoofdstuk 4 statistisch gezien van topkwaliteit geworden. Ik vrees dat men mij er iets over gaat vragen, maar dan zal ik onmiddellijk naar jou wijzen. Bas, met het starten van een nieuwe baan, d.w.z. O.a. deze promotie-AlO-baan ben je de wijze raadgever geweest. Dank jullie wel!

Mijn familie in Turkije, mam en pap, jullie hebben mij zo'n sterke basis gegeven. Dat is meer dan genoeg om waar dan ook ter wereld iets op te bouwen. Dit boekje dat met jullie oneindige liefde en steun zijn body heeft gevonden, is eigenlijk jullie verdienste. Dank jullie voor alles. 
Göksemin en Feridun, ook dank jullie voor jullie enorme steun, motiverende woorden, interesse en liefde.

Türkiye'deki ailem, anneciḡim ve babacıg̃ım, bana o kadar güçlü bir temel verdiniz ki, dünyanın neresinde olursam olayım, hangi ortamin içinde bulunursam bulunayım, üstüne birşeyler koymam için yeter de artar bile. Bitmez sevgi ve desteğiniz ile ortaya çkan bu kitap sizin eseriniz. Herşey için çok ama çok teşekkürler.

Göksemin ve Feridun sizlere de büyük desteg̃iniz, motive edici sözleriniz, tatlı ilginiz ve her an derinden hissettig̈im sevginiz için teșekkürler.

Last but not the least, mijn mannen thuis. Jullie zijn mijn 'stabiele factor' geweest waarop ik echt altijd kon rekenen. Leoke je had er alles voor over om mij op allerlei terreinen te helpen. Je had alle begrip als ik weer eens later thuis kwam of onverwachts naar het lab moest. Je bleek jouw drukke programma toch vrijwel altijd weer te willen en kunnen aanpassen aan mijn werkzaamheden. Zonder jou was het echt niet zo ver gekomen. Çok çok teşekkürler canimtje.

Timur, kușum, je bent de allerliefste en allermakkelijkste zoon van de hele wereld. Je hebt jouw moeder in de afgelopen tijd heel vaak moeten missen, en je moeder jou! Ik beloof je dat wij dat gaan inhalen, samen met jouw ongeboren zusje of broertje Tok. 


\section{Contents}

Abbreviations

Chapter 1

Introduction

1.1. Endometriosis

1.1.1. General characteristics

1.1.2. Pathogenesis

1.2. Menstruation

1.2.1. General characteristics

1.2.2. Retrograde menstruation

1.3. The mesothelium

1.3.1. General characteristics

1.3.2. Mesothelium regeneration and repair

1.3.3. Mesothelial plasticity

1.3.4. Growth, cellular adhesion and dissemination on the mesothelium

1.3.5. In summary

\section{Chapter 2}

Scope of the thesis

\section{Chapter 3}

Menstruum induces changes in mesothelial cell morphology

\section{Chapter 4}

Morphological changes in mesothelial cells induced by shed menstrual endometrium in vitro are not primarily due to apoptosis or necrosis

\section{Chapter 5}

Menstrual effluent induces epithelial to mesenchymal transitions in mesothelial cells

\section{Chapter 6}

Proteome analysis of human mesothelial cells during epithelial to mesenchymal transitions induced by shed menstrual effluent

\section{Chapter 7}

Molecular characterization of soluble factors from human menstrual effluent that induce epithelial to mesenchymal transitions in mesothelial cells 


\section{Chapter 8}

General discussion and future perspectives

\section{Summary}

153

Samenvatting

157

Özet

161

Curriculum Vitae

165

List of publications

167

Appendix

170 


\section{Abbreviations}
DMEM: Dulbecco's modified Eagle's medium
ECM: extracellular matrix
EGF: epithelial growth factor
EMT: epithelial to mesenchymal transitions
ERK: extracellular response kinase
FGF: fibroblast growth factor
FPLC: $\quad$ fast performance liquid chromatography
GMS-A: $\quad$ growth medium supplement-A
HGF/SF: hepatocyte growth factor/scatter factor
HOMEC: human omental mesothelial cells
IFN- $\gamma$ : $\quad$ interferon- $\gamma$
IGF:
insulin like growth factor
IL-1 $\beta$ : interleukin-1 $\beta$
MAP: mitogen activated kinase
MEM: $\quad$ minimum essential medium
MMPs: matrix metalloproteinases
NO: $\quad$ nitric oxide
iNOS: $\quad$ inducible nitric oxide synthase
PAls: plasminogen activator inhibitors
PDGF: $\quad$ platelet derived growth factor
$\mathrm{Pl}_{3} \mathrm{~K}: \quad$ phosphatidylinositol-3 kinase
RPMI: $\quad$ Roswell Park Memorial Institute
SDS-PACE: $\quad$ sodium dodecyl sulphate-polyacrylamide gel electrophoresis
TF: tissue factor
TCF- $\beta$ : $\quad$ transforming growth factor $\beta$
TIMPS: $\quad$ tissue inhibitors of matrix metalloproteinases
TNF- $\alpha$ : $\quad$ tumour necrosis factor- $\alpha$
tPAs: $\quad$ tissue plasminogen activators
2D-PAGE: $\quad$ two dimensional-polyacrylamide gel electrophoresis 


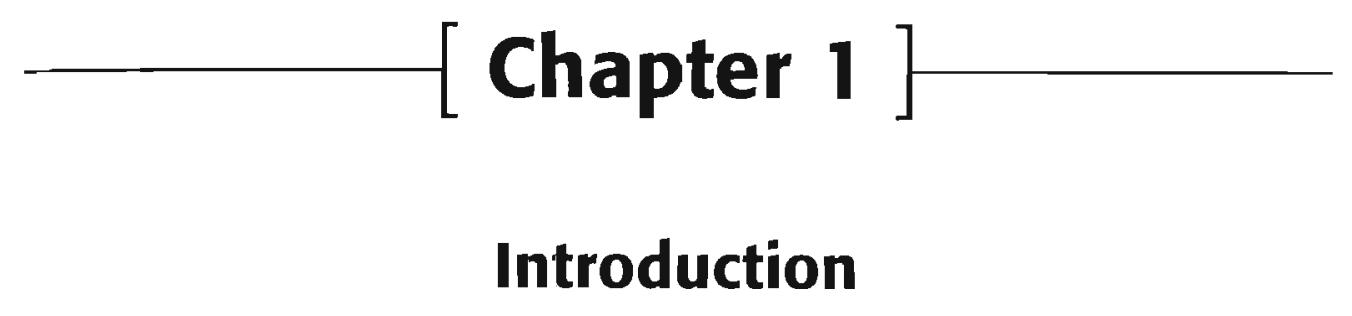


Chapter I 


\subsection{Endometriosis}

\section{I.J. General characteristics}

Endometriosis is the presence of functional endometrial glands and stroma at locations outside the uterine cavity. It is a chronic, benign disease, which is associated with pelvic pain, dyspareunia and dysmenorrhoea. Although not life-threatening it may disrupt the marital, sexual and social life of the women afflicted. Adhesions secondary to active endometriotic lesions may impede the tubo-ovarian relationship and thus lead to subfertility.

In endometriosis three forms can be distinguished: peritoneal endometriosis, ovarian cystic endometriosis and endometriosis of the rectovaginal septum. It has been argued that these forms are three separate entities, each with its own pathogenesis, symptomatology. natural course of disease and treatment (Nisolle and Donnez, 1997). Apart from the typical black, powder burn peritoneal lesions, a variety of atypical lesions has been described (Redwine, 1990). Endometriosis of the rectovaginal septum histologically resembles adenomyotic lesions observed in the myometrium. Additionally, endometriosis can be found in the intestines, the bladder and occasionally at extra-abdominal sites.

Despite extensive basic and clinical research in the last decades, our knowledge of the pathogenesis, aetiology, and pathophysiology of endometriosis has slowly progressed.

The prevalence of symptomatic endometriosis has been estimated at $10 \%$ in the general population (Eskenazi and Warner, 1997) and at $20-90 \%$ in women with pelvic pain and infertility (Hill, 1997). Interestingly, a high prevalence (40-50\%) of peritoneal endometriosis was found during laparoscopy in a comparable, prospective study regardless of the indication for laparoscopy (Balasch et al., 1996). This supports the notion that asymptomatic endometriosis is a phenomenon occurring in women intermittently during their reproductive life (Koninckx, 1994).

\subsubsection{Pathogenesis}

Several theories have been proposed to explain the pathogenesis of endometriosis These theories can be summarized as follows

The "in situ development theory" assumes that ectopic endometrium develops in situ from local tissues, such as the epithelium covering the ovaries and the: embiyonic cell rests of Müllerian origin, secondary to inflammatory processes, hormonal influences or other, unknown, factors. This theory implies that peritoneal endometriosis results from in situ metaplasia of the totipotent mesothelial serosal cells (Haney, 1990; Fujii, 1991; Suginami, 1991). The observations that endometriosis predominantly occurs if endometrium is present and that males are spared from this disease make the concept of metaplasia to explain endometriosis less likely. 
Proponents of the "induction theory" assume that substances released by the degenerating uterine endometrium are capable to induce undifferentiated mesenchyme to undergo metaplasia, resulting in ectopic endometrial tissue (Levander and Normann, 1955; Merrill, 1966; Schenken, 1989). Culturing ovarian surface epithelial cells with endometrial stroma cells in the presence of oestrogens resulted in gland formation, which was positive for cytokeratins and epithelial membrane antigen (Ohtake et al., 1999). To meet the criteria for the definition of endometriosis both endometrial epithelium and stroma should be present in the ectopic lesion. However, no direct evidence for the formation of endometrial stroma at the end of the process of induction has been reported.

A third theory is the transplantation theory, which was proposed by Sampson on the basis of his clinical observations. According to this theory viable cells in menstrual effluent can disseminate through the Fallopian tubes by retrograde menstruation and can adhere to the peritoneum with subsequent implantation (Sampson, 1927). A substantial amount of clinical and experimental data supports this hypothesis (Te Linde and Scott, 1950; Koninckx et al., 1980; Blumenkrantz et al., 1981; Halme et al., 1984; Bartosik et al., 1986; Jenkins et al., 1986; Liu and Hitchcock, 1986; Sanfilippo et al., 1986; Olive and Henderson, 1987; Barbieri et al., 1992; D'Hooghe et al., 1995; van der Linden et al., 1995). In particular the anatomical distribution of the endometriotic lesions and the presence of viable endometrium cells in the peritoneal fluid of patients with patent tubes make this theory highly plausible. latrogenic, lymphogenic and haematogenic routes of dissemination other than the transtubal route appear to be responsible for the rare extraperitoneal locations of endometriosis. However, none of the proposed theories, neither alone nor in combination, can account for all ectopic locations of endometriosis.

The theories on the pathogenesis of endometriosis describe the mechanism of initiation of endometriotic lesions, i.e. they describe how the peritoneal lesion develops. The explanation why women develop endometriosis, i.e. the aetiology, is equally uncertain. A growing body of evidence indicates that a combination of genetic (Malinak et al., 1980; Simpson et al., 1980; Kao et al., 2003), hormonal (Zeitoun and Bulun, 1999), immunologic (Braun and Dmowski, 1998; Dmowski et al., 1998) and anatomic factors (Jenkins et al., 1986) contribute to the formation and development of the ectopic foci.

Assuming that Sampson was right, the adhesion of retrogradely shed viable endometrium tissue to the mesothelium, which forms the peritoneal surface, is one of the most important determinants of the early pathogenesis of endometriosis. We have shown previously in vitro that endometrium from all phases of the cycle preferentially adheres to submesothelial structures at locations where the mesothelial lining is not intact (Groothuis et al., 1998a, b; Koks et al., 1999). Or in other words: an intact mesothelial lining may prevent the adhesion of endometrial tissue and hence the development of endometriosis. However, in the in vitro model used it is not clear whether the damage to the mesothelium was caused by tissue handling or by the menstrual endometrium itself. If the 
latter is the case the exact mechanism by which shed menstrual endometrium affects mesothelial lining is unknown. In the following paragraphs the process of menstruation and the structure as well as the function of mesothelium will be discussed.

\subsection{Menstruation}

\subsubsection{General characteristics}

The menstrual cycle is a result of the regular occurrence of ovulation in the absence of pregnancy throughout the reproductive life of women. The cycle has an interval of 24 to 35 days and is divided into three phases: the proliferative phase, the secretory phase and the menstrual phase.

The proliferative phase starts after the menstrual period. This phase continues until ovulation during which time the endometrial glands proliferate under the influence of oestrogen. A variable length, a low basal body temperature, development of ovarian follicles, vascular growth of the endometrium and secretion of oestrogen from the ovary characterize it.

The secretory phase is the second part of the cycle and extends from ovulation until the onset of menses. Under the influence of progesterone, the endometrial glands develop the secretory status necessary for implantation of the embryo. It has a fairly constant duration of 12-16 days. During this phase the corpus luteum is formed in the ovary secreting progesterone, which raises the basal body temperature. Histology of the endometrium reveals gland tortuosity and secretion, stromal oedema, and a decidual reaction.

Menstruation is a morphological sequence of events that consists of a rapid reduction of the endometrial wall due to fluid loss and tissue lysis (Markee, 1946). A focal damage of the superficial functional layer already occurs at the end of the secretory phase before bleeding commences (Ludwig and Spornitz, 1991).

The functional layer of the endometrium is entirely expelled and again reconstructed in each menstrual cycle. Its blood supply is provided by an intricate system of spiral arteries, capillary networks, veins, venous lakes and arterio-venous anastomoses. Furthermore, acute infiltration of leucocytes and lymphocytes occurs in the endometrium prior to menstruation, which contributes to the extracellular matrix degradation and vasoconstriction (Salamonsen and Lathbury, 2000). When the blood levels of oestrogen and progesterone rapidly decline as a result of the regression of the corpus luteum, the endometrial functional layer immediately exhibits signs of regression, shrinkage and atrophy. This results in the formation of vasoactive substances, which, by local action, trigger the ischemic and hemorrhagic vascular phenomena that cause the necrosis, and menstrual desquamation of this layer of the endometrium (Lockwood et al., 1997; Critchley et al., 2001). Many factors are considered to be involved in the regulation of bleeding and tissue shedding in human endometrium. These factors include tumour necrosis factor- $\alpha$ (TNF $\alpha$ ), tissue fac- 
tor (TF), tissue plasminogen activators (tPAs), plasminogen activator inhibitors (PAls), matrix metalloproteinases (MMPs), and tissue inhibitors of matrix metalloproteinases (TIMPs) (Tabibzadeh, 1996).

The basal layer of the endometrium is thin and is situated deeply, in direct contact with the myometrium. Leyendecker and coworkers have suggested that the basal layer of endometrium, which has a stem cell character, also becomes dislocated during menstrual desquamation (Leyendecker et al., 2002). These authors also stated that the basal layer of endometrium may provide all the archimetrial components such as epithelial and stromal endometrium as well as peristromal muscular tissue for the formation of the ectopic foci. This, however, still needs to be substantiated further.

\subsubsection{Retrograde menstruation}

Several studies have reported the presence of blood in peritoneal fluid of menstruating patients undergoing procedures such as culdoscopy, peritoneal dialysis or laparoscopic sterilization: referred to as retrograde menstruation (Blumenkrantz et al., 1981; Halme et al., 1984). Moreover, during retrograde menstruation shed endometrial tissue is regurgitated into the peritoneal cavity through the Fallopian tubes (Kruitwagen et al., 1991; van der Linden et al., 1995). This endometrial tissue has been shown to be viable (Kruitwagen et al., 1991; van der Linden et al., 1995). Since retrograde menstruation is a common physiologic event in women with functional tubes, it has been suggested that all women with patent tubes have endometrium tissue in their abdominal cavity at regular intervals and thus, during their reproductive life, will be at risk to develop endometriosis.

The presence of retrogradely shed menstrual endometrium evokes a peritoneal inflammatory response, which is suggested to have the aim to incapacitate and to remove the endometrium tissue effectively (Haney et al., 1981; Braun and Dmowski, 1998; Braun et al., 1998; Santanam et al., 2002). Nevertheless, endometrial tissue survives, adheres to the peritoneum and develops into an ectopic endometriotic implant (Koninckx et al., 1999). It has been shown in monkeys that increased amounts of retrogradely shed menstrual endometrium result in more endometriosis (D'Hooghe et al., 1994). This is also illustrated by the fact that reproductive factors that relate to increased exposure to menstruation such as a shorter cycle length, longer duration of flow or reduced parity are associated with a higher risk of developing endometriosis (Darrow et al., 1993).

Endometrial tissue is able to adhere to serosal surfaces, it produces matrix metalloproteinases, it is highly angiogenic and it can generate its own growth signals (Groothuis et al., 1998b; Zeitoun and Bulun, 1999; Koks et al., 2000b; Maas et al., 2001). Furthermore, menstrual effluent and peritoneal fluid contain factors such as proteases, cytokines and growth factors, that may actively regulate the process of adhesion and implantation (Kupker et al., 1998; Sharpe-Timms, 2001). Presumably the peritoneal surface is also actively involved in these processes. Prior to adherence and implantation shed menstrual 
endometrium interacts with the mesothelial lining of the peritoneum. The nature of this initial contact is unclear, however.

\subsection{The mesothelium}

\subsubsection{General characteristics}

The mesothelium is a confluent monolayer of specialized epithelial cells that covers the entire surface of the serosal cavities (pleural, pericardial and peritoneal) and the organs in these cavities. At most sites, the layer resembles a simple epithelium upon a continuous basement membrane, consisting of cells with a polarized morphology, conspicuous apical microvilli and occasional cilia (Figure I). The basement membrane overlies conncitive tis. sue consisting of fibroblasts, collageri fibers, adipocytes, leucocytes and an abundant sipply of lymphatics and microvessels. Although the mesothelium is composed predominantly of elongated, flattened, squamous-like cells, also cuboidal mesothelial cells can be found in various areas. Moreover, cuboidal mesothelial cells can appear aifter injury or stimulation of serosal surfaces (Whitaker and Papadimitriou, 1985; Fotev et al, 1987; Michailova et al., 1999). Mesothelial cells have well-developed cell-cell junctional complexes including tight junctions, adherens junctions, gap junctions and desmosomes (Figure 1) (Pelin et al., 1994). Stomatal openings, 3-12 um in diameter, are generally found in those regions where cuboidal mesothelial cells are present (Leak and Rahit, 1978). These openings provide direct access to the underlying submesothelial lymphatic,
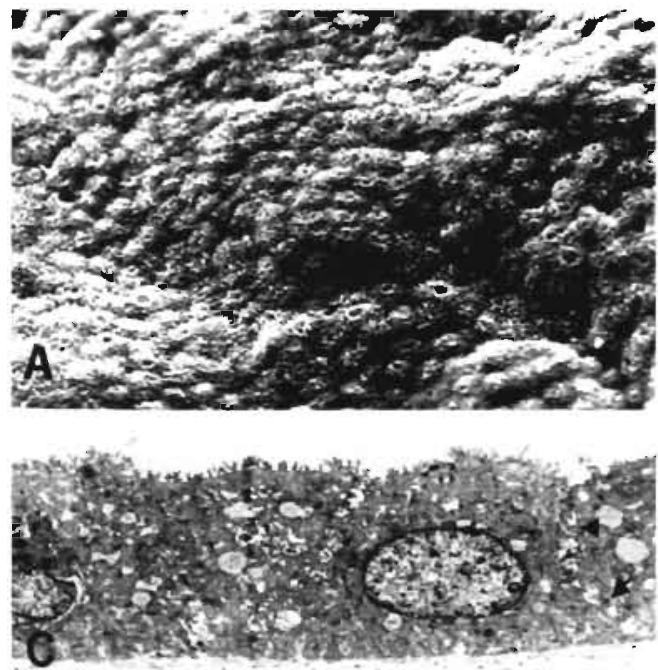

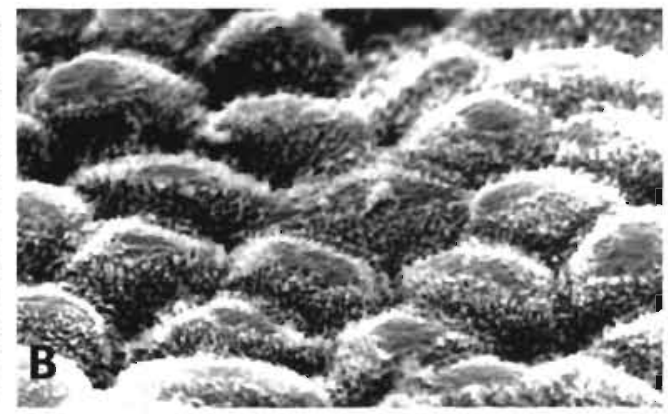

Figure 1: Scanning and electron micrographs to show the mesothelial monolayer covered with microvilli ( $A$ \& B) and also the intercellular junctions at the lateral sides of mesothelial cells interdigitating with those of adjacent cells ( $C$, arrowheads). Courtesy Dr. P. Groothuis. 
system, allowing rapid removal of fluid, cells, bacteria and particles from the serosal cavities (Miura et. al., 2000). During embryonic development, the mesothelium is derived from mesoderm, but it is characterized by dual epithelial/mesenchymal properties (LaRocca and Rheinwald, 1984). Morphological and histochemical studies have demonstrated that mesothelium of mammalian origin has similar characteristics, irrespective of species or anatomical sites (Whitaker et al., 1982). However, using scanning electron microscopy we have observed that the peritoneal surfaces of mice and rabbits differ considerably from human peritoneum.

Furthermore, the mesothelium expresses proteoglycans and hyaluronic acid, which provide a protective barrier and a frictionless interface for the free movement of opposing organs and tissues (Andrews and Porter, 1973). It also plays an important role in fluid and cell transport, initiation and resolution of inflammation, tissue repair, lysis of fibrin deposits preventing adhesion formation and protection against invading micro-organisms and possibly tumour dissemination (Mutsaers, 2002).

\subsubsection{Mesothelium regeneration and repair}

Injury of the mesothelial layer triggers a series of events that leads to the regeneration of mesothelium and to the initiation of repair processes. Mesothelial cells have the capacity to secrete a variety of growth factors and extracellular matrix (ECM) molecules that are involved in this healing process. Growth factors initiate the prolferation and migration of mesothelial cells and repair cells on top of the ECM molecules, which are exposed or deposited at the wound site to cover the injury (Mutsaers et al., 1997). The healing process begins upon the arrival of a population of round cells at the wound surface within 24 hours of injury and is completed 7-10 days later when the area is covered by cells, which display all the characteristics of mesothelial cells (Whitaker and Papadimitriou, 1985; Mutsaers et al., 2002). Several origins have been proposed for the regenerating mesothelium, including centripetal migration of mesothelial cells, exfoliation of mature proliferating mesothelial cells from adjacent or opposing surfaces, pre-existing free floating serosal reserve cells, submesothelial mesenchymal precursors, transformation of serosal macrophages and bone marrow derived circulating precursors (Whitaker and Papadimitriou, 1985; Mutsaers et al., 2000; diZerega and Campeau, 2001). Cell labeling studies (Fotev et al., 1987; Foley-Comer et al., 2002) and kinetic techniques (Whitaker and Papadimitriou, 1985) have shown that the last three assumptions are unlikely to be the origin of mesothelial cells. In the current understanding of mesuthelial healing it is assumed that mesothelial cells diffusely regenerate over the denuded surface and that these cells originate from the exfoliation of mature proliferating cells and from the preexisting free floating serosal reserve cells. 


\subsubsection{Mesothelial plasticity}

Mesothelial cells have a striking degree of plasticity in their state of differentiation. They may adopt either an epitheloid or fibroblastoid morphology and express cytoskeletal elements characteristic of both cell types, in vitro and in vivo (Connell and Rheinwald, 1983; LaRocca and Rheinwald, 1984; Van Muijen et al., 1987). For example, during mesothelial repair mesothelial cells lose their cell-cell junctions, divide, and adopt a fibroblast-like morphology while scattering across and covering the wound surface. In addition, certain growth factors and hormones induce variations in cellular response. For example, these cells display a mitogenic response to transforming growth factor- $\beta$ (TGF- $\beta$ ) and platelet derived growth factor (PDCF) (Gabrielson et al., 1988), which is unusual for epithelial cells. Mesothelial cells grown in delipidized serum adopt a fibroblast morphology and express predominantly vimentin, whereas celis grown in normal serum display an epitheloid morphology and express cytokeratins as well as vimentin (Marshall et al., 1993). Epithelial growth factor (EGF) also stimulates transformation of cultured mesothelial cells to a fibroblast phenotype (van Rossen et al., 2001), whereas culture of mesothelial cells in the presence of hepatocyte growth factor/scatter factor (HGF/SF) disrupts cell-cell junctions and induces scattering and enhanced mesothelial cell migration (Warn et al, 2001).

Thus, the mesothelial cell phenotype results from a dynamic equilibrium between the transcription and translation machinery and the local environment. In women the mesothelium is exposed at regular intervals to menstrual effluent that contains inflammatory cells and regulatory factors. This specific environment, the peritoneal fluid, conceivably affects the phenotype and the biological behaviour of mesothelial cells.

\subsubsection{Growth, cellular adhesion and dissemination on the mesothelium}

Results from studies on the adhesion of endometrial tissue to human amnion or peritoneum in vitro have strongly suggested that adhesion of endometrial fragments preferably occurs to the exposed extracellular matrix underneath the damaged mesothelium and not to intact mesothelium (Figure 2) (van der Linden et al., 1996; Groothuis et al., 1998a, 1999; Koks et al., 1999; Dunselman et al., 2001). The interaction between the adhesion molecule integrin $\alpha 6 \beta 1$ and the extracellular matrix protein laminin was shown to be a critical step in this event (Koks et al., 2000a). In contrast, other studies show that individual endometrial stromal cells and small epithelial glands are also able to attach to the intact mesothelium (Witz et al., 1999; Witz et al., 2001), through CD44-hyaluronic acid interaction (Dechaud et al, 2001). Furthermore, individual endometrial stromal cells can migrate through a mesothelial cell monolayer within 18-24 hours (Witz et al., 1999). However, it has been shown that individual preparations of stromal cells and epithelial glands are not able to form endometriotic lesions in monkeys and in the chorioallontoic 
membrane model (Sillem et al., 1996; Nap et al., 2003). Endometriotic lesion formation only occurs when endotmetrium tissue architecture is maintained.

Studies, which examine tumour spread and recurrence after surgery, show that traumatized mesothelial surfaces are privileged sites for cell adhesion (Cunliffe and Sugarbaker, 1989; Sugarbaker et al., 1989). Trauma of the peritoneum and the ensuing inflammatory response lead to up-regulation of mesothelial cell adhesion molecules such as integrins, thus promoting the anchoring of tumour cells at local and distant sites (Hofer et al., 1998; Leavesley et al., 1999). Moreover, tissue handling during laparotomy and use of $\mathrm{CO}_{2}$ gas in laparoscopy negatively affect mesothelium, which may lead to enhanced tumour growth and peritoneal tumour dissemination (Bouvy et al., 1996; Reymond et al., 1998; van den Tol et al., 1998). Also, denudation of the peritoneum in patients subject to continuous ambulatory peritoneal dialysis (Andreoli et al., 1994) leads to increased intraabdominal dissemination of cancer cells compared to non-dialysis patients (Bargman, 2000).

The main mechanism of attachment to exposed submesothelial connective tissue is the binding of the cells via integrins (Nakashio et al., 1997; Schlaeppi et al., 1997). However, many studies have demonstrated that tumour cells also adhere to the hyaluronan pericellular coat of mesothelial cells, which is an important step in the peritoneal spread of
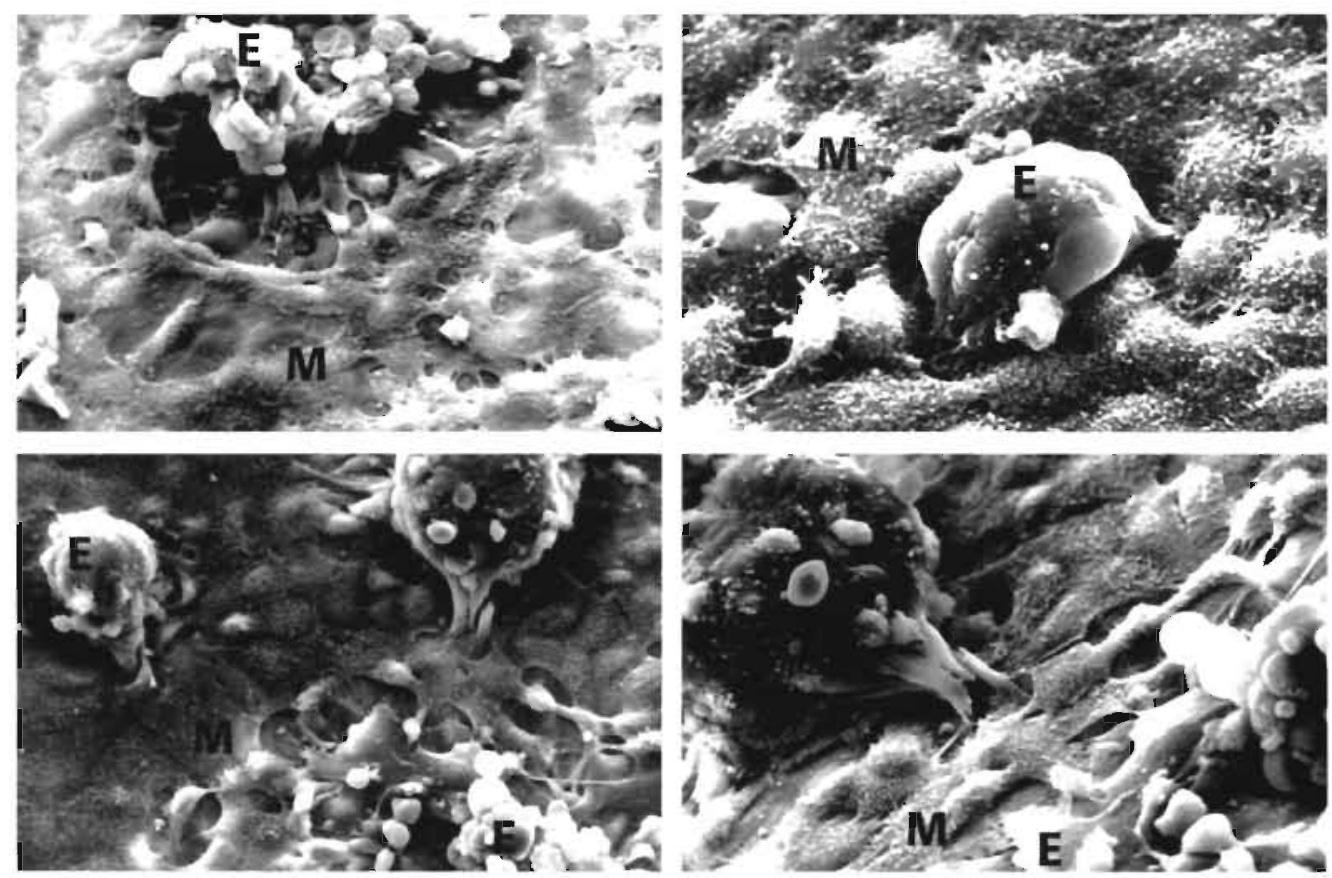

Figure 2: Scanning electron micrographs to show endometrium frogments adhered to submesothelial areas on the peritoneum. E: endometrium, M: mesothelium, S: submesothelial matrix. Courtesy Dr. P. Groothuis. 
ovarian and colorectal cancer (Schlaeppi et al., 1997; Catterall et al., 1999; Casey and Skubitz, 2000; Harada et al, 2001).

During ectopic dissemination, tumour cells induce morphologic alterations in the mesothelium. These changes include disruption of intercellular junctions, which leads to retraction of mesothelial cells, exposure of underlying extracellular matrix, and the subsequent attachment and proliferation of tumour cells on extracellular matrix (Kiyasu et al., 1981; Niedbala et al., 1985; Lee et al., 1988; Kishikawa et al., 1995). This reaction of the mesothelial cells is similar to that reported for endothelial cells in vitro by Kramer and Nicolson (Kramer and Nicolson, 1979), who found a correlation between the invasive or malignant potential of a variety of cell types and their ability to induce cultured endothelial cells to retract. Rat hepatoma cells in the ascites are poorly adhesive to peritoneal mesothelial cells in vitro, since these cells did not cause the mesothelial cells to retract and were unable to invade the peritoneum in vivo (Rovensky et al., 1980).

\subsubsection{In summary}

The peritoneal membrane is lined with a monolayer of mesothelial cells. These cells act as a protective barrier and secrete various molecules such as cytokines, chemokines, proteases, growth factors, eicosanoids and adhesion molecules that regulate peritoneal permeability, tissue repair, local host defense and ectopic dissemination of tumour cells/tissue. A variety of stimuli can change the differentiation state of mesothelial cells, which results in a different morphology. We hypothesize that the mesothelial cells are able to change their morphology in response to menstrual fluid which contains a variety of growth factors, cytokines, chemokines and proteinases. As a result intracellular spaces will be created and extracellular matrix molecules will be exposed to allow adhesion of endometrium tissue. This is considered to be a factor for the development of endometriosis.

\section{References}

Andreoli, S. P., Mallett, C., Williams, K., McAteer, J. A., Rothlein, R. and Doerschuk, C. M. (1994) Mechanisms of polymorphonuclear leukocyte mediated peritoneal mesothelial cell injury. Kidney Int, 46, 1100-1109.

Andrews, P. M. and Porter, K. R. (1973) The ultrastructural morphology and possible functional sig. nificance of mesothelial microvilli. Anat Rec; 177, 409-426.

Balasch, J., Creus, M., Fabregues, F. Carmona, F., Ordi, J., Martinez-Romar, S. and Vanrell, J. A. (1996) Visible and non-visible endometriosis at laparascopy in fertile and infertile women and in patients with chronic pelvic pain: a prospective study. Hum Reprod, 11, 387-391.

Barbieri, R. L., Callery, M. and Perez, S. E. (1992) Directionality of menstrual flow: cervical os diameter as a determinant of retrograde menstruation. Fertil Steril, 57, 727-730.

Bargman, J. M. (2000) Neoplasia in dialysis patients: pathophysiology, epidemiology, and screening. Adv Perit Dial, 16, 93-96 
Bartosik, D., Jacobs, S. L. and Kelly, L. J. (1986) Endometrial tissue in peritoneal fluid. Fertil Steril, 46, 796-800.

Blumenkrantz, M. J., Gallagher, N., Bashore, R. A. and Tenckhoff, H. (1981) Retrograde menstruation in women undergoing chronic peritoneal dialysis. Obstet Gynecol, 57, 667-670.

Bouvy, N. D., Marquet, R. L., Jeekel, H. and Bonjer, H. J. (1996) Impact of gas(less) laparoscopy and laparotomy on peritoneal tumour growth and abdominal wall metastases. Ann Surg, 224, 694700.

Braun, D. P. and Dmowski, W. P. (1998) Endometriosis: abnormal endometrium and dysfunctional immune response. Curr Opin Obstet Gynecol, 10, 365-369.

Braun, D. P., Gebel, H. Rana, N. and Dmowski, W. P. (1998) Cytolysis of eutopic and ectopic endometrial cells by peripheral blood monocytes and peritoneal macrophages in women with endometriosis. Fertil Steril, 69, $1103-1108$.

Casey, R. C. and Skubitz, A. P. (2000) CD44 and $\beta 1$ integrins mediate ovarian carcinoma cell migration toward extracelluiar matrix proteins. Clin Exp Metostosis, 18, 67-75.

Catterall, J. B., Jones, L. M. and Turner, G. A. (1999) Membrane protein glycosylation and CD44 content in the adhesion of human ovarian cancer cells to hyaluronan. Clin Exp Metastasis, 17, 583591

Connell, N. D. and Rheinwald, J. G. (1983) Regulation of the cytoskeleton in mesothelial cells: reversible loss of keratin and increase in vimentin during rapid growth in culture. Cell, 34, 245-253.

Critchley, H. O., Kelly, R. W., Brenner, R. M. and Baird, D. T. (2001) The endocrinology of menstruation-a role for the immune system. Clin Endocrinol, 55, 701-710.

Cunliffe, W. J. and Sugarbaker, P. H. (1989) Gastrointestinal malignancy: rationale for adjuvant therapy using early postoperative intraperitoneal chemotherapy. Br I Surg, 76, 1082-1090.

Darrow, S. L., Vena, J. E., Batt, R. E., Zielezny, M. A., Michalek, A. M. and Selman, S. (1993) Menstrual cycle characteristics and the risk of endometriosis. Epidemiology, 4, 135-142.

Dechaud, H., Witz, C. A., Montoya-Rodriguez, I. A., Degraffenreid, L. A. and Schenken, R. S. (2001) Mesothelial cell-associated hyaluronic acid promotes adhesion of endometrial cells to mesothelium. Fertil Steril, 76, 1012-1018.

D'Hooghe, T. M., Bambra, C. S., Suleman, M. A., Dunselman, G. A., Evers, H. L. and Koninckx, P. R. (1994) Development of a model of retrograde menstruation in baboons (Papio anubis). Fertil Steril, $62,635-638$.

D'Hooghe, T. M., Bambra, C. S., Raeymaekers, B. M., De Jonge, I., Lauweryns, J. M and Koninckx, P. R. (1995) Intrapelvic injection of menstrual endometrium causes endometriosis in baboons (Papio cynocephalus and Papio anubis). Am J Obstet Gynecol, 173, 125-134.

dizeregá, G. S. and Campeau, J. D. (2001) Peritoneal repair and post-surgical adhesion formation. Hum Reprod Update, 7, 547-555.

Dmowski, W. P., Gebel, H. and Braun, D. P. (1998) Decreased apoptosis and sensitivity to macrophage mediated cytolysis of endometrial cells in endometriosis. Hum Reprod Update, 4, 696701 .

Dunselman, G. A., Groothuis, P. G., de Goeij, A. F. and Evers, J. L. (2001) The mesothelium, Teflon or Velcra? Mesothelium in endometriosis pathogenesis. Hum Reprod, 16, 605-607.

Eskenazi, B. and Warner, M. L. (1997) Epidemiology of endometriosis. Obstet Gynecol Clin North Am, 24, 235-258.

Foley-Comer, A. J., Herrick, S. E., Al-Mishlab, T., Prele, C. M., Laurent, G. J. and Mutsaers, S. E. (2002) Evidence for incorporation of free-floating mesothelial cells as a mechanism of serosal healing. I Cell Sci, 115, 1383-1389.

Fotev, Z., Whitaker, D. and Papadimitriou, J. M. (1987) Role of macrophages in mesothelial healing. J Pathol, 151, 209-219.

Fujii, S. (1991) Secondary mullerian system and endometriosis. Am J Obstet Gynecol, 165, 219-225. 
Gabrielson, E. W. Gerwin, B. I., Harris, C. C., Roberts, A. B., Sporn, M. B. and Lechner, J. F. (1988) Stimulation of DNA synthesis in cultured primany human mesothelial cells by specific growth factors. Foseb J, 2, 2717-2721

Groothuis, P. G., Koks, C. A., de Goeij, A. F., Dunselman, G. A., Arends, J. W. and Evers, J. L. (1998a) Adhesion of human endometrium to the epithelial lining and extracellular matrix of amnion in vitro: an electron microscopic study. Hum Reprod, 13, 2275-2281.

Groothuis, P. G., Koks, C. A., de Goeij, A. F., Dunselman, G. A., Arends, J. W. and Evers, J. L. (1998b) Adhesion of human endometrial fragments to peritoneum in vitro. Fertil Steril, $71,1119-1124$.

Groothuis, P. G., Koks, C. A., de Goeij, A. F., Dunselman, G. A., Arends, J. W. and Evers, J. L. (1999) Adhesion of human endometrial fragments to peritoneum in vitro. Fertil Steril, 71, 1119-1124.

Halme, J., Hammond, M. G., Hulka, J. F., Raj, S. G. and Talbert, L. M. (1984) Retrograde menstruation in healthy women and in patients with endometriosis. Obstet Gynecol, 64, 151-154.

Haney, A. F., Muscato, J. J. and Weinberg, J. B. (1981) Peritoneal fluid cell populations in infertility patients. Fertil Steril, 35, 696-698.

Haney, A. F. (1990) Etiology and histogenesis of endometriosis. Prog Clin Biol Res, 323, 1-14

Harada, N., Mizoi, T., Kinouchi, M., Hoshi, K., Ishii, S., Shiiba, K., Sasaki, I. and Matsuno, S. (?001) Introduction of antisense CD44S CDNA down-regulates expression of overall CD44 isoforms and inhibits tumour growth and metastasis in highly metastatic colon carcinoma cells. Int I Cancer, 91, 67.75 .

Hill, J. A. (1997) Immunology and endometriosis. Fact, artifact, or epiphenomenon? Obstet Gynecol Clin North Am, 24, 291-306.

Hofer, S. O., Shrayer, D., Reichner, J. S., Hoekstra, H. J. and Wanebo, H. J. (1998) Wound-induced tumour progression: a probable role in recurrence after tumour resection. Arch Surg, 133, 383-389.

Jenkins, S., Olive, D. L.. and Haney, A. F. (1986) Endometriosis: pathogenetic implications of the anatomic distribution. Obstet Gynecol, 67, 335-338.

Kao, L. C., Germeyer, A., Tulac, S., Lobo, S., YAng, J. P., Taylor, N., Osteen, K., Lessey, B. A. and Ciudice, L. C. (2003) Expression profiling of endometrium from women with endometriosis reveals candidate genes for disease-based implantation failure and infertility. Endocrinology, 144, 28702881 .

Kishikawa, T., Sakamoto, M., Ino, Y., Kubushiro, K., Nozawa, S. and Hirohashi, S. (1995) Two distinct patterns of peritoneal involvement shown by in vitro and in vivo ovarian cancer dissemination models. Invasion Metastosis, 15, 11-21.

Kiyasu, Y., Kaneshima, S. and Koga, S. (1981) Morphogenesis of peritoneal metastasis in human gastric cancer Cancer Res, 41, 1236-1239.

Koks, C. A., Groothuis, P. G., Dunselman, G. A., de Goeij, A. F. and Evers, J. L. (1999) Adhesion of shed menstrual tissue in an in vitro model using amnion and peritoneum: a light and electron microscopic study. Hum Reprod, 14, 816-822.

Koks, C. A., Groothuis, P. G., Dunselman, G. A., de Goeij, A. F. and Evers, 1. L. (2000a) Adhesion of menstrual endometrium to extracellular matrix: the possible role of integrin $\alpha(6) \beta(1)$ and laminin interaction. Mol Hum Reprod, 6, 170-177.

Koks, C. A., Groothuis, P. G., Slaats, P., Dunselman, G. A., de Goeij, A. F. and Evers, J. L. (2000b) Matrix metalloproteinases and their tissue inhibitors in antegradely shed menstruum and peritoneal fluid. Fertil Steril, 73, 604-612.

Koninckx, P. R., Ide, P., Vandenbroucke, W. and Brosens, I. A. (1980) New aspects of the pathophysiology of endometriosis and associated infertility. J Reprod Med, 24, 257-260.

Koninckx, P. R. (1994) is mild endometriosis a condition occurring intermittently in all womer? Hum Reprod, 9, 2202-2205.

Koninckx, P. R., Barlow, D. and Kennedy, S. (1999) Implantation versus infiltration: the Sampson versus the endometriotic theory. Gynecol Obstet Invest, 47, 3-9. 
Kramer, R. H. and Nicolson, G. L. (1979) Interactions of tumour cells with vascular endothelial cell monolayers: a model for metastatic invasion. Proc Natl Acad Sci USA, 76, 5704-5708.

Kruitwagen, R. F., Poels, L. G., Willemsen, W. N., de Ronde, I. J., Jap, P. H. and Rolland, R. (1991) Endometrial epithelial cells in peritoneal fluid during the early follicular phase. Fertil Steril, 55, 297-303.

Kupker, W., Schultze-Mosgau, A. and Diedrich, K. (1998) Paracrine changes in the peritoneal environment of women with endometriosis. Hum Reprod Update, 4, 719-723.

LaRocca, P. J. and Rheinwald, J. G. (1984) Coexpression of simple epithelial keratins and vimentin by human mesothelium and mesothelioma in vivo and in culture. Concer Res, 44, 2991-2999.

Leak, L. V. and Rahil, K. (1978) Permeability of the diaphragmatic mesothelium: the ultrastructural basis for "stomata". Am J Anat, 151, 557-593.

Leavesley, D. I., Stanley, J. M. and Faull, R. J. (1999) Epidermal growth factor modifies the expression and function of extracellular matrix adhesion receptors expressed by peritoneal mesothelial cells from patients on CAPD. Nephrol Dial Transplant, 14, 1208-1216.

Lee, T. L., Yang, M. L. and Bell, P. B., Jr. (1988) Interaction of B 16 malignant melanoma tumour cells with the murine mesentery in vitro. Cancer Res, 48, 5296-5301.

Levander, G. and Normann, P. (1955) The pathogenesis of endometriosis. An experimental study. Acta Obstet Gynecol Scand, 34, 366-398.

Leyendecker, G., Herbertz, M., Kunz, G. and Mall, G. (2002) Endometriosis results from the dislocation of basal endometrium. Hum Reprod, 17, 2725-2736.

Liu, D. T. and Hitchcock, A. (1986) Endometriosis: its association with retrograde menstruation, dysmenorrhoea and tubal pathology. Br J Obstet Gynoecol, 93, 859-862.

Lockwood, C. J., Krikun, G., Hausknecht, V., Wang, E. Y. and Schatz, F. (1997) Decidual cell regulation of hemostasis during implantation and menstruation. Ann N Y Acod Sci, 828, 188-193.

Ludwig, H. and Spornitz, U. M. (1991) Microarchitecture of the human endometrium by scanning electron microscopy: menstrual desquamation and remodeling. Ann N Y Acad Sci, 622, 28-46.

Maas, J. W., Groothuis, P. G., Dunselman, G. A., de Goeij, A. F., Struyker Boudier, H. A. and Evers, J. L. (2001) Endometrial angiogenesis throughout the human menstrual cycle. Hum Reprod, 16, 1557-1561.

Malinak, L. R., Buttram, V. C., Jr., Elias, S. and Simpson, J. L. (1980) Heritage aspects of endometriosis. II. Clinical characteristics of familial endometriosis. Am J Obstet Gynecol, 137, 332337.

Markee, J. E. (1946) Menstruation in intraocular endometrial transplants in the rhesus monkeys. $J$ Am Med Assoc, 250, 2167-2171.

Marshali, B. C., Santana, A., Xu, Q. P., Petersen, M. J., Campbell, E. J., Hoidal, J. R. and Welgus, H. G. (1993) Metalloproteinases and tissue inhibitor of metalloproteinases in mesothelial cells. Cellular differentiation influences expression. J Clin Invest, 91, 1792-1799.

Merrill, J. A. (1966) Endometrial induction of endometriosis across Millipore filters. Am J Obstet Gynecol, 94, 780-790.

Michailova, K., Wassilev, W. and Wedel, T. (1999) Scanning and transmission electron microscopic study of visceral and parietal peritoneal regions in the rat. Anot Anz, 181, 253-260.

Miura, T., Shimada, T., Tanaka, K., Chujo, M. and Uchida, Y. (2000) Lymphatic drainage of carbon particles injected into the pleura! cavity of the monkey, as studied by video-assisted thoracoscopy and electron microscopy. I Thorac Cardiovasc Surg, 120,437-447.

Mutsaers, S. E., Bishop, 1. E., McGrouther, G. and Laurent, G. J. (1997) Mechanisms of tissue repair: from wound healing to fibrosis. Int J Biochem Cell Biol, 29, 5-17.

Mutsaers, S. E., Whitaker, D. and Papadimitriou, J. M. (2000) Mesothelial regeneration is not dependent on subserosal cells. J Pathol, 190, 86-92.

Mutsaers, 5. E. (2002) Mesothelial cells: theif structure, function and role in serosal repair. Respirology, 7, 171-191. 
Mutsaers, S. E., Whitaker, D. and Papadimitriou, J. M. (2002) Stimulation of mesothelial cell proliferation by exudate macrophages enhances serosal wound healing in a murine model. Am J Pothol, $160,681-692$.

Nakashio, T., Narita, T., Akiyama, S., Kasai, Y., Kondo, K., Ito, K., Takagi, H. and Kannagi, R. (1997) Adhesion molecules and TGF- $\beta 1$ are involved in the peritoneal dissemination of NUGC-4. human gastric cancer cells. Int I Concer, 70, 612-618.

Nap, A. W., Groothuis, P. G., Demir, A. Y., Maas, J. W., Dunselman, G. A., de Goeij, A. F. and Evers, J. L. (2003) Tissue integrity is essential for ectopic implantation of human endometrium in the chicken chorioallantoic membrane. Hum Reprod, 18, 30-34.

Niedbala, M. J., Crickard, K. and Bernacki, R. J. (1985) Interactions of human ovarian tumour cells with human mesothelial cells grown on extracellular matrix. An in vitro model system for studying tumour cell adhesion and invasion. Exp Cell Res, 160, 499-513.

Nisolle, M. and Donnez, J. (1997) Peritoneal endometriosis, ovarian endometriosis, and adenomyotic nodules of the rectovaginal septum are three different entities. Fertil Steril, 68, 585-596.

Ohtake, H., Katabuchi, H., Matsuura, K. and Okamura, H. (1999) A novel in vitro experimental model for ovarian endometriosis: the three-dimensional culture of human ovarian surface epithelial cells in collagen gels. Fertil Steril, 71, 50-55.

Olive, D. L. and Henderson, D. Y. (1987) Endometriosis and mullerian anomalies. Obstet Gynecol, $69,412-415$.

Pelin, K., Hirvonen, A. and Linnainmaa, K. (1994) Expression of cell adhesion molecules and connexins in gap junctional intercellular communication deficient human mesothelioma tumour cell lines and communication competent primary mesothelial cells. Carcinogenesis, 15, 2673-2675.

Redwine, D. B. (1990) The visual appearance of endometriosis and its impact on our concepts of disease. Prog Clin Biol Res, 323, 393-412.

Reymond, M. A., Schneider, C., Kastl, S., Hohenberger, W. and Kockerling, F. (1998) The pathogenesis of port-site recurrences. I Gostrointest Surg, 2, 406-414.

Rovensky, Y. A., Gvichiya, A. S. and Vasiliev, J. M. (1980) SEM study of the attachment of mouse ascitic hepatoma cells to various substrata. Scan Electron Microsc, 3, 71-78.

Salamonsen, L. A. and Lathbury, L. J. (2000) Endometrial leukocytes and menstruation. Hum Reprod Update, 6, 16-27.

Sampson, J. A. (1927) Peritoneal endometriosis due to menstrual dissemination of endometrial tissue into the peritoneal cavity. Am J Obstet Cynecol, 14, 422-469.

Sanfilippo, J. S., Wakim, N. G., Schikler, K. N. and Yussman, M. A. (1986) Endometriosis in association with uterine anomaly. Am J Obstet Gynecol, 154, 39-43.

Santanam, N., Murphy, A. A and Parthasarathy, S. (2002) Macrophages, oxidation and endometriosis. Ann N Y Acod Sci, 955, 183-198.

Schenken, R. S. (1989) Pathogenesis In "Endometriosis, contempary concepts in clinical management" (Schenken, R. S., ed.), pp. 1-49. J. B. Lippincott Co, Philadelphia.

Schlaeppi, M., Ruegg, C., Tran-Thang, C., Chapuis, G., Tevaearai, H., Lahm, H. and Sordat, B. (1997) Role of integrins and evidence for two distinct mechanisms mediating human colorectal carcinoma cell interaction with peritoneal mesothelial cells and extracellular matrix. Cell Adhes Commun, 4, 439-455.

Sharpe-Timms, K. L. (2001) Endometrial anomalies in women with endometriosis. Ann N Y Acad Sci, $943,131-147$.

Sillem, M., Hahn, U., Coddington, C. C., 3rd, Gordon, K., Runnebaum, B. and Hodgen, G. D. (1996) Ectopic growth of endometrium depends on its structural integrity and proteolytic activity in the cynomolgus monkey (Macaca fascicularis) model of endometriosi.s. Fertil Steril, 66, 468-473.

Simpson, J. L., Elias, S., Malinak, L. R. and Buttram, V. C., Jr. (1980) Heritable aspects of endometriosis. I. Cenetic studies. Am J Obstet Gynecol, 137, 327-331. 
Sugarbaker, P. H., Cunliffe, W. J., Belliveau, J., de Bruijn, E. A., Graves, T., Mullins, R. E. and Schlag, P. (1989) Rationale for integrating early postoperative intraperitoneal chemotherapy into the surgical treatment of gastrointestinal cancer. Semin Oncol, 16, 83-97.

Suginami, H. (1991) A reappraisal of the coelomic metaplasia theory by reviewing endometriosis occurring in unusual sites and instances. Am J Obstet Gynecol, 165, 214-2 18.

Tabibzadeh, S. (1996) The signais and molecular pathways involved in human menstruation, a unique process of tissue destruction and remodeling. Mol Hum Reprod, 2, 77-92.

Te Linde, R. W. and Scott, R. B. (1950) Experimental endometriosis. Am J Obstet Cynecol, 60, $1147-1173$.

van den Tol, P. M., van Rossen, E. E., van Eijck, C. H., Bonthuis, F., Marquet, R. L. and Jeekel, H. (1998) Reduction of peritoneal trauma by using nonsurgical gauze leads to less implantation metastasis of spilled tumour cells. Ann Surg, 227, 242-248.

van der Linden, P. J., Dunselman, G. A., de Goeij, A. F., van der Linden, E. P., Evers, J. L. and Ramaekers, F. C. (1995) Epithelial cells in peritoneal fluid-of endometrial origin? Am J Obstet Gynecol, 173, 566-570.

van der Linden, P. J., de Goeij, A. F., Dunselman, G. A., Erkens, H. W. and Evers, J. L. (1996) Endometrial cell adhesion in an in vitro model using intact amniotic membranes. Fertil Steril, 65, 7680.

Van Muijen, G. N., Ruiter, D. J. and Warnaar, S. O. (1987) Coexpression of intermediate filament polypeptides in human fetal and adult tissues. Lab Invest, 57, 359-369.

van Rossen, M. E., Hofland, L. J., van den Tol, M. P., van Koetsveld, P. M., Jeekel, J., Marquet, R. L. and van Eijck, C. H. (2001) Effect of inflammatory cytokines and growth factors on tumour cell adhesion to the peritoneum. J Pathol, 193, 530-537.

Warn, R., Harvey, P., Warn, A., Foley-Comer, A., Heldin, P., Versnel, M., Arakaki, N., Daikuhara, Y., Laurent, G. J., Herrick, S. E, et al. (2001) HCF/SF induces mesothelial cell migration and proliferation by autocrine and paracrine pathways. Exp Cell Res, 267, 258-266.

Whitaker, D., Papadimitriou, J. M. and Walters, M. N. (1982) The mesothelium and its reactions: a review. Crit Rev Toxicol, 10, 81-144.

Whitaker, D. and Papadimitriou, J. (1985) Mesothelial healing: morphological and kinetic investigations. J Pothol, 145, 159-175.

Witz, C. A., Monotoya-Rodriguez, I. A. and Schenken, R. 5. (1999) Whole explants of peritoneum and endometrium: a novel model of the early endometriosis lesion. Fertil Steril, 71, 56-60.

Witz, C. A., Thomas, M. R., Montoya-Rodriguez, I. A., Nair, A. S., Centonze, V. E. and Schenken, R. S. (2001) Short-term culture of peritoneum explants confirms attachment of endometrium to intact peritoneal mesothelium. Fertil Steril, 75, 385-390.

Zeitoun, K. M. and Bulun, S. E. (1999) Aromatase: a key molecule in the pathophysiology of endometriosis and a therapeutic target. Fertil Steril, 72, 961-969. 


\section{[ Chapter 2$]$}

Scope of the thesis 
Chapter 2 
To date, although the exact pathogenesis of endometriosis is not well understood, the retrograde menstruation and transplantation theory is widely accepted. However, the molecular events that take place during the development of peritoneal endometriosis from retrogradely shed menstrual endometrium are not clearly defined. A major debate in this regard concerns the dialogue between shed menstrual endometrium and the mesothelial lining of the peritoneum. Previous adhesion studies using peritoneum and endometrium from all phases of the cycle have shown that endometrial fragments adhere where the epithelial layer of the peritoneum is damaged. Whether these denuded surfaces were already existent or created by the endometrial tissue itself was not clear. It is known that tumour cells or ascites induce changes in mesothelial cell morphology and cause damage to the mesothelial lining. Based on these findings we hypothesize that shed menstrual endometrium is capable to disrupt the intact mesothelial lining facilitating the adhesion of endometrium fragments on the peritoneal surfaces and hence the development of endometriosis. The overall objective of this thesis is to explore the effects of shed menstrual endometrium on the cells of the mesothelial lining at the cellular and subcellular level.

Since retrogradely shed menstrual endometrium can not be collected for practical reasons in the human in sufficient amounts, anterogradely shed menstrual endometrium (menstrual effluent) collected with a vaginal cup was used as a source of retrogradely shed menstrual endometrium. Since human peritoneum is easily damaged during recovery either by laparoscopy or by laparotomy, monolayers of mesothelial cells recovered from human omentum were used, to mimic the mesothelial lining of the peritoneum.

The first aim of the thesis is therefore to investigate the potential detrimental effect of the menstrual effluent components on the mesothelial cell monolayer. The results, which illustrate morphological changes in mesothelial cells induced by menstrual effluent, are presented in Chapter 3.

The alterations induced by menstrual effluent as observed in mesothelial ceils closely resemble morphological changes during cell death, apoptosis or necrosis, or during cellular remodeling. Therefore, these processes were studied at the molecular and morphological level in mesothelial cells. The results are presented in Chapter 4.

Since the morphological changes were shown not to be primarily related to apoptosis or necrosis, cellular remodeling seems to be involved. In Chapter 5 evidence is presented that the observed morphological alterations in mesothelial cells are epithelial to mesenchymal transitions. The signal transduction pathways possibly involved are discussed.

Functional changes in cellular proteins determine the epithelial to mesenchymal transitions. The fourth aim of the thesis is to assess and identify the proteins that are differentially expressed and phosphorylated during this process using a proteomic approach. Results are presented in Chapter 6.

Soluble factors which are present in shed menstrual effluent induce epithelial to mesenchymal transitions in mesothelial cells. Molecular identification of these soluble factors was attempted and is described in Chapter 7. 
Chapter 2

In Chapter 8 the results and conclusions of these studies are discussed and several future perspectives are outlined. 


\section{Chapter 3 ]}

\section{Menstruum induces changes in mesothelial cell morphology}

C.A.M. Koks'

A.Y. Demir Weusten ${ }^{3}$

P.G. Groothuis ${ }^{1.3}$

G.A.J. Dunselman ${ }^{13}$

A.F.P.M. de Goeij ',2

J.L.H. Evers ${ }^{1.3}$

Departments of 'Obstetrics \& Gynaecology and 'Pathology, 'Research Institute Growth and Development (GROW), Academisch ziekenhuis Moastricht and Maastricht University, P.O. Box 5800, 6202 AZ Maastricht, The Netherlands

Gynecol Obstet Invest, 2000; 50,13-18

Modified from the original manuscript 
Chapter 2 


\section{Abstract}

In previous studies, we have shown that menstrual endometrium preferentially adheres to the subepithelial lining of the peritoneum. It remains to be elucidated, however, whether this damage was pre-existing or inflicted by the menstrual tissue itself. We hypothesized that the menstrual tissue itself damages the peritoneum. To investigate this, the viability of menstrual endometrial tissue in peritoneal fluid was evaluated and the morphological changes in the mesothelial cells were studied by in vitro cocultures of menstruum with mesothelial cell monolayers. Menstruum was collected with a menstrual cup. Endometrial tissue was isolated from the menstruum, resuspended in culture medium or in the cellfree fraction of peritoneal fluid and cultured for 24,48 or 72 hours. A 3(4,5-dimethylthiazolyl-2)-2,5diphenyl tetrazolium bromide (MTT) assay was performed to obtain a relative measure of viable adhered endometrial cells. Mesothelial cells isolated from human omental tissue were cultured on Matrigel or uncoated plastic. At confluence, overnight cocultures were performed and scanning electron microscopy was used to evaluate the morphological changes.

The viability of endometrial fragments was $84 \%(n=36, p<0.05), 82 \%(n=27$, not significant) and 104\% ( $n=14$, not significant) when cultured in the cell-free fraction of peritoneal fluid for 24,48 and 72 hours, respectively, when compared to medium with $10 \%$ fetal calf serum. Menstrual endometrial fragments or menstrual serum added to and cocultured with mesothelial cells induced severe morphologic alterations of the latter, including retraction, shrinking and gap formation. Similar morphologic changes were observed when mesothelial cells were cocultured with menstrual endometrial fragments in peritoneal fluid or in culture inserts. Incubation with conditioned medium from cultured menstrual endometrium induced similar but less pronounced changes in morphology.

In conclusion, menstrual endometrium fragments remain viable in peritoneal fluid in vitro for at least 72 hours. Anterogradely shed menstruum induces changes in mesothelial cell morphology, including retraction and shrinking with exposure of the underlying surface. These findings suggest that menstruum is harmful to the peritoneal lining. Therefore, by local destruction of the mesothelial layer menstrual endometrium is able to create sites for adhesion. 


\section{Introduction}

According to Sampson (Sampson, 1940), the adhesion of retrogradely shed endometrium to the peritoneal lining is conceivably an important step in the pathogenesis of endometriosis. In previous in vitro studies, we have demonstrated that cyclic endometrium and menstrual endometrial fragments preferentially adhere to extracellular matrix components of damaged amnion and peritoneum, but not to intact epithelium lining (Groothuis et al., 1998; Koks et al., 1999). It is tempting to suggest that the menstrual tissue itself, after arrival in the peritoneal cavity, is the cause of the exposure of the extracellular matrix. From cancer studies it is known that tumour cells injected intra-abdominally induce morphologic changes in the mesothelial cells, resulting in exposure of the basement membrane between adjoining cells (Buck, 1973).

Cellular and biochemical constituents of the peritoneal fluid have been postulated to play an important role in the pathogenesis of endometriosis. Peritoneal fluid contains growth factors that may be involved in the implantation and the maintenance of the ectopic endometrium (Ramey and Archer, 1993).

In the present study, we investigated whether menstrual endometrium remains viable in peritoneal fluid for a period of time. We also determined whether the peritoneal lining is susceptible to damage inflicted by menstrual tissue, and whether this putative injury requires the physical presence of menstrual endometrium.

To this end, mesothelial cell monolayers were cocultured with various constituents of menstruum and morphological changes were analysed using scanning electron microscopy.

\section{Materials and Methods}

\section{Characteristics of volunteers}

All 8 volunteers had regular ovulatory cycles varying from 25 to 34 days with 4-7 days of blood loss. None of them used oral contraceptives or intrauterine copper device. Their mean age was 34 years (range 21-44). All gave written, informed consent. The institutional review board and the medical ethics committee approved the study protocol.

\section{Menstrual fluid collection}

Menstrual fluid was collected with a menstrual cup for 2-3 hours during the first and second day of the menstrual period. Day 1 was defined as the 24 hours from the first awareness of menstrual bleeding onwards. The menstrual cup was a soft natural rubber cup ("Keeper", Den Haag, The Netherlands), a device that was used in our previous 
studies (Koks et al., 1997; Koks et al., 1999). After collection, the menstrual fluid was transferred directly into a plastic container and delivered to the laboratory immediately.

\section{Isolation of menstrual endometrial tissue}

Endometrial tissue was obtained by the method described previously (Koks et al., 1997). Briefly, menstrual fluid samples were centrifuged at $1167 \mathrm{~g}$ for 10 minutes. The supernatant (serum) was isolated and used for coculture with mesothelial cells, or immediately snapfrozen in isopentane immersed in dry ice and stored at $-20^{\circ} \mathrm{C}$ until use. The pellet was resuspended in complete culture medium consisting of Dulbecco's modified Eagle's medium/Ham's F-12 (Life Technologies BV, Breda, The Netherlands) supplemented with 10\% fetal calf serum (FCS), $2 \mathrm{mM} \mathrm{L-glutamine} \mathrm{and} 100 \mathrm{IU} / \mathrm{ml}$ penicillin and $100 \mu \mathrm{g} / \mathrm{ml}$ streptomycin (Life Technologies) and layered on a HistoPaque 1077 (Sigma-Aldrich Chemie B.V.) gradient to remove red blood cells. After centrifugation for 5 minutes at $1167 \mathrm{~g}$ menstrual tissue was collected from the interface, washed once, resuspended in complete culture medium and filtered through a $100 \mu \mathrm{m}$ nylon filter (Micronic, Lelystad, The Netherlands) and a $30 \mu \mathrm{m}$ polyamide filter (Stokvis \& Smits, ljmuiden, The Netherlands). The menstrual endometrial fragments retained on the 100 and $30 \mu \mathrm{m}$ filters were resuspended in complete culture medium. The suspension filtered through the $30 \mu \mathrm{m}$ filter was layered on a HistoPaque 1077 gradient to remove red blood cells and to obtain small tissue fragments and single cells.

\section{Preparation of conditioned medium}

The menstrual endometrial fragments from 4 volunteers which were retained on the 100 and $30 \mu \mathrm{m}$ filters were pooled with the fragments $<30 \mu \mathrm{m}$ and cultured in plastic Petri dishes with $5 \mathrm{ml}$ of complete culture medium. After culturing for 24 hours, the medium was collected, centrifuged and the supernatant was immediately frozen in isopentane immersed in dry ice and stored at $-80^{\circ} \mathrm{C}$ until use.

\section{Mesothelial cell isolation and culture}

Two volunteers undergoing benign laparotomic operations donated omental tissue after giving informed consent. Human mesothelial cells were isolated from freshly obtained omental fat tissue according to a previously described method (van Hinsbergh et al., 1990), with minor modifications. The omental tissue was collected and immediately transported to the laboratory. The tissue was rinsed, minced and incubated with phosphatebuffered saline (PBS) containing collagenase $(2 \mathrm{mg} / \mathrm{ml})$, glucose (3 $\mathrm{mM}$ ) and bovine serum albumine (4\%) for 15 minutes at $37^{\circ} \mathrm{C}$. After incubation, the suspension was sieved through a $400 \mu \mathrm{m}$ filter and centrifuged at $30 \mathrm{~g}$ for 10 minutes. Floating fat cells were carefully removed by aspiration and the suspension was centrifuged for 10 minutes at 
$605 \mathrm{~g}$. The obtained pellet was resuspended in complete culture medium and sieved through a $30 \mu \mathrm{m}$ filter. The clumps of mesothelial cells on the filter were resuspended in the same medium and centrifuged. The obtained pellet was resuspended in $5 \mathrm{ml}$ of complete culture medium containing 1\% FCS and this was layered on $40 \mathrm{ml}$ of PBS containing $\mathrm{CaCl}_{2}(0.1 \mathrm{mg} / \mathrm{ml})$ and bovine serum albumin (5\%). After 10 minutes, the upper $10 \mathrm{ml}$ was discarded and the rest was centrifuged and resuspended in complete culture medium containing 20\% FCS, $2 \mathrm{mM} \mathrm{L-glutamine,} 100 \mathrm{IU} / \mathrm{ml}$ penicillin and $100 \mathrm{\mu g} / \mathrm{ml}$ streptomycin and the mesothelial cells were seeded on fibronectin-coated dishes. Cells were cultured at $37^{\circ} \mathrm{C}$ and the culture medium was changed every 2-3 days. When the cells reached confluency, they were tyripsinized and passaged with a split ratio 1:2. Mesothelial cells from passage one or two were used for the experiments. Mesothelial cells were cultured on Thermanox Coverslips (ICN, Ohio, USA). Part of the coverslips was coated with Matrigel (Collaborative Research, Bedford, Mass., USA) and the other part was uncoated. After reaching confluence, the cocultures were started.

\section{Collection of peritoneal fluid}

Peritoneal fluid samples $(n=15)$ were obtained from women undergoing diagnostic laparoscopy for infertility work up or sterilization. Informed consent forms were signed by each woman prior to surgery. All the women had ovulatory cycles, as confirmed by ultrasound and/or an adequate rise in serum progesterone in the luteal phase of the cycle. Peritoneal fluid was collected immediately after introduction of the second trocar. The obtained fluid was transported to the laboratory on ice and immediately centrifuged for 3 minutes. The pellet was discarded, and the supernatant was divided into small aliquots and snap-frozen in isopentane in dry ice. The peritoneal fluid samples were stored at $.80^{\circ} \mathrm{C}$ until use.

\section{Identification of cell type}

Immunohistochemical characterization of menstrual endometrial tissue has been reported in a previous study (Koks et al., 1997). Cytospin preparations of mesothelial cells were stained with monoclonal antibodies against the intermediate filaments (vimentin and cytokeratin), endothelial cells (CD34) and endometrial epithelial cells (BW495/36). Human endometrial tissue and human umbilical cord, respectively, were used as controls.

\section{Cultures of menstrual endometrial fragments in peritoneal fluid}

Menstrual endometrial fragments retained on the 100 um filter were collected and divided into 4-8 equal parts, depending on the amount of tissue obtained. For each experiment $(n=36)$, the tissue was seeded onto one of four coatings; collagen I (Sanver Tech, 
Heerhugowaard, The Netherlands), collagen IV (Sigma Bioscience, St Louis, USA), laminin (ICN) or fibronectin (Sanver Tech). Half of the fragments were cultured in complete culture medium and the other half was cultured in the cell-free fraction of peritoneal fluid for 24 hours. In further experiments, the tissue retained on the $100 \mu \mathrm{m}$ filter was cultured on Matrigel either in complete culture medium or in peritoneal fluid for 48 or 72 hours.

\section{MTT-assay}

To quantitate viable cells a 3(4,5-dimethylthiazolyl-2)-2,5-diphenyl-2H-tetrazolium bromide (MTT) assay was performed. After discarding complete culture medium or peritoneal fluid, the plates were rinsed once with complete culture medium. Then $200 \mu \mathrm{l}$ of complete culture medium was added to each well, together with $30 \mu \mathrm{l}$ of MTT solution $(5 \mathrm{mg} / \mathrm{ml}$ ). MTT is reduced by viable cells to a coloured, water-insoluble formazan salt. After incubation for 4 hours at $37^{\circ} \mathrm{C}$ the supernatant was discarded and the formazan salt was dissolved in $100 \mu \mathrm{l}$ of dimethyl sulfoxide. Measuring the optical density at $540 \mathrm{~nm}$ quantitated the amount of formazan formed.

\section{Coculture studies}

Nine experiments were performed with different coculture combinations. Incubations were performed overnight at $37^{\circ} \mathrm{C}$. These different cocultures were performed simultaneously. In all experiments, a monolayer of mesothelial cells was included as a control $(n=9)$. Endometrial fragments retained on the 100 and $30 \mu \mathrm{m}$ filters were pooled and either layered directly onto the monolayer in complete culture medium $(n=7)$ or in peritoneal fluid $(n=2)$, or in a Transwell insert (Millipore, Bedford, Mass., USA) ( $n=5)$. Five mesothelial monolayers were incubated with conditioned medium of cultured menstrual endometrium. One monolayer was incubated with endometrial fragments enzymatically prepared from secretory endometrium (cd 22).

The monolayers of endothelial cells from human umbilical cord (HUVEC) wert: cultured on gelatin-coated $\left(0.2 \%\right.$ gelatin, 30 minutes, $\left.37^{\circ} \mathrm{C}\right)$ plates in RPMI 1640 supplemented with $15 \%$ human serum, $2 \mathrm{mM} \mathrm{L-glutamine,} 100 \mathrm{IU} / \mathrm{ml}$ penicillin and $100 \mu \mathrm{g} / \mathrm{ml}$ streptomycin (all from Life Technologies). When the cells were confluent, menstrual serum $(10 \%)$ was added to the culture medium. The effect of menstrual serum (10\%) was also tested on the monolayers of human endometrium carcinoma cell-line (ECC-1 cells) that were cultured on uncoated plates in complete culture medium.

\section{Scanning electron microscopy}

After incubation overnight, the coverslips were rinsed in PBS and fixed in 2.5\% glutaraldehyde in phosphate buffer $(\mathrm{pH}$ 7.4). Following fixation, the samples were dehydrated in 
a graded series of alcohol, critical point dried, sputtered with gold and examined under a Philips 505 scanning electron microscope (Philips, Eindhoven, The Netherlands).

\section{Statistical analysis}

The Wilcoxon matched-pairs signed-rank test was used for statistical analysis. Significance was set at $p<0.05$.

\section{Results}

When the viability, referred to as the percentage of viable cells, of cultured menstrual endometrial cells in complete culture medium with 10\% FCS was set at 100\%, the viability in peritoneal fluid was $84 \%(p<0.05, n=36)$ when cultured on different coatings during 24 hours (Figure 1). The significant difference was due to a reduction in the number of cells when cultured on laminin (Figure 1).

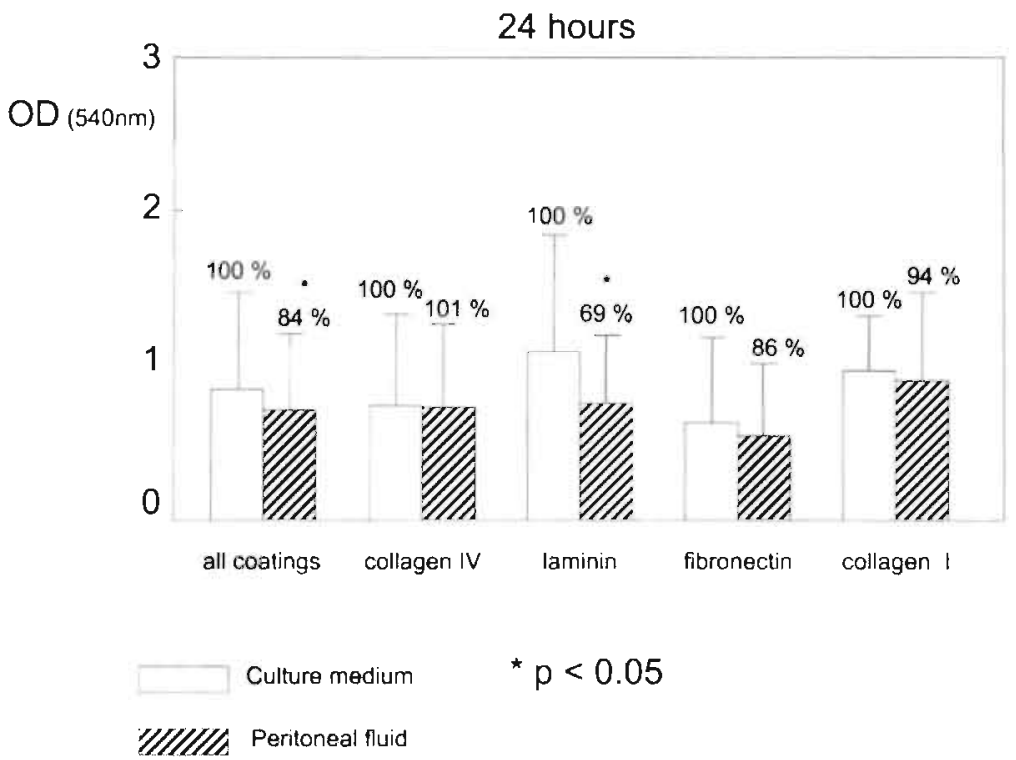

Figure 1: Viability of menstrual endometrial fragments cultured for 24 , hours on collogen I, collagen $N$, laminin and fibronectin, and incubated either in complete culture medium or in peritoneal fluid.

When cultured on matrigel for 48 or 72 hours, the viability of endometrial fragments cultured in peritoneal fluid was $82 \%$ (not significant, $n=27$ ) and 104\% (not significant, $n=14$ ), as compared to $100 \%$ in complete culture medium with $10 \%$ FCS (Figure 2). 


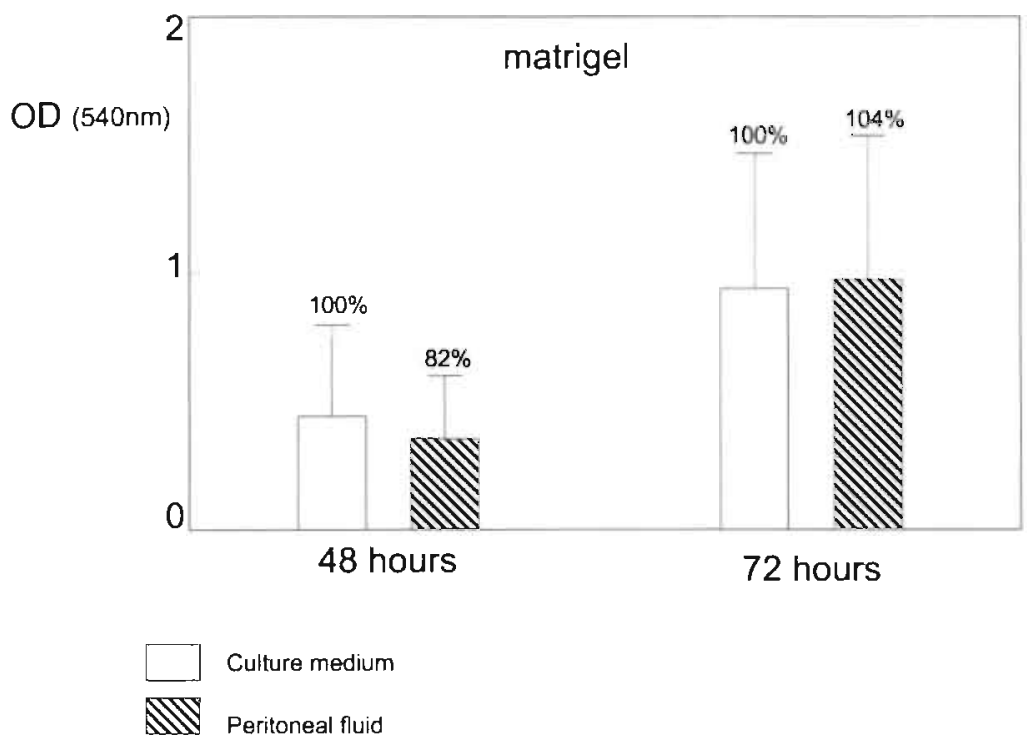

Figure 2: Viability of menstrual endometrial fragments cultured for 48 and 72 hours on matrigel and incubated either in complete culture medium or in peritoneal fluid.

The obtained mesothelial cells used for the cocultures exhibited strong immunocytochemical reactivity to antibodies against cytokeratin and vimentin, but were negative for antibodies to the endometrial epithelial marker (BW495/36) and CD34, the marker for endothelium.

When cultured on plastic or Matrigel with complete culture medium containing 10\% FCS, mesothelial cells were flat and polygonal with prominent nucleoli. After reaching confluency, they had a 'cobbelstone' pattern as seen with light microscopy.

Scanning electron microscopy revealed numerous microvilli on the cell surface as well as intercellular junctions (Figure 3A). Coculturing endometrial fragments isolated from menstrual effluent, directly or separated by an insert, changed the morphology of the mesothelial cells. The shape of the cells changed to a more wispy appearance, leaving intercellular spaces between them (Figures $3 B \& 3 C$ ). A similar reaction was seen when the mesothelial cells were cocultured with menstrual serum or with menstrual endometrium fragments and peritoneal fluid together (Figures $3 D \& 3 E$ ). Conditioned medium also induced morphological changes in the mesothelial cells, but to a lesser extent (Figure 3F). Coculture with fragments prepared from secretory endometrium induced no morphologic alterations in the mesothelial cells (Figures $3 G \& 3 H$ ). When HUVEC were cultured in menstrual serum, they acquired a fibroblastic form (Figures $4 A \& 4 B$ ), whereas the ECC-1 cells showed a slight shrinkage (Figures 4C \& 4D). 

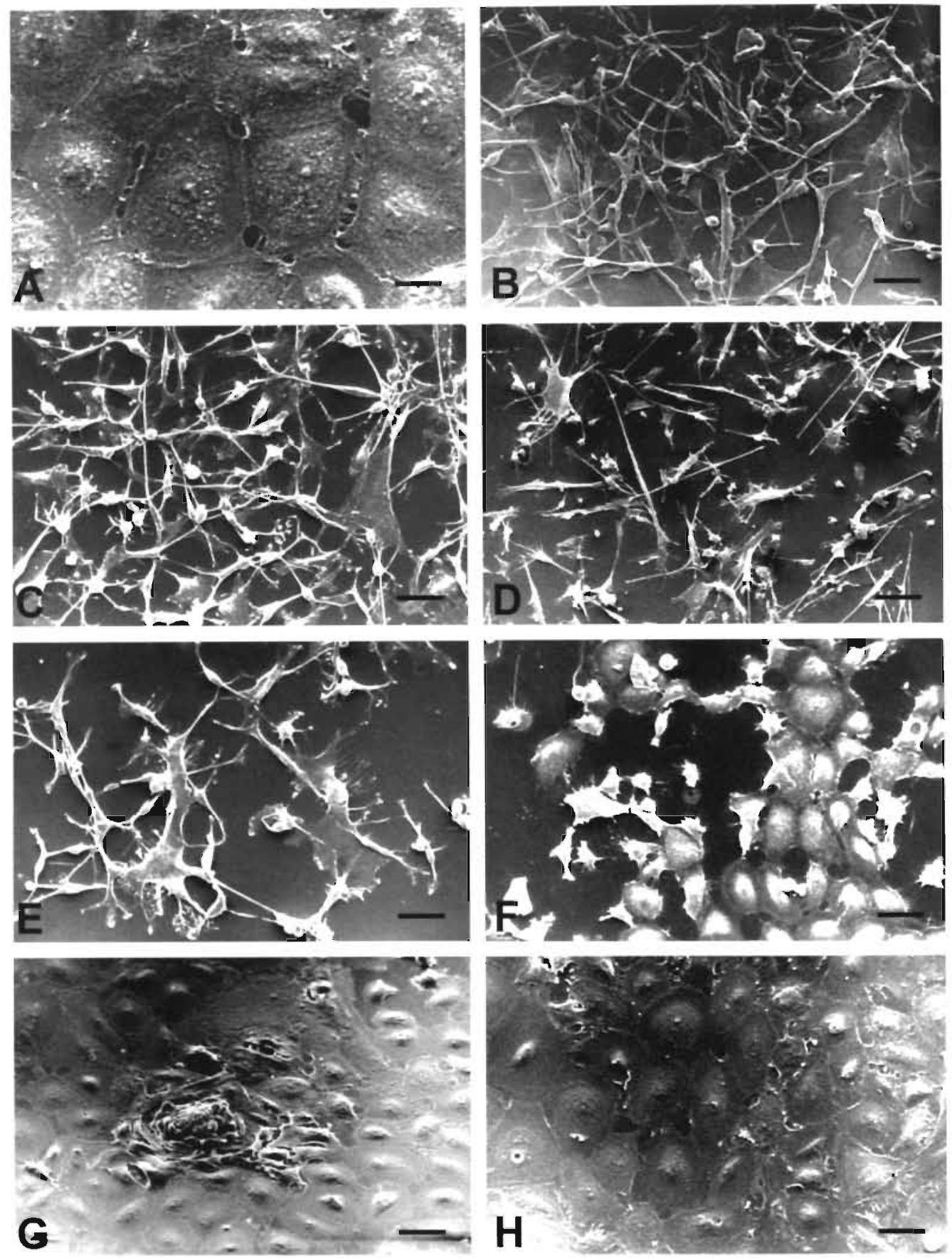

Figure 3: Scanning electron micrographs of cocultures of mesothelial cell monolayers with complete culture medium (A), menstrual endometriai frogments directly layered $(B)$, menstrual endometrial fragments in an insert (C), menstrual serum (D), menstrual endometrial fragments in peritoneal fluid (E), 
conditioned medium $(F)$ and fragments from secretory endometrium $(C, H)$. Scale bars represent 10 $\mu m(A), 25 \mu m(B, C, E-H)$.
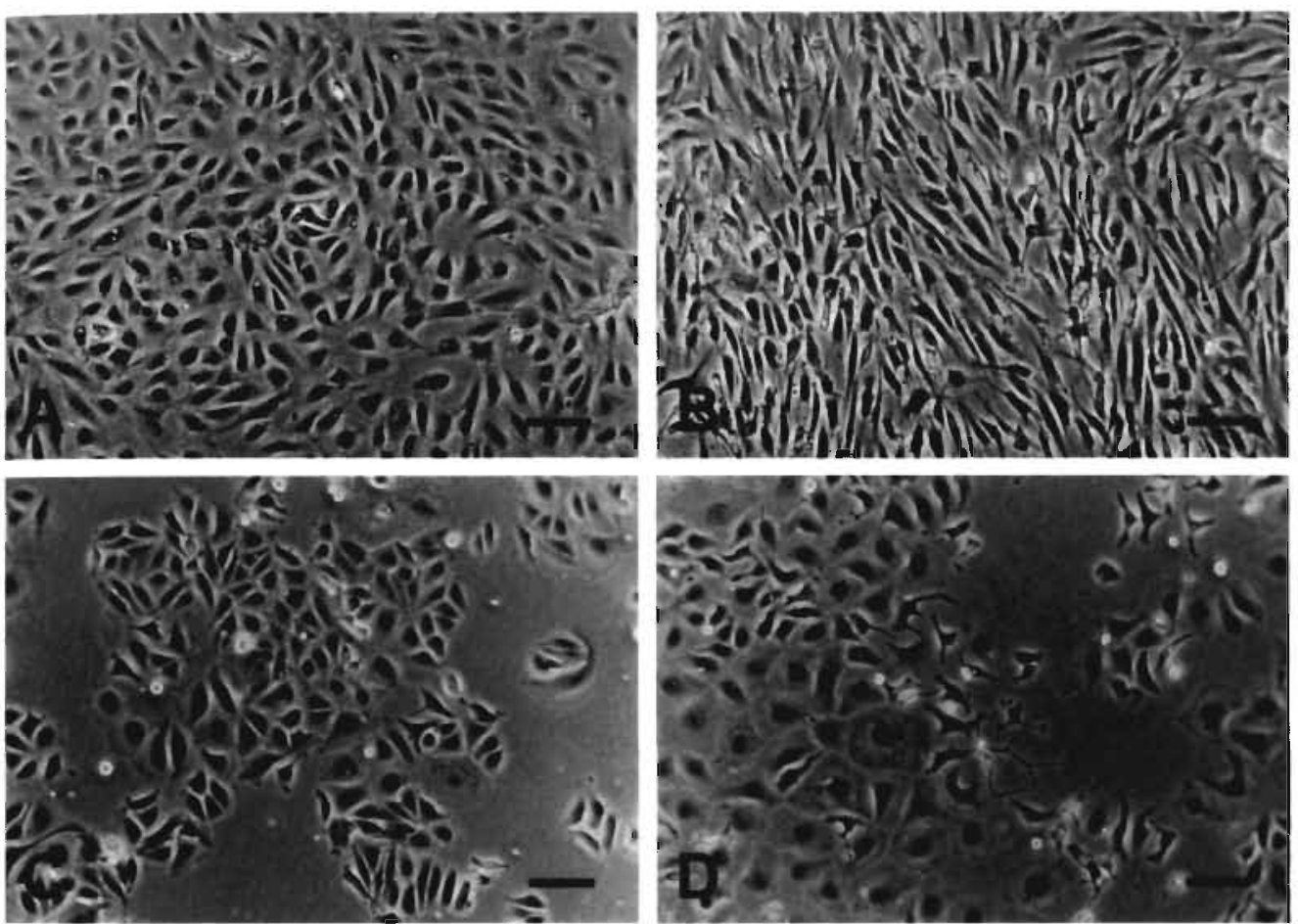

Figure 4: Light micrographs of cocultures of HUVEC (A\&B) and ECC-1 cells ( $C \& D)$ in culture medium supplemented with ( $B \& D$ ) and without menstrual serum ( $A$ \& $C$ ). Scale bars represent $100 \mu \mathrm{m}$.

\section{Discussion}

We have shown in this study that menstrual endometrial fragments remain viable in peritoneal fluid for at least 72 hours. This menstrual tissue is able to adhere to various different components of the extracellular matrix, such as laminin, fibronectin, collagen I and IV. Several other studies have focussed on the effect of peritoneal fluid on endometrial cell viability and proliferation (Surrey and Halme, 1990; Koutsilieris et al., 1991; Overton et al., 1997). However, in these studies the proliferative effect of peritoneal fluid from women with and without endometriosis was tested on stromal cells of cyclic and not menstrual endometrium. 
The potential harmful effect of various tumour and inflammation-related cells on mesothelial cells, upon intraperitoneal injection in vivo and in coculture experiments in vitro, has been described extensively (Buck, 1973; Niedbala et al., 1985; Andreoli et al., 1994; Yashiro et al., 1996). Usually, intercellular junctions between mesothelial cells were disrupted, resulting in retraction, exfoliation and subsequent exposure of the underlying basement membrane. In this study, we demonstrate that naturally shed endometrium isolated from menstrual effluent is able to induce changes in mesothelial cell monolayers similar to those induced by tumour cells. By incubating mesothelial cell monolayers with the various constituents of menstrual effluent and conditioned medium from cultures of menstrual endornetrium, and by coculturing the mesothelial monolayer with menstrual endometrium in culture inserts, we were able to demonstrate that the observed effects are most likely mediated in a paracrine fashion, although direct effect may also occur. The observed effects on mesothelial cells seem to be specific for shed endometrium, since coculture with endometrial fragments isolated from secretory endometrium did not induce morphologic changes in the mesothelial cells. This might well be the consequence of the pre-treatment of secretory endometrium with trypsin, which is able to inactivate factors causing morphological changes. The effects of menstrual serum, which were observed in the monolayers of HUVEC and ECC-1 cells, imply that the morphologic changes are specific to epithelial-like cells.

Interactions such as proliferation and adhesion between endometrium and mesothelial cells have been investigated in other studies (Sharpe et al., 1992; Zhang et al., 1993; Wild et ol., 1994). Although not a subject of investigation, these groups reported no morphologic changes in mesothelial cells. The differences maybe due to several factors: (1) the endometrium used was pre-treated enzymatically; (2) it was not menstrual endometrium, or (3) it was non-human material. We want to stress here that investigations into the pathogenesis of endometriosis should take into account the fact that menstrual endometrium differs from enzymatically prepared proliferative and secretory endometrium, and from isolated stromal and epithelial cells. For example, the expression of several matrix metalloproteinases, cytokines and growth factors in endometrium are increased during menstruation (Tabibzadeh, 1996).

Paracrine efte'cts of menstrual endometrium on mesothelial cells may facilitate the implantation of ectopic endometrial tissue in the peritoneal cavity. However the factor(s) released by menstrual endometrium which induce the observed morphological changes as well as the possible functional changes of mesothelial cells remain to be determined.

Another interesting observation was the large variation in yield and viability of menstrual endometrial tissue between volunteers and even between separate donations by the same volunteer on the same day. However, there was no relation between the amount of menstrual tissue and the observed mesothelial cell changes. One menstrual sample does not necessarily correlate with the total amount of menstruation, since menstrual shedding is a continuous process lasting several days. 
In conclusion, we have shown that menstrual effluent induces severe morphologic alterations in cultured mesothelial cells. Menstrual endometrial tissue fragments remain viable in peritoneal fluid for at least 72 hours and are candidates for adherence to peritoneum at sites where the submesothelial tissue has become exposed. The shed endometrial fragments themselves may have inflicted this exposure.

\section{References}

Andreoli, S. P., Mallett, C., Williams, K., McAteer, J. A., Rothlein, R. and Doerschuk, C. M. (1994) Mechanisms of polymorphonuclear leukocyte mediated peritoneal mesothelial cell injury. Kidney Int, 46, $1100-1109$.

Buck, R. C. (1973) Walker 256 tumour implantation in normal and injured peritoneum studied by electron microscopy, scanning electron microscopy, and autoradiography. Cancer Res, 33, 31813 is8.

Groothuis, P. G., Koks, C. A., de Goeij, A. F., Dunselman, G. A., Arends, J. W. and Evers, J. L. (1998) Adhesion of human endometrium to the epithelial lining and extracellular matrix of amnion in vitro: an electron microscopic study. Hum Reprod, 13, 2275-2281.

Koks, C. A., Dunselman, G. A., de Coeij, A. F., Arends, J. W. and Evers, J. L. (1997) Evaluation of a menstrual cup to collect shed endometrium for in vitro studies. Fertil Steril, 68, 560-564.

Koks, C. A., Groothuis, P. G., Dunselman, G. A., de Goeij, A. F. and Evers, J. L. (1999) Adhesion of shed menstrual tissue in an in vitro model using amnion and peritoneum: a light and electron microscopic study. Hum Reprod, 14, 816-822.

Koutsilieris, M., Allaire-Michaud, L., Fortier, M. and Lemay, A. (1991) Mitogen(s) for endometriallike cells can be detected in human peritoneal fluid. Fertil Steril, 56, 888-893.

Niedbala, M. J., Crickard, K. and Bernacki, R. J. (1985) Interactions of human ovarian tumour cells with human mesothelial ceils grown on extracellular matrix. An in vitro model system for studying tumour cell adhesion and invasion. Exp Cell Res, 160, 499-513.

Overton, C. E., Fernandez-Shaw, S., Hicks, 8., Barlow, D. H. and Starkey, P. (1997) In vitro culture of endometrial stromal and gland cells as a model for endometriosis: the effect of peritoneal fluid on proliferation. Fertil Steril, 67, 5 1-56.

Ramey, J. W. and Archer, D. F. (1993) Peritoneal fluid: its relevance to the development of endometriosis. Fertil Steril, 60, 1-14.

Sampson, J. (1940) The development of the implantation theory for the origin of peritoneal endometriosis. Am J Obstet Gynecol, 40, 549-557.

Sharpe, K. L., Zimmer, R. L., Khan, R. S. and Penney, L. L. (1992) Proliferative and morphogenic changes induced by the coculture of rat uterine and peritoneal cells: a cell culture model for endometriosis. Fertil Steril, 58, 1220-1229.

Surrey, E. S. and Halme, J. (1990) Effect of peritoneal fluid from endometriosis patients on endometrial stromal cell proliferation in vitro. Obstet Gynecol, 76, 792-797.

Tabibzadeh, S. (1996) The signals and molecular pathways involved in human menstruation, a unique process of tissue destruction and remodeling. Mol Hum Reprod, 2, 77-92.

van Hinsbergh, V. W., Kooistra, T., Scheffer, M. A., Hajo van Bockel, J. and van Muijen, C. N. (1990) Characterization and fibrinolytic properties of human omental tissue mesothelial cells. Comparison with endothelial celis. Blood, 75, 1490-1497.

Wild, R. A., Zhang, R. J. and Medders, D. (1994) Whole endometrial fragments form characteristics of in vivo endometriosis in a mesothelial cell coculture system: an in vitro model for the study 
of the histogenesis of endometriosis. I Soc Gynecol Investig, 1, 65-68.

Yashiro, M., Chung, Y. S., Inoue, T., Nishimura, S., Matsuoka, T., Fujihara, T. and Sowa, M. (1996) Hepatocyte growth factor (HGF) produced by peritoneal fibroblasts may affect mesothelial cell morphology and promote peritoneal dissemination. Int $J$ Cancer, 67, 289-293.

Zhang, R. J., Wild, R. A. and Ojago, J. M. (1993) Effect of tumour necrosis factor- $\alpha$ on adhesion of human endometrial stromal celis to peritoneal mesothelial cells: an in vitro system. Fertil Steril, 59, $1196-1201$. 
$[$ Chapter 4$]$

\title{
Morphological changes in mesothelial cells induced by shed menstrual endometrium in vitro are not primarily due to apoptosis or necrosis
}

\author{
A.Y. Demir Weusten' \\ P.G. Groothuis ${ }^{1.2}$ \\ G.A.J. Dunselman ${ }^{12}$ \\ A.F.P.M. de Goeij ${ }^{1,3}$ \\ J.W. Arends $s^{1,3}$ \\ J.L.H. Evers ${ }^{1.2}$
}

'Research institute Growth and Development (GROW), Departments of 2 Obstetrics \& Gynaecology and 'Pathology, Academisch ziekenhuis Maastricht and Maastricht University, P.O. Box 5800, 6202 AZ Maostricht, The Netherlands.

Hum Reprod, 2000; 15, 1462-1468 
Chapter 4'

54 


\section{Abstract}

In a previous study on the pathogenesis of endometriosis we observed that constituents of menstrual effluent induce morphological alterations in human mesothelial cells. In this study we investigated whether these alterations were associated with apoptosis or necrosis or were the result of cellular remodeling. After overnight incubation of confluent monolayers of human omental mesothelial cells (HOMEC) with conditioned media prepared from menstrual effluent shed anterogradely, severe alterations in morphology were observed. Typical polygonal mesothelial cell cultures at confluency acquired elongated spindle morphology, resulting in gaps between the cells. In contrast, mesothelial cells from the control groups receiving culture medium only, retained a normal morphology. Immunofluorescence staining revealed that cytokeratin, vimentin and actin filaments are still present, homogenously distributed over the cell cytoplasm following changes in morphology. To evaluate whether the morphological alterations are associated with apoptosis and/or necrosis, the cells were stained with the M30 CytoDeath antibody or annexin V with propidium iodide and analysed using flow cytometry. Both the M30 CytoDeath antibody and annexin $V$ recognize epitopes that are exposed during early apoptosis. The results showed that only a small percentage (1-7\%) of the affected HOMEC are undergoing apoptosis or necrosis. We conclude that the profoundly altered morphology of HOMEC is a result of cellular remodeling and that the role of apoptosis and necrosis is negligible. Soluble paracrine factors released by cells isolated from menstrual effluent shed anterogradely may induce a reorganization of the cytoskeleton. As a result, the underlying basement membrane will be exposed and the mesothelium may no longer prevent implantation of retrogradely endometrium shed into the peritoneum, thus facilitating the development of endometriosis. 


\section{Introduction}

Although endometriosis is one of the most frequently encountered gynaecologic disorders, its pathogenesis is poorly understood. Viable endometrial fragments in retrograde menstrual effluent (Kruitwagen et al., 1991) spilling into the abdominal cavity, are suspected to implant on the peritoneum (Sampson, 1940). Alternatively, endometrial cells may induce the mesothelial cells to differentiate into endometrium-like tissue (Levander and Normann, 1955).

In previous studies, we have shown that cells obtained from proliferative endometrium and menstrual endometrium do not adhere to the intact mesothelial monolayer of the peritoneum. Denudation of the mesothelium allows endometrial cells to attach to the underlying basement membrane (Groothuis et al., 1999; Koks et al., 1999). Recently, we observed that cells isolated from menstrual effluent as well as conditioned medium prepared from menstrual effluent are able to induce morphological alterations in cultured mesothelial cells (Koks et al., 2000). These changes in morphology resulted in exposure of the underlying basement membrane. Based on these observations we speculated that by altering the morphology of mesothelial cells, constituents of menstrual effluent may create their own adhesion sites. Morphological alterations, including cell shrinkage, condensation and change into a round morphology have also been associated with cells undergoing either apoptosis or necrosis (Majno and Joris, 1995).

In this study we investigated whether the morphological alterations in mesothelial cells induced by the refluxed endometrial cells are the result of the induction of apoptosis or necrosis or, alternatively, are the result of cellular remodeling. Changes in the cytoskeleton were evaluated using immunofluorescent staining of cytokeratin and actin filaments. Apoptosis was evaluated with the DNA fragmentation assay as well as flow cytometry using the M30 CytoDeath antibody (Leers et al., 1999) and annexin V binding (Martin et al. 1995; Darzynkiewicz et al., 1997). The M30 CytoDeath antibody binds to a caspasecleaved formalin-resistant epitope of cytokeratin 18, which is exposed during early apoptosis (Leers et al., 1999). Annexin V binds to phosphatidylserine (PS) that is translocated from the inner to the outer leaflet of the plasma membrane during early apoptosis (Darzynkiewicz et al., 1997). During necrosis the cell membrane is degraded, whereas during apoptosis the cell membrane remains intact (Darzynkiewicz et al., 1997). Therefore, to distinguish apoptotic from necrotic cells, cells were incubated with annexin $V$ combined with propidium iodide (PI), which only incorporates in nucleic acids after membrane damage (Darzynkiewicz et al., 1997). 


\section{Materials and Methods}

\section{Tissue collection and preparation of conditioned media}

Human omental tissue was obtained from female patients $(n=9)$ undergoing abdominal surgery for benign indications. All patients gave written informed consent. The institutional research review board and the medical ethics committee approved the study protocol.

A total of 54 samples of antegradely shed menstrual effluent were collected by 11 healthy volunteers using a menstrual cup (Koks et al., 1997). The volunteers had no history of endometriosis and were not using oral contraception. Menstrual effluent was collected for 2-3 hours during the first 3 days of menstruation. When a donor delivered menstrual effluent more than once to the laboratory during the same cycle, the conditioned media obtained were pooled and considered as one sample of conditioned medium. Thus, a total of 29 conditioned media was prepared from 54 menstrual effluents (Table 1).

After collection the menstrual effluent was immediately transferred to the laboratory in a sterile plastic tube. The effluent (5-10ml) was diluted with DMEM/Ham's F-12 (1:5) and mixed with a pasteur pipet until a homogenous suspension was achieved. To remove red blood cells, this suspension was layered on a HistoPaque 1077 gradient (Sigma-Aldrich

\section{Number of $\mathrm{CM}$ used in the experiments}

\begin{tabular}{ccccccc} 
Donor & MS & CM & LM & IHC/IF & M30 & Ann V \\
\hline $\mathbf{1}$ & 3 & 2 & 2 & - & 2 & 1 \\
$\mathbf{2}$ & 12 & 5 & 4 & 1 & 4 & 3 \\
$\mathbf{3}$ & 9 & 4 & 4 & 1 & 4 & 2 \\
$\mathbf{4}$ & 6 & 3 & 1 & 2 & 2 & 2 \\
$\mathbf{5}$ & 9 & 5 & 5 & 1 & 3 & 2 \\
$\mathbf{6}$ & 2 & 2 & - & 2 & - & - \\
$\mathbf{7}$ & 7 & 3 & 2 & 1 & - & 2 \\
$\mathbf{8}$ & 2 & 1 & - & 1 & - & - \\
$\mathbf{9}$ & 2 & 2 & 1 & 1 & 1 & - \\
$\mathbf{1 0}$ & 1 & 1 & - & 1 & - & - \\
$\mathbf{1 1}$ & 1 & 1 & 1 & - & 1 & - \\
\hline Total & $\mathbf{5 4}$ & $\mathbf{2 9 / 5 4}$ & $\mathbf{2 0 / 2 9}$ & $\mathbf{1 1 / 2 9}$ & $\mathbf{1 7 / 2 9}$ & $\mathbf{1 2 / 2 9}$
\end{tabular}

Table 1: Overview of the conditioned media (CM) used in the experiments: samples of menstrual effluent (MS), light microscopy (LM), immunohistochemistry and immunofluorescence (IHC/IF), flow cytometric analysis using M30 CytoDeath antibody (M30) and Annexin V binding (Ann V). 
Chemie B.V., Zwijndrecht, The Netherlands) and centrifuged at. $1167 \mathrm{~g}$ for 5 minutes. All cell suspensions were centrifuged in a Hettich centrifuge. The interphase containing endometrial and inflammatory cells was collected, washed two times in DMEM/Ham's F-12 and resuspended in control medium consisting of DMEM/Ham's F-12 supplemented with $10 \%$ fetal calf serum, $100 \mathrm{IU} / \mathrm{ml}$ penicillin, $100 \mu \mathrm{g} / \mathrm{ml}$ streptomycin and $2 \mathrm{mM}$ L-glutamine (all from Life Technologies). The suspension was plated in a T25 tissue culture flask (Costar; Corning Inc., Corning, NY, USA). After culturing for 24 hours at $37^{\circ} \mathrm{C}$ and $5 \% \mathrm{CO}_{2}$, the culture supernatant was collected, centrifuged at $1680 \mathrm{~g}$ for 10 minutes in a microfuge and stored at $-80^{\circ} \mathrm{C}$.

\section{Isolation of human omental mesothelial cells (HOMEC)}

The procedure as described by Kern et al. (Kern et al., 1983) has been used after minor modifications. The tissue was minced and incubated in $2 \mathrm{mg} / \mathrm{ml}$ collagenase (ICN Biomedicals B.V., Zoetermeer, The Netherlands) in DMEM/ Ham's F-12 at $37^{\circ} \mathrm{C}$ for $15-20$ minutes. After digestion, the suspension was filtered through a $400 \mu \mathrm{m}$ stainless steel sieve (Sigma-Aldrich). The filtrate was centrifuged ( $30 \mathrm{~g}$ for 10 minutes) after which the floating fat cells were removed. Following a second centrifugation step (605 $g$ for 5 minutes), the supernatant was discarded and the pellet resuspended in DMEM/Ham's F-12. This suspension was subsequently filtered through a $100 \mu \mathrm{m}$ nylon mesh filter (Micronic, Lelystad, The Netherlands) and a $10 \mu \mathrm{m}$ polyamid filter (Stokvis \& Smits, IJmuiden, The Netherlands). Mesothelial cells retained on the $10 \mu \mathrm{m}$ filter were back-washed with DMEM/Ham's F-12, pelleted once more and resuspended in MEM (D-valine, Life Technologies) supplemented with 20\% FCS, ITS (insulin, selenium and transferrin), $100 \mathrm{IU} / \mathrm{ml}$ penicillin and $100 \mu \mathrm{g} / \mathrm{ml}$ streptomycin. High serum concentration as well as the presence of D-valine instead of L-valine are known to selectively inhibit fibroblast growth in vitro (Gilbert and Migeon, 1975). In addition, the cells were subjected to differential plating. The cell suspension was transferred to a $T 25$ flask and incubated at $37^{\circ} \mathrm{C}$. Omental fibroblasts adhered within 30 minutes, whereas most mesothelial cells did not. After incubating for 30 minutes the supernatant with the non-adherent mesothelial cells was collected and transferred to a new T25 culture flask. After reaching confluency the mesothelial cells were detached by trypsin/EDTA treatment and were passaged with a split ratio of 1:3. Confluent or subconfluent HOMEC monolayers were used after the second or third passage.

To perform immunohistochemistry, HOMEC were plated on multi-chamber slides (ICN Biomedicals B.V.). To study the effect of conditioned media on mesothelial cell morphology, celis were plated in 24-well plates. For flow cytometric analysis HOMEC were plated in 6-well plates.

\section{Treatments}

Three treatment groups were included in all experiments: (i) Negative controls were human omental mesothelial cells (HOMEC) cultured for 3-4 days in control medium con- 
sisting of DMEM/Ham's FI2 supplemented with 10\% FCS, $100 \mathrm{IU} / \mathrm{ml}$ penicillin, $100 \mu \mathrm{g} / \mathrm{ml}$ streptomycin and $2 \mathrm{mM}$ L-glutamine (Gibco, Life Technologies). (ii) Positive controls; after an adaptation period of 2-3 days in control medium, HOMEC were cultured overnight in control medium supplemented with etoposide (200 $\mu \mathrm{M}$, Omnilabo International B.V., Breda, The Netherlands). Etoposide inhibits DNA topoisomerase II-alpha and induces apoptosis in various cell types (Bortner et al., 1995). (iii) For the experimental group, HOMEC were cultured overnight in conditioned medium.

\section{Characterization of HOMEC morphology}

Immunohistochemistry was applied to evaluate the purity of the mesothelial cell cultures. Mesothelial cells were stained with monoclonal antibodies against the epithelial cell marker cytokeratin (RCK 106, 1:10) (Ramaekers et al, 1990), the stromal cell marker vimentin (1:100, ICN Biomedicals B.V.) and the endothelial cell marker CD34 (1:200, Berkton Dickinson, San Jose, CA, USA). In brief, cells were rinsed in Tris-buffered saline (TBS, pH 7.4) and fixed in methanol for 1 minute at $-20^{\circ} \mathrm{C}$, followed by an aceton dip. The cells were rinsed three times in TBS and incubated with the primary antibodies for 1 hour at room temperature. After incubation, cells were rinsed three times in TBS and incubated for 1 hour at room temperature with biotinylated sheep anti-mouse IgG ( $1: 250$, Amersham Nederland B.V., Den Bosch, The Netherlands). Cells were washed again three times in TBS and incubated with a streptavidin-biotin-peroxidase complex $(1: 1000$, StreptABC kit, DAKO A/S, Glastrup, Denmark). Antibody binding was visualized using 3'-3'-diaminobenzidine and hydrogen peroxide. The slides were counterstained with hematoxylin.

After overnight incubation in the presence of control medium, etoposide or conditioned medium, morphological changes of HOMEC were characterized by conventional light microscopy and immunofluorescence. An indirect FITC-conjugated second antibody method using the antibody against vimentin, a pan-cytokeratin antibody against cytokeratins 5, 6, 8, 17, 19 (1:100, MNF1 16, DAKO A/S), and a direct rhodamine-conjugated phalloidin method for fibrillar actin (Friedman et al., 1984) were used to study changes in the cytoskeleton.

\section{DNA ladder assay}

After overnight incubation in the presence of $100 \mu \mathrm{M}$ etoposide, mesothelial cells were collected by scraping and pooled with the detached cells in the culture medium. After centrifugation, the pellet was resuspended in PBS containing proteinase $K(60 \mu \mathrm{g} / \mathrm{ml}$, Boehringer, Mannheim, Germany) and RNase A (100 $\mathrm{g} / \mathrm{ml}$, Boehringer) and incubated at $55^{\circ} \mathrm{C}$. After 1 hour, fresh proteinase $K(60 \mu \mathrm{g} / \mathrm{ml})$ was added and the suspension was incubated for another hour. Phenol/chloroform/isoamylalcohol (25:24:1) was added, and the mixture was vortexed. After centrifugation for 20 minutes, the top water phase was collected and $500 \mu \mathrm{l}$ of chloroform was added. Following vortexing and centrifugation, the DNA in the 
water phase was collected and precipitated with $3 \mathrm{M}$ sodiumacetate $(\mathrm{pH} 5.2)$ and 100\% absolute ethanol overnight at $-20^{\circ} \mathrm{C}$. The precipitated DNA was washed with $70 \%$ ethanol and centrifuged again. The pellet was then resuspended in TBS buffer and visualized with

Gel Star (FMC Bioproducts, Rockland, ME, USA) after 1.5\% agarose gel electrophoresis. The same procedure was applied to U-937 cells that grow in suspension and are known to show a DNA ladder pattern after treatment with etoposide (Bortner et al., 1995).

\section{Flow cytometry}

For flow cytometric analysis, a FACSort equipped with a single Argon ion laser (Beckton Dickinson, Sunnyvale, CA, USA) was used. Data analysis was performed with CELLQuest software (Beckton Dickinson). Data were gated on pulse-processed propidium iodide signals to exclude doublets and larger aggregates as a standard procedure. Ten thousand cells per sample were analysed.

\section{Annexin V}

Mesothelial cells were trypsinized and combined with the detached cells in the culture supernatant and incubated with FITC-labeled annexin V $(1 \mu \mathrm{g} / \mathrm{ml}$, Nexins Research B.V., Hoeven, The Netherlands). Propidium iodide ( $\mathrm{Pl}, 5 \mu \mathrm{g} / \mathrm{ml}$ ) was added to the binding buffer (10 mM HEPES-NaOH, pH 7.4, $150 \mathrm{mM} \mathrm{NaCl}, 5 \mathrm{mM} \mathrm{KCl}, 1 \mathrm{mM} \mathrm{MgCl} 2,1.8 \mathrm{mM} \mathrm{CaCl}$ ) together with annexin $\mathrm{V}$. After incubating for 10 minutes on ice, the cells were washed three times with binding buffer and the FITC signal was quantitated on the flow cytometer. Twelve conditioned media were tested in two independent experiments.

\section{M30 CytoDeath antibody}

After trypsinization, the attached and detached HOMEC fractions in the culture supernatant were combined and fixed in methanol at $-20^{\circ} \mathrm{C}$. After 30 minutes, the cells were washed twice with PBS containing $0.1 \%$ Tween 20. Nonspecific binding was blocked with PBS containing $1 \%$ BSA and $0.1 \%$ Tween 20 at room temperature. After 10 minutes, the blocking buffer was removed and the cells were incubated in $100 \mu \mathrm{l}$ of M30 CytoDeath antibody (1:100, Boehringer, Mannheim, Germany) at room temperature for 60 minutes. To visualize M30 Cytodeath antibody, a FITC conjugated second antibody was used and the FITC signal was evaluated. Seventeen conditioned media prepared from endometrium from menstrual biopsies were tested in three independent experiments.

\section{Statistical analysis}

Analysis of the data obtained by flow cytometry was performed using two-way analysis of variance, using conditioned medium (fixed effect) and experiment (random effect) as inde- 
pendent variables and the logarithm of the observed cell counts as dependent variable. The use of the logarithm was considered necessary due to the heterogeneous variances observed in the data. Variance components were estimated using the type I sums of squares. To test the homogeneity of variances in the groups, the test of Levene was used (Brown and Forsythe, 1974), after removal of the groups containing only single observations.

\section{Results}

\section{Characterization of HOMEC cultures}

Mesothelial cells isolated from human omentum had a cobble stone appearance typical for these cells (Figure $7 A$ ). When cultured on glass, the cells stained positive for pan-cytokeratin and vimentin, but were negative for CD34 (Figure 1B-1D).
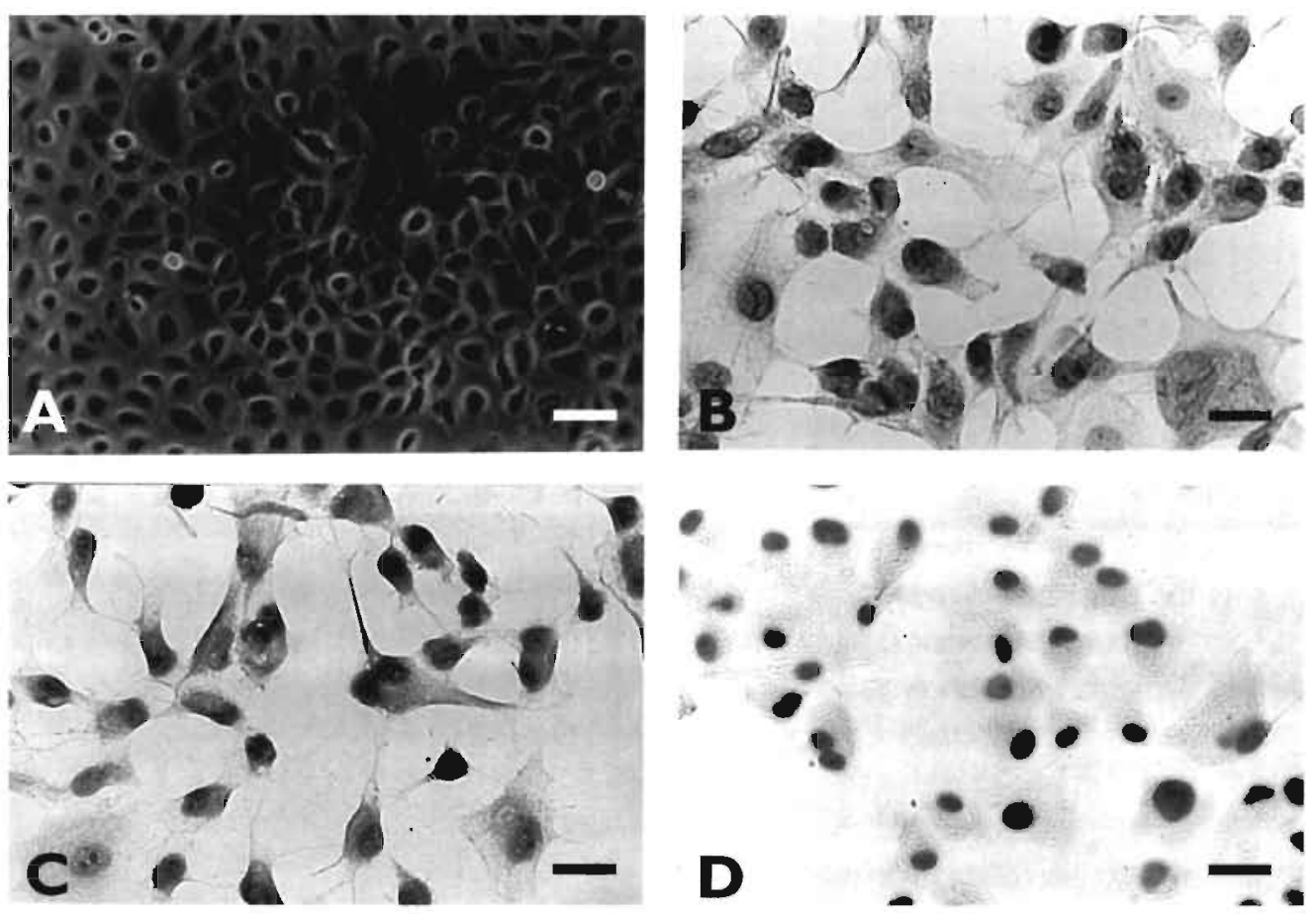

Figure 1: (A) The typical cobblestone appearance of a confluent monolayer of human mesothelial cells (HOMEC) grown on a plastic surface. Subconfluent monolayers of HOMEC grown on a glass surface stained positive brown with antibodies against pan-cytokeratin (B) and vimentin $(C)$ and negative for CD34 (D). Scale bars represent $100 \mu \mathrm{m}(A)$ and $40 \mu \mathrm{m}(B-D)$. 


\section{Effects of conditioned media on HOMEC morphology}

After 4-6 hours of incubation with conditioned medium, the HOMEC started to acquire a spindle-like morphology. Following overnight culture the effect became more severe, ultimately resulting in exposure of the culture surface (Figure 2). Morphological changes were induced by all of the conditioned media that were used for experiments. The degree of severity observed varied between conditioned media from different donors and from different cycles of the same donor (Figure 2).
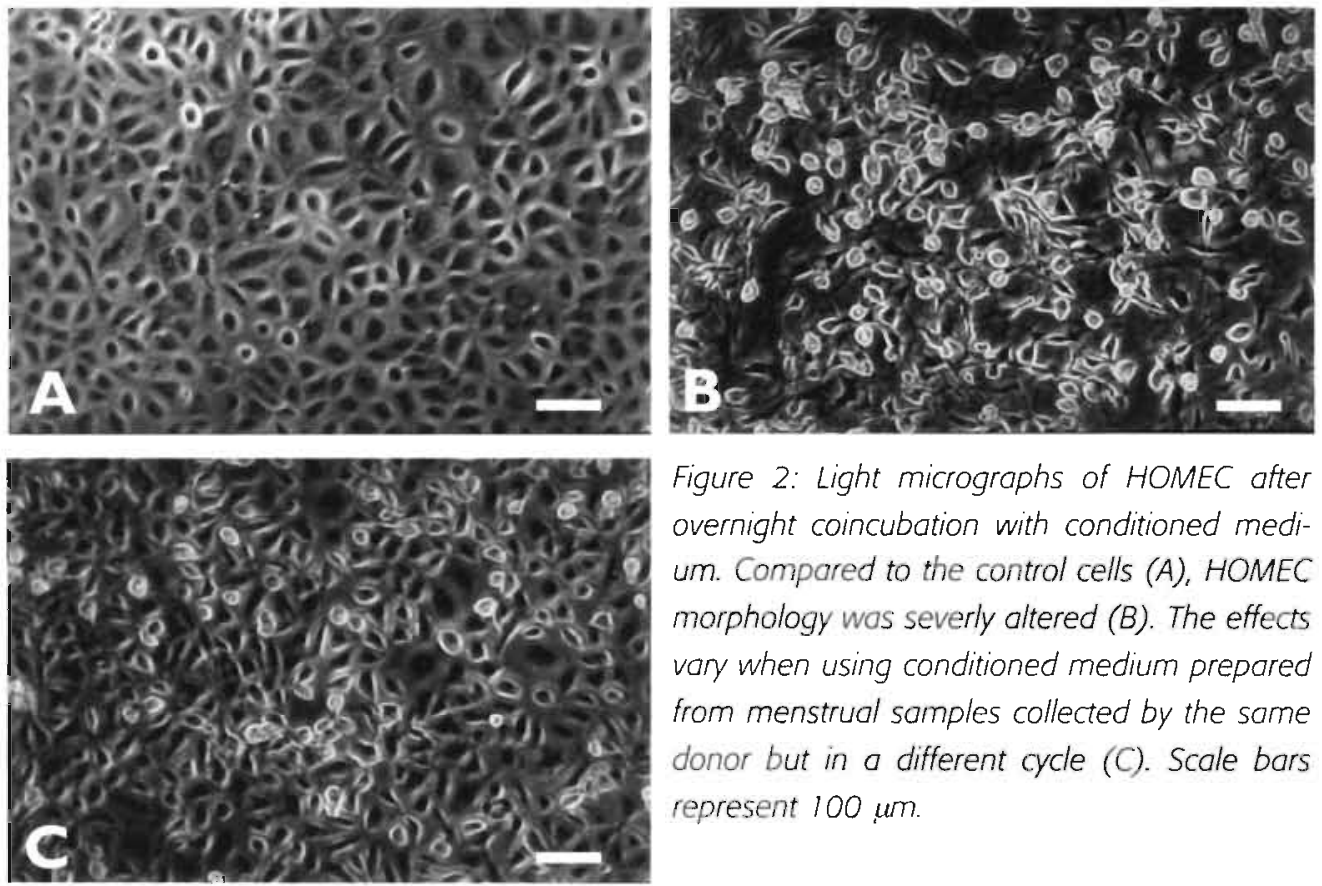

Figure 2: Light micrographs of HOMEC after overnight coincubation with conditioned medium. Compared to the control cells (A), HOMEC morphology was severly altered $(B)$. The effects vary when using conditioned medium prepared from menstrual samples collected by the same donor but in a different cycle (C). Scale bars represent $100 \mathrm{um}$.

After the alterations in mesothelial cell morphology, the cytokeratin and actin filaments were still present, but their staining pattern appeared to be affected (Figure 3). In control cultures cytokeratin filaments were concentrated around the nucleus (Figure 3A), whereas actin filaments are more concentrated in foci at the periphery of cells (Figure 3B). Upon incubation with conditioned media, both cytokeratin and actin filaments appear to be distributed equally in the cytoplasm (Figures 3C, 3D), with concentration of cytokeratin filaments in the fibroblast-like extentions (Figure 3C). The distribution of vimentin was similar to that observed for cytokeratin (results not shown).

\section{DNA ladder assay}

U-937 cells displayed a DNA ladder upon incubation with etoposide, whereas HOMEC did not show this ladder (Figure 4). 

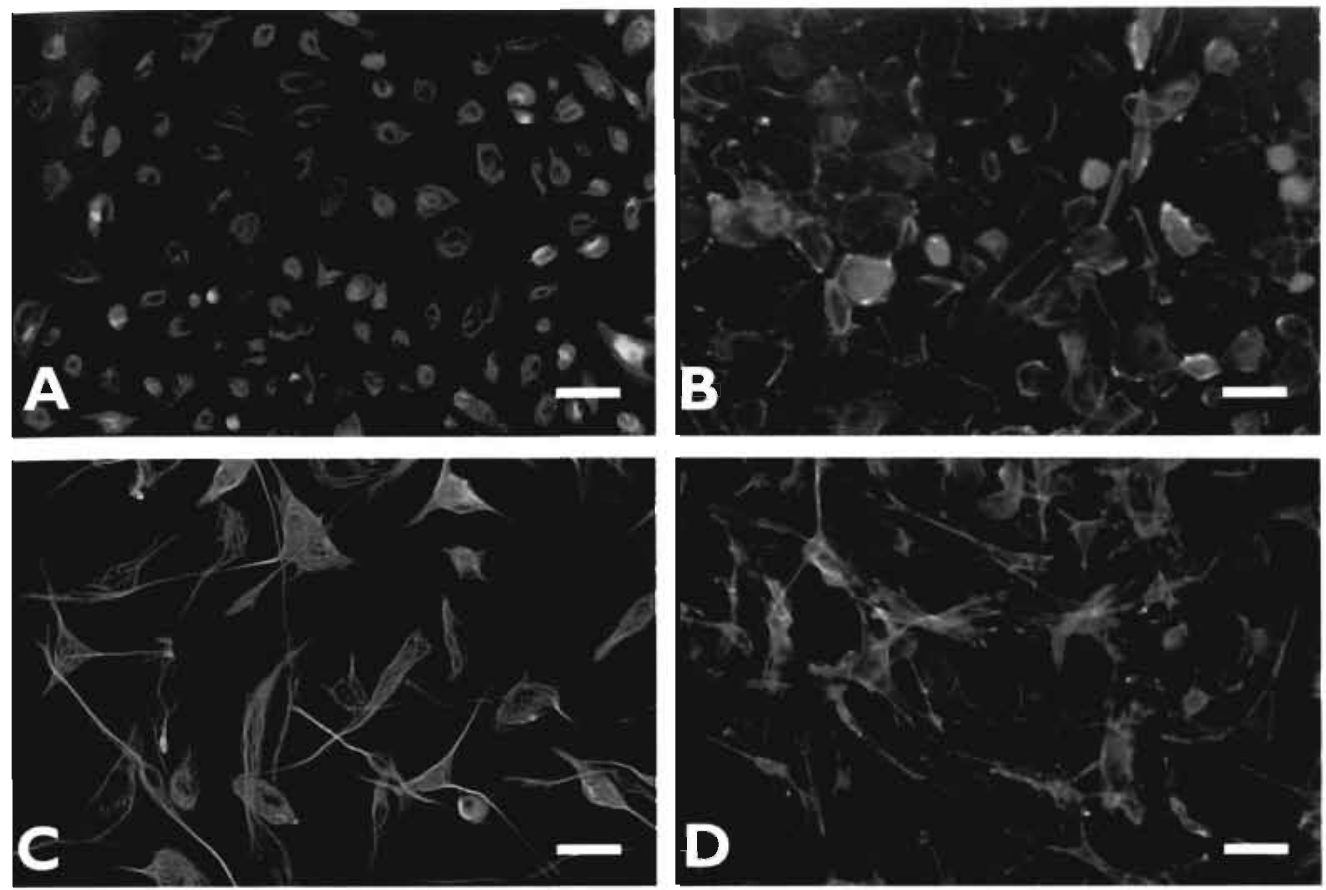

Figure 3: Fluorescence micrographs of HOMEC stained with pan-cytokeratin $(A, C)$ and rhodamineconjugated phalloidin $(B, D)$, showing the staining patterns before $(A, B)$ and after $(C, D)$ incubation with conditioned medium. Scale bar represents $40 \mu \mathrm{m}$.

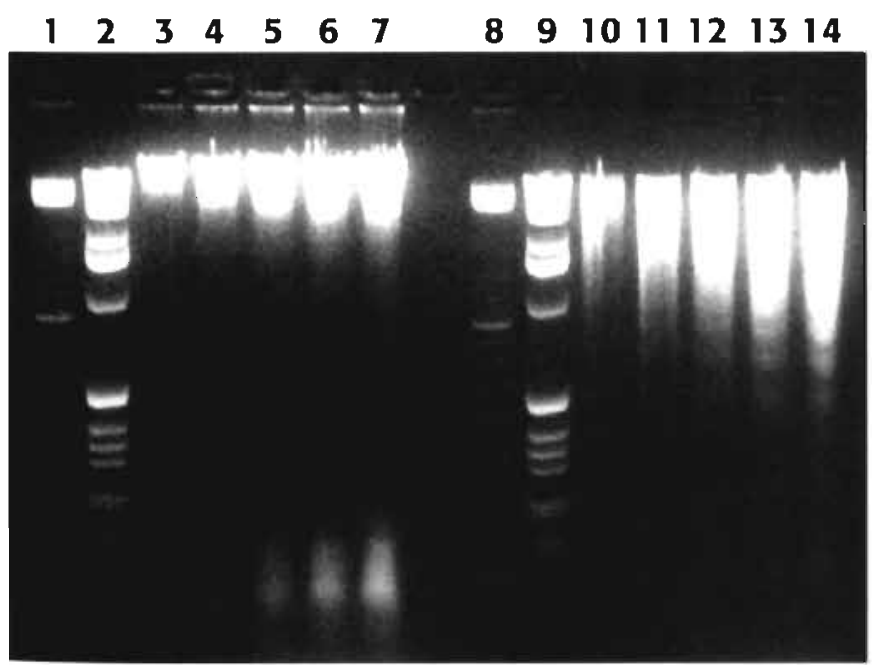

Figure 4: Results of the DNA ladder assay: lanes 1 and 8 are 100 bp ladders; lanes 2 and 9 are $1 \mathrm{~kb}$ ladders; lones 3-7 and lones 10-14 are increasing amounts of genomic DNA isolated from mesothelial cells and U-937 respectively after overnight incubatior with $100 \mu \mathrm{M}$ etoposide. 


\section{Flow cytometry}

Figure 5 illustrates the effects of both the etoposide and conditioned media on mesothelial cell morphology, just prior to flow cytometric analysis. In both cases severe morphological alterations occurred. However, etoposide-induced cells appeared to be more rounded up, whereas cells incubated with conditioned media had a more spindle-like appearance. Figure 6 shows some respresentative results of flow cytometric analysis. Figure 7 summarizes the data of all independent experiments.
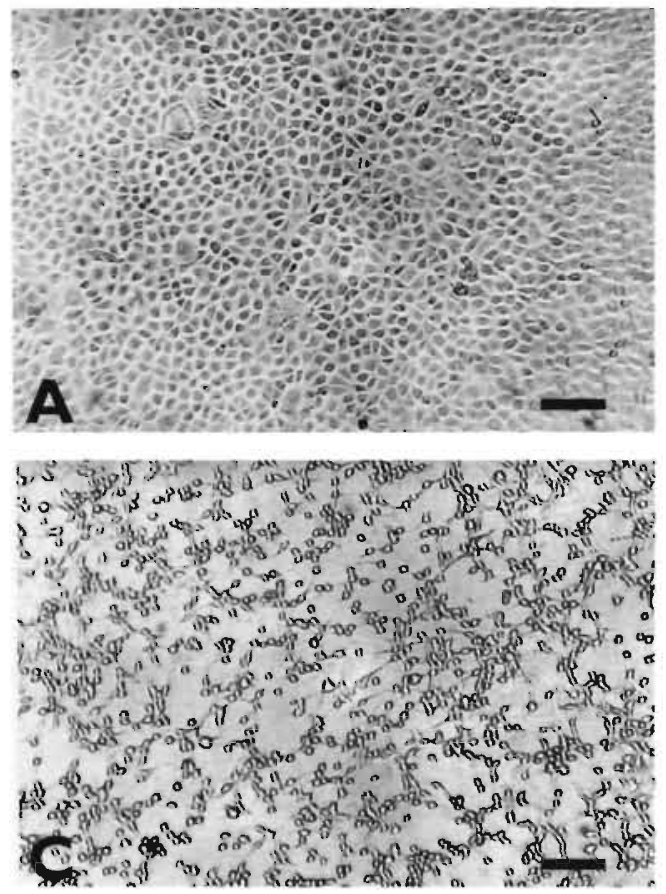

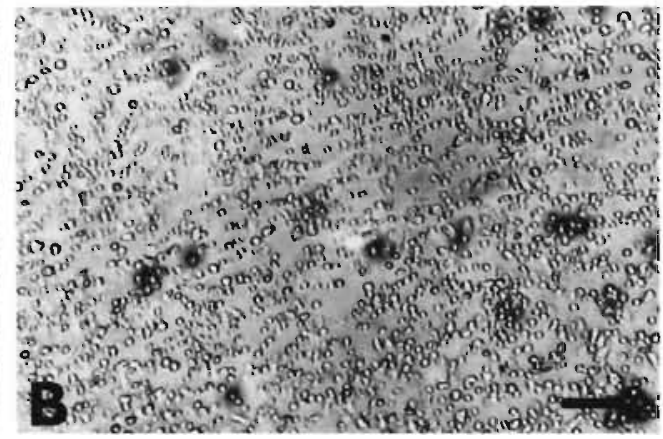

Figure 5: Light micrograph showing cultures of HOMEC before $(A)$ and after overnight incubation with $200 \mathrm{mM}$ etoposide $(B)$ or conditioned medium (C). Scale bar represents $250 \mu \mathrm{m}$.

Figures $6 A, 6 B$ and 7 show the negative controls for M30 CytoDeath antibody (1.3\% \pm 0.04 ) and annexin $V$ binding $(1.2 \% \pm 0.5)$. After incubation with etoposide the number of M30 positive cells (Figure 6C) and annexin V positive cells (Figure 6D) increased dramatically. In addition, a large fraction of the annexin $V$ positive fraction stained positive for $\mathrm{PI}$ due to secondary necrosis (Figure $6 D$ ). When cultured in conditioned media, 1.9\% $( \pm 0.9)$ of the cells stained positive with the M30 CytoDeath antibody (Figures $6 E, 6 G, 7$ ), and $2.8 \%( \pm 2.2$ ) of the cells stained positive for annexin $V$ (Figures $6 F, 6 H, 7$ ).

Figure 6: Flow cytometric measurements of HOMEC labelled with M30 CytoDeath antibody ( $A, C$, $E, G)$ and annexin $V(B, D, F, H) .(A, B)$ control cultures, $(C, D) 200 \mu M$ etoposide, $(E-H)$ conditioned media. 
M30 CytoDeath

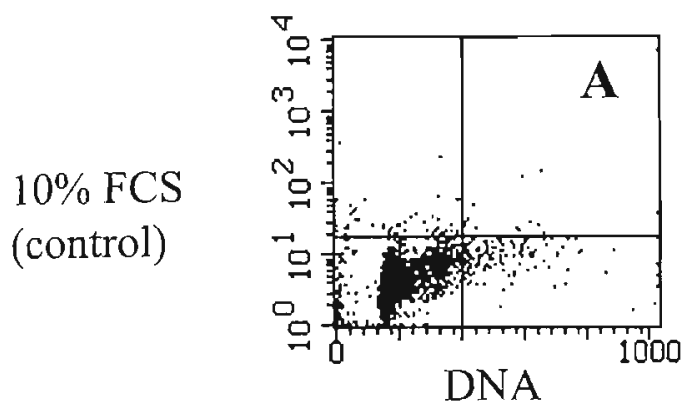

Etoposide

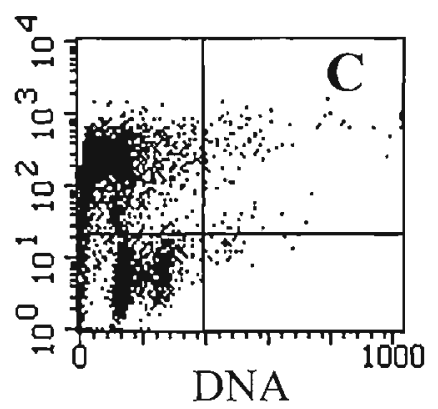

Conditioned

$\nabla$

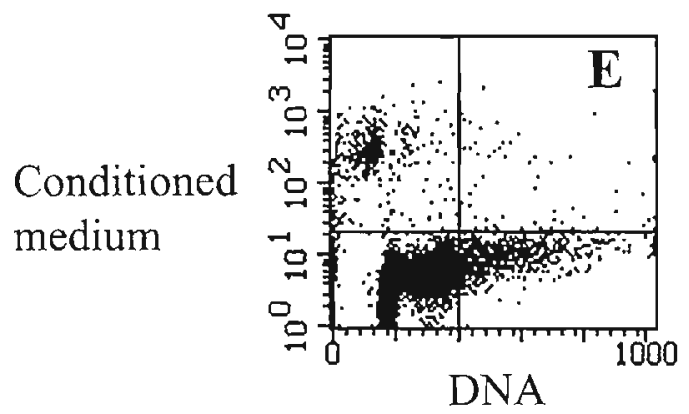

Conditioned medium

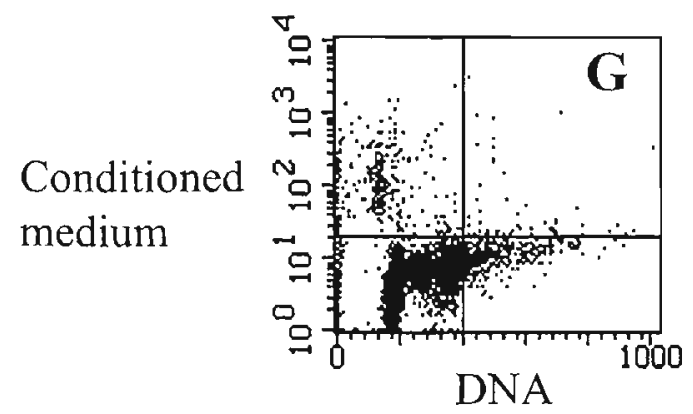

\section{Annexin V}
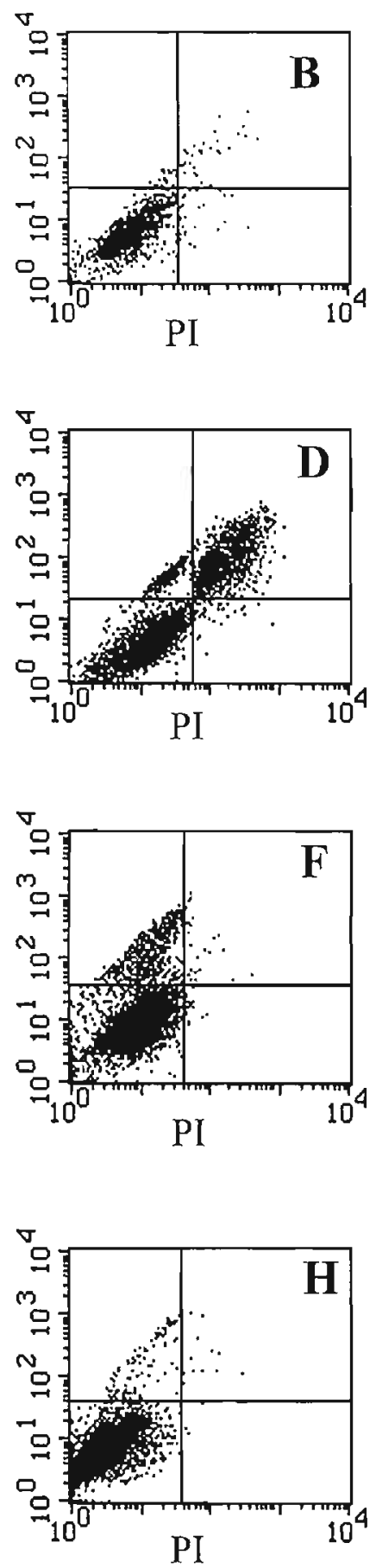


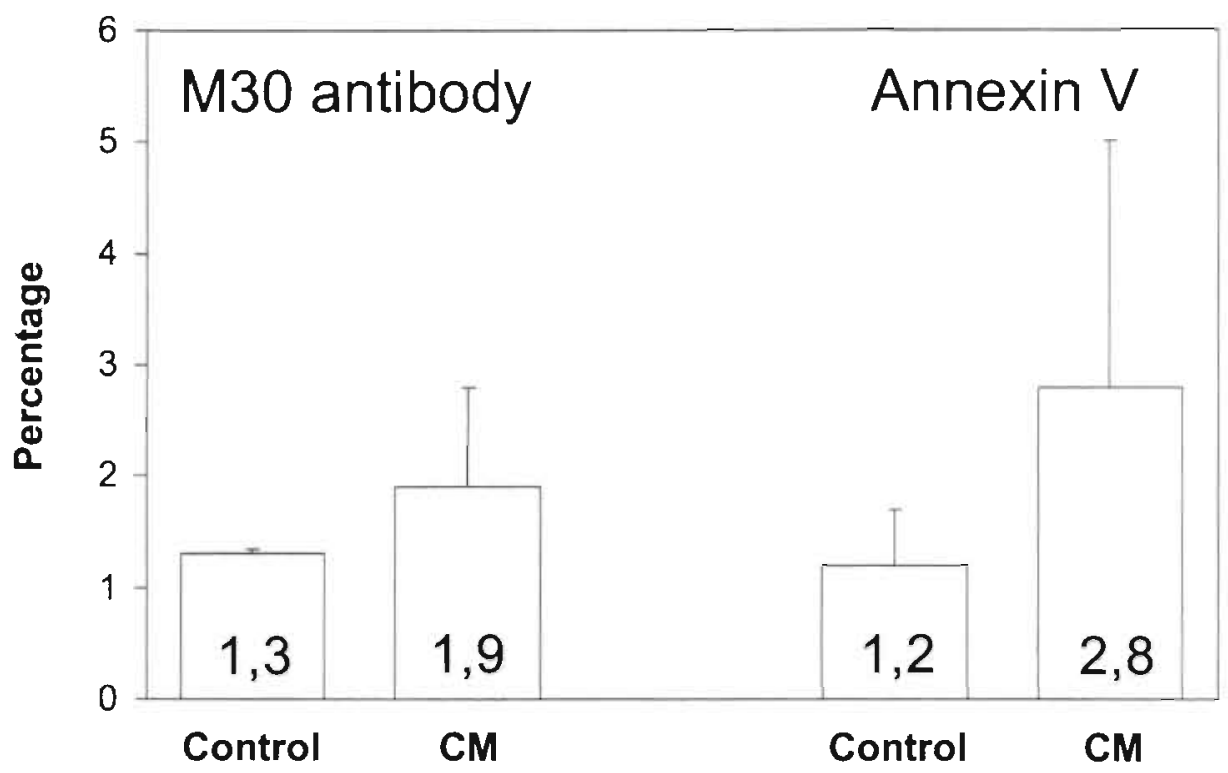

Figure 7: Summary of the results of the flow cytometry experiments. The M30 data represent three independent experiments in which 17 conditioned media were tested. The annexin $V$ data represent the dato of two independent experiments in which 12 conditioned media were tested. Bars represent the overall mean $\pm S D$.

For the $\mathrm{M} 30$ positive and annexin $\mathrm{V}^{+} / \mathrm{Pl}^{+}$(necrotic) cell fraction measurements, Levene's test of equality of error variances yielded no significance ( $p=0.84$ and 0.82 , respectively). Subsequent analysis revealed that culturing with conditioned media resulted in a small but significant increase in $\mathrm{M} 30$ positive cells $\left(\mathrm{p}=0.039\right.$ ). For the annexin $\mathrm{V}^{+} / \mathrm{PI}^{+}$(necrotic) cell fractions no significant effect of the medium was observed $(p=0.08)$. For the annexin $\mathrm{V}^{+} / \mathrm{Pl}^{-}$(apoptotic) cell fractions, Levene's test of equality of error variances did yield highly significant results $(p=0.003)$, thus complicating further analyses. However, since the observed $p$-value for the effect of the medium was clearly non-significant $(p=0.61)$, it is still acceptable to assume that there was no effect of the medium on the annexin $\mathrm{V}^{+} / \mathrm{P}^{-}$ (apoptotic) cell fractions. When the analysis was performed on the original data, without the log transformation, similar results were obtained.

\section{Discussion}

Previously we have observed that components of the menstrual effluent induce severe morphological alterations in mesothelial cells. Similar alterations were observed in other epithelial-like cells, e.g. in HUVEC, primary endothelial cells and in ECC-1 cells, an endo- 
metrial carcinoma cell line (Koks et al., 2000). In the present study, we show that these changes are not the result of mesothelial cells undergoing apoptosis or necrosis.

Flow cytometric analysis revealed that only between 1 and $7 \%$ of the HOMEC are apoptotic or necrotic after overnight incubation with conditioned media, whereas the morphology of almost all mesothelial cells was affected. The results of the DNA fragmentation assay showed that mesothelial cells are not subject to internucleosomal DNA cleavage, leading to the typical DNA ladder, and could therefore not be used to evaluate apoptosis. Thus, apoptosis in mesothelial cells is more likely to be associated with cleavage into large fragments or single-strand DNA cleavage (Bortner et al., 1995).

Light microscopy observations showed that the staining pattern of cytokeratin, vimentin and actin filaments in mesothelial cells appeared to be affected after incubation with conditioned media. Apparently, cellular remodeling rather than the initiation of apoptosis or necrosis is responsible for the observed alterations in cell morphology.

From oncology studies it is known that addition of tumour ascites fluid (Kimura et al., 1985; Akedo et al., 1986) and conditioned medium to cultured mesothelial cells (Niedbala et al., 1985), as well as the intraperitoneal injection of tumour ascites fluid or cells (Kiyasu et al., 1981; Kishikawa et al., 1995), also change the morphology of mesothelial cells. These changes, including disruption of intercellular junctions, retraction and exfoliation of mesothelial cells, lead to the exposure of the underlying extracellular matrix and subsequent attachment and proliferation of tumour cells. Based on these and other observations it has been suggested that infiltration of cancer cells into the peritoneum is also prevented by mesothelial cell monolayers (Leighton et al., 1959). Furthermore, others (Yashiro et al. 1996) incubated peritoneal cell monolayers with serum-free conditioned medium prepared from eutopic peritoneal fibroblasts, and observed that mesothelial cells also rounded up or exhibited a fibroblast-like morphology. From their results, Yashiro et al. (Yashiro et al., 1996) suggested that soluble factors, such as hepatocyte growth factor, affect the morphology of mesothelial cells in monolayer culture, so that the resulting environment may become prone to the peritoneal dissemination of cancer cells. It is clear that the mesothelial lining is very susceptible to alterations inflicted by local or ectopic cells, presumably through the production of paracrine factors.

The interaction between cells isolated from endometrium and mesothelial cell monolayer cultures has also been studied before (Sharpe et al., 1992; Wild et al., 1994; Witz et al., 1999). None of these studies reported distinct morphological changes. It has to be taken into account, however, that the endometrium was collected in the proliferative and secretory phase of the menstrual cycle, rather than the menstrual phase. The findings from these studies are in accordance with previous observations that conditioned medium prepared from cyclic endometrium does not affect mesothelial cell morphology (Koks et al., 2000).

We have shown that paracrine factors released by menstrual tissue induce changes in cell shape and exposure of extracellular matrix (Koks et al., 2000). Several mechanisms may potentially be responsible for this. For instance, the paracrine factors may bind to cell 
surface receptors and initiate a signaling cascade which eventually results in cellular remodeling. Growth factor receptors are often tyrosine kinases, and after activation by their ligand they are able to induce changes in cellular morphology by altering the phosphorylation status of focal adhesion associated proteins (Burridge et al., 1997; Nelson and Fry, 1997). These focal adhesion complexes are the major sites of actin filament and changes in the distribution of focal adhesion points would therefore result in a redistribution of the actin cytoskeleton (Gumbiner, 1996). These issues are currently under investigation in our laboratory.

We conclude that cells isolated from spontaneously shed menstrual effluent, as opposed to cells obtained from endometrial biopsies, are potentially harmful to the mesothelium. Menstrual effluent shed retrogradely may behave aggressively and damage the mesothelial lining upon entering the abdominal cavity, thus creating adhesion sites. The anatomical distribution of peritoneal endometriosis supports this contention, since most endometriotic lesions are found in the proximity of the Fallopian tube ostia, i.e. on the ovaries and uterine ligaments. It will be of clinical importance to identify the factors responsible for the disruptive effect on the mesothelium. Prevention or neutralization of this effect would aid in reducing the chance of endometriosis development.

\section{Acknowledgements}

The authors wish to thank Dr. J.J.A.M. Weusten (Organon Technika) for the statistical analysis of the flow cytometry data, Prof. Dr. F.C.S. Ramaekers (Department of Molecular and Cellular Biology, University Maastricht) for donating the RCK 106 antibody and the rhodamine-conjugated phalloidin, Dr. Roel Kuijer (Department of Biomaterials, University Maastricht) for supplying etoposide.

\section{References}

Akedo, H., Shinkai, K., Mukai, M., Mori, Y., Tateishi, R., Tanaka, K., Yamamoto, R. and Morishita, T. (1986) Interaction of rat ascites hepatoma cells with cultured mesothelial cell layers: a model for tumour invasion. Cancer Res, 46, 2416-2422

Bortner, C. D. Oldenburg, N. B. E. and Cidlowsky, J. A. (1995) The role of DNA fragmentation in apoptosis. Trends in cell biology, 5, 21-26.

Brown, M. B. and Forsythe, A. B. (1974) Robust tests for the equality of variances. I Am Statist Așsoc, 69, 364-367.

Burridge, K., Chrzanowska-Wodnicka and Zhong, C. (1997) Focal adhesion assembly. Trends in Cell Biology: 7, 342-347.

Darzynkiewicz, Z., Juan, G., Li, X., Gorczyca, W., Murakami, T. and Traganos, F. (1997) Cytometry in cell necrobiology: analysis of apoptosis and accidental cell death (necrosis). Cytometry, 27, 1-20.

Friedman, E., Verderame, M., Winawer, S. and Follack, R. (1984) Actin cytoskeletal organization loss in the benign-to-malignant tumour transition in cultured human colonic epithelial cells. Concer Res, 44, 3040-3050. 
Gibert, S. F. and Migeon, B. R. (1975) D-valine as a selective agent for normal human and rodent epithelial cells in culture. Cell, 5, 11-17.

Groothuis, P. G., Koks, C. A., de Goeij, A. F., Dunselman, G. A., Arends, J. W. and Evers, J. L. (1999) Adhesion of human endometrial fragments to peritoneum in vitro. Fertil Steril, 71, 1119-1124.

Gumbiner, B. M. (1996) Cell adhesion: the molecular basis of tissue architecture and morphogenesis. Cell, 84, 345-357.

Kern, P. A., Knedler, A. and Eckel, R. H. (1983) Isolation and culture of microvascular endothelium from human adipose tissue. J Clin Invest, 71, 1822-1829.

Kimura, A., Koga, S., Kudoh, H. and litsuka, Y. (1985) Peritoneal mesothelial cell injury factors in rat cancerous ascites. Concer Res, 45, 4330-4333.

Kishikawa, T., Sakamoto, M., Ino, Y., Kubushiro, K., Nozawa, S. and Hirohashi, S. (1995) Two distinct patterns of peritoneal involvement shown by in vitro and in vivo ovarian cancer dissemination models. Invasion Metastasis, 15, 11-21

Kiyasu, Y., Kaneshima, S. and Koga, S. (1981) Morphogenesis of peritoneal metastasis in human gastric cancer. Cancer Res, 41, 1236-1239.

Koks, C. A., Dunselman, G. A., de Goeij, A. F., Arends, J. W. and Evers, J. L. (1997) Evaluation of a menstrual cup to collect shed endometrium for in vitro studies. Fertil Steril, 68, 560-564.

Koks, C. A., Groothuis, P. G., Dunselman, G. A., de Coeij, A. F. and Evers, J. L. (1999) Adhesion of shed menstrual tissue in an in vitro model using amnion and peritoneum: a light and electron microscopic study. Hum Reprod, 14, 816-822.

Koks, C. A., Dernir Weusten, A. Y., Groothuis, P. G., Dunselman, G. A., de Coeil, A. F. and Evers, J. L. (2000) Menstruum induces changes in mesothelial cell morphology. Gynecol Obstet Invest, 50, $13-18$

Kruitwagen, R. F., Poels, L. G., Willemsen, W. N., de Ronde, I. J., Jap, P. H. and Rolland, R. (1991) Endometrial epithelial cells in peritoneal fluid during the early follicular phase. Fertil Steril, 55, $297-303$.

Leers, M. P., Kolgen, W., Bjorklund, V., Bergman, T., Tribbick, G., Persson, B., Bjorklund, P., Ramaekers, F. C., Bjorklund, B., Nap, M. et al. (1999) Immunocytochemical detection and mapping of a cytokeratin 18 neo-epitope exposed during early apoptosis. J Pothol, 187, 567-572.

Leighton, J., Kalla, R. L., Kline, I. and Belkin, M. (1959) Pathogenesis of tumour invasion. 1. Interaction between normal tissues and 'transformed' cells in culture. Cancer Res, 19, 23-27.

Levander, $G$. and Normann, P. (1955) The pathogenesis of endometriosis. An experimental study. Acto Obstet Gynecol Scond, 34, 366-398.

Majno, G. and Joris, I. (1995) Apoptosis, oncosis, and necrosis. An overview of cell death. Am J Pothol, 146, 3-15.

Martin, S. J., Reutelingsperger, C. P., McGahon, A. J., Rader, J. A., van Schie, R. C., L.aFace, D. M. and Green, D. R. (1995) Early redistribution of plasma membrane phosphatidylserine is a general feature of apoptosis regardless of the initiating stimulus: inhibition by overexpression of $\mathrm{Bcl}-2$ and $\mathrm{Abl}$. J Exp Med, 182, 1545-1556.

Nelson, J. M. and Fry, D. W. (1997) Cytoskeletal and morphological changes associated with the specific suppression of the epidermal growth factor receptor tyrosine kinase activity in A431 human epidermoid carcinoma. Exp Cell Res, 15, 383-390.

Niedbala, M. J., Crickard, K. and Bernacki, R. J. (1985) Interactions of human ovarian tumour cells with human mesothelial cells grown on extracellular matrix. An in vitro model system for studying tumour cell adhesion and invasion. Exp Cell Res, 160, 499-513.

Ramaekers, F., van Niekerk, C., Poels, L., Schaafsma, E., Huijsmans, A., Robben, H., Schaart, G. and Vooijs, P. (1990) Use of monoclonal antibodies to keratin 7 in the differential diagnosis of adenocarcinomas. Am J Pathol, 136, 641-655.

Sampson, J. (1940) The development of the implantation theory for the origin of peritoneal endometriosis. Am J Obstet Gynecol, 40, 549-557. 
Sharpe, K. L., Zimmer, R. L., Khan, R. S. and Penney, L. L. (1992) Proliferative and morphogenic changes induced by the coculture of rat uterine and peritoneal cells: a cell culture model for endometriosis. Fertil Steril, 58, 1220-1229.

Wild, R. A., Zhang, R. 1. and Medders, D. (1994) Whole endometrial fragments form characteristics of in vivo endometriosis in a mesothelial cell coculture system: an in vitro model for the study of the histogenesis of endometriosis. J Soc Gynecol Investig, 1, 65-68.

Witz, C. A., Monotoya-Rodriguez, I. A. and Schenken, R. S. (1999) Whole explants of peritoneum and endometrium: a novel model of the early endometriosis lesion. Fertil Steril, 71, 56-60.

Yashiro, M., Chung, Y. S., Inoue, T., Nishimura, S., Matsuoka, T., Fujihara, T. and Sowa, M. (1996) Hepatocyte growth factor (HGF) produced by peritoneal fibroblasts may affect mesothelial cell morphology and promote peritoneal dissemination. Int J Cancer, 67, 289-293. 


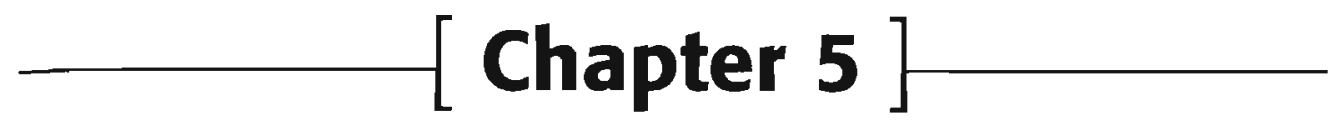

\title{
Menstrual effluent induces epithelial to mesenchymal transitions in mesothelial cells
}

\author{
A. Y. Demir ${ }^{13}$ \\ P.G. Groothuis ${ }^{1,3,4}$ \\ A.W. Nap ${ }^{1,3}$ \\ C. Punyadeera ${ }^{2,3}$ \\ A.F.P.M. de Goeii ${ }^{2.3}$ \\ J.L.H. Evers ${ }^{1.3}$ \\ G.A.J. Dunselman ${ }^{1.3}$
}

Departments of 'Obstetrics \& Gynaecology and 'Pathology, 'Research Institute Growth and Development (GROW), Academisch ziekenhuis Moostricht and Maastricht University, P.O. Box 5800, 6202 AZ Maastricht, The Netherlands.

Hum Reprod, 2004; 19, 21-29 
Chapter 5 


\section{Abstract}

Menstrual effluent affects mesothelial cell (MC) morphology. We evaluated whether these changes were consistent with epithelial to mesenchymal transitions (EMT).

Monolayer cultures of MC were incubated overnight in conditioned media, prepared from cells isolated from menstrual effluent, with or without kinase and ATP inhibitors. Changes in cell morphology were monitored using time-lapse video microscopy and immunohistochemistry. Effects on the expression of EMT-associated molecules were evaluated using real-time RT-PCR and/or Western-blot analysis.

Incubation in conditioned media disrupted cell-cell contacts, and increased MC motility. The changes were reversible. During the changes the distribution of cytokeratins, fibrillar actin and $\alpha$-tubulin changed. Sodium azide, an inhibitor of ATP production, and Genistein, a general tyrosine kinase inhibitor, antagonized these effects. Wortmannin, a phosphatidylinositol 3-kinase inhibitor, and SU6656, a Src tyrosine kinase inhibitor, only partially antagonized the effect. The expression of Snail and vimentin was markedly up-regulated, whereas the expression of E-cadherin was decreased and cytokeratins were altered.

In MC, menstrual effluent initiates a reversible, energy-dependent transition process from an epithelial to a mesenchymal phenotype. Involvement of the ( $\mathrm{Src}$ ) tyrosine kinase signaling pathway and the changes in the expression of cytokeratins, Snail, vimentin and E-cadherin demonstrate that the morphological changes are EMTT. 


\section{Introduction}

Endometriosis is characterized by lesions outside the uterine cavity, which consist of functional endometrial glands and stroma. This benign disease occurs during the reproductive years, and affected women suffer from abdominal pain, dysmenorrhoea, dyspareunia and infertility. Although the ideas about the pathogenesis of endometriosis remain controversial, most reports support Sampson's theory that endometriosis results from the adherence of retrogradely shed endometrium to the peritoneal lining, followed by invasion and growth.

The peritoneal lining consists of mesothelial cells which form a monolayer of epitheliumlike cells covering the surface of the abdominal cavity. These cells are strongly connected by well developed cell-cell junctional complexes, including tight junctions, adherens junctions, gap junctions and desmosomes (Mutsaers, 2002). An undamaged mesothelial architecture provides an important protective barrier against invading microorganisms and dissemination of ectopic cells (Mutsaers, 2002).

A traumatized or injured peritoneal surface has been shown to result in enhanced peritoneal tumour dissemination and tumour growth (Bouvy et al., 1996; Mathew et al., 1997; Reymond et al., 1998; Gutt et al., 2001). Such damage may be caused by tissue handling and drying out during laparotomy, increased intra-abdominal pressure during $\mathrm{CO}_{2}$ laparoscopy, or port site entry of trochars (Bouvy et al., 1996; Mathew et al., 1997; Reymond et al., 1998; Gutt et al., 2001). It has also been found that continuous ambulatory peritoneal dialysis is associated with recurrent episodes of peritonitis, which results in mesothelial detachment and in persistent peritoneal denudation (Andreoli et al., 1994; Yanez-Mo et al., 2003). This leads to increased intra-abdominal dissemination of cancer cells in these patients compared with non-dialysis patients (Bargman, 2000).

The early pathogenesis of endometriosis remains to be elucidated with regard to the initial interactions between menstrual endometrium and mesothelial cells. In our previous studies (Demir Weusten et al., 2000; Koks et al., 2000) shed menstrual effluent has been shown to induce morphological changes in mesothelial cells, which include disruption of intercellular junctions, retraction and exfoliation, and subsequent exposure of underlying extracellular matrix. These morphological changes appeared not to be due to cell death and were likely the result of cellular remodeling (Demir Weusten et al., 2000). We hypothesize that retrogradely shed menstrual effluent interrupts the mesothelial lining by inducing cellular remodeling. This leads to the exposure of submesothelial extracellular matrix and may facilitate the adherence of endometrium fragments on peritoneum.

Similar phenotypical changes have been described by other investigators and were referred to as epithelial to mesenchymal transitions (EMT) (Boyer et al., 2000). This cellular process is a manifestation of epithelial plasticity during embryo and organ morphogenesis, wound healing and tumour progression. During EMT epithelial cells shift from an epithelial to a mesenchymal phenotype by reorganizing their cytoskeleton. The cellular features of epithelia prior to transformation are loss of polygonal morphology, adhesive cell 
contacts and cell polarity, development of a fibroblast-like shape with basal cytoplasmic projections, and increased cell motility (Hay, 1995). At the molecular level the zinc finger transcription factor Snail has been recently implicated in the switching mechanism for EMT (Nieto, 2002). Snail binds to E-boxes in the E-cadherin promoter and directly represses E-cadherin expression (Cano et al., 2000), resulting in the dissociation of intercellular junctions and an increase in the pool of cytoplasmic $\beta$-catenin, a key component of the Wht signaling pathway. Many transforming epithelia also change their intermediate filaments from cytokeratin to vimentin, a cytoskeletal shift that seems to be mandatory for the start of the transformation process (Perez-Pomares and Munoz-Chapuli, 2002).

In several cell culture models, EMT are induced by a number of tyrosine kinase receptor binding growth factors, such as epithelial growth factor (ECF), insulin like growth factor (IGF), fibroblast growth factor (FGF), hepatocyte growth factor/scatter factor (HGF/SF) or transforming growth factor- $\beta$ (TCF- $\beta$ ) (Gavilovic et al., 1990; Valles et al., 1990; Piek et al., 1999; Morali et al., 2001; Strutz et al., 2002). In these cases several kinase signaling pathways have been implicated, which involve oncogenic Src, Ras, Raf, phosphatidylinositol-3 kinase ( $\left.\mathrm{Pl}_{3} \mathrm{~K}\right)$, Akt-kinase, extracellular response kinase (ERK) and mitogen activated protein kinase (MAP), as well as small $G$ proteins (Rho and Rac) (Chan et al., 2002).

To date, the mechanisms which underlie the effects of menstrual effluent on mesothelial cells are not known. Therefore, we investigated whether the morphological changes in mesothelial cells induced by shed menstrual effluent can be characterized as EMT. To this end, it was evaluated whether the morphological changes are reversible, energy dependent, result from kinase-dependent remodeling of the cytoskeleton (Kellie et al., 1991; Boyer et al., 2000; Timpson et al, 2001; Frame et al, 2002), and involve changes in the expression of Snail, E-cadherin, vimentin and cytokeratin.

\section{Materials and Methods}

\section{Tissue}

The use of human tissue in this study was approved by the Medical Ethical Committee of the Academic Hospital Maastricht, and all women signed a written informed consent.

Human omentum $(n=8)$ was obtained from female patients undergoing abdominal surgery for benign indications. Anterogradely shed menstrual effluent $(n=60)$ was collected by healthy volunteers $(n=11)$ who had no history of endometriosis and had a regular ovulatory cycle. The donors collected menstrual effluent in a menstrual cup (Keeper, The Hague, The Netherlands) for 3 hours (Koks et al., 1997). Peripheral blood sera were collected from the same individuals. 


\section{Mesothelial cell isolation and culture}

Isolation of human omental mesothelial cells (HOMEC) and preparation of conditioned media were performed as described in a previous report (Demir Weusten et al., 2000). Briefly, the omental tissue was minced and incubated with collagenase $(2 \mathrm{mg} / \mathrm{ml}$, ICN Biochemicals B.V., Zoetermeer, The Netherlands) in routine medium (Dulbecco's modified Eagle's medium; DMEM/Ham's F-12 supplemented with 10\% fetal calf serum, penicillin $100 \mathrm{IU} / \mathrm{ml}$, streptomycin $100 \mu \mathrm{g} / \mathrm{ml}$ and L-glutamine $2 \mathrm{mM}$, amphotericin $0.25 \mathrm{\mu g} / \mathrm{ml}$, all from Gibco Life Technologies, Breda, The Netherlands) for 20 minutes at $37^{\circ} \mathrm{C}$. The nondigested tissue was removed by a $400 \mu \mathrm{m}$ stainless sieve (Sigma-Aldrich Chemie B.V., Zwijndrecht, The Netherlands). Subsequently, the cell suspension was sieved through a $100 \mu \mathrm{m}$ nylon mesh filter (Micronic, Lelystad, The Netherlands) and a 10 um polyamide filter (Stokvis \& Smits, IJmuiden, The Netherlands). The cells retained on both of these filters were resuspended in culture medium (Minimum essential medium; MEM/D-valine supplemented with 10\% fetal calf serum, 1\% ITS (insulin, transferrin and selenium), nonessential amino acids, L-glutamin $2 \mathrm{mM}$, penicillin $100 \mathrm{IJ} / \mathrm{ml}$, streptomycin $100 \mathrm{\mu g} / \mathrm{ml}$ and amphotericin $0.25 \mu \mathrm{g} / \mathrm{ml}$ ). Culture medium was from Sigma-Aldrich Chemie B.V. Remaining contaminating stromal cells were separated from mesothelial cells by differential plating. After 30 minutes of incubation at $37^{\circ} \mathrm{C}$, the non-adhering cells were collected and placed in a new flask.

The mesothelial cells are cultured in MEM/D-valine medium, which suppresses the growth of fibroblasts. The cells in the cultures are all positive for both cytokeratin and vimentin and negative for the endothelial marker CD34, as was shown previously (Demis Weusten et al, 2000). Confluent HOMEC cultures from passage two were used in the experiments.

\section{Preparation of menstrual serum, conditioned media}

After collection, the menstrual effluent was centrifuged at $1200 \mathrm{~g}$ for 10 minutes. The serum was stored and referred to as menstrual serum. The remaining tissue was immediately resuspended in routine medium $(1: 7 \mathrm{~V} / \mathrm{V})$, layered on a Histo-Paque 1077 gradient (Sigma-Aldrich Chemie B.V.) and centrifuged at $1200 \mathrm{~g}$ for 30 minutes. Endometrial and inflammatory cells were collected from the interphase, washed and cultured in routine medium for 24 hours at $37^{\circ} \mathrm{C}$ and $5 \% \mathrm{CO}_{2}$. After culture, the medium was removed and centrifuged at $1500 \mathrm{~g}$ for 10 minutes. This supernatant was referred to as conditioned medium. Sera and conditioned media prepared from different individuals were pooled ( $n=10$ and $n=12$, respectively), filter-sterilized and stored at $-80^{\circ} \mathrm{C}$ until use. Unless it is indicated, pooled sera or pooled conditioned media were used in all of the experiments. 


\section{Induction of morphological transitions in HOMEC}

Mesothelial cells were grown in 24-well plates until confluence and subsequently cultured overnight in one of the above mentioned sera and media preparations. Mesothelial cells cultured in peripheral blood sera and routine medium served as controls for the changes in cell morphology. Prior to use in the experiments sera were diluted with routine medium $(\mathrm{I}: 1 \mathrm{v} / \mathrm{v})$. To test whether the morphological changes were reversible, sera and media were replaced with fresh routine medium and the cultures were continued for 4 days. These experiments were repeated 12 times.

\section{Visualization of morphological transition with time-lapse video imaging}

Confluent HOMEC monolayers were prepared in 6-well plates which were placed between temperature control plates on a translucent thermo-stage and viewed with a Leica MZFLIII stereomicroscope, equipped with a Donpisha 3-CCD camera. The dish was obliquely transilluminated. Cells were cultured in routine medium or conditioned media. HEPES (45 mM, Gibco Life Technologies) was added to the cultures to compensate for any $\mathrm{pH}$ changes in the media. Digital images were prepared every 2 minutes for a period of 20 hours and simulated into a video film using Fast Movie Processor 1.44 software.

\section{MTt assay}

Effects of conditioned media on the viability of mesothelial cells were determined using the MTT assay. Viable cells convert the soluble substrate MTT to an insoluble, coloured formazan salt. After culturing confluent HOMEC monolayers overnight with either routine medium or conditioned media, cells were rinsed once with routine medium. Then $400 \mu \mathrm{l}$ routine medium and $60 \mu$ of MTT [3(4,5-dimethylthiazolyl-2)-2,5-diphenyl-2H-tetrazolium bromide, Sigma-Aldrich Chemic B.V.] were added to each well of a 24-well plate. After 4 hours of incubation at $37^{\circ} \mathrm{C}$, the supernatant was removed and the formazan salt was solubilized in 200 ul DMSO (Merck, Amsterdam, The Netherlands), which resulted in a purple coloured solution. The amount of formazan formed was quantified by measuring the optical density at $550 \mathrm{~nm}$.

\section{Immunohistochemistry}

Mesothelial cell monolayers were incubated overnight in routine medium or conditioned media. The morphological changes in cells were characterized by conventional light and immunofluorescence microscopy. A fluorescein isothiocyanate-conjugated secondary antibody (goat anti-mouse IgG, diluted 1:20, from DAKO, A/S, Glastrup, Denmark) was used to visualize the primary antibodies, which were directed to cytoskeletal proteins to detect 
the changes in cell architecture. These antibodies were a pan-cytokeratin antibody against cytokeratins 5, 6, 8, 17, 19 (diluted 1:100, MNF1 16, from DAKO A/S), an $\alpha$-tubulin antibody (1:400, Sigma-Aldrich Chemie B.V.). A direct rhodamine-conjugated phalloidin method was used for fibrillar actin (Friedman et al., 1984). In the negative controls the primary antibodies were omitted from the incubation solution.

\section{Blocking of energy supply and signaling pathways}

To test whether the energy supply of mesothelial cells is related to the morphological changes, sodium azide was added to the routine and conditioned media. Sodium azide inhibits haem-containing proteins, including the cytochromes in mitochondria which are responsible for ATP production, thus blocking the cellular energy supply (Bershadsky and Gelfand, 1981). During the overnight incubation the routine and conditioned media were supplemented with $0.1 \%$ sodium azide.

To evaluate the involvement of kinases in the morphological remodeling of mesothelial cells, HOMEC were incubated overnight in routine or conditioned media in 24-well plates, in the presence or absence of kinase inhibitors. The inhibitors used and their concentrations are listed in Table 1. Prior to overnight incubation, HOMEC were preincubated for 30 minutes in routine medium with vehicle or the inhibitor of interest.

\begin{tabular}{|c|c|c|}
\hline Name & Inhibitory action & Concentrations tested \\
\hline $\begin{array}{l}\text { Wortmannin } \\
\text { (Calbiochem) }\end{array}$ & $\begin{array}{l}\text { phosphatidylinositol } 3 \text {-kinase }\left(\mathrm{Pl}_{3}-\bar{K}\right) \\
\text { and myosin light chain kinase }\end{array}$ & $\begin{array}{l}7.5,15,30,60,125,250 \\
500 \mathrm{nM}, 1,2,4 \mu \mathrm{M}\end{array}$ \\
\hline $\begin{array}{l}\text { Genistein } \\
\text { (Sigma) }\end{array}$ & protein tyrosine kinases & $\begin{array}{l}7.5,15,30,60,125,250 \\
500 \mu \mathrm{M}, 1 \mathrm{mM}\end{array}$ \\
\hline $\begin{array}{l}\text { SU } 6656 \\
\text { (Calbiochem) }\end{array}$ & src family kinases (src, fyn, yes, lyn) & $\begin{array}{l}10,100,250,500,750 \mathrm{nM} \\
1,5,10 u \mathrm{M}\end{array}$ \\
\hline
\end{tabular}

Table 1: Kinase inhibitors used in this study.

\section{RNA isolation and complementary DNA synthesis}

HOMEC were cultured overnight either in routine medium or in conditioned media ( $n=7)$. After removal of the medium total RNA was extracted and purified using TRIZOL reagent, according to the instructions of the manufacturer (Gibco Life Technologies). Total RNA ( 1 ug) was incubated with random hexamers ( $1 \mu g / \mu l_{t}$ Promega, USA) at $70^{\circ} \mathrm{C}$ for 10 minutes. The 
samples were chilled on ice for 5 minutes. To this, a reverse transcriptase (RT)-mix consisting of $5 \times$ RT-buffer $(4 \mu \mathrm{l}), 10 \mathrm{mM}$ dNTP mix ( $1 \mu \mathrm{l})$ (Pharmacia, Uppsala, Sweden), $0.1 \mathrm{M}$ dithiothrietol $(2 \mu \mathrm{l})$ and superscript II reverse transcriptase $(200 \mathrm{lU} / \mu \mathrm{l})$ was added and the samples were incubated at $42^{\circ} \mathrm{C}$ for 1 hour. The reverse transcriptase was inactivated by heating the samples at $95^{\circ} \mathrm{C}$ for 5 minutes. The CDNA was stored at $-20^{\circ} \mathrm{C}$ until further use. In each real-time RT-PCR reaction 50 ng of CDNA template was used.

\section{Real-time RT-PCR for Snail, E-cadherin and vimentin expression}

Primers and probes for human Snail, E-cadherin, vimentin and cyclophylin A were purchased from the manufacturer as pre-developed assays (Perkin-Elmer Applied Biosystems, Foster City, CA, USA). Human cyclophylin A was selected as an endogenous RNA control to normalize for the differences in the amount of total RNA added to each reaction. Human endometrial tissue was used as a positive control in real-time RT-PCR amplifications.

All RT-PCR reactions were performed using an ABI Prism 7700 sequence detection system (Perkin-Elmer Applied Biosystems). The thermal cycling conditions comprised an initial decontamination step at $50^{\circ} \mathrm{C}$ for 2 minutes, a denaturation step at $95^{\circ} \mathrm{C}$ for 10 minutes and 40 cycles at $95^{\circ} \mathrm{C}$ for 15 seconds and $60^{\circ} \mathrm{C}$ for 1 minute. Experiments were performed in duplicate for each sample. Quantitative values were obtained from the threshold cycle number $(\mathrm{Ct})$ at which the increase in the signal associated with exponential growth of RT-PCR products is first detected with the ABI Prism 7700 sequence detector software (Perkin-Elmer Applied Biosystems). The fold-change in expression was calculated using the $\Delta \Delta \mathrm{Ct}$ method with the cyclophylin A mRNA as an internal control (for details see user bulletin \#2 for the ABI PRISM 7700 Sequence Detection System, available at http://www.ukl.uni-freiburg.de/core-facility/tagman/user_bulletin_2.pdf).

\section{Electrophoresis and Western blotting of E-cadherin, vimentin and cytokeratin}

Confluent monolayers of HOMEC were cultured overnight, either in routine medium or in conditioned media. After rinsing cells several times with DMEM, cells were lysed in lysis buffer, containing $20 \mathrm{mM}$ Tris $\mathrm{HCl}, \mathrm{pH} 8,137 \mathrm{mM} \mathrm{NaCl}, 1 \mathrm{mM} \mathrm{MgCl}, 1 \mathrm{mM} \mathrm{CaCl}, 10 \%$ glycerol, $1 \%$ Triton X-100, $1 \mathrm{mM}$ phenyl methylsulphonyl fluoride and protease inhibitor cocktail (Boehringer, Almere, The Netherlands). Unsolubilized cell rests were pelleted, the supernatants were stored at $-80^{\circ} \mathrm{C}$ for later use. Protein concentrations were determined with the bicinchoninic acid assay (BCA assay, Sigma-Aldrich).

After the proteins ( $15 \mu \mathrm{g} /$ lane) had been electrophoretically separated on a $10 \%$ sodium dodecyl sulphate-polyacrylamide gel, they were transferred to a nitrocellulose membrane (Schleicher and Schuell, Den Bosch, The Netherlands). The membranes were stained with Ponceau $S$ to evaluate whether the proteins were equally loaded. Non-specific binding sites were blocked with 5\% non-fat dry milk in PBS containing 0.05\% Tween 20 (PBST), overnight 
at $4^{\circ} \mathrm{C}$. After washing three times 5 minutes with PBST, the blot membrane was incubated with anti-E-cadherin (diluted 1:500, Santa Cruz Biotechnology, CA, USA), anti-vimentin (diluted 1:2000, Cappel, Organon Teknika, Durham, NC, USA), and anti-pan-cytokeratin, against cytokeratins 5, 6, 8, 17, 19 (diluted 1:2000, MNF116, DAKO A/S), for 1 hour at room temperature. At the end of this period the blot membrane was washed three times for 5 minutes in PBST and then incubated with horseradish peroxidase-conjugated rabbit antimouse IgG (diluted 1:1000, DAKO A/S) for 1 hour at room temperature. The antibodies were detected by enhanced chemiluminescene using SuperSignal West Pico Chemiluminescent Substrate (Pierce, IL, USA). The bands were analysed using Kodak X-OMAT film.

\section{Results}

Culturing mesothelial cells with menstrual sera as well as with media conditioned by shed menstrual cells resulted in morphological changes of these mesothelial cells from an epithelial-like to a fibroblast-like shape (Figure $1 a-d$ ). When menstrual sera and conditioned
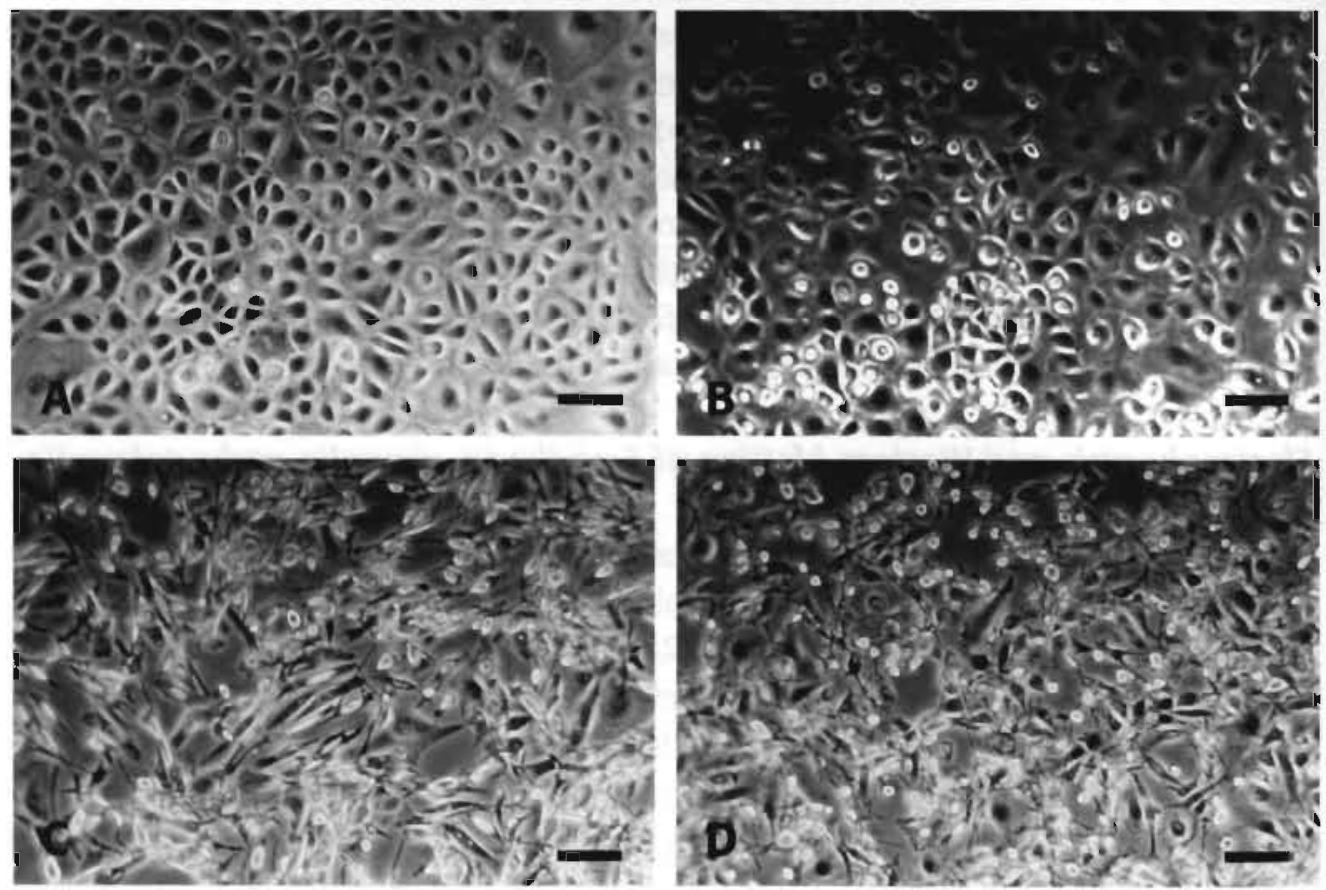

Figure 1: Epithelial to mesenchymal transitions of cultured mesothelial cells induced by menstrual sera and conditioned media. (a) Routine medium, (b) peripheral blood sera, (c) menstrual sera, (d) conditioned media prepared from cells isolated from shed menstrual effluent. Scale bars represent $100 \mathrm{um}$. 
media were removed and the cultures were continued in routine medium for another 4 days, the typical mesothelial morphology was restored (Figure 2a-c). Cell viability, as measured with the MTT assay, was not different for cells cultured in routine medium and in conditioned media.
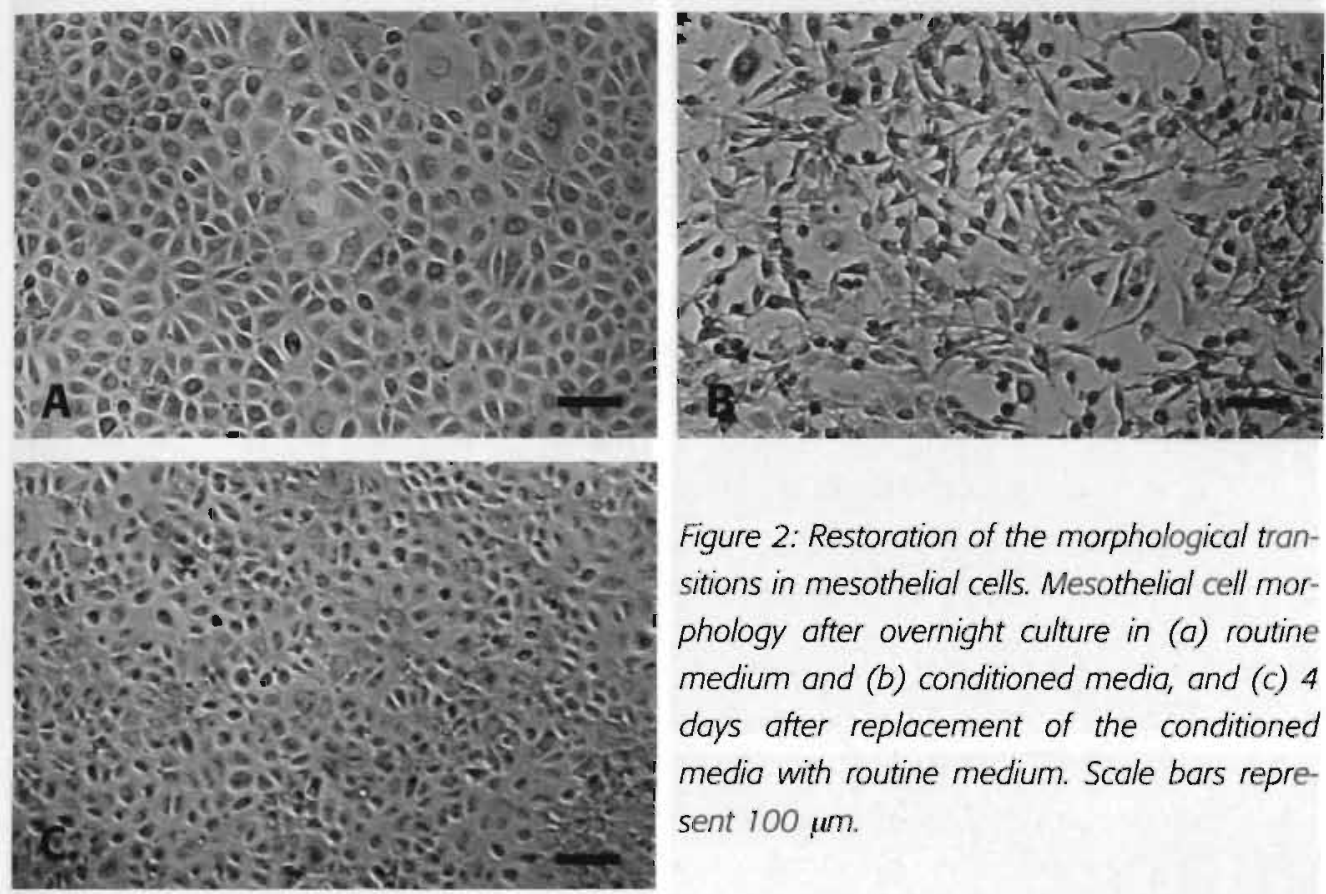

Figure 2: Restoration of the morphological transitions in mesothelial cells. Mesothelial cell morphology after overnight culture in (a) routine medium and (b) conditioned media, and (c) 4 days after replacement of the conditioned media with routine medium. Scale bars represent $100 \mu \mathrm{m}$.

Time-lapse video microscopy of confluent HOMEC monolayers showed that culture in the presence of conditioned media caused disruption of cell-cell contacts between the mesothelial cells, and led to increased occurrence of membrane ruffling, which gave rise to formation of lamellipodia and filapodia. At the end of the experiment, i.e. after 20 hours of culturing, the cells had lost their well-spread morphology and became refractile elongated cells, with stellate, spindle or fibroblast-like appearances, and demonstrated increased motility. These changes were not observed in control routine medium. Time-lapse videos are presented at the website: http://www.grow.unimaas.n//biology_merg_movies.htm.

Immunostainings with antibodies to pan-cytokeratin, fibrillar actin and $\alpha$-tubulin showed a change in the localization of these cytoskeletal proteins as an effect of conditioned media (Figure 3). In control cultures cytokeratin filaments were found condensed around the nucleus of mesothelial cells, forming "bird nests" (Figure 3a), whereas after culture in conditioned media the cytokeratin filaments were concentrated in the spindles and extensions (Figure 3b). Fibrillar actin staining was concentrated at the periphery of the cells in control cultures (Figure 3c). After culturing the cells in conditioned media, fibrillar actin was distributed throughout the cytoplasm (Figure $3 d$ ). $\alpha$-Tubulin staining highlighted the pres- 

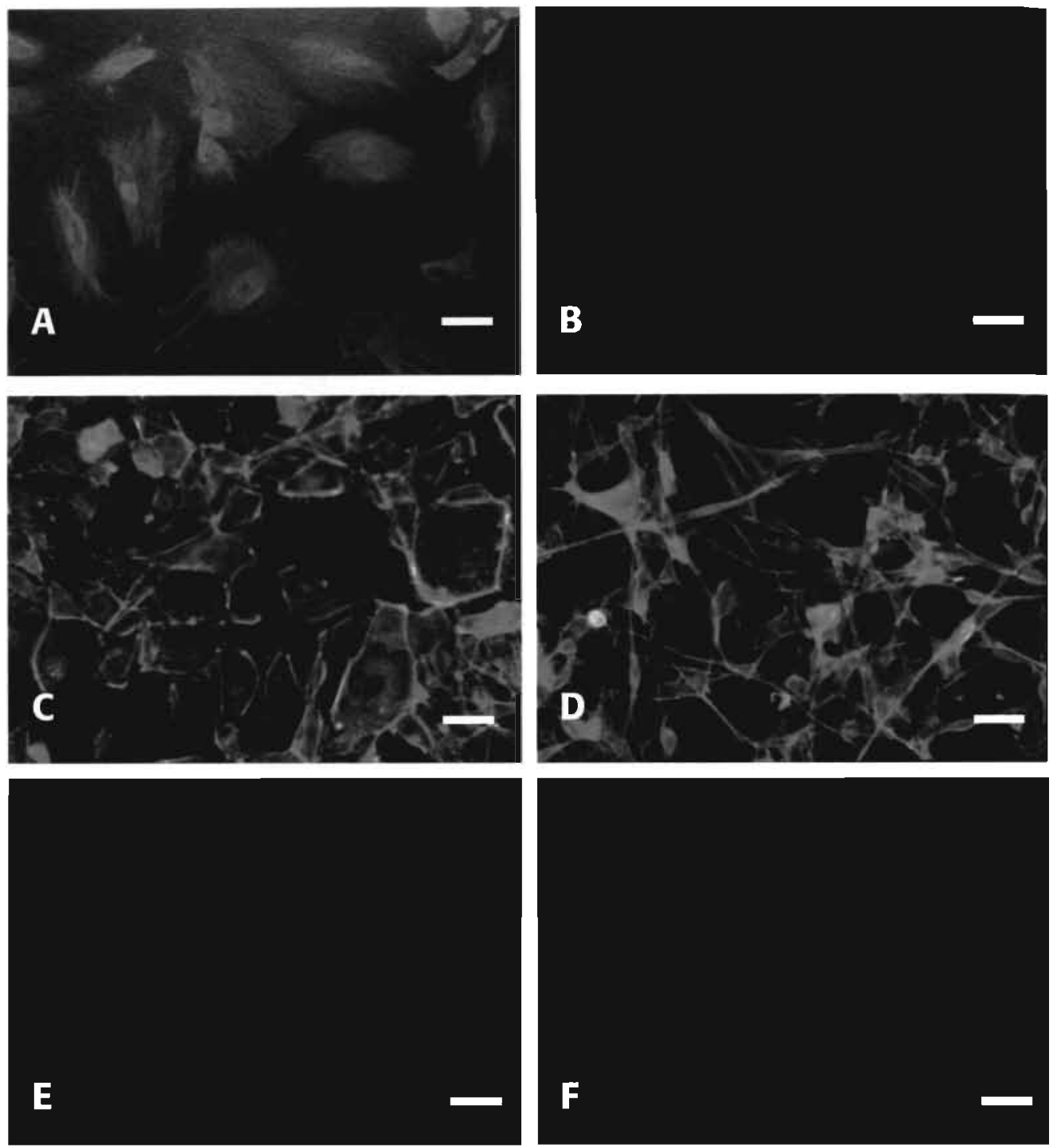

Figure 3: Cytoskeletal rearrangements in mesothelial cells after overnight culture in conditioned medium. $(a, c, e)$ Cells cultured in routine medium, $(b, d, f)$ cells cultured in conditioned medium. The cells are stained for cytokeratin filaments $(a, b)$, actin filaments ( $c, d)$, and a-tubulin microtubules (e, f). Scale bars represent $40 \mu \mathrm{m}$.

ence of a normal microtubule network that extended throughout the cytoplasm of mesothelial cells which were cultured in routine medium (Figure 3e). After incubation in conditioned media, the microtubule network depolymerized as shown by homogenous, non-fibrous nature of $\alpha$-tubulin staining in morphologically changed cells (Figure $3 f$ ). 
Addition of sodium azide to the conditioned media prevented the morphological alterations in mesothelial cells which were induced by conditioned media from menstrual effluent (Figure 4)
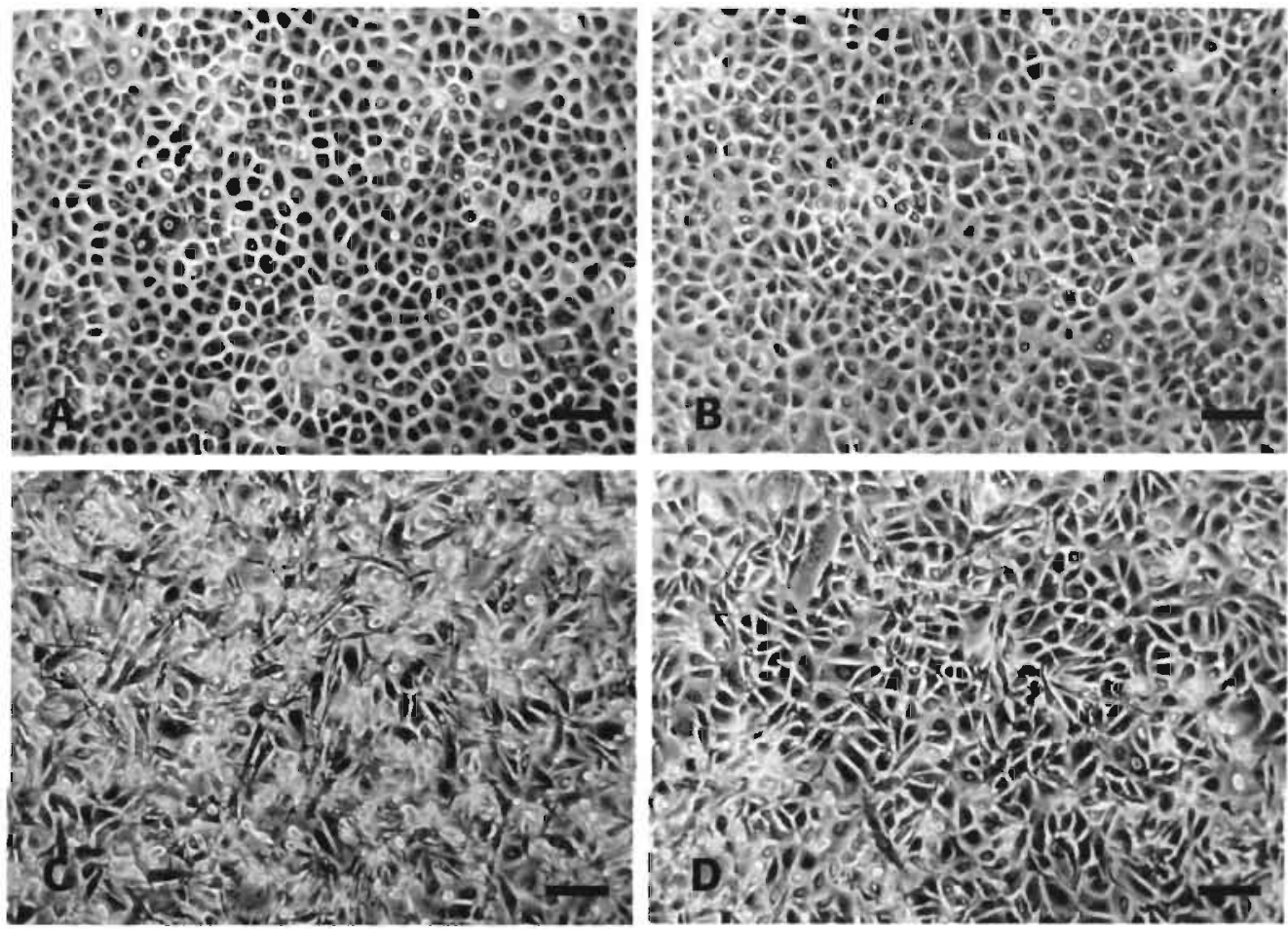

Figure 4: Sodium azide prevents epithelial to mesenchymal transitions in mesothelial cells induced by conditioned media. (a) Routine medium, (b) routine medium supplemented with sodium azide, (c) conditioned media, (d) conditioned media supplemented with sodium azide. Scale bars represent $100 \mu M$.

Genistein was toxic to mesothelial cells at the higher concentrations used ( $500 \mu \mathrm{M}$ and $1 \mathrm{mM})$, whereas SU 6656 did not show any toxicity at all. The toxicity was morphologically evaluated by using light microscopy. Genistein was effective in preventing the morphological alterations induced by conditioned medium at $125 \mu \mathrm{M}$ and $250 \mu \mathrm{M}$ concentrations (Figure 5). At the highest concentrations used, SU 6656 was also a potent inhibitor of the effects of conditioned medium, however, the reversal was not as complete as observed for Genistein (Figure 5). Wortmannin was toxic at the highest dose (4 $\mu \mathrm{M})$. At lower dosages Wortmannin prevented the morphological changes induced by conditioned media, but not completely (Figure 5). 


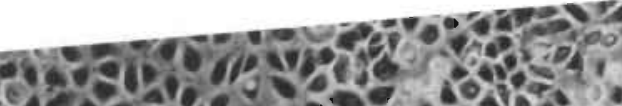

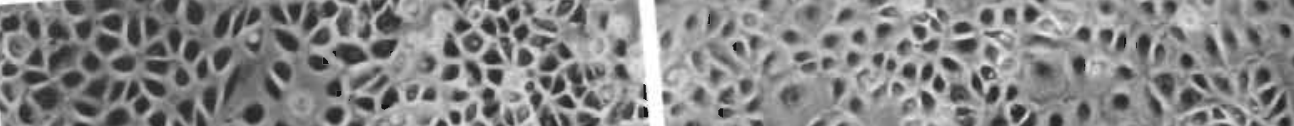

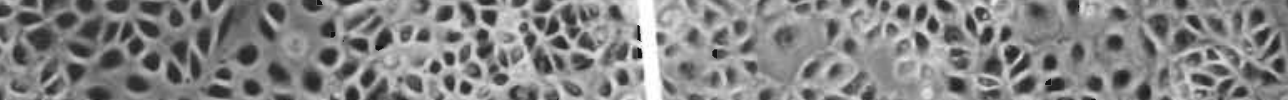

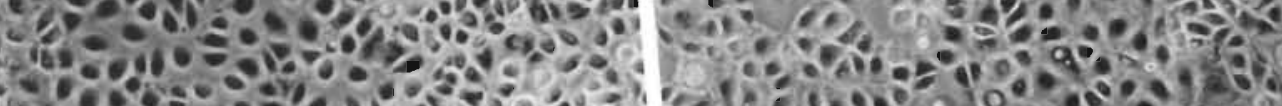

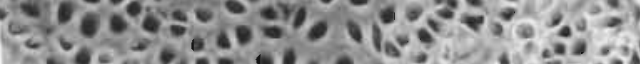
is

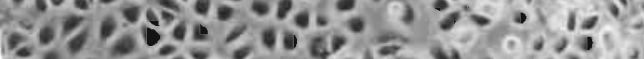

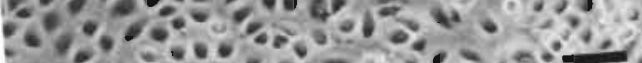

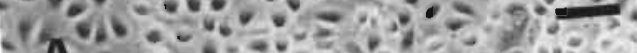

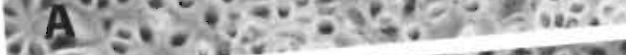

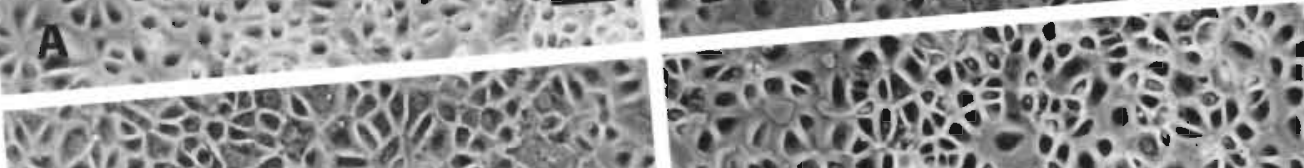

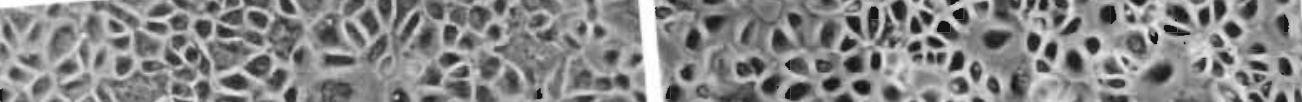

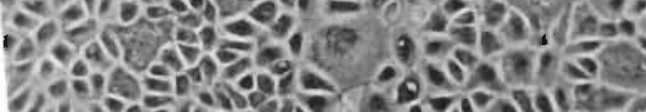

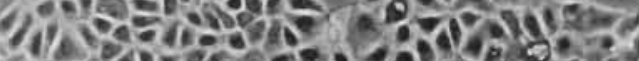

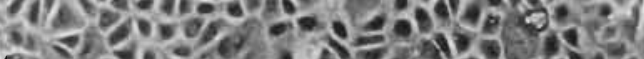
Q.

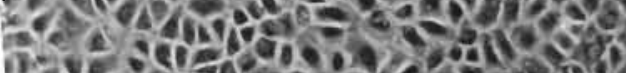

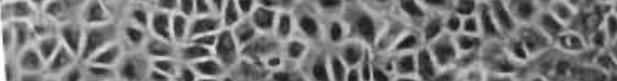
19:-

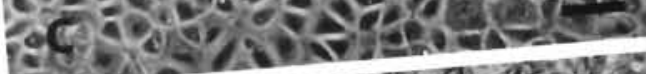

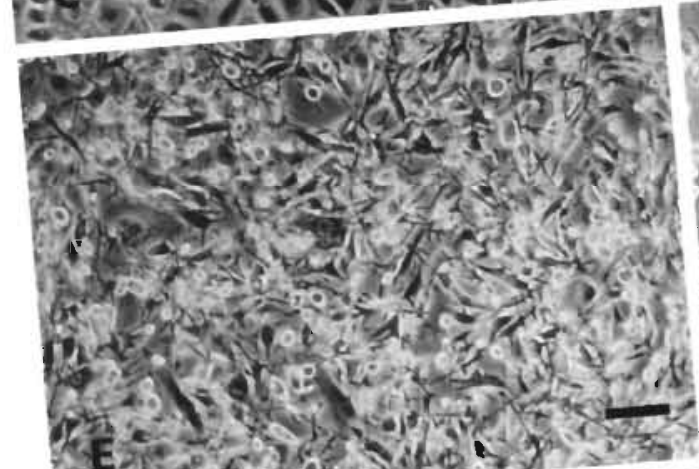

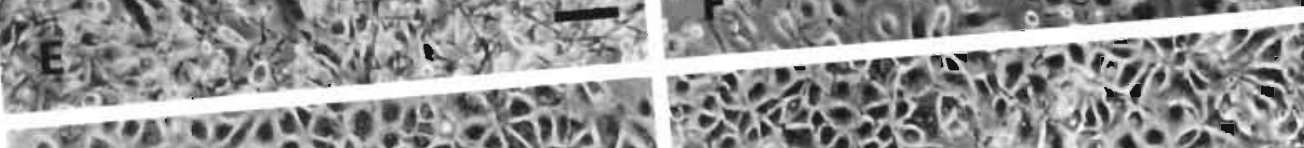
s.

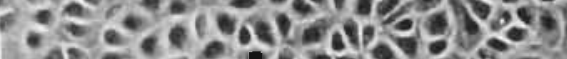

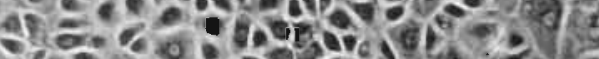

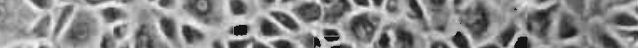

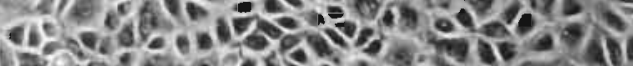

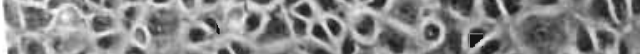

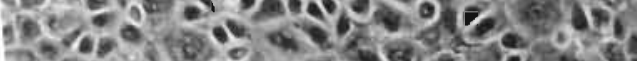

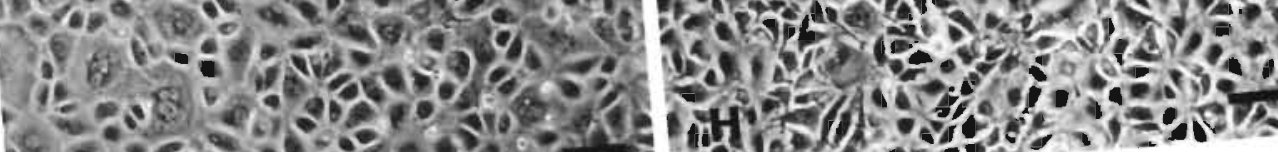

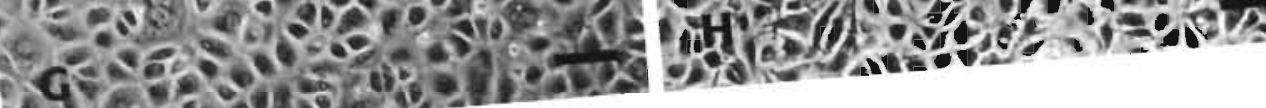

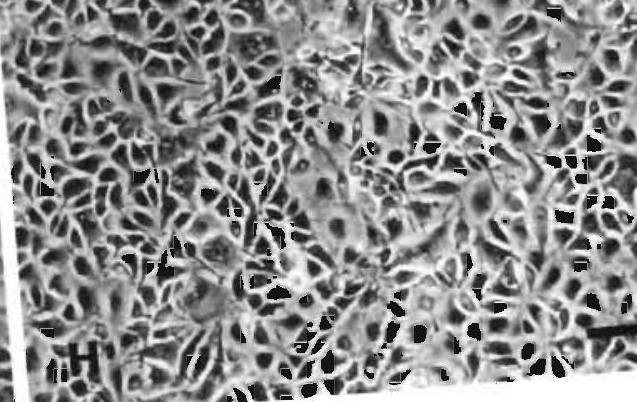

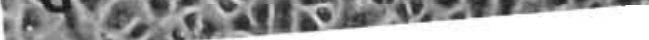

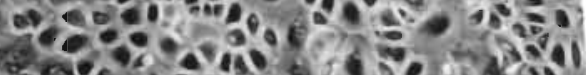

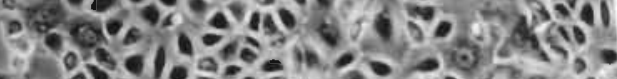

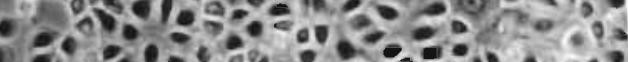

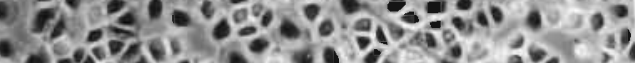
c-

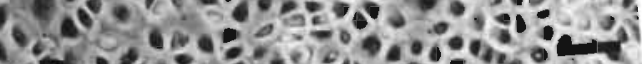

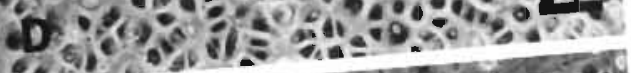
32 a i.

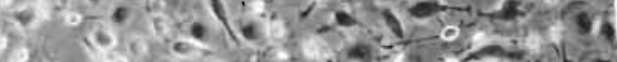

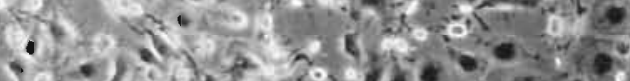

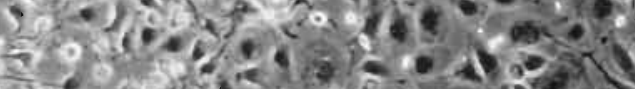

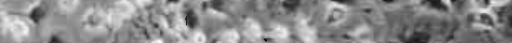

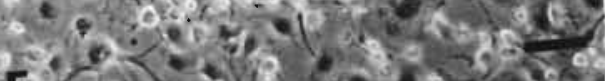

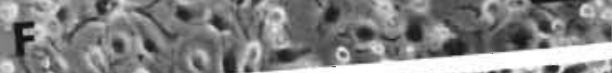
-jolivara alare. 
Figure 5: Effects of kinase inhibitors on conditioned medium-induced epithelial to mesenchymal transitions in mesothelial cells. (a-d) Routine medium (a), supplemented with (b) Wortmannin, (c) Genistein, (d) SU 6656. (e-f) Conditioned medium (e), supplemented with (f) Wortmannin, (g) Genistein, (h) SU 6656. Scale bars represent $100 \mathrm{um}$.

All conditioned media tested induced mesothelial cell remodeling and concomitantly mRNA expression of Snail and vimentin in mesothelial cells, whereas E-cadherin mRNA levels were reduced (Figure 6). Furthermore, the expression of vimentin protein was increased and the expression of E-cadherin protein was reduced after culture in conditioned media compared with culture in routine medium (Figure 7). Western blot analysis with pan-cytokeratin antibody revealed alterations in the expression patterns of acidic type cytokeratins $(<55 \mathrm{kD})$ as well as heterodimers of acidic and basic type cytokeratins in mesothelial cells after culture in conditioned media (Figure 7).

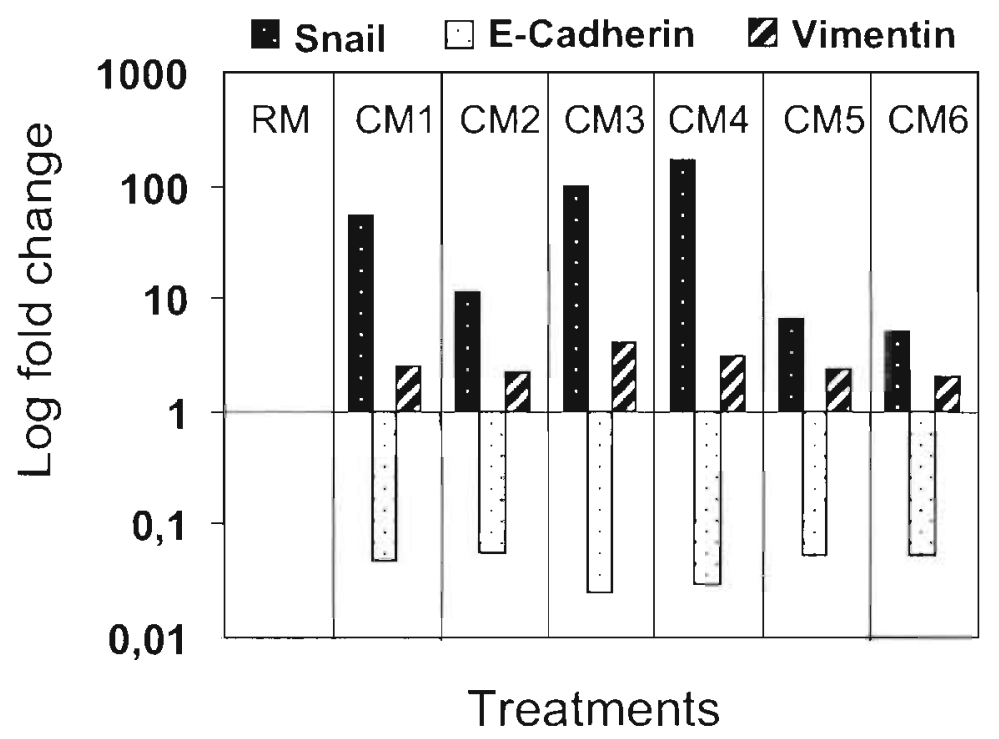

Figure 6: Snail, E-cadherin and vimentin mRNA levels in mesothelial cells after overnight culture in routine medium (RM) and conditioned media (CM). Since the expression levels of Snail are much larger compared to vimentin and E-coudherin, expression levels are presented as the logarithm of the fold change induced by conditioned media compared with the levels induced by routine medium. 
A

RM CM

\section{Ponceau}

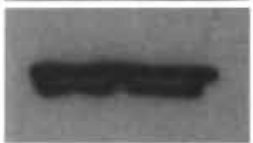

B-actin
B

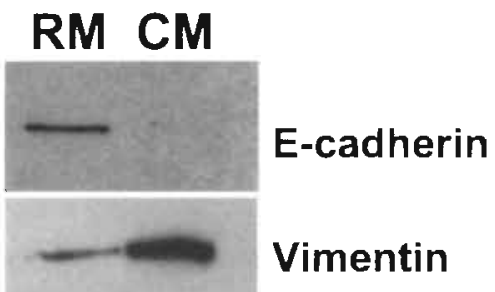

98

64

50

Pan-cytokeratin

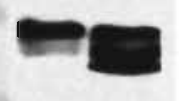

\section{.}

Figure 7: Western blot analysis of E-cadherin and vimentin protein expression in mesotheliol cells. after overnight culture in routine medium (RM) or conditioned media (CM). (A) Blots were stained with Ponceau $S$ and $\beta$-actin to control for equal looding. (B) After culture in conditioned medium, E-cadherin expression was reduced, whereas vimentin expression was enhanced. Changes in the expression pattern of various cytokeratins were also obsened.

\section{Discussion}

Conditioned media prepared from cells isolated from menstrual effluent, induced morphological alterations in mesothelial cells in vitro. The typical epithelial-like polygonal morphology of the mesothelial cells changed into a fibroblast-like morphology. Cells dissociated from each other and cell movements increased, as was revealed by time-lapse video microscopy. The effects were fully reversed when the conditioned media were replaced with routine medium and culture was continued for another 4 days.

Similarly, reversible changes in cell morphology have been described as a process called cell scattering, associated with EMT (Boyer et al., 1989; Hay, 1995; Boyer et al., 1996). The loss of cell-cell cohesion, presumably due to damaged intercellular junctions and increased cell motility, strongly suggests concomitant changes in the cytoskeleton and this was indeed observed. The changes in immunofluorescence staining of cytokeratin, actin filaments, and $\alpha$-tubulin demonstrated marked cytoskeletal rearrangements, whereas the MTT assay showed no change in cell viability. Also, the process was found to be reversible. These observations are consistent with our earlier findings (Demir Weusten et al., 2000), 
and provide evidence that the morphological alterations in mesothelial cells are not the result of an increase in the number of dying cells, but of cytoskeletal remodeling.

Sodium azide antagonized the EMT-inducing effects of conditioned medium. This compound inhibits haem-containing proteins, such as cytochromes in mitochondria which are responsible for ATP production, thus blocking the cellular energy supply (Vanzetti, 1966; Bershadsky and Gelfand, 1981). In other studies sodium azide has also been shown to prevent the induced disassembly of microfilaments and microtubules (Ma et al., 1995). Apparently, depletion of the ATP pool interferes with ATP-dependent processes like the phosphorylation of proteins (Wang, 1991), which will prevent the cytoskeletal reorganization. The characteristics of this process, including the reversibility, are consistent with EMT (Boyer et al., 1989; Mutsaers, 2002).

The EMT are a consequence of the activation of signaling cascades through membraneassociated proteins (Boyer et al., 2000). Extracellular matrix components such as collagen, as well as soluble factors, including EGF, HGF/SF, members of the FGF and TCF- $\beta$ families, have been shown to be directly involved in the induction of EMT (Savagner, 2001). So far, few studies have been performed on EMT in mesothelial cells, and TGF- $\beta$ (Yang et al., 2003), TNF- $\alpha$ (Zhu et al., 2002) and HGF/SF (Rampino et al., 2001) have been implicated in EMT. Yang and coworkers reported similar cytoarchitectural changes of mesothelial cells as a result of continuous incubation for 7 days with TCF- $\beta$ (Yang et al., 2003). The mesothelial cells maintained their fibroblastic phenotype despite the withdrawal of TCF- $\beta$. In the current study the changes were reversible and occurred within 18 hours. It is therefore not likely that these changes are mediated by TCF- $\beta$. Tumour necrosis factor- $\alpha$ (TNF- $\alpha$ ) and HCF/SF are likely candidates and their role in this process is currently under investigation.

The induction of EMT involves the Src tyrosine kinase and Ras signaling pathways. Ras functions by activating MAP kinase and $\mathrm{Pl}_{3} \mathrm{~K}$ signaling pathways (Boyer et al., 1997; Potempa and Ridley, 1998), whereas Src tyrosine kinases phosphorylate adhesion kinase in cellular focal adhesion points, which results in focal adhesion loss during transformation (Fincham and Frame, 1998; Chaudhary et al., 2002).

Genistein, a general protein tyrosine kinase inhibitor, fully antagonized the EMT-inducing effects of conditioned media. This indicates that tyrosine kinases are essential mediators in EMT induction. However, the Src family protein tyrosine kinase inhibitor, SUI 6656, was not able to fully antagonize the EMT-inducing properties of conditioned medium, indicating that other mechanisms may be involved. This is supported by the fact that Wortmannin, a $\mathrm{PI}_{3} \mathrm{~K}$ inhibitor, was able to partially prevent $\mathrm{EMT}$. These findings indicate that Ras and Src tyrosine kinases signaling pathways are involved in EMT induction in mesothelial cells by menstrual effluent. This is consistent with studies on the characterization of EMT in other cell types (Kellie et al., 1991; Hay and Zuk, 1995; Thomas et al., 1995; Gelman et al., 1998; Timpson et al., 2001; Frame, 2002; Frame et al., 2002).

The transcription factor Snail plays a key role in triggering EMT in Drosophila and cultured epithelia (Alberga et al., 1991; Batlle et al., 2000; Cano et al., 2000). Parallel to 
these reports, the present study provides evidence that the up-regulation of Snail in mesothelial cells that are cultured in conditioned media is associated with the acquisition of a fibroblastoid phenotype. One of the direct targets of Snail is the promoter of E-cadherin. Snail directly represses E-cadherin promoter activity and E-cadherin expression (Batlle et al., 2000; Cano et al, 2000). When the mesothelial cells were cultured in conditioned media, E-cadherin mRNA expression was down-regulated and E-cadherin protein could no longer be detected. This will result in a disturbance of epithelial cell organization, probably due to a loss of cell-cell contacts. In addition, during this process vimentin expression was strongly increased in the mesothelial cells. This appears to be mandatory to start EMT in mesothelial cells, since it is well known that many transforming epithelia change their intermediate filaments from cytokeratin to vimentin (Greenburg and Hay, 1988). In the mesothelial cells, cytokeratin expression was also markedly altered.

Recently, transition of peritoneal mesothelial cells from an epithelial to mesenchymal phenotype was shown to be induced in vivo and ex vivo when these cells were subjected to continuous peritoneal dialysis (Yanez-Mo et al., 2003). The authors suggested that long term exposure of the mesothelial cells to the irritating dialysis solutions may lead to complete transition of the mesothelial cells, which could be responsible for tissue fibrosis and failure in ultrafiltration. Patients undergoing continuous ambulatory peritoneal dialysis have an incrused risk of the intra-abdominal spread of tumour cells compared to non-dialysis patients (Bargman, 2000). This indicates that the mesothelium serves as an effective barrier against the adhesion of cells. Our earlier findings that endometrial fragments preferably adhere to damaged areas with exposed submesothelial structures (Groothuis et al., 1998; Koks et al., 1999), confirm this.

Based on the evidence provided in this study, we conclude that the morphological alterations induced by factors released from shed menstrual effluent induce EMT. The implication for the clinic is that larger amounts of retrogradely shed menstrual effluent and a longer exposure to this effluent, will likely lead to a greater insult for the mesothelium and an increased adhesion of retrogradely shed menstrual endometrial tissue. This is supported by the increasing risk for endometriosis when (retrograde) blood flow is heavier and the menstrual periods are longer (Sanfilippo et al., 1986; Darrow et al., 1993; Eskenazi and Warner, 1997).

\section{Acknowledgements}

We acknowledge ing. Christa de Veen and ing. Natasja Kisters for their expert technical support, Dr. Henny van Straaten and Mr. Johan Hekking (Department of Anatomy and Embryology, Maastricht University) for their assistance in the preparation of video images, Prof. Dr. F.C.S. Ramaekers (Department of Molecular and Cellular Biology, Maastricht University) for donating rhodamine-conjugated phalloidin. 


\section{References}

Alberga, A., Boulay, J. L., Kempe, E., Dennefeld, C. and Haenlin, M. (1991) The snail gene required for mesoderm formation in Drosophila is expressed dynamically in derivatives of all three germ layers. Development, 111, 983-982.

Andreoli, S. P. Mallett, C., Williams, K., McAteer, J. A., Rothlein, R and Doerschuk, C. M. (1994) Mechanisms of polymorphonuclear leukocyte mediated peritoneal mesothelial cell injury. Kidney Int, 46, $1100-1109$.

Bargman, J. M. (2000) Neoplasia in dialysis patients: pathophysiology, epidemiology, and screening. Adv Perit Dial, 16, 93-96.

Batlle, E., Sancho, E., Franci, C., Dominguez, D., Monfar, M., Baulida, J. and Garcia De Herreros, A. (2000) The transcription factor snail is a repressor of E-cadherin gene expression in epithelial tumour cells. Nat Cell Biol, 2, 84-89.

Bershadsky, A. D. and Gelfand, V. I. (1981) ATP-dependent regulation of cytoplasmic microtubule disassembly. Proc Natl Acad Sci USA, 78, 3610-3613.

Boury, N. D., Marquet, R. L., Jeekel, H. and Bonjer, H. J. (1996) Impact of gas(less) laparoscopy and laparotomy on peritoneal tumour growth and abdominal wall metastases. Ann Surg, 224, 694-700.

Boyer, B., Tucker, G. C., Valles, A. M., Gavrilovic, J. and Thiery, J. P. (1989) Reversible transition towards a fibroblastic phenotype in a rat carcinoma cell line. Int J Cancer Suppl, 4, 69-75.

Boyer, B., Valles, A. M. and Thiery, J. P. (1996) Model systems of epithelium-mesenchyme transitions. Acta Anat, 156, 227-239.

Boyer, B., Roche, S., Denoyelle, M. and Thiery, J. P. (1997) Src and Ras are involved in separate pathways in epithelial cell scattering. Embo J, 16, 5904-5913.

Boyer, B., Valles, A. M. and Edme, N. (2000) Induction and regulation of epithelial-mesenchymal transitions. Biochem Pharmacol, 60, 1091-1099.

Cano, A., Perez-Moreno, M. A., Rodrigo, I., Locascio, A., Blanco, M. J., del Barrio, M. G., Portillo, F. and Nieto, M. A. (2000) The transcription factor snail controis epithelial-mesenchymal transitions by repressing E-cadherin expression. Nat Cell Biol, 2, 76-83.

Chan, T. O., Rodeck, U., Chan, A. M., Kimmelman, A. C., Rittenhouse, S. E., Panayotou, G. and Tsichlis, P. N. (2002) Small GTPases and tyrosine kinases coregulate a molecular switch in the phosphoinositide 3-kinase regulatory subunit. Cancer Cell, 1, 181-191.

Chaudhary, A., Brugge, J. S. and Cooper, J. A. (2002) Direct phosphorylation of focal adhesion kinase by c-Src: evidence using a modified nucleotide pocket kinase and ATP analog. Biochem Biophys Res Commun, 294, 293-300.

Darrow, S. L., Vena, J. E., Batt, R. E., Zielezny, M. A., Michalek, A. M. and Selman, S. (1993) Menstrual cycle characteristics and the risk of endometriosis. Epidemiology, $4,135-142$.

Demir Weusten, A. Y., Groothuis, P. G., Dunselman, G. A., de Goeij, A. F., Arends, J. W. and Evers, J. L. (2000) Morphological changes in mesothelial cells induced by shed menstrual endometrium in vitro are not primarily due to apoptosis or necrosis. Hum Reprod, 15, 1462-1468.

Eskenazi, B. and Warner, M. L. (1997) Epidemiology of endometriosis. Obstet Gynecol Clin North Am, 24, 235-258.

Fincham, V. J. and Frame, M. C. (1998) The catalytic activity of $5 \mathrm{rc}$ is dispensable for translocation to focal adhesions but controls the turnover of these structures during cell motility. Embo J, 17, 81=92.

Frame, M. C. (2002) Src in cancer: deregulation and consequences for cell behaviour. Biochim Biophys Acto, 1602, 114- 130.

Frame, M. C., Fincham, V. J., Carragher, N. O. and Wyke, J. A. (2002) v-Src's hold over actin and cell adhesions. Nat Rev Mol Cell Biol, 3, 233-245.

Friedman, E., Verderame, M., Winawer, S. and Pollack, R. (1984) Actin cytoskeletal organization 
loss in the benign-to-malignant tumour transition in cultured human colonic epithelial cells. Cancer Res, 44, 3040-3050.

Gavrilovic, J., Moens, G., Thiery, J. P. and Jouanneau, J. (1990) Expression of transfected transforming growth factor- $\alpha$ induces a motile fibroblast-like phenotype with extracellular matrix-degrading potential in a rat bladder carcinoma cell line. Cell Regul, 1, 1003-1014.

Gelman, I. H., Lee, K., Tombler, E., Gordon, R. and Lin, X. (1998) Control of cytoskeletal architecture by the src-suppressed C kinase substrate, SSeCKS. Cell Motil Cytoskeleton, 41, 1-17.

Greenburg, G. and Hay, E. D. (1988) Cytoskeleton and thyroglobulin expression change during transformation of thyroid epithelium to mesenchyme-like cells. Development, 102, 605-622.

Groothuis, P. G., Koks, C. A., de Goeij, A. F., Dunselman, G. A., Arends, J. W. and Evers, J. L. (1998) Adhesion of human endometrial fragments to peritoneum in vitro. Fertil Steril, 71, $1119-1124$.

Gutt, C. N., Riemer, V., Kim, Z. G., Erceg, J. and Lorenz, M. (2001) Impact of laparoscopic surgery on experimental hepatic metastases. $\mathrm{Br}$ J Surg, 88, 371-375.

Hay, E. D. (1995) An overview of epithelio-mesenchymal transformation. Acto Anat, 154, 8-20.

Hay, E. D. and Zuk, A. (1995) Transformations between epithelium and mesenchyme: normal, pathological, and experimentally induced. Am J Kidney Dis, 26, 678-690.

Kellie, S., Horvath, A. R. and Elmore, M. A. (1991) Cytoskeletal targets for oncogenic tyrosine kinases. I Cell SCi, 99, 207-21 1 .

Koks, C. A., Dunselman, G. A., de Goeij, A. F., Arends, J. W. and Evers, J. L. (1997) Evaluation of a menstrual cup to collect shed endometrium for in vitro studies. Fertil Steril, 68, 560-564.

Koks, C. A., Groothuis, P. G., Dunselman, G. A., de Goeij, A. F. and Evers, J. L. (1999) Adhesion of shed menstrual tissue in an in-vitro model using amnion and peritoneum: a light and electron microscopic study. Hum Reprod, 14, 816-822.

Koks, C. A., Demir Weusten, A. Y., Groothuis, P. G., Dunselman, G. A., de Goeij, A. F. and Evers, J. L. (2000) Menstruum induces changes in mesothelial cell morphology. Gynecol Obstet invest, 50, 13-18.

Ma, T. Y., Hollander, D., Tran, L. T., Nguyen, D., Hoa, N. and Bhalla, D. (1995) Cytoskeletal regulation of Caco-2 intestinal monolayer paracellular permeability. I Cell Physiol, 164, 533-545.

Mathew, G., Watson, D. I., Rofe, A. M., Ellis, T. and Jamieson, G. G. (1997) Adverse impact of pneumoperitoneum on intraperitoneal implantation and growth of tumour cell suspension in an experimental model. Aust NZ J Surg, G7, 289-292.

Morali, O. G., Delmas, V., Moore, R., Jeanney, C., Thiery, J. P. and Larue, L. (2001) IGF-II induces rapid beta-catenin relocation to the nucleus during epithelium to mesenchyme transition. Oncogene, $20,4942-4950$.

Mutsaers, S. E. (2002) Mesothelial cells: their structure, function and role in serosal repair. Respirology, 7, 171-191.

Nieto, M. A. (2002) The snail superfamily of zinc-finger transcription factors. Nat Rev Mol Cell Biol, 3. 155-166.

Perez-Pomares, J. M. and Munoz-Chapuli, R. (2002) Epithelial-mesenchymal transitions: a mesodermal cell strategy for evolutive innovation in Metazoans. Anat Rec, 268, 343-351.

Piek, E., Moustakas, A., Kurisaki, A., Heldin, C. H. and ten Dijke, P. (1999) TGF- $\beta$ type I receptor/ALK.5 and Smad proteins mediate epithelial to mesenchymal transdifferentiation in NMuMG breast epithelial cells. J Cell Sci, 112, 4557-4568.

Potempa, S. and Ridley, A. J. (1998) Activation of both MAP kinase and phosphatidylinositide 3 -kinase by Ras is required for hepatocyte growth factor/scatter factor-induced adherens junction disassembly. Mol Biol Cell, 9, 2185-2200.

Rampino, T., Cancarini, G., Giegorini, M., Guallini, P., Maggio, M., Ranghino, A., Soccio, G. and Dal Canton, A. (2001) Hepatocyte growth factor/scatter factor released during peritonitis is active on mesothelial cells. Am J Pathol, 159, 1275-1285. 
Reymond, M. A., Schneider, C., Kastl, S., Hohenberger, W. and Kockerling, F. (1998) The pathogenesis of port-site recurrences. I Gastrointest Surg, 2, 406-414.

Sanfilippo, J. S., Wakim, N. G., Schikler, K. N. and Yussman, M. A. (1986) Endometriosis in association with uterine anomaly. Am J Obstet Gynecol, 154, 39-43.

Savagner, P. (2001) Leaving the neighborhood: molecular mechanisms involved during epithelialmesenchymal transition. Bioessays, 23, 912-923.

Strutz, F., Zeisberg, M., Ziyadeh, F. N., Yang, C. Q., Kalluri, R., Muller, G. A. and Neilson, E. G. (2002) Role of basic fibroblast growth factor-2 in epithelial-mesenchymal transformation. Kidney Int, 61 , 1714-1728

Thomas, S. M., Soriano, P. and Imamoto, A. (1995) Specific and redundant roles of Src and Fyn in organizing the cytoskeleton. Noture, 376, 267-271.

Timpson, P., Jones, G. E., Frame, M. C. and Brunton, V. G. (2001) Coordination of cell polarization and migration by the Rho family GTPases requires Src tyrosine kinase activity. Curr Biol, 11, 18361846.

Valles, A. M., Boyer, B., Badet, J., Tucker, G. C., Barritault, D. and Thiery, J. P. (1990) Acidic fibroblast growth factor is a modulator of epithelial plasticity in a rat bladder carcinoma cell line. Proc Notl Acad Sci USA, 87, $1124-1128$.

Vanzetti, G. (1966) An azide-methemoglobin method for hemoglobin determination in blood. J Lab Clin Med, 67, 116-126.

Wang, Y. L. (1991) Dynamics of the cytoskeleton in live cells. Curr Opin Cell Biol, 3, 27-32.

Yanez-Mo, M., Lara-Pezzi, E., Selgas, R., Ramirez-Huesca, M., Dominguez-Jimenez, C., JimenezHeffernan, J. A. Aguilera, A., Sanchez-Tomero, J. A., Bajo, M. A., Alvarez, V, et al. (2003) Peritoneal dialysis and epithelial-to-mesenchymal transition of mesothelial cells. N Engl J Med, 348, 403-413.

Yang, A. H., Chen, J. Y. and Lin, J. K. (2003) Myofibroblastic conversion of mesothelial cells. Kidney Int, 63, 1530-1539.

Zhu, Z., Yao, J., Wang, F. and $X U_{1}$ Q. (2002) TNF- $\alpha$ and the phenotypic transformation of human peritonea! mesothelial cell. Chin Med J, I15, 513-517. 


\title{
[ Chapter 6$]$
}

\section{Proteome analysis of human mesothelial cells during epithelial to mesenchymal transitions induced by shed menstrual effluent}

\author{
A.Y. Demir' \\ G.A.J. Dunselman ${ }^{1.2}$ \\ M. Puype \\ H. Demol ${ }^{3}$ \\ A. Herrler ${ }^{4}$ \\ A.F.P.M. de Goeij ${ }^{1,5}$ \\ J.L.H. Evers \\ J. Vandekerckhove \\ P.G. Groothuis
}

'Research Institute Growth and Development (GROW), Departments of Obstetrics and Gynaecology and 'Pathology, Academic Hospitol and Maastricht University, Moastricht, The Netherlands, "3epartment of Biochemistry, Foculty of Medicine and Health Sciences, Flanders Interuniversity, Institute for Biotechnology, Ghent University, Chent, Belgium, "Department of Anatomy and Reproductive Biology, RWTH, University of Aachen, Aachen, Germany 
Chopter 6 


\section{Abstract}

Peritoneal endometriosis is the result of ectopic implantation and growth of endometrium tissue that has been regurgitated into the abdominal cavity during menstruation. We have previously shown that menstrual effluent induces epithelial to mesenchymal transitions (EMT) in mesothelial cells, which results in cell retraction and exposure of submesothelial extracellular matrix. Since endometrial tissue preferentially adheres to the extracellular matrix, adhesion of endometrial tissue to the peritoneum is facilitated. The EMT were shown to be associated with differential expression and phosphorylation of mesothelial proteins.

Using radiolabeling and proteomics we detected changes in protein expression and phosphorylation that occur in mesothelial cells during the EMT process. The identity of 74 proteins, which were obtained from 324 analysed spots, was confirmed. The expression of 35 proteins involved in organization of the cytoskeleton, signal transduction, regulation of the redox state and production of ATP, was altered during the EMT process. Four of the identified proteins were differentially phosphorylated: annexin- 1 , an actin binding protein and a substrate for receptor tyrosine kinases; tropomyosin- $\alpha$, a regulator of actin filament stability and cell shape; elongation factor 1 delta; ATP synthase $\beta$ chain.

In conclusion, factors from menstrual effluent induce specific changes in the expression and phosphorylation status of structural, regulatory and metabolic proteins relevant to the complex process of EMT in mesothelial cells. 


\section{Introduction}

Endometriosis is the presence of functional endometrial glands and stroma at ectopic locations, most frequently at the peritoneum in the abdominal cavity. It presents with an array of complaints including pelvic pain, dysmenorrhea and subfertility in women of reproductive age. A large body of evidence supports the theory of retrograde transplantation to explain the pathogenesis of endometriosis (Sampson, 1940). This theory indicates that during menstruation viable endometrial tissue is pushed through the oviducts into the abdomen, adheres to the peritoneal surface and progresses towards a functional lesion.

In previous in vitro studies we have shown that endometrial tissue preferentially adheres to submesothelial structures and not to the intact monolayer of mesothelial cells (Groothuis et al., 1998; Koks et al., 1999). In addition, shed menstrual endometrium was clearly shown to induce a process of cell remodeling in mesothelial cells and not of apoptosis or necrosis (Demir Weusten et al., 2000). This process results in the retraction of mesothelial cells and the exposure of extracellular matrix, to which endometrium cells easily adhere and grow (Koks et al., 1999; Demir Weusten et al., 2000; Koks et al., 2000). The changes occurring in the mesothelial cells, include the disruption of cell-cell contacts, the induction of reversible changes from an epithelial-like to a fibroblast-like morphology, and the increase in the motility of cells (Demir et al., 2004), met all the features of epithelial to mesenchymal transitions (EMT). The epithelial to mesenchymal transitions as shown in other cell types result from the activation of signaling cascades, including phosphorylation by tyrosine kinases and/or serine/threonine kinases (Boyer et al, 2000). Protein phosphorylation in the responding cells affects protein conformations and enzyme activities, and alter the expression of genes and proteins (Hay, 1995; Boyer et al., 2000). Src tyrosine kinases have been reported to be regulators of growth factor-induced cell scattering and motility. Besides Src tyrosine kinases, other signaling pathways which comprise intermediates such as Ras, Rac, Rho, mitogen activated protein kinase (MAPK) and phosphatidylinositol-3 kinase $\left(\mathrm{PI}_{3} \mathrm{~K}\right)$ are involved in growth factor- and substrate-induced cell migration, focal adhesion (dis)assembly, formation of stress fibers, membrane protrusions and extensions (Frost et al., 1998; Boyer et al., 2000; Hall and Nobes, 2000; EtienneManneville and Hall, 2002).

Based on these reports and our findings, we hypothesize that shed menstrual effluent induces EMT in mesothelial cells by activating phosphorylation cascades that lead to changes in the expression of proteins involved in cytoskeletal organization and energy metabolism. To test this hypothesis we aimed to identify proteins which were differentially phosphorylated and/or differentially expressed in mesothelial cells after induction of the EMT-process by culturing the cells in media conditioned with cells isolated from shed menstrual effluent. We used radiolabeling, two-dimensional polyacrylamide gel electrophoresis and mass spectrometry to identify the proteins functionally related to EMT in mesothelial cells. 


\section{Materials and Methods}

\section{Tissue}

The use of human tissue in this study was approved by the Medical Ethical Committee of the Academic Hospital Maastricht, and all participitating women signed a written informed consent.

\section{Mesothelial cell isolation and culture}

Isolation of human omental mesothelial cells (HOMEC) and preparation of conditioned media were performed as described in a previous report (Demir Weusten et al., 2000). Briefly, the omental tissue $(n=12)$ was minced and incubated with collagenase $(2 \mathrm{mg} / \mathrm{ml}$, ICN Biochemicals B.V., Zoetermeer, The Netherlands) in routine medium (DMEM/Ham's F-12 supplemented with $10 \%$ fetal calf serum, penicillin $100 \mathrm{lU} / \mathrm{ml}$, streptomycin $100 \mu \mathrm{g} / \mathrm{ml}$ and L-glutamine $2 \mathrm{mM}$, amphotericin $0.25 \mathrm{\mu g} / \mathrm{ml}$, from Gibco Life Technologies, Breda, The Netherlands) for 20 minutes at $37^{\circ} \mathrm{C}$. The non-digested tissue was removed by a $400 \mu \mathrm{m}$ stainless sieve (Sigma-Aldrich Chemie B.V., Zwijndrecht, The Netherlands). Subsequently, the cell suspension was sieved through a $100 \mu \mathrm{m}$ nylon mesh filter (Micronic, Lelystad, The Netherlands) and a 10 um polyamide filter (Stokvis \& Smits, IJmuiden, The Netherlands). The cells retained on both of these filters were resuspended in growth medium (MEM D-valine supplemented with 10\% FCS, growth medium supplement: ITS; insulin, transferrin and selenium, nonessential amino acids, L-glutamin 2. mM, pericillin $100 \mathrm{lU} / \mathrm{ml}$, streptomycin $100 \mu \mathrm{g} / \mathrm{ml}$ and amphotericin $0.25 \mu \mathrm{g} / \mathrm{ml}$ ). Culture media were purchased from SigmaAldrich Chemie B.V., supplements were obtained from Gibco Life Technologies. Remaining contaminating stromal cells were separated from mesothelial cells by differential plating. After 30 minutes incubation at $37^{\circ} \mathrm{C}$, the non-adhering cells were collected and placed in a new flask. Confluent HOMEC cultures from passage two were used in the experiments.

\section{Preparation of conditioned media}

Anterogradely shed menstrual effluent $(n=90)$ was collected by healthy volunteers $(n=10)$ who had no history of endometriosis and had regular ovulatory cycles. The clonors used a menstrual cup (Keeper, The Hague, The Netherlands) for 2-3 hours during the first 3 days of menstruation. After collection, the effluent was centrifuged at $1200 \mathrm{~g}$ for 10 minutes (Koks et al., 1997). The serum was stored and referred to as menstrual serum. The remaining tissue was immediately resuspended in routine medium, layered on HistoPaque 1077 (Sigma-Aldrich Chemie B.V.) and centrifuged at $1200 \mathrm{~g}$ for 30 minutes. Endometrial and inflammatory cells were collected from the interphase, washed and cultured in routine medium (DMEM supplemented with 10\% FCS, L-glutamin 2 mM, peni- 
cillin $100 \mathrm{IU} / \mathrm{ml}$, streptomycin $100 \mu \mathrm{g} / \mathrm{ml}$ and amphotericin $0.25 \mu \mathrm{g} / \mathrm{ml})$ for 24 hours at $37^{\circ} \mathrm{C}$ and $5 \% \mathrm{CO}_{2}$. After culture, the medium was removed and centrifuged at $1500 \mathrm{~g}$ for 10 minutes. This supernatant was referred to as conditioned medium. Media prepared from different individuals were combined $(n=15)$ and this pool was filter sterilized. Conditioned media were stored at $-80^{\circ} \mathrm{C}$ until use.

\section{Induction of morphological alterations in HOMEC}

To induce the EMT in HOMEC, cells were grown in 24-well plates until confluency. Prior to incubation in routine or conditioned media for 24 hours, all cultures were cultured overnight in routine medium.

\section{Radiolabeling}

To facilitate the uptake of radiolabeled phosphate by the cells, DMEM/Ham's F12 media, supplemented with 10\% fetal calf serum in both routine and conditioned media was replaced with phosphate-free RPMI 1640 medium containing 10\% dialyzed fetal calf serum. This procedure included repetitive centrifugation steps with centrifugal filter devices with a cut off value at a molecular weight $3 \mathrm{kD}$. After this procedure the phosphate content in the original routine and conditioned media was reduced by $99 \%$ (low-phosphate medium).

The reduced phosphate concentration in routine medium had no visible detrimental effects on mesothelial cell morphology. The reduced phosphate content in conditioned media did not interfere with the induction of EMT.

In order to estimate the incubation period of radiolabeling leading to a maximal detection of differentially phosphorylated proteins in our experimental conditions, with a minimum of cell and protein damage by the radioactivity, HOMEC were cultured in low-phosphate routine or conditioned media, supplemented with ${ }^{3} \mathrm{PO}_{4}(225 \mu \mathrm{Ci} / \mathrm{ml}$, Hartmann Analytic $\mathrm{CmbH}$, Braunschweig, Cermany) for a period of 5 hours, starting 0, 5, 10, 15 hours after the initiation of culture. Since the differentially phosphorylated proteins were detected already in the second period of 5 hours in these pilot experiments, ${ }^{32} \mathrm{PO}_{4}$ was added 4 hours after initiation of culture in conditioned media. Radiolabeling was performed for 5 hours.

\section{Protein sample preparation}

After incubation, ${ }^{32} \mathrm{PO}_{4}$-containing media were removed and $\mathrm{HOMEC}$ were washed with DMEM five times. The cells were immediately brought in lysis buffer containing $8 \mathrm{M}$ urea, 4\% CHAPS, $40 \mathrm{mM}$ Tris, $65 \mathrm{mM}$ DTT, 0.5\% Pharmalytes (Amersham Pharmacia, Roosendaal, The Netherlands) and protease inhibitor cocktail (Boehringer, Almere, The Netherlands). This lysis buffer [compared to urea / CHAPS / tributyl phosphine (TBP), urea / thiourea / CHAPS / DT, urea / thiourea / CHAPS / sulfobetaines 3-10 / TBP] was 
shown to give the best resolution and the lowest amount of streaking (results not shown).

The lysates were centrifuged at $12000 \mathrm{~g}$ for 30 minutes at $4^{\circ} \mathrm{C}$ and the protein concentrations of supernatants were determined using either a nephelometer or a PlusOne 2-D Quant Kit (Amersham Pharmacia).

\section{D-PAGE}

2D-PAGE was performed by combining isoelectric focusing (IEF) in the first dimension and sodium dodecyl sulfate-polyacrylamide gel electrophoresis (SDS-PAGE) in the second dimension (Görg et al., 2000). First-dimensional electrophoresis was carried out using either a Multiphor II horizontal electrophoresis system supported by an EPS 3500 power supply or an IPGphor apparatus with $18 \mathrm{~cm}$ immobilized pH gradient (IPG) strips ( $\mathrm{pH}$ range 3-10 linear or $\mathrm{pH}$ range 4-7 linear, all Amersham Pharmacia). Equal amounts of sample were applied during 12-16 hours to the IPG strips using in-gel rehydratation method. The rehydratation solution was composed of $8 \mathrm{M}$ urea, $2 \%$ CHAPS, $0.5 \%$ Pharmalytes 3-10 or 4-7, 0.7w DT and protease inhibitor cocktail. A total sample volume of $360 \mu \mathrm{l}$ containing $100 \mu \mathrm{g}$ (analytical gels) and $500 \mu \mathrm{g}$ (micropreparative gels) was loaded per strip. For analytical gels Multiphor II (150V, 300V, 600V, 1000V, each 1 hour and 3500V for 6 hours) and for micropreparative gels IPGphor (200V, 500V, $1000 \mathrm{~V}$ each 1 hour, gradual increase to $8000 \mathrm{~V}$ for another hour, $8000 \mathrm{~V} 12$ hours) was used. The focussed strips were saved at $-70^{\circ} \mathrm{C}$.

Electrophoresis in the second dimension was carried out with either the Multiphor II system or the Ettan Dalt vertical system. The SDS-PACE gels used for Multiphor II were gradient gels ( $12 \% \mathrm{~T}, 2 \% \mathrm{C}-14 \% \mathrm{~T}, 0.5 \% \mathrm{C}$ ) on a plastic packing with a thickness of $0.5 \mathrm{~mm}$ and with a stacking gel $(6 \% \mathrm{~T}, 3 \% \mathrm{C})$. For the Ettan Dalt vertical system $1 \mathrm{~mm}$ thick homogenous gels $(12 \% \mathrm{~T}, 2.6 \% \mathrm{C})$ were used. IPC strips were equilibrated for two times 15 minutes in $6 \mathrm{M}$ urea, 35\% v/v glycerol, 3\% w/v SDS, $50 \mathrm{mM}$ Tris- $\mathrm{HCl}, \mathrm{pH} 8.8,1 \mathrm{mM}$ EDTA, containing $1 \% \mathrm{w} / \mathrm{v}$ DTT and $4 \%$ iodoacetamide for the first and second period of equilibration, respectively. The strips were placed on the horizontal gels and proceeded to an electrophoretic run at $100 \mathrm{~V}$ for 80 minutes followed by $600 \mathrm{~V}$ for 4 hours at $15^{\circ} \mathrm{C}$. In the case of vertical gel runs strips were placed on top and overlayed with $0.5 \%$ agarose and subjected to electrophoresis with $5 \mathrm{~W} / \mathrm{gel}$ for 1 hour followed by $120 \mathrm{~W}$ maximum for 4 hours at $20^{\circ} \mathrm{C}$. For Multiphor 11 electrophoresis ExcelGel SDS Buffer Strips (anode: Tris/Acetate and cathode: Tris/Tricine, Amersham Pharmacia) and for Ettan-Dalt runs Tris-Clycine-SDS (BioRad, Veenendaal, The Netherlands) were used as running buffers.

\section{Spot detection}

After the electrophoretic run, gels were fixed with $40 \%$ ethanol and 10\% acetic acid for 30 minutes. The phosphorylated spots were detected by layering either Kodak Biomax MS film or screens for the phosphoimager onto the gels overnight at $-70^{\circ} \mathrm{C}$ or $4^{\circ} \mathrm{C}$, respective- 
Iy. After developing the X-ray film and scanning the screen, the gels were stained by a silver staining protocol (Heukeshoven and Dernick, 1988). The gels prepared for mass spectrometry analysis were stained either with a modified silver staining protocol (Blum, 1987) or with a fluorescent dye SyproRuby according to the manufacturer's recommendations (BioRad). 2D-PAGE profiles were scanned with a GS-800 densitometer (for silver stained gels) or with a FX-Multimage laser densitometer (for SyproRuby stained gels). The comparative analysis was performed using PD-Quest software (BioRad). The spots of interest in the comparision between routine medium and conditioned media were defined either as differentially phosphorylated $(n=12)$ or as differentially expressed $(n=12)$. These spots were excised from the gels stained with SyproRuby by using a spot picker apparatus (BioRad), pooled and subjected to mass spectrometry analysis of peptide mass fingerprints.

\section{Protein identification by mass spectrometry}

Excised spots were in-gel digested with trypsin. Prior to analysis, peptide samples were concentrated and desalted by the addition of a small amount of Poros $B 50 R 2$ beads (Boehringer Mannheim, Mannheim, Germany) as described previously (Gevaert et al., 1997). These beads were transferred onto the target disc of a Reflex III (Bruker Daltonics, Bremen, Germany) Matrix Assisted Laser Desorption lonization Time of Flight (MALDI-TOF) and the peptides desorbed from the beads by adding $1 \mu l$ of matrix solution. Details of this procedure and on the MALDI-analysis are described in a previous report (Gevaert et al., 1997). Proteins were identified by peptide mass fingerprinting using the NCBI and Swiss Prot sequence databases using the Mascot search algorithm (Cottrell, 1994). For confirmation, we often performed post-source-decay analysis (Gevaert et al., 2001), providing partial sequence information on a few selected peptides.

\section{Results}

The epithelial to mesenchymal transitions which were induced in mesothelial cells by conditioned media prepared from menstrual effluent are illustrated in Figure? . The mesothelia! cells displayed morphological features of epithelial cells during control culture conditions and were dissociated from each other and gained a mesenchymal-like morphology after culture in conditioned media (see for time-lapse video film http://www.grow.unimaas.n// biology_merg_movies.htm).

Figure 1. Mesothelial cell morphology after culture in routine medium or conditioned media prepared from anterogradely shed menstrual effluent for 4, 8, 12, 16 and 20 hours. The cells were incubated in low phosphate medium during the intervals $0-4,4-8,8-12,12-16$ and 16-20 hours. (RM) Routine medium, (CM) Conditioned media. 
$R M$

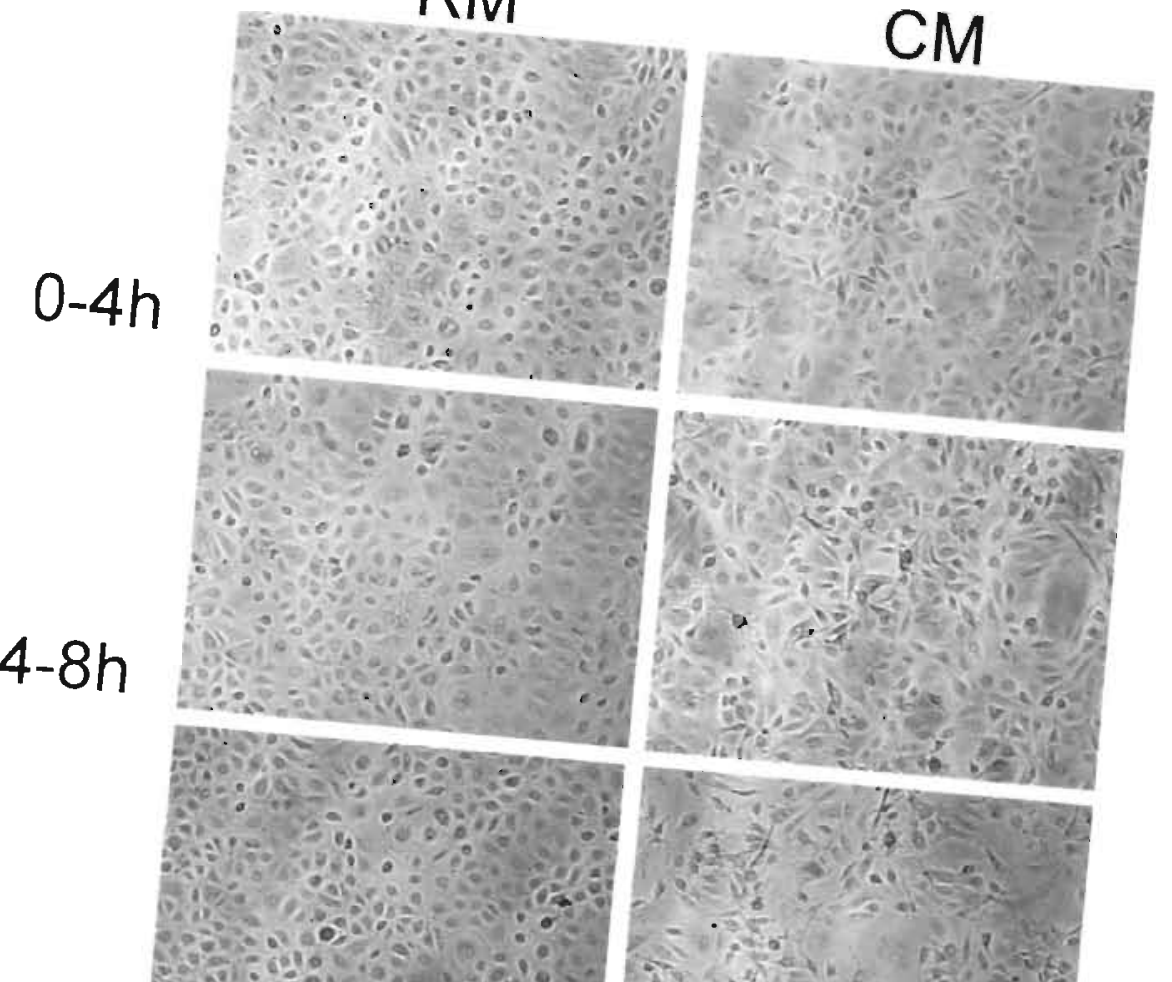

$8-12 \mathrm{~h} \cdots \cdots$

$12-16 h \quad \because \because \because 8$
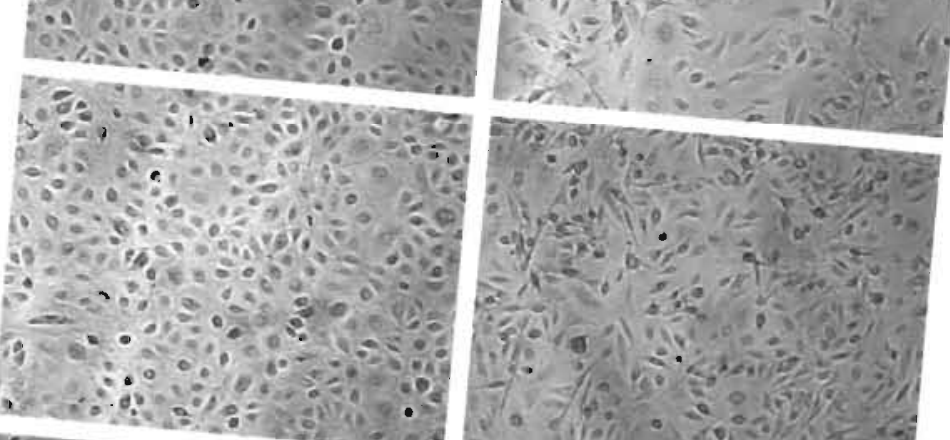

$6-20 h$
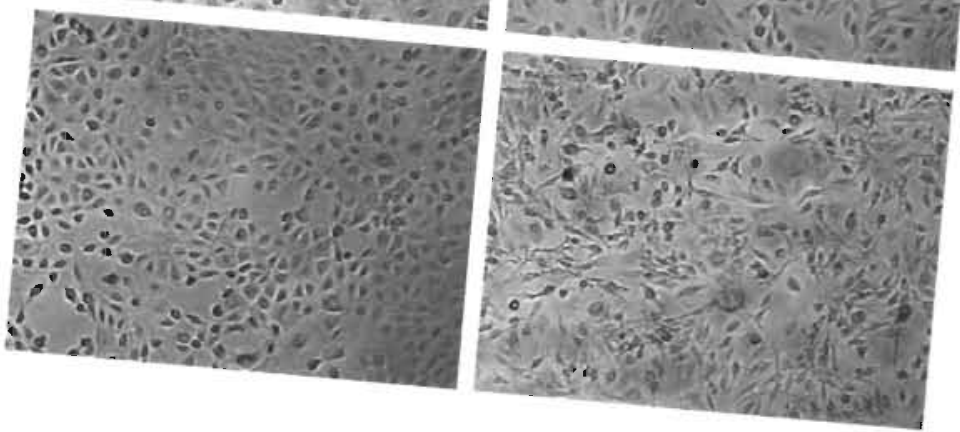
To examine the effect of conditioned media on the differential expression and phosphorylation of proteins during the EMT in mesothelial cells, the proteins obtained after lysing the cells were separated by two-dimensional gel electrophoresis.

From the gels, 324 spots were picked and analysed by mass spectrometry, 74 proteins were identified (Tables 1 and 2). Of these identified protens, 39 did not change their expression during the EMT process in mesothelial cells (Figure 2, Toble 1). The multiple comparisons between protein patterns obtained from cells cultured in routine and conditioned media revealed various proteins that were differentially expressed in mesothelial cells after culture in conditioned media (Figure 3). Proteins expressed at a two-fold lower or higher level are listed in Table 2. The expression of most of the proteins was up-regulated, with the exception of cytokeratins 7 and 19, protein disulfide isomerase precursor and nucleoside diphosphate kinase $A$.

Figure 4 presents the radiograms, showing the differentially phosphorylated proteins, and the silver stained 2D-gels used for the autoradiography. When a wide-range $\mathrm{pH}$ gradient (pH 3-10) was used in the first dimension, two proteins were found phosphorylated as a result of culturing in conditioned media in repetitive experiments. One of these proteins was also newly expressed, but could not be identified. These proteins had a molecular weight of 35-40 kD and a pl range of 4.5-5. To evaluate the proteins in more detail, narrow-range $\mathrm{pH}$ gradients ( $\mathrm{pH} \mathrm{4-7)}$ ) were used for separation of mesothelial proteins in the first dimension (Figure 5). This approach revealed 12 differentially phosphorylated proteins after culturing mesothelial cells in conditioned media. Analysis of these protein spots with mass spectrometry provided identities of four differentially phosphorylated proteins, i.e. annexin-1, tropomyosin- $x$, chain, elongation factor 1-delta and ATP synthase $\beta$ chain (Table 2), whereas the peptide profiles of the other 8 proteins could not be identified with the available databases. One of the phosphorylated proteins was newly expressed and identified as annexin-1.

Table 1: Identities of protein spots in mesothelial cells cultured under control conditions.

\section{Protein identity}

Annexin family

Annexin 3

Annexin A4

Annexin 5

ATP related proteins

Translational endoplasmic reticulum ATPase

Vacuolar ATP synthase subunit $F$

\section{Accession number \\ 2D-gel}

P12429

2.6

P09525 27

P08758 22

P55072

Q16864 
Calcium binding proteins

Calgizzarin

P31949

Calumenin precursor

043852

Calretinin

Nucleobindin 1

P22676

6

Cell surface proteins

Galectin- 1

Cytoskeleton proteins

B-Actin

P09382

6

Cytokeratin 18, type I

P02570

Cytokeratin 23, type I

P05783 16

Myosin light chain alkali, smooth muscle isoform

Q9C075 25

Myosin regulatory light chain 2, nonsarcomeric

P24572 35

P19105

Cytoskeleton and related proteins

Dynactin complex $50 \mathrm{kD}$ subunit

Q13561 $\quad 11$

Profilin

P35080

Enzymes

Aldehyde dehydrogenase $X$, mitochondrial

P30837

Aminoacylase- 1

Q03154

Cathepsin D precursor

P07339

Mitochondrial processing peptidase $\beta$ subunit

075439

$\mathrm{NADH}$-ubiquinone oxidoreductase $75 \mathrm{kD}$ subunit

P28331

6-Phosphogluconolactonase

095336

D-3-phopshoglycerate dehydrogenase

043175

Protein disulfide isomerase $A 3$

P30101

Proteosome subunit $\alpha$-type 5

P28066

Pyruvate dehydrogenase $E 1$ component $\beta$ subunit

Ubiquitin carboxyl-terminal hydrolase isozyme $L 3$

PI5374

Heat shock proteins

$60 \mathrm{kD}$ heat shock protein, mituchondrial

P10809

Stress-70 protein, mitochondrial

P38646

P 11142

Heat shock cognate $71 \mathrm{kD}$ protein

P1 1021

4

$78 \mathrm{kD}$ glucose-regulated protein precursor

Immune system related proteins

HLA class histocompatability antigen, A-31

P16189 24

HLA class histocompatability antigen, B-7

P01889

Regulatory proteins involved in the redox state

Thioredoxin-like protein

Proteins associated with transcription and translation

Endoplasmic reticulum protein ERp29 precursor

Eukaryotic translation initiation factor 3 subunit 
$\mathrm{pH} 4$

$\mathrm{pH} 7$

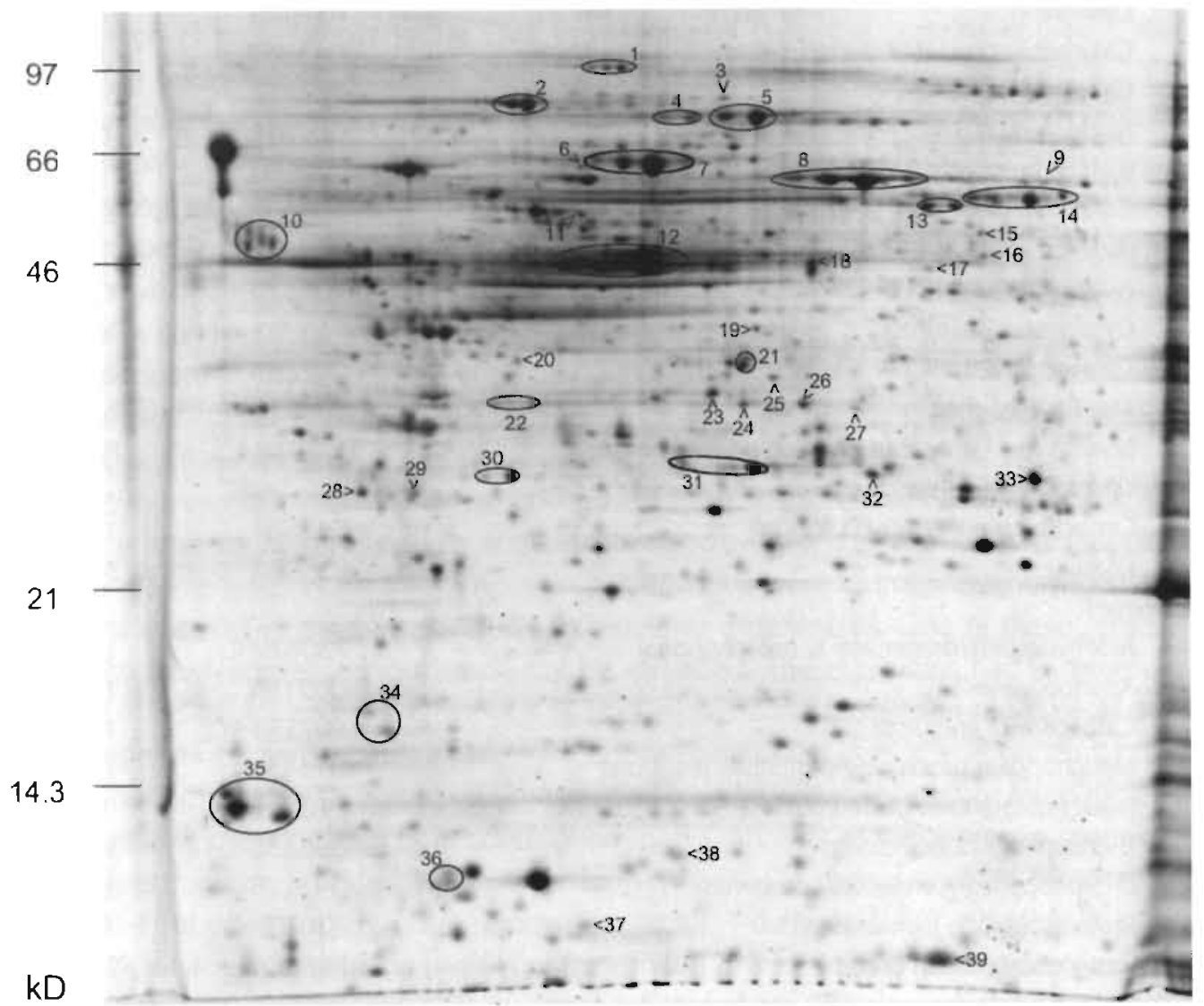

Figure 2. Mesothelial cell proteins separated by two-dimensional gel electropharesis using a narrow range $\mathrm{pH}$ gradient ( $\mathrm{pH}$ 4-7) (see Table I).

Table 2: The identities of the protein spots that were differentially expressed or phosphorylated in mesothelial cells induced by shed menstrual endometrium.

\section{Protein identity}

Differentially phosphorylated proteins

Annexin 1

ATP synthạse $\beta$ chain

Elongation factor 1 delta

Tropomyosin- $\alpha 4$ chain

\section{Expression Accession Number on number 2D-gel}

$\begin{array}{ccc}\text { NE } & \text { P04083 } & 57 \\ \text { HE } & \text { P06576 } & 44 \\ -. & P 29692 & 59 \\ - & \text { P07226 } & 58\end{array}$




\section{Differentially expressed proteins}

Channel proteins

Chloride intracellular channel protein 1

000299

Cytoskeleton proteins

Cytokeratin 7, type 11

P08729

Cytokeratin 8, type 11

P05787

Cytokeratin 19, type I

P08727

50

Tubulin $\beta 1$ chain

Vimentin

P08670

Cytoskeleton related proteins

Caldesmon

Q05682

40

F-actin capping protein $\alpha$-subunit

F-actin capping protein $\beta$-subunit

P47756

Heat shock protein 27

P04792

68

LIM \& SH3 domain protein 1

Q14847

56

Macrophage capping protein

P40121

53

Stathmin (Phosphoprotein 19)

P16949

73

Tubulin specific chaperone A

075347

Enzymes

Adenine phosphoribosyltransferase

HE

P07741

Aldehyde dehydrogenase,

mitochondrial precursor

HE

P05091

46

$\alpha$-Enolase

P06733

Galactokinase

P51570

Nucleoside diphosphate kinase A

P15531

Protein disulfide isomerase precursor

P07237

Proteosome subunit $\alpha$-type 1

Proteins involved in signal transduction

Ran specific GTPase activating protein

HE

P43487

66

Rho GDP dissociation inhibitor 1

HE $\quad P 52565$

Proteins involved in transcription and translation

605 acidic ribosomal protein

HE

P05388

Heterogenous nuclear ribonucleoprotein $\mathrm{K}$

Q07244

Mitochondrial 28 ribosomal protein

P82650

Nuclear protein $\mathrm{Hcc}-1$

P82979

Regulatory proteins involved in the redox state of the cells

Glutathione $S$ transferase P

P09211

67

Peroxidoredoxin 2

$\mathrm{HE}$

P32119

70

Thioredoxin dependent peroxide reductase

HE

P30048

Other proteins

Low affinity IgG epsilon FC receptor

HE

P06734

*: Differential expression ofter EMT. HE: Higher expression, LE: Lower expression, NE: New expression, (-): no change. 

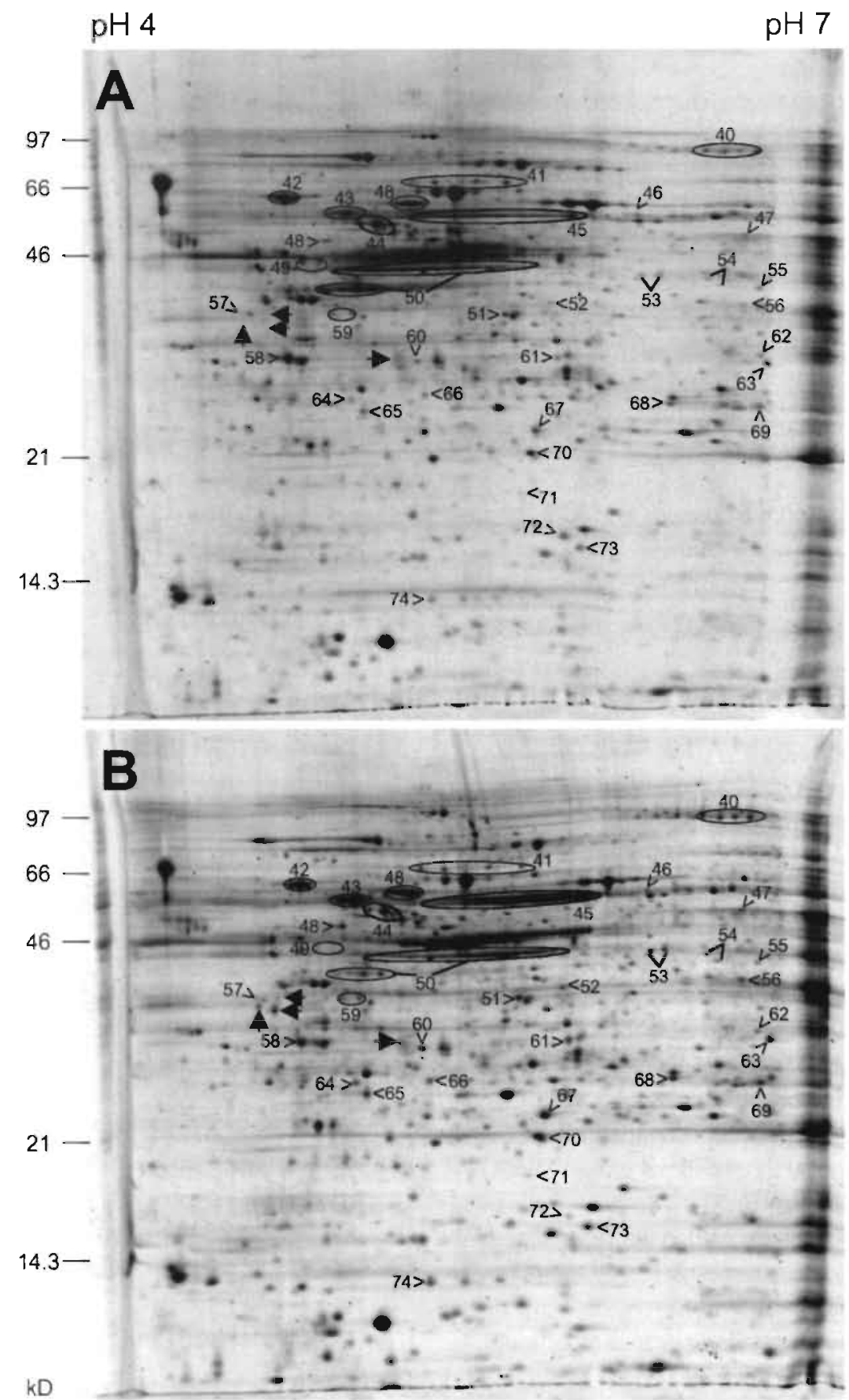

Figure 3. The patterns of mesothelial cell proteins separated by two-dimensional gel' electrophoresis using a narrow range $\mathrm{pH}$ gradient ( $\mathrm{pH}$ 4-7). (A) Routine medium, (B) Conditioned media. The gels were stained with SyproRuby. The identified differentially expressed proteins (see Table 2) are marked on the gel. The newly expressed proteins: are indicated in dark-arrows. 

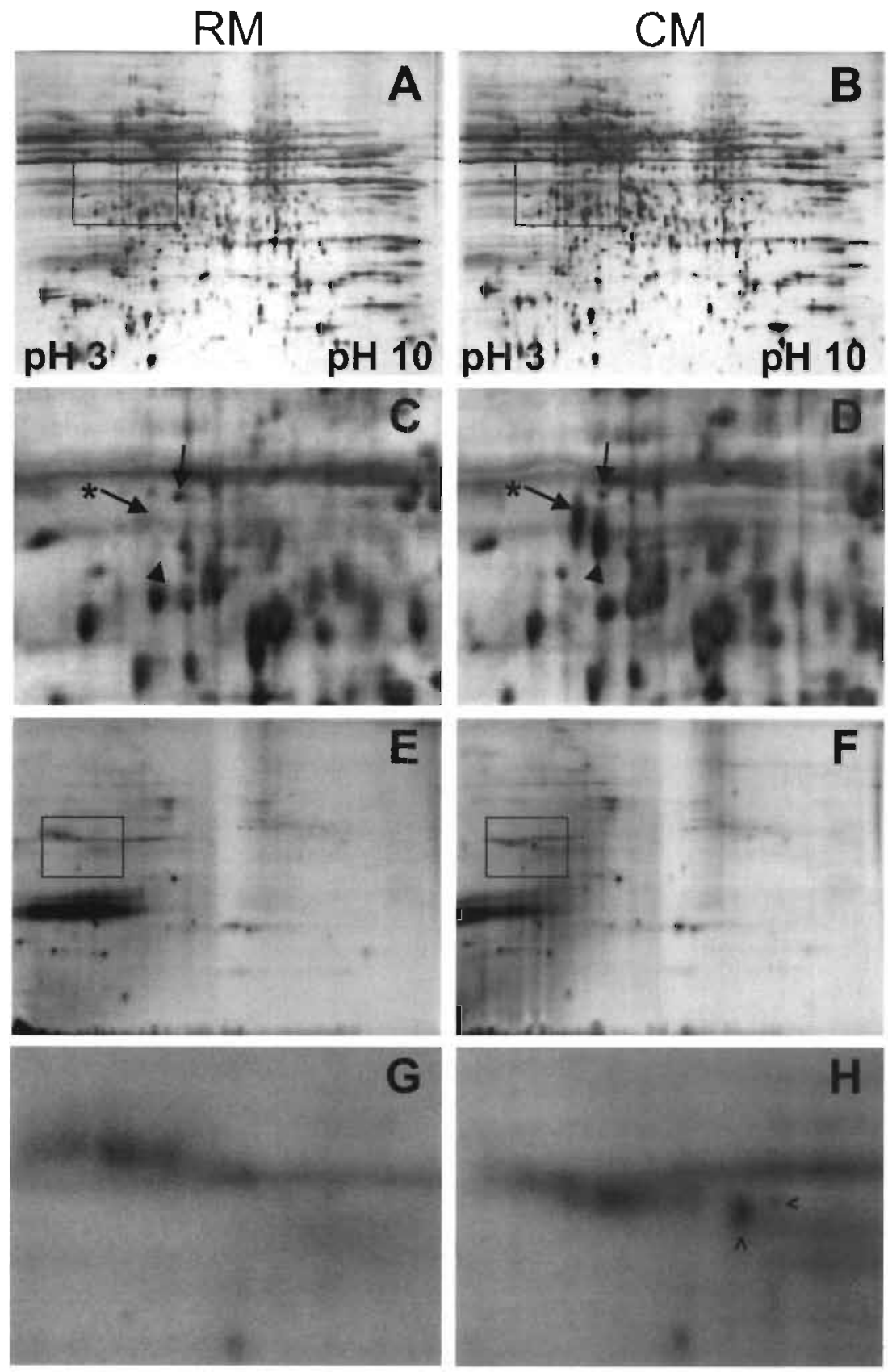

Figure 4. Mesothelial cell proteins separated by two-dimensional electrophoresis using a wide range $\mathrm{pH}$ gradient ( $\mathrm{PH}$ 3-10). (A - D) Silver staining. (E-H) Rodiograms. The indicated areas on panels A\&B and E\&F ore enlorged in panels C\&D and G\&H, respectively. The differentially phoshorylated proteins and their corresponding position on the gels are indicated by arrows. The protein indicated with * was newly expressed. The proteins up-regulated during EMT are indicated by arrow-heads. (RM) Routine medium, (CM) Conditioned media. 

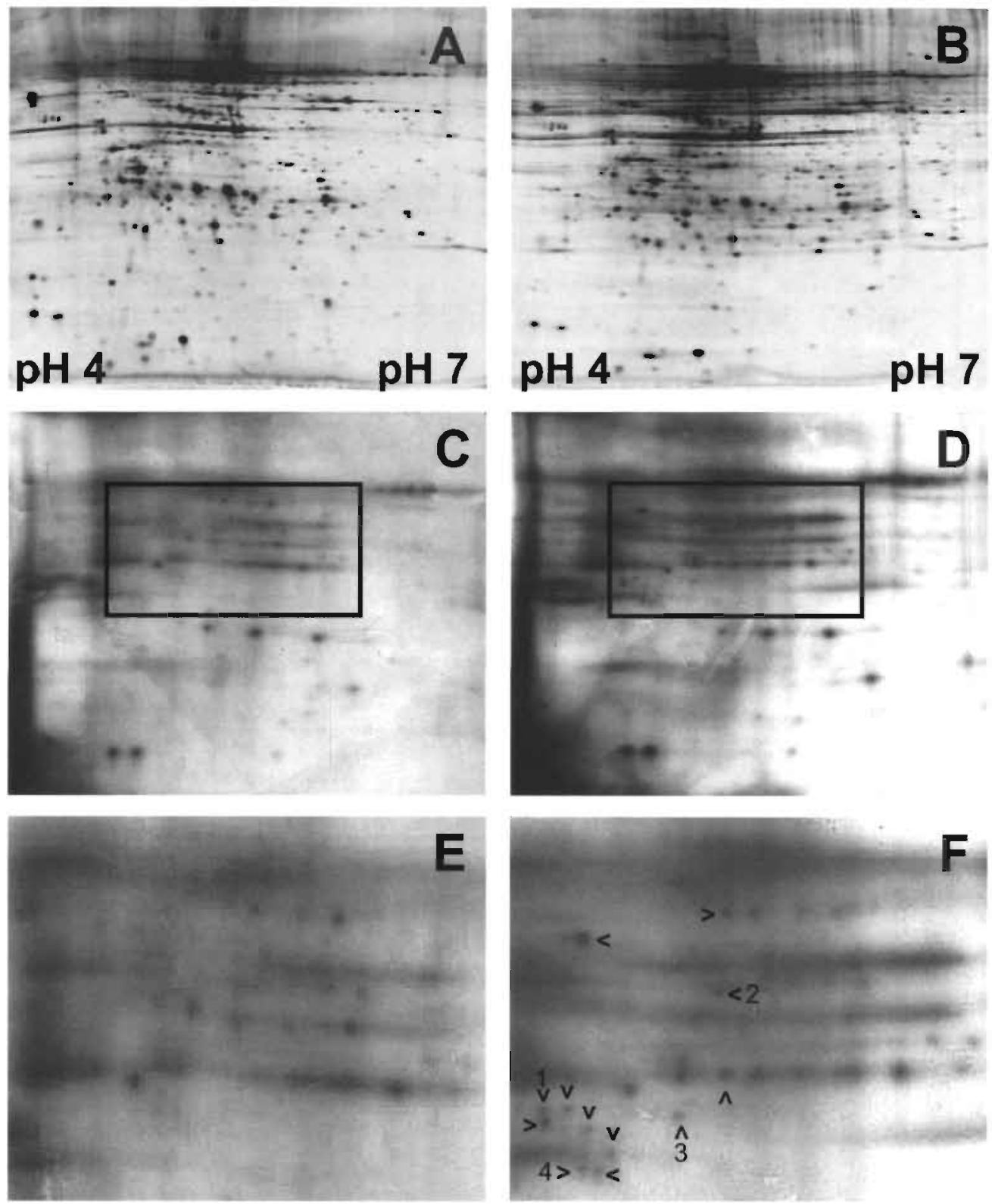

Figure 5. Mesothelial cell proteins separated by two dimensional electrophoresis using a narrow range $\mathrm{pH}$ gradient ( $\mathrm{PH} 4$-7). The gels were stained with silver (A\&B) and exposed to a $X$-ray film (C-F). The indicated areas on pane/s C\&D are enlarged in panels E\&F. The differentially phoshorylated spots are indicated by arrow-heads. The phosphorylated spots that could be identified are marked with numbers: (1) annexin-1, (2) ATP synthase $\beta$-chain, (3) elongation factor 1 delto, (4) tropomyosin- $\alpha 4$. 


\section{Discussion}

Epithelial to mesenchymal transitions (EMT) in mesothelial cells induced by shed menstrual effluent are energy dependent and mediated by tyrosine kinase signaling (Demir et al., 2004). This process has been shown to affect the phosphorylation status and expression of proteins that are directly or indirectly involved in organization of the cytoskeleton, signal transduction, redox state of the cell, production of ATP, regulation of metabolic activity and gene transcription.

Two-dimensional polyacrylamide gel electrophoresis (2D-PAGE) was used to identify proteins that were differentially phosphorylated and/or differentially expressed during the EMT process. From the 324 spots analysed, 74 identity matches were found in the peptide map database searches. This can be explained by the fact that we picked various adjacent spots that were likely post-translationally modified isoforms. In addition, some spots were found to be breakdown products of other highly abundant proteins. Of these 74 proteins, the expression and phosphorylation of 35 proteins was affected during EMT.

Many of these proteins are directly or indirectly associated with cytoskeletal restructuring during the EMT process. Using broad pH gradients (3-10) two proteins were detected that were phosphorylated during EMT. One of the two proteins was newly expressed in the mesothelial cells after EMT. However, the use of a more narrow-range pH gradient (4-7) in the first dimension revealed 10 other newly phosphorylated proteins in mesothelial cells during the EMT process. From these 10 additional phosphorylated proteins, four could be identified. The rest remained unknown, mainly due to the very limited amount of protein that could be recovered from the gels.

Two differentially phosphorylated proteins were identified as annexin-1 and tropomyosin- $\alpha_{4}$. Both proteins are involved in the organization of the actin filaments. Annexin- 7 is an actin binding protein which plays a role in signal transduction to the cytoskeleton and membranecytoskeleton organization (Alvarez-Martinez et al., 1997; Pencil and Toth, 1998). Another phosphorylated protein was elongation factor 1 delta which is involved in cytoskeletal organization, signal transduction, translational control and oncogenic transformation (Ejiri, 2002).

Tropomyosin in non-muscle cells may be required for regulating actin filament stability, cell shape determination and cytokinesis (Lin et al., 1997). To exert its effect tropomyosin acts in concert with other actin-binding proteins, some of which were also increased in the mesothelial cells during EMT. For instance, caldesmon, which is a member of the troponin-C family of calcium-binding proteins, is implicated in actomyosin interactions and in stimulation of binding of tropomyosin to actin in non-muscle cells (Pollock and Santiesteban, 1995; Lin et al., 1997). Fibrillar actin capping protein subunits $\alpha$ and $\beta$ bind to the growing ends of actin filaments, which is a critical step for regulating actin-based motility in nonmuscle cells. Macrophage capping protein binds to actin monomers and nucleates actin assembly (Young et al., 1994). LIM \& SH3 domain protein 1 (Laps-1) binds to non-muscle filamentous actin in vitro in a phosphorylation-dependent manner (Chew et al., 2002). 
Heat shock protein 27 probably regulates the actin cytoskeleton structure and modulates the interaction of actin and myosin (Ibitayo et al., 1999). These results show that the EMT induced by menstrual effluent involves rearrangement of the actin cytoskeleton, resulting in dramatic changes in mesothelial cell shape and high cell motility. The down-regulation of the protein disulfide isomerase precuisor supports this contention, since this enzyme was shown to participate in actin filament polymerization (Noiva, 1999).

Next to changes in the expression of proteins associated with the actin cytoskeleton, changes were also observed in the expression of intermediate filaments and microtubules. The expression of cytokeratins 7 and 19 decreased, whereas the expressions of vimentin, cytokeratin 8 and $\beta 1$-tubulin increased. Stathmin, which destabilizes microtubules, and tubulin-specific chaperon A, which is required for tubulin folding (Dobrzynski et al., 1996; Daub et al., 2001), were also increased during the EMT-process in mesothelial cells. These results indicate that a shift in the filament system from cytokeratin to vimentin and a reorganization of the microtubule system are associated with EVIT in mesothelial cells as an effect of shed menstrual effluent.

Another class of proteins up-regulated during EMT is involved in signal transduction. Annexin $\mathrm{l}$ is also a major substrate for the tyrosine kinase activity of receptors for vasoactive peptides and growth factors, i.e. epidermal growth factor, platelet derived growth factor, insulin and hepatocyte growth factor/scatter factor (Campos-Gonzalez et ol., 1990; Salles et al., 1996; Skouteris and Schroder, 1996; Rothhut, 1997; Croxtall et al., 2000; de Coupade et al., 2000). We presume that annexin- 1 modulates upstream components of (Src) tyrosine kinase pathway after activation by soluble factors in menstrual effluent. This is based on literature reports (Rothhut, 1997; Alldridge et al., 1999; Yoshii et al., 2000) and our previous findings which demonstrate that (Src) tyrosine kinases are involved in the epithelial to mesenchymal transitions in mesothelial cells, and that actin filaments are redistributed during this process (Demir et al., 2004).

The elevated expression of Rho-GDP dissociation inhibitor 1 and Ran-specific GTPase activating protein, indicate that next to the Src tyrosine kinase family, the Rho family of small G proteins may form a link between the menstrual factor signal and the cytoskeletal reorganization in mesothelial cells. The Rho-GDP dissociation inhibitor 1 (Rho GDI) regulates the GDP/GTP exchange reaction of the Rho proteins by inhibiting the dissociation of GDP and the subsequent binding of GTP to this complex. The regulation of RhoGDI involves the ezrin/radixin/moesin (ERM)-CD44. system. The interaction of RhoGDI with the ERM-CD44 system results in activation of Rho $A$ and reorganization of actin filaments. Overexpression of these proteins has been associated with tumour cell invasion and survival (Takahashi et al., 1997). During the myofibroblast conversion of mesothelial cells cultured with TGF-Pl the expression of this protein is also altered (Yang et al., 2003). The Ran-specific GTPase activating protein, which regulates the binding and hydrolysis of GTP by Ras-related proteins was also highly expressed (Bischoff et al., 1995). This protein is involved in nuclear transport, mitotic spindle assembly and nuclear envelope assembly 
(Quimby and Dasso, 2003). On the other hand, the down-regulation of nucleoside diphosphate kinase A may enhance the menstrual signal by activating oncogenic Ras proteins, which results in cell motility and differentiation (Aguado-Velasco et al, 1996; Fischbach and Settleman, 2003). These observations support a role for the Src tyrosine kinase family and the Rho family of small $G$ proteins in mediating the signaling between the menstrual factor and cytoskeletal reorganization during EMT in mesothelial cells.

The overexpression of proteins involved in the redox-regulation of the mesothelial cells, i.e. thioredoxin-dependent peroxide reductase, glutathione $S$ transferase and peroxiredoxin-2. indicates that menstrual effluent leads to several changes in the oxidative state of mesothelial cells during the EMT-process. The fact that some of these proteins, i.e. peroxiredoxin-2, participitate in the signaling cascades of growth factors and TNF- $\alpha$ (Rabilloud et al., 2002), make them possible candidates as initiators of the EMT-signal.

The EMT induced by shed menstrual effluent was shown to be dependent on the production of ATP (Demir et al., 2004). This is supported by the observed increase in the expression of proteins involved in this process such as $\alpha$-enolase, adenine phosphoribosyltransferase and ATP synthase $\beta$-chain, which was also newly phosphorylated. In addition, the high increased expression of proteins that are involved in transcriptional or translational control of cell growth, metabolism and carcinogenesis (Choong et al., 2001), such as galactokinase, $60 \mathrm{~S}$ acidic ribosomal protein, heterogenous nuclear ribonudeoprotein $\mathrm{K}$, mitochondrial 28 sibosomal protein and nuclear protein $\mathrm{Hcc}$ - , implies that menstrual effluent up-regulates the metabolic state in mesothelial cells during the ENT process.

The proteins visualized by 2D-PAGE in this study, however, are only a fraction of the proteome of the mesothelial cells. Predominantly the structural proteins are visualized, whereas the majority of important regulatory and signaling molecules are not detected. To complete the proteome of the mesothelium, additional approaches directed towards increasing the sensitivity, identification of hydrophobic proteins as well as high molecular weight proteins must be developed.

The identification of proteins specifically expressed in mesothelial cells may also be of value for the pathologist. It may aid in distinguishing the normal mesothelial cells from other cell types in peritoneal or ascites fluids. Interesting candidates in this respect may be the cytokeratin 23 type I, which is a novel acidic keratin that is highly induced by histone deacetylase inhibitors during differentiation of pancreatic cancer cells (Zhang et al., 2001), and the HLA antigens.

In conclusion, we have shown that various proteins directly and indirectly as sociated with cytoskeleton, signal transduction, redox state of the cell and pioduction of ATP are differentially phosphorylated and expressed during EMT induced in mesothelial cells by shed menstrual effluent. The remodeling of actin filaments is most likely the central event in the changes in mesothelial cell shape and motility during EMT: Any menstrual factor that stimulates (src) tyrosine kinase and/or ras signaling pathways is a potential candidate for the initiation of EMT process in mesothelial cells. A pathophysiological consequence of EMT in 
mesothelial cells may be that chronic stimuli provided by retrogradely shed menstrual endometrium affect the cytoskeletal dynamics of mesothelial cells and may create adhesion sites for endometrial tissue. This mechanism may explain the clinical observation that endometriosis develops with a prolonged or increased exposure of the peritoneum to the retrogradely shed menstrual effluent (Sanfilippo et al., 1986; Darrow et al., 1993; D'Hooghe et al., 1994; Eskenazi and Warner, 1997).

\section{Acknowledgements}

The authors like to acknowledge Dr. Ulrike Schmitz and Mrs. Sabine Eisner (Anatomy Institute, RWTH, Aachen, Germany) for their expert technical support in performing 2DPAGE; Dr. Katrin de Graaf (Department of Pharmacology, RWTH, Aachen, Germany) for her assitance in producing phosphoimages; ing. G.C. de Veen and ing. Natasja Kisters (Department of Pathology) for their technical support in the preparation of conditioned media; Mr. Freek Bouwman (Department of Human Biology, Maastricht Proteomics Center, Maastricht University) for his kind help with mass spectrometry analysis. Further, the technology for protein identification was supported by a part of the grant of Interuniversity Attraction Poles (IUAP) of Belgium given to Prof. Dr. J. Vandekerckhove.

\section{References}

Aguado-Velasco, C., Veron, M., Rambow, J. A. and Kuczmarski, E. R. (1996) NDP kinase can modulate contraction of Dictyostelium cytoskeletons. Cell Matil Cytoskeleton, 34, 194-205.

Alldridge, L. C., Harris, H. J., Plevin, R., Hannon, R. and Byant, C. E. (1999) The annexin protein lipocortin 1 regulates the MAPK/ERK pathway. J Biol Chem, 274, 37620-37628.

Alvarez-Martinez, M. T., Porte, F., Liautard, J. P. and Sri Widada, J. (1997) Effects of profilin-annexin I association on some properties of both profilin and annexin I: modification of the inhibitory activity of profilin on actin polymerization and inhibition of the self-association of annexin I and its interactions with liposomes. Biochim Biophys Acta, 1339, $331=340$.

Bischoff, F. R., Krebber, H., Sminova, E., Dong. W. and Ponstingl, H. (1995) Co-activation of RanGTPase and inhibition of GTP dissociation by Ran- GTP binding protein RanBP1. Embo J, 14, 705-7i5.

Blum, H., Beier H., Gross, H. J.(1987) Improved silver staining of plant proteins, RNA and DNA in polyacrylamide gels. Electrophoresis, 8, 93-99.

Boyer, B., Valles, A. M. and Edme, N. (2000) Induction and regulation of epithelial-mesenchymal transitions. Biochem Phormocol, 60, 1091-1099.

Campos-Gonzalez, R., Kanemitsu, M. and Boynton, A. L. (1990) Epidermal growth factor induces the accumulation of calpactin II on the cell surface during membrane ruffling. Cell Motil Cytoskeleton, $15,34-40$.

Chew, C. S., Chen, X., Parente, J. A., Jr., Tarrer, S., Okamoto, C. and Qin, H. Y. (2002) Lasp-1 binds to non-muscle $\mathrm{F}$-actin in vitro and is localized within multiple sites of dynamic actin assembly in vivo. I Cell Sci, 115, 4787-4799. 
Choong, M. L. Tan, L. K, Lo, S. L. Ren, E. C. Ou, K. Ong S. E. Liang, R. C, Seow, T. K. and Chung M. C. (2001) An integrated approach in the discovery and characterization of a novel nutear protein over-expressed in huer and pancreatic tumours. FEBS Lett, 496, 109-116.

Cotrell, J. S. (1994) Protein identification by peptide mass fingerprinting. Pept Res, 7, 115-124.

Goxtall, 3. D. Choudhury, Q. and Flower, R. \&. (2000) Gheocorticoids act within minutes to inhibst. recrutment of signaling factors to actwated EGF receptors through a receptor-dependent, uariscriptimindependent mechanism. Bi J Phormocol, 130, $289-298$.

Darrow, S. L. Vena, 1. E., Bat, R. E, Zielezny, M. A. Michalek, A. M. and Selman, S. (1993) Menstrual oycle characteristics and the risk of endometriosis. Epidemiology: 4, 135 142.

Daub, H. Gevaert, K., Vandekerckhove, 1, Sobel, A. and Hall, A. (2001) Rac/Cdc42 and p65PAK regulate the microtubule-destabilizing protem stathmin through phosphorylation at serine 16 . joid Chem, 276, $1677-1680$.

de Coupode, C. Gllet, R. Bemoun, M. Biand, P. Russo-Marie, F. and Solito, E. (2000) Annexin i expression and phosphoryation are up-regulated dumg liver regeneration and transfomation in antithrombin III SV40 T large antigen transgenic mice. Hepotology, 31, 371-380.

Demir, A. Y. Groothuis, P. G., Nap, A. W., Punyadeera, C, de Goel, A. F, Evers, 1. L. H. and Durselman, G. A. (2004) Menstrual effluent induces epithelial-mesenchymal transitions in mesothelial cells. Hum Reprod, 19,21-29.

Demir Weusten, A. Y., Groothuis, P. G., Dunselman, G. A., de Goeij, A. F., Arends, J. W. and Fvers, J. L. (2000) Morphological changes in mesothelial cells induced by shed menstrual endometrium in vitro are not primarily due to apoptosis or necrosis. Hum Reprod. 15, 1462-1468.

D'Hooghe, T. M., Bambra, C. S., Suleman, M. A., Dunselman, G. A., Evers, H. L. and Koninckx, P. R. (1994) Development of a model of retrograde menstruation in baboons (Papio anubis). Fertil Steril, 62, 635-638.

Dobrzynski, J. K., Sternlicht, M. L., Farr, G. W. and Sternlicht, H. (1996) Newly-synthesized B-tubulin demonstrates domain-specific interactions with the cytosolic chaperonin. Biochemistry, 35 , $15870-15882$.

Ejiri, S. (2002) Moonlighting functions of polypeptide elongation factor 1: from actin bundling to zinc finger protein R1-associated nuclear localization. Biosci Biotechnol Biochem, 66, 1-21.

Eskenazi, B. and Warner, M. L. (1997) Epidemiology of endometriosis. Obstet Gynecol Clin North Am, 24, 235-258.

Etienne-Manneville, S. and Hall, A. (2002) Rho GTPases in cell biology. Nature, 420, 629-635.

Fischbach, M. A. and Settleman, J. (2003) Specific biochemical inactivation of oncogenic Ras proteins by nucleoside diphosphate kinase. Cancer Res, 63, 4089-4094.

Frost, J. A., Khokhlatchev, A., Stippec, S., White, M. A. and Cobb, M. H. (1998) Differential effects of PAK 1 -activating mutations reveal activity- dependent and-independent effects on cytoskeletal regulation. J Biol Chem, 273, 28191-28198.

Gevaert, K., Demol, H., Puype, M., Broekaert, D., De Boeck, S. Houthaeve, T. and Vandekerckhove, J. (1997) Peptides adsorbed on reverse-phase chromatographic beads as targets for femtomole sequencing by post-source decay matrix assisted laser desorption ionization-reflectron time of flight mass spectrometry (MALDI-RETOF-MS). Electrophoresis, 18:2950-60, 2950-2960.

Gevaert, K., Demol, H., Martens, L., Hoorelbeke, B., Puype, M., Goethals, M., Van Damme, J., De Boeck, S. and Vandekerckhove, J. (2001) Protein identification based on matrix assisted laser desorption/ionization-post source decay-mass spectrometry. Electrophoresis, 22, 1645-1651.

Görg, A., Obermaier, C., Boguth, G., Harder, A., Scheibe, B., Wildgruber, R. and Weiss, W. (2000) The current state of two-dimensional electrophoresis with immobilized $\mathrm{pH}$ gradients. Electrophoresis, 21, 1037-1053.

Groothuis, P. G., Koks, C. A., de Goeij, A. F., Dunselman, G. A., Arends, J. W. and Evers, J. L. (1998) Adhesion of human endometrial fragments to peritoneum in vitro. Fertil Steril, 71, 1119-1124. 
Hall, A. and Nobes, C. D. (2000) Rho GTPases: molecular switches that control the organization and dynamics of the actin cytoskeleton. Philos Trans R Soc Lond B Biol Sci, 355, 965-970.

Hay, E. D. (1995) An overview of epithelio-mesenchymal transformation. Acto Anat, 154, 8-20.

Heukeshoven, J. and Dernick, R. (1988) Improved silver staining procedure for fast staining in PhastSystem Development. Unit. I. Staining of sodium dodecyl suliate gels. Electrophoresis, 9, 28-32.

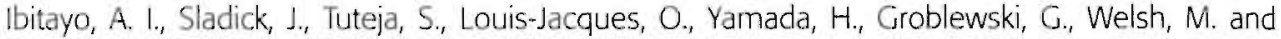
Bitar, K. N. (1999) HSP27 in signal transduction and association with contractile proteins in smooth muscle cells. Am J Physiol, 277, G445-454.

Koks, C. A., Dunselman, G. A., de Goeij, A. F., Arends, J. W. and Evers, J. L. (1997) Evaluation of a menstrual cup to collect shed endometrium for in vitro studies. Fertil Steril, 68, 560-564.

Koks, C. A., Groothuis, P. G., Dunselman, G. A., de Goeij, A. F. and Evers, J. L. (1999) Adhesion of shed menstrual tissue in an in vitro model using amnion and peritoneum: a light and electron microscopic study. Hum Reprod, 14, 816-822.

Koks, C. A., Demir Weusten, A. Y., Groothuis, P. G., Dunselman, G. A., de Goeij, A. F. and Evers, J. L. (2000) Menstruum induces changes in mesothelial cell morphology. Gynecol Obstet Invest, 50, 13-18.

Lin, J. J., Warren, K. S., Wamboldt, D. D., Wang, T. and Lin, J. L. (1997) Tropomyosin isoforms in nonmuscle cells. Int Rev Cytol, 170, 1-38.

Mutsaers, S. E. (2002) Mesothelial ceils: their structure, function and role in serosal repair. Respirology, 7, 171-191.

Noiva, R. (1999) Protein disulfide isomerase: the multifunctional redox chaperone of the endoplasmic reticulum. Semin Cell Dev Biol, 10, 481-493.

Pencil, S. D. and Toth, M. (1998) Elevated levels of annexin I protein in vitro and in vivo in rat and human mammary adenocarcinoma. Clin Exp Metostosis, 16, 113-121.

Pollock, A. S. and Santiesteban, H. L. (1995) Calbindin expression in renal tubular epithelial cells. Altered sodium phosphate co-transport in association with cytoskeletal rearrangement. I Biol Chem, $270,16291-16301$.

Quimby, B. B. and Dasso, M. (2003) The small GTPase Ran: interpreting the signs. Curr Opin Cell Biol, 15, 338-344.

Rabilloud, T., Heller, M.t Gasnier, F., Luche, S., Rey, C., Aebersold, R., Benahmed, M., Louisot, P. and Lunardi, J. (2002) Proteomics analysis of cellular response to oxidative stress. Evidence for in vivo overoxidation of peroxiredoxins at their active site. J Biol Chem, 277, 19396-19401.

Rothhut, B. (1997) Participation of annexins in protein phosphorylation. Cell Mol Life Sci, 53, 522526.

Salles, J. P., Netelenbos, I. C. and Slootweg, M. C. (1996) Growth hormone induces tyrosine phosphorylation of annexin I in rat osteosarcoma cells. Endocrinology, 137, 4358-4362.

Sampson, J. (1940) The development of the implantation theory for the origin of peritoneal endometriosis. Am J Obstet Gynecol, 40, 549-557.

Sanfilippo, J. S. Wakim, N. G., Schikler, K. N. and Yussman, M. A. (1986) Endometriosis in association with uterine anomaly. Am J Obstet Gynecol, 154, 39-43.

Skouteris, G. G. and Schroder, C. H. (1996) The hepatocyte growth factor receptor kinase-mediated phosphorylation of lipocortin-1 transduces the proliferating signal of the hepatocyte growth factor. J Biol Chem, 27!, 272.66-27273.

Takahashi, K., Sasaki, T., Mammoto, A., Takaishi, K., Kameyama, T., Tsukita, S. and Takai, Y. (1997) Direct interaction of the Rho GDP dissociation inhibitor with ezrin/radixin/moesin initiates the activation of the Rho small G protein. I Biol Chem, 272, 23371-23375.

Yang, A. H., Chen, J. Y. and Lin, J. K. (2003) Myofibroblastic conversion of mesothelial cells. Kidney Int, 63, 1530-1539.

Yoshii, K., Sugimoto, K., Tai, Y., Konishi, R. and Tokuda, M. (2000) Purification, identification and phosphorylation of annexin I from rat liver mitochondria. Acto Med Okayama, 54, 57-65. 
Young, C. L., Feierstein, A. and Southwick, F. S. (1994) Calcium regulation of actin filament capping and monomer binding by macrophage capping protein. J Biol Chem, 269, 13997-14002.

Zhang, J. S., Wang, L., Huang, H., Nelson, M. and Smith, D. I. (2001) Keratin 23 (K23), a novel acidic keratin, is highly induced by histone deacetylase inhibitors during differentiation of pancreatic cancer cells. Cenes Chromosomes Cancer, 30, 123-135. 


\section{Chapter 7}

\section{Molecular characterization of}

\section{soluble factors from human menstrual \\ effluent that induce epithelial to \\ mesenchymal transitions in \\ mesothelial cells}

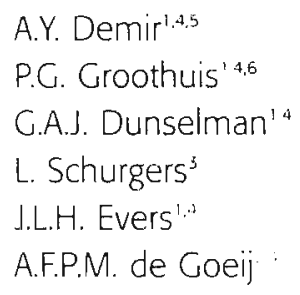

Departments of Obstetrics and Cynaecology', Pathology', and Biochemistry'; Research Institute Growth and Development (GROW); Acodemic Hospital Moostricht and Maostricht University, P.O. Box 5800, 6202 AZ Maostricht, The Netherlands 
Chapter 6 


\section{Abstract}

Soluble factors in menstrual effluent induce epithelial to mesenchymal transitions (EMT) in mesothelial cells. Potentially a large variety of molecules, such as nitric oxide and its reaction products, proteases (i.e. matrix metalloproteinases), and proteins and/or peptides (i.e. growth factors, cytokines) may be involved in this process. Aim of this study is to elucidate the molecular features of these factors.

Using RT-PCR it was demonstrated that all conditioned media prepared from cultured anterogradely shed menstrual effluent induced EMT, but only a few stimulatec iNOS gene expression in mesothelial cells. Using immunofluorescence and Western blotting the patterns of the nitrated proteins were shown to be similar in mesothelial cells cultured either in conditioned media or in control media. Inhibition of matrix metalloproteinase activity did not prevent ENi:.

Biochemical analysis revealed that the inducing factor(s) are heat-labile molecules, are uncharged at neutral $\mathrm{pH}$, have a molecular weight larger than $50 \mathrm{kD}$ or are bound in complexes of that size. Size fractionation demonstrated the albumin fraction (60-70 kD) to contain the responsible factor(s). Two-dimensional gel electrophoresis revealed eleven proteins that were specifically present in conditioned media but not in control medium. Three of these proteins were identified by mass spectrometry as $\alpha$-enolase, haemoglobin $\alpha$ and haemoglobin- $\beta$, respectively.

The induction of EMT by menstrual effluent is caused by proteins with a molecular weight in the range of $60-70 \mathrm{kD}$. Nitric oxide and its reaction products, and matrix metalloproteinases are not responsible for the observed EMT in mesothelial cells. The involvement of $\alpha$-enolase and haemoglobin in this process has to be further evaluated. 


\section{Introduction}

Endometriosis is characterized by the presence of functional endometrium tissue, consisting of epithelial glands and stroma outside the uterine cavity. Although the exact pathogenesis remains unclear, there is increasing evidence for the assumption that retrogradely shed endometrial tissue adheres to the peritoneum and develops into endometriotic lesions. However, the peritoneum forms a protective barrier by its lining of a continuous monolayer of mesothelial cells (dizerega, 1997).

In previous studies we have considered the hypothesis that a damaged mesothelial lining facilitates the adhesion of endometrium, which might lead to development of endometriotic lesions. This is supported by the observation that shed menstrual endometrium preferably adheres to exposed submesothelial structures, rather than to the intact monolayer of mesothelial cells (Koks et al., 1999).

Experimental evidence was obtained that soluble components from menstrual effluent affect mesothelial cells in culture, which leads to morphological alterations and exposure of the underlying basement membrane and extracellular matrix (Koks et al., 2000a). The morphological changes in mesothelial cells include interruption of cell-cell contacts, formation of spindle-like extensions and altered distribution of cytoskeletal proteins (Demir Weusten et al., 2000; Koks et al., 2000a). We also showed that these alterations in mesothelial cell morphology were not due to apoptosis or necrosis, but consisted in fact of cellular remodeling, characterized as epithelial to mesenchymal transitions (EMT) (Demir Weusten et al, 2000; Demir et al., 2003). The molecular nature of the soluble factors from menstrual effluent, which are responsible for the transformation of mesothelial cells from an epithelial to a mesenchymal phenotype is however largely unknown.

Prior to the onset of menstruation a marked influx of bone marrow-derived cells is observed in the endometrium and these cells are also regurgitated into the abdominal cavity during menstruation (D'Hooghe et al., 2001) Menstrual effluent therefore does not only contain fragments of endometrial glands and stroma, but also many leukocytes, such as mast cells, eosinophils, neutrophils and macrophages (Salamonsen and Lathbury, 2000).

Upon arrival in the abdominal cavity menstrual effluent evokes an inflammatory response and attracts large numbers of phagocytic leukocytes from the circulation. Haney and coworkers were the first to report increased numbers of peritoneal macrophages in infertile women with endometriosis (Haney et al., 1981). Hill and coworkers identified various types of leukocytes in peritoneal fluid of patients and reported significant elevations in the number of macrophages, helper T-lymphocytes and natural killer cells (Hill et al. 1988). These leucocytes produce a wide variety of factors, including reactive nitric oxide derivatives, proteases and cytokines which are involved in the degradation and shedding of endometrial tissue during menstruation (Zhang et al., 1998; Garcia-Velasco and Arici, 1999; Chwalisz and Garfield, 2000). 
Nitric oxide (NO) and its reaction products, such as peroxynitrite and 3-nitrotyrosine, have been implicated in a broad range of human diseases and clinical disorders (Ischiropoulos, 1998). These molecular species have been shown to cause loss of epithelial barrier function in several cell types (Hogg, 1998; Eiserich et al., 1999; Knepler et al., 2001) and also to alter cell morphology due to interaction with cytoskeletal proteins. E.g. nitration of $\alpha$ - tubulin or actin results in cell shape changes in several cell types (Eiserich et al., 1999; Knepler et al., 2001). An enzyme responsible for the generation of nitric oxide in a variety of cell types is the inducible form of nitric oxide synthase (iNOS), one of the three known isoforms (Chartrain et al., 1994). In the abdominal cavity there are various sources of nitric oxide during menstruation, such as regurgitated endometrial cells (Tschugguel et al., 1999; Chwalisz and Garfield, 2000), inflammatory cells (Hortelano et al., 1993) and the mesothelium itself (Chen et al, 2000). Activated macrophages and leucocytes produce proteolytic enzymes and reactive oxidative species, such as NO, superoxide radicals and hydrogen peroxide. These short-living intermediates are able to ritrate and oxidize proteins and membrane components, which was shown to result in substantial mesothelial cell damage (Andreoli et al., 1994). The NO and peroxynitrites that are generated outside the mesothelial cell compartments may easily diffuse across cell membranes and interact directly with intracellular targets (Vepa et al., 1997; Ischiropoulos, 1998). Also mesothelial cells are able to produce large amounts of NO when stimulated with certain cytokines such as TNF- $\alpha$, IFN- $\gamma$ and IL-1 $\beta$ (Chen et al., 2000).

Furthermore, proteases, and in particular matrix metalloproteinases (MMPs), have been reported to be involved in epithelial to mesenchymal transitions in several cell types (Pulyaeva et al., 1997; Martorana et al., 1998). Menstrual effluent is a rich source of these enzymes (Koks et al, 2000b), and therefore, these proteases are candidates for the induction of EMT in mesothelial cells.

Numerous studies have demonstrated that soluble paracrine factors, i.e. epidermal growth factor (EGF), hepatocyte growth factor/scatter factor (HCF/SF), trombin, histamine, bradykinin, platelet derived growth factor (PDGF), fibroblast growth factor (FGF), transforming growth factor (TGF), insulin, endothelin and lysophosphatidic acid affect the phosphorylation of proteins involved in signal transduction cascades which lead to morphological changes in various cell types (Levenson and Blackshear, 1989; Hordijk et al., 1994; Chrzanowska-Wodnicka and Burridge, 1996; Lum and Malik, 1996; Boyer et al., 2000; Warn et al., 2001).

The factors in shed menstrual effluent, responsible for EMT in mesothelial cells, are not known. We hypothesize that the EMT in mesothelial cells are induced by soluble factors originated from the menstrual endometrial tissue and/or leucocytes. Likely candidates aie the nitric oxide-related molecules, MMPs, inflammatory cytokines and other proteins and/or peptides.

Therefore, we have evaluated the effect of conditioned media prepared from menstrual effluent cells on the expression of iNOS and the nitration of proteins in relation to the 
changes in mesothelial cell morphology in culture. The possible involvement of MMPs was investigated by blocking MMP activity using broad spectrum inhibitors. Candidate factors were characterized with respect to molecular size, heat lability, and charge, and we attempted to identify the factors using fast protein liquid chromatography, two-dimensional gel electrophoresis and mass spectrometry.

\section{Materials and Methods}

\section{Mesothelial cell isolation and culture}

Human omental tissue was obtained from female patients $(n=5)$, who underwent abdominal surgery for benign gynaecological indications. All patients gave written informed consent. The institutional research review board and the medical ethics committee of the academic hospital approved the study protocol.

Isolation of human omental mesothelial cells (HOMEC) was performed as previously described in detall (Demir Weusten et al., 2000).

Briefly, omental tissue was minced, incubated with collagenase and the undigested tissue was removed with a $400 \mu \mathrm{m}$ stainless sieve. Mesothelial cells, which were retained on a $100 \mu \mathrm{m}$ nylon mesh filter and a $10 \mu \mathrm{m}$ polyamide filter, were resuspended in growth medium. Stromal contaminants were completely removed from mesothelial cells by differential plating. Confluent HOMEC cultures from passage two were used in the experiments.

\section{Preparation of conditioned media}

Menstrual effluent $(n=60)$ was collected by volunteers $(n=8)$ for $2-3$ hours during the first 3 days of menstruation. These women had no history of endometriosis and had regular ovulatory cycles.

Preparation of conditioned media was detaled in our previous report (Demir Weusten et al., 2000). In short, menstrual effluent was centrifuged at $1200 \mathrm{~g}$ for 10 minutes. The serum was removed and referred to as menstrual serum. The remaining tissue was immediately resuspended in routine medium [Dulbecco's modified Eagle's medium (DMEM)/Ham's F-12 supplemented with 10\% fetal calf serum (FCS), penicillin $100 \mathrm{IU} / \mathrm{ml}$, streptomycin $100 \mathrm{\mu g} / \mathrm{ml}$ and $\mathrm{L}-\mathrm{gl}$ lutamine $2 \mathrm{mM}$, amphotericin $0.25 \mathrm{\mu g} / \mathrm{ml}$, from Cibco Life Technologies, Breda, The Netherlands], layered on a HistoPaque 1077 gradient (Sigma-Aldrich Chemie B.V., Zwijndrecht, The Netherlands) and centrifuged at $1200 \mathrm{~g}$ during 30 minutes. Viable cells from the interphase were cultured in routine medium 24 hours at $37^{\circ} \mathrm{C}$ and $5 \% \mathrm{CO}_{2}$. After culture, the medium was removed and was referred to as conditioned medium. Media prepared from different individuals were combined $(n=12)$ and this pool was stored at $-80^{\circ} \mathrm{C}$ until use. For all experiments pooled conditioned media were used unless it is stated otherwise. 


\section{Induction of EMT in HOMEC}

Menstrual serum and conditioned media were tested for their EMT-inducing effect in HOMEC monolayers. Mesothelial cells were grown in 24-well plates until confluency and subsequently cultured overnight in one of the above mentioned preparations. Mesothelial cells cultured in routine medium served as controls for the changes in cell morphology.

\section{Expression of iNOS $m R N A$}

HOMEC were cultured overnight either in routine medium or in unpooled conditioned media from different individuals. After removal of the medium total RNA was extracted and purified using TRIZOL reagent, according to the instructions of the manufacturer (Gibco Life Technologies, Breda, The Netherlands). Equal amounts of RNA (400 ng) from each sample were reverse-transcribed to single-stranded cDNA with an oligo(dT) primer and reverse transcriptase (Promega, Leiden, The Netherlands). Thereafter, PCR was performed in $20 \mu$ l of reaction solution containing $0.3 \mathrm{mM} \mathrm{MgCl}_{2}, 1$ IU AmpliTaq DNA polymerase (Perkin Elmer, München, Germany), $20 \mu \mathrm{M}$ oligonucleotide primers (5'-GCCTCGCTCTGGAAAGA-3' sense, 5'-TCCATGCAGACAACCTT-3' antisense, from Eurogentec, Maastricht, The Netherlands) and $4 \mu \mathrm{l}$ of the CDNA from the reverse transcriptase reaction. Following an initial denaturation step at $94^{\circ} \mathrm{C}$ for 1 minute, the iNOS fragment was amplified in 35 cycles at an annealing temperature of $60^{\circ} \mathrm{C}$. For semiquantitative PCR, $20 \mu \mathrm{M}$ of specific oligonucleotide primers for GAPDH (5'-CGTCTTCACCACCATCGAGA-3' and 5'-CGGICCATCACCCCACACTTT-3') was added to the reaction after 12 cycles. The expected band size is 499 bp for the iNOS fragment (Gradini et al., 1999) and 300 bp for the GAPDH fragment. mRNA isolated from anterogradely shed menstrual effluent cells was. used as a positive control for the RT-PCR procedure (Telfer et al., 1997).

\section{Immunofluorescence staining of nitrated tyrosines}

HOMEC were seeded in multi-chamber slides (Lab-Tek II, Nunc) and grown to confluency. After culturing overnight either in routine medium or in conditioned media, HOMEC monolayers were fixed in methanol for 10 minutes at $-20^{\circ} \mathrm{C}$. After rinsing with phosphate: buffered saline (PBS), sections were blocked in 10\% goat serum and 2\% bovine serum albumin for 1 hour at $25^{\circ} \mathrm{C}$, and incubated with rabbit anti-human 3-nitrotyrosine (diluted 1:100, Upstate Biotechnology) overnight at $4^{\circ} \mathrm{C}$. Immunostaining was visualized with Cy3conjugated goat anti-rabbit IgG (diluted 1:500, Amersham Pharmacia Biotech, Roosendaal, The Netherlands). 4',6-diamidine-2'-phenylindole dihydrochloride (DAPI, $1 \mu \mathrm{g} / \mathrm{ml}$ ) was used for nuclear counterstaining. As a positive control for the anti-nitrotyrosine staining, mesothelial cells were treated with $35 \mathrm{mM}$ peroxynitrite (Viera et al., 1999) 
Sections were viewed with a fluorescence microscope (Zeiss, Axioskop) and recorded with an imaging analysis software package (In situ imaging system, ISIS).

\section{Electrophoresis and Western blotting of nitrated proteins}

Confiuent monolayers of HOMEC were cultured overnight, either in routine medium or in pooled conditioned media. After rinsing cells several times with DMEM, the cells were lysed with lysis buffer containing $20 \mathrm{mM}$ Tris HCl, pH $8,137 \mathrm{mM} \mathrm{NaCl}, 1 \mathrm{mM} \mathrm{MgCl}, 1 \mathrm{mM} \mathrm{CaCl}_{2}$, 10\% glycerol, 1\% Triton X-100, $1 \mathrm{mM}$ phenylmethylsulphonyl fluoride and protease inhibitor cocktail (Boehringer, Almere, The Netherlands). The lysates were centrifuged for 15 minutes at $4^{\circ} \mathrm{C}$. The protein concentration in the supernatants was determined using a BCA assay (Sigma-Aldrich).

The proteins (40 $\mu \mathrm{g} /$ lane) were separated on a 12\% SDS-PACE gel, stained with Coomassie Blue, and transferred to a nitrocellulose membrane (Schleicher and Schuell). Non-specific sites were blocked by 3\% non-fat dry milk in PBS containing $0.1 \%$ Tween 20 overnight at $4^{\circ} \mathrm{C}$. After washing with PBS three times 5 minutes each, the blot membrane was incubated with mouse anti-human 3-nitrotyrosine antibody (diluted 1:750, Kordia Life Sciences) for 2 hours at room temperature. The blot membrane was washed three times for 10 minutes each in TBS with $0.1 \%$ Tween-20 and then incubated with horseradish peroxidase-conjugated goat anti-mouse IgG (diluted 1:1000, Sigma-Aldrich) for 2 hours at room temperature. The 3-nitrotyrosine antibody was detected by enhanced chemiluminescene using ECL detection reagents (Amersham Pharmacia). The bands were analysed and visualized with the Fluoro S Imager (Biorad, Veenendaal, The Netherlands) or exposure to Kodak Biomax ML X-ray film.

\section{Heat treatment}

In order to test whether the inducing factors are heat-labile, both routine medium and conditioned media were incubated at $95^{\circ} \mathrm{C}$ for 15 minutes and evaluated for induction of EMT in confluent HOMEC monolayers.

\section{Adsorption to anion and cation exchangers}

The inducing factors in conditioned media were characterized with respect to their charge. To bind anionic factors the ion exchange resin QAE Sephadex A-50 and for adsorption of cationic factors SP Sephadex C-50 (both were from Amersham Pharmacia) were added to routine medium or conditioned media in $1: 1$ dilution ( $v: v)$ and incubated for 2 hours at $4^{\circ} \mathrm{C}$ on a rollerbank. Subsequently, the mixture was centrifuged at $500 \mathrm{~g}$ for $10 \mathrm{~min}$ utes. The supernatant, which contained the factors that did not bind to the anion or cation resins were tested on confluent HOMEC monolayers for induction of EMT. 


\section{Size fractionation}

Routine medium and conditioned media were separated into two fractions using a centrifugal filter device with a cut-off value at a molecular weight of $50 \mathrm{kD}$ (Centricon-Millipore). Both fractions were tested on HOMEC monolayers and the fraction which induced the morphological changes was further processed for gel filtration chromatography.

Proteins in the region larger than $50 \mathrm{kD}$ were fractionated on the basis of their molecular weight. The fractions were concentrated (1Ox) during centrifugation with a fiter device and fractionated by fast performance liquid chromatography (FPLC) using a Superdex-200 column 3 (Amersham Pharmacia) and BioLogic HR System (Biorad). The separating range was $10-600 \mathrm{kD}$. The samples were eluted with PBS $(\mathrm{PH} 7.4)$ or $10 \mathrm{mM}$ $\mathrm{NH}_{4} \mathrm{HCO} ;(\mathrm{pH} 7.4)$ and the fractions from each separate peak were pooled, snap frozen and lyophilized.

After correcting for the dilution factor, each pool of collected fractions was tested for its damaging effect on confluent HOMEC monolayers.

\section{Two-dimensional protein analysis}

2D-PACE was performed by combining isoelectric focusing (IEF, first dimension) and sodium dodecyl sulfate-polyacrylamide gel electrophoresis (SDS-PAGE, second dimension) (Görg et al., 2000). Briefly, lyophilized and acetone-TCA precipitated samples were dissolved in buffer containing $40 \mathrm{mM}$ Tris, $8 \mathrm{M}$ urea, 4\% CHAPS, 0.5\% Pharmalytes 3-10 (Amersham Pharmacia), 1\% DT and protease inhibitor cocktail (Boehringer). Protein concentration was determined with the PlusOne 2-D Quant Kit (Amersham Pharmacia). Electrophoresis in the first dimension was carried out using an IPGphor apparatus with immobilized $\mathrm{pH}$ gradient strips ( $\mathrm{pH}$ range 3-10, Amersham Pharmacia). Samples with equal protein amounts were applied to the strips. for 12-16 hours in rehydration solution which contained $8 \mathrm{M}$ urea, $2 \%$ CHAPS, 0.5\% Pharmalytes 3-10, 0.7\% DT and protease inhibitor cocktail. Samples of $100 \mu \mathrm{g}$ (for analytical gels) and $750 \mu \mathrm{g}$ (for micropreparative gels) protein were loaded per strip. Isoelectric focussing was carried out at $20^{\circ} \mathrm{C}$ for a maximum of $50 \mu \mathrm{A} / \mathrm{strip}$ with gradually increasing voltage $(200 \mathrm{~V}, 500 \mathrm{~V}, 1000 \mathrm{~V}$ each for I hour, gradual increase to $8000 \mathrm{~V}$ for another hour, $8000 \mathrm{~V}$ for 12 hours). The focussed strips were stored at $-70^{\circ} \mathrm{C}$.

Electrophoresis in the second dimension was carried out with the Ettan-Dalt vertical system (Amersham Pharmacia), using homogenous (12\% T, 2.6\% C, thicknessi $1 \mathrm{~mm}$ ) SDSPAGE gels. IPG strips were equilibrated for two times 15 minutes in $6 \mathrm{M}$ urea, $35 \% \mathrm{v} / \mathrm{v}$ glycerol, 3\% W/v SDS, $50 \mathrm{mM}$ Tris- $\mathrm{HCl}, \mathrm{pH} 8.8,1 \mathrm{mM}$ EDTA, containing $1 \% \mathrm{~W} / \mathrm{v}$ DT and $4 \%$ iodoacetamide for the first and second period of equilibration, respectively. The strips were placed on the gels, overlayed with $0.5 \%$ agarose and subject to electrophoresis at $5 \mathrm{~W} /$ gel for 1 hour followed by $120 \mathrm{~W}$ maximum for 4 hours at $20^{\circ} \mathrm{C}$, using Tris-Clycine-SDS 
as running buffer. Gels were fixed in $40 \%$ ethanol and 10\% acetic acid. For spot analysis gels were silver stained (Heukeshoven and Dernick, 1988). The gels prepared for mass spectrometry analysis were stained with the fluorescent dye Syproruby, according to manufacturer's recommendations (BioRad). 2D-PAGE profiles were scanned with a GS-800 for silver-staining or a FX-Multimage laser densitometer for SyproRuby-staining (BioRad).

The comparative analysis was performed using PD-Quest software (BioRad). Only those spots that were clearly present or completely absent in either the routine medium or in conditioned media were taken as spots of interest. Spots from multiple gels $(n=8)$ were excised using a spot picker apparatus (Biorad), pooled and subjected to mass spectrometry analysis of peptide mass fingerprints.

\section{Protein identification with mass spectrometry}

The excised gel pieces were washed and digested in-gel overnight with trypsin (sequencing grade, Promega, Madison WI, USA). A sample of $2 \mu$ l was taken for mass spectrometry analysis using a automated in-gel digestion robot (Biorad). Peptide mass finger printing was performed using matrix-assisted laser desorption/ionization time-of-flight (MALDI TOF, Micromass). Calibration was accomplished by using external mass standards. Protein identification was performed by searching the peptide mass maps in SwissProt and NCBI databases using a mass links global protein server (Micromass).

\section{Prevention of EMT with the inhibitor of matrix metalloproteinases}

To test whether matrix metalloproteinases were involved in EMT, HOMEC monolayers were cultured overnight in routine medium or conditioned media with GM 6001 (Chemicon, Temecula CA, USA), a general inhibitor of matrix metalloproteinases, in the concentrations $10 \mu \mathrm{M}, 25 \mu \mathrm{M}, 50 \mu \mathrm{M}, 150 \mu \mathrm{M}$ and $200 \mu \mathrm{M}$.

\section{Results}

\section{Epithelial to mesenchymal transitions in mesothelial cells}

The EMT in mesothelial cells, which were induced by menstrual sera and by conditioned media prepared from shed menstrual effluent, are shown in Figure 1. In control culture conditions, the mesothelial cells display morphological features of epithelial cells, whereas after culture in menstrual sera and conditioned media cell-cell contacts were dissociated and mesothelial cells gained a mesenchymal-like morphology (see also http://www.grow.unimaas.nl/biology_merg_movies.htm). 

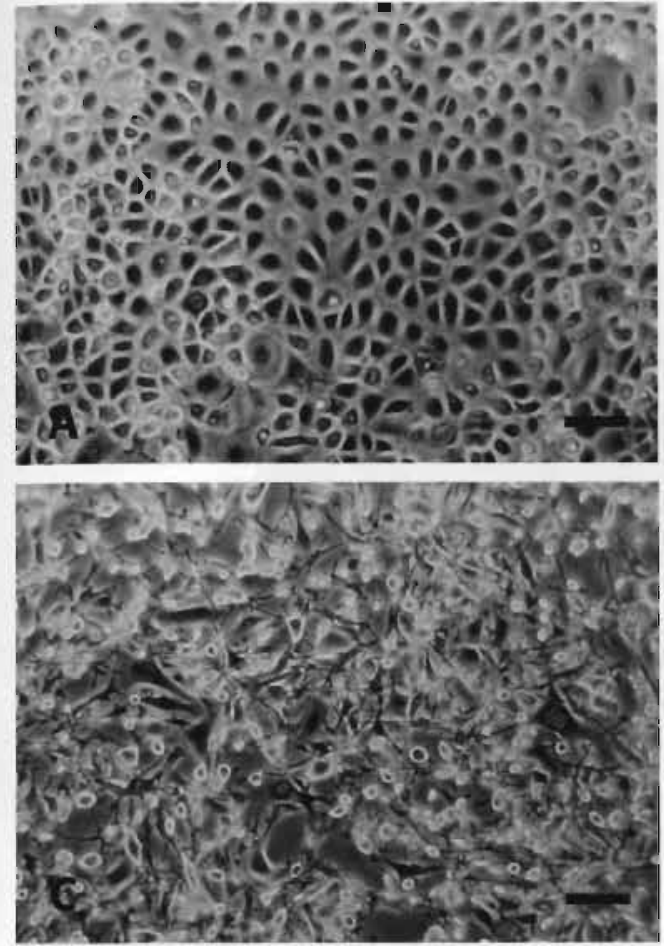

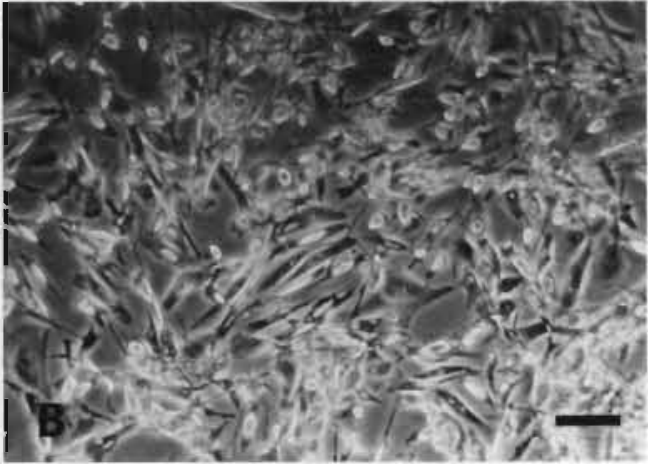

Figure 1: Menstrual sera and conditioned media induce epithelial to mesenchymal transitions in mesothelial cells. (A) Routine medium; (B) menstrual sera; (C) conditioned media. Scale bars represent $100 \mu \mathrm{m}$.

\section{Production of NO and nitrotyrosination}

The iNOS gene product was found in cells isolated from shed menstrual effluent, and in HOMEC cultured with unpooled conditioned media prepared from different individuals, as shown in Figure 2. However, a large inter-individual variation in the intensities of iNOS mRNA signals was apparent. Mesothelial cells cultured in routine medium also expressed low levels of iNOS mRNA (Figure 2).

Mesothelial cells cultured either in routine medium or in conditioned media showed no significant differences in the immunoreactivity for anti-3-nitrotyrosine (Figure 3). Both conditions demonstrated a low level of staining. Peroxynitrite treatment of mesothelial cells, used as a positive control for the nitration of proteins, resulted in a granular staining pattern in the cytoplasm as compared to cells without peroxynitrite (Figure 3).

Western blots of proteins obtained from whole cell lysates after incubation in either routine medium or conditioned media, showed clear bands for 3-nitrotyrosine immunoreactivity (Figure 4). In order to ensure careful comparison of both conditions equal amounts of protein were loaded on the SDS-PAGE gels which were run in parallel. Similar staining patterns were observed in both conditions. 

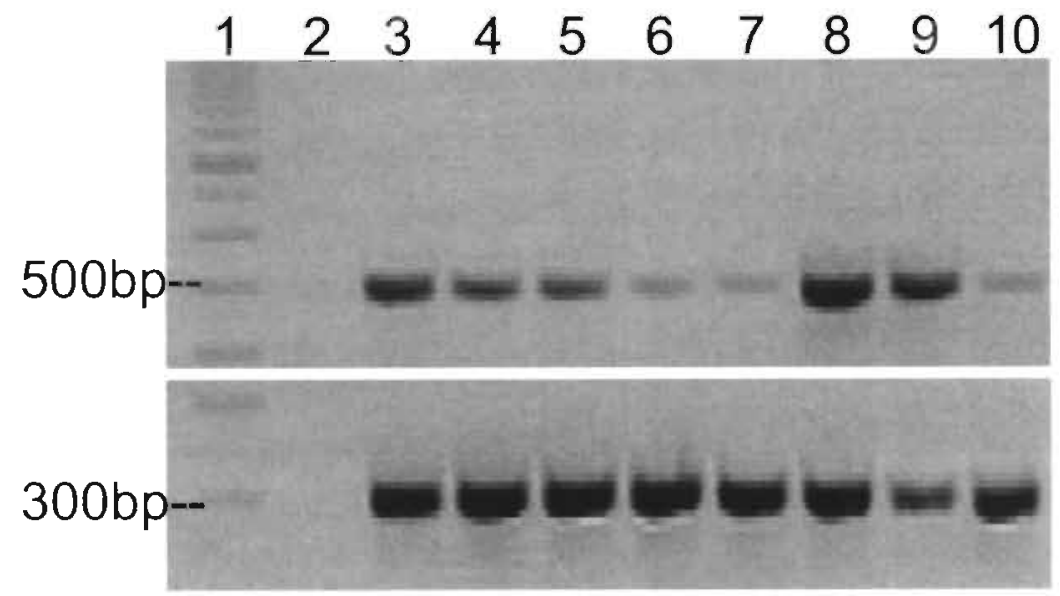

Figure 2: iNOS expression in mesothelial cells cultured overnight in routine medium or conditioned media. From left to right: 100 bp ladder (lane 1), negative control (lane 2), iNOS expression in cells isolated from menstrual effluent (positive control, lane 3), iNOS expression in HOMEC after culture in conditioned media prepared from different individuals (lanes 4-9) and iNOS expression in HOMEC cultured with routine medium (lane 10). GAPDH expression is displayed in the lower panel.
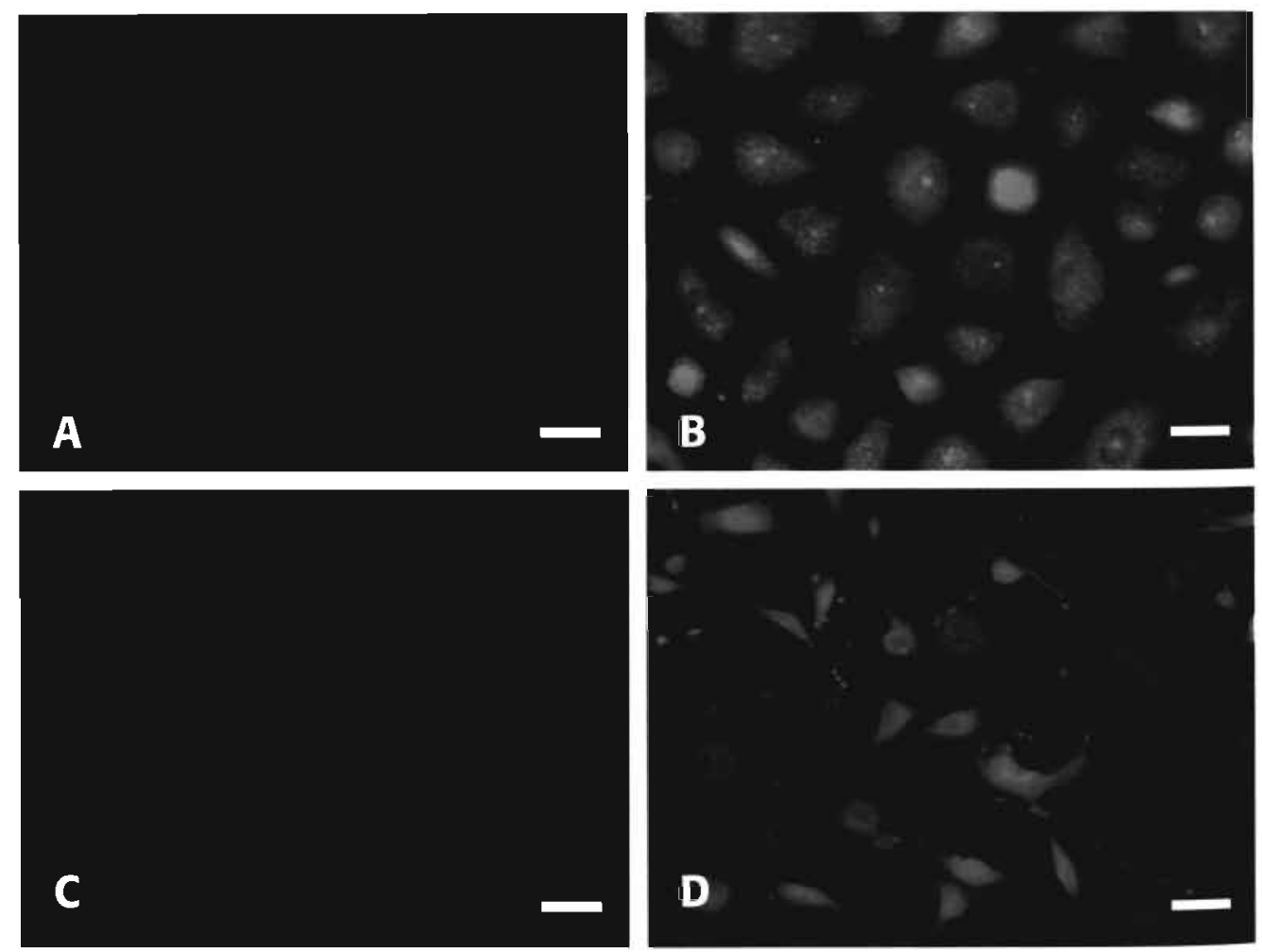

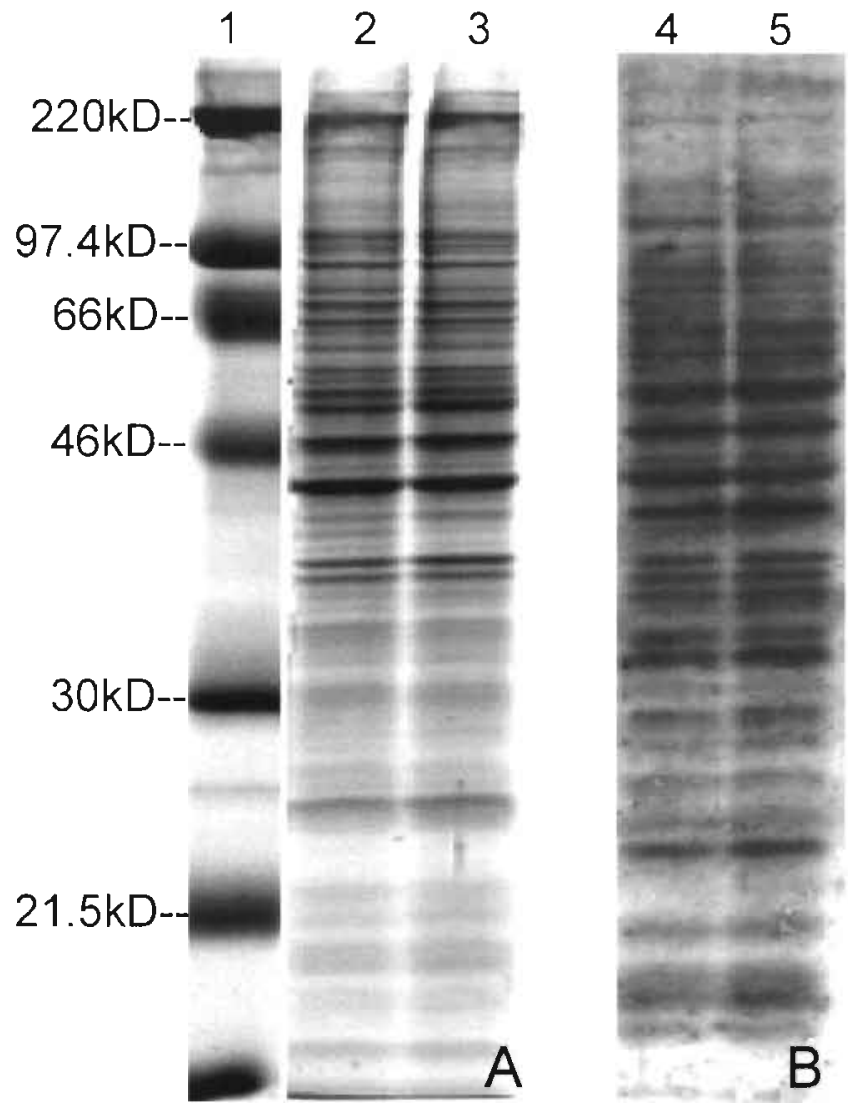

Figure 4: Protein nitration in mesothelial cells. (A) SOS-PACE of cellular proteins stained with Coomassie Blue showing: the protein size markers (lane 1), whole cell lysate of mesothelial cells cultured in routine medium (lane 2), and whole cell lysate of mesothelial cells cultured in conditioned media (lane 3). (B) Western blots: immunoreactivities for nitrated proteins isolated from mesothelial cells cultured in routine medium (lane 4) and conditioned media (lane 5).

Figure 3: Nitrotyrosine staining in mesothelial cells after overnight culture in routine medium or conditioned media. (A) Negative control: HOMEC cultured in routine medium without primary antibody in the staining procedure; (B) positive control: peroxynitrite treated mesothelial cells show anti-nitrotyrosine staining: (C) routine medium and (D) conditioned medio. Scale bars represent 40 um. 


\section{Heat lability, charge and size of inducing factors}

Heating of the conditioned media at $95^{\circ} \mathrm{C}$ abolished the EMT in mesothelial cells since a morphology as in Figure 5C was seen.
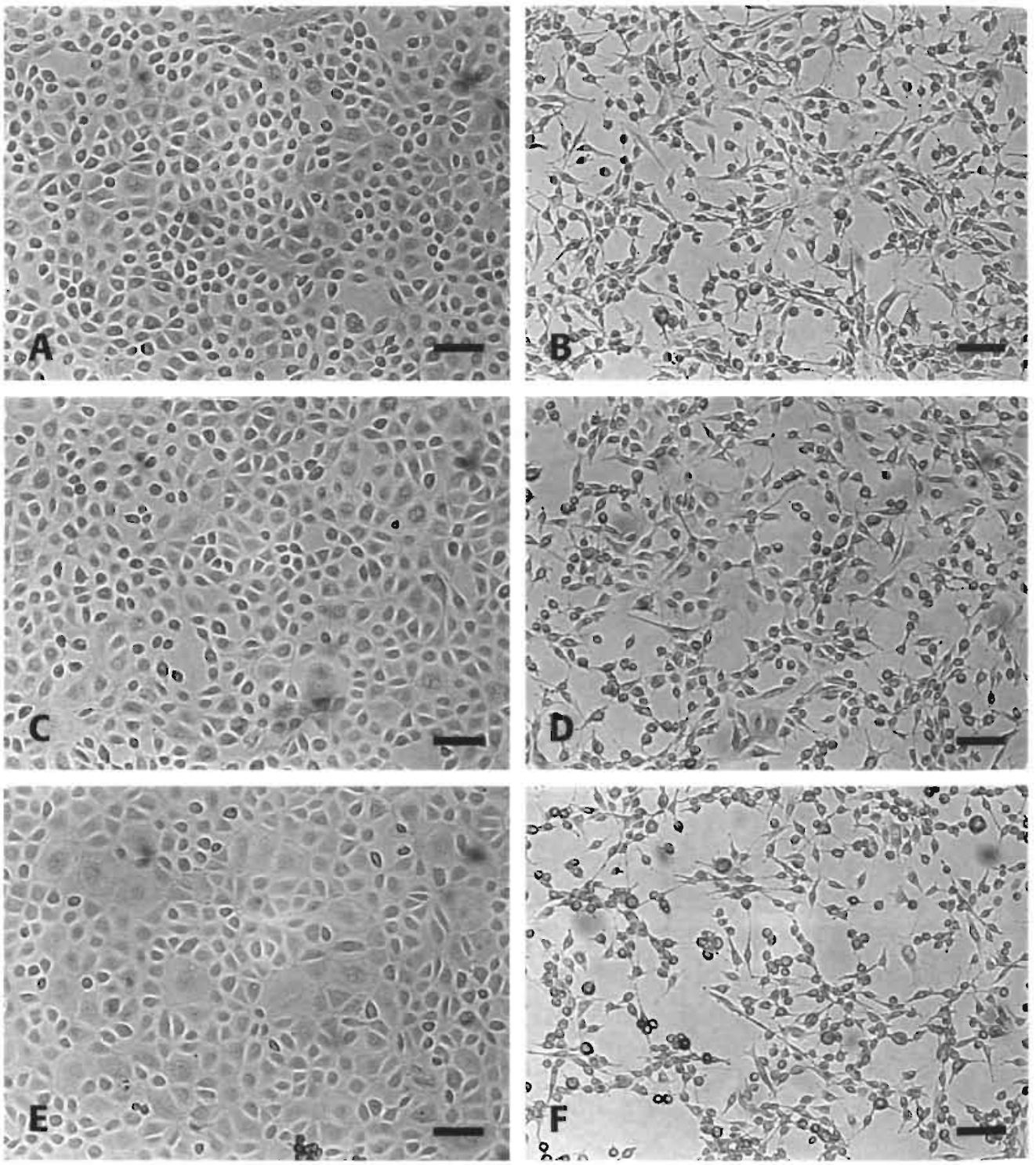

Figure 5: Effects of various manipulations on the EMT-inductive properties of conditioned medium. (A) routine medium; $(B)$ conditioned media; (C) heat-inactivated conditioned media; $(D)$ conditioned media fraction $>50 \mathrm{kD}$; $(E)$ routine medium after anion exchange column; $(F)$ conditioned media after anion exchange column. Scale bars indicate 100 um. 
The inducing factors in conditioned media were characterized with respect to their charge by binding experiments with ion exchange resins. The supernatants which contained factors that did not bind to anion- or cation- exchangers were tested on confluent HOMEC, monolayers. Both types of supernatant induced the EMT as observed in representative Figures $5 E$ and $5 F$.

Subsequently the size of the inducing factor(s) was assessed. The two fractions obtained after filter centrifugation were tested for effects on the HOMEC morphology. The fraction with molecules larger than $50 \mathrm{kD}$ induced the morphological alterations as seen in Figure $5 \mathrm{D}$, whereas the fraction which contained the molecules smaller than $50 \mathrm{kD}$ did not.

Gel filtration chromatography of the fraction with molecular weights above $50 \mathrm{kD}$ resulted in similar chromatograms for routine medium and conditioned media (Figure 6). Representative samples from various regions of the elution profile as indicated in Figure 6 were tested for induction of EMT in mesothelial cells. Only samples from peak $A$, including the albumin fraction, obtained from conditioned media, but not from routine medium, contained the inducing factor(s). Similar results were obtained for preparations of conditioned media obtained from various individuals $(n=5)$.

\section{Fractions}

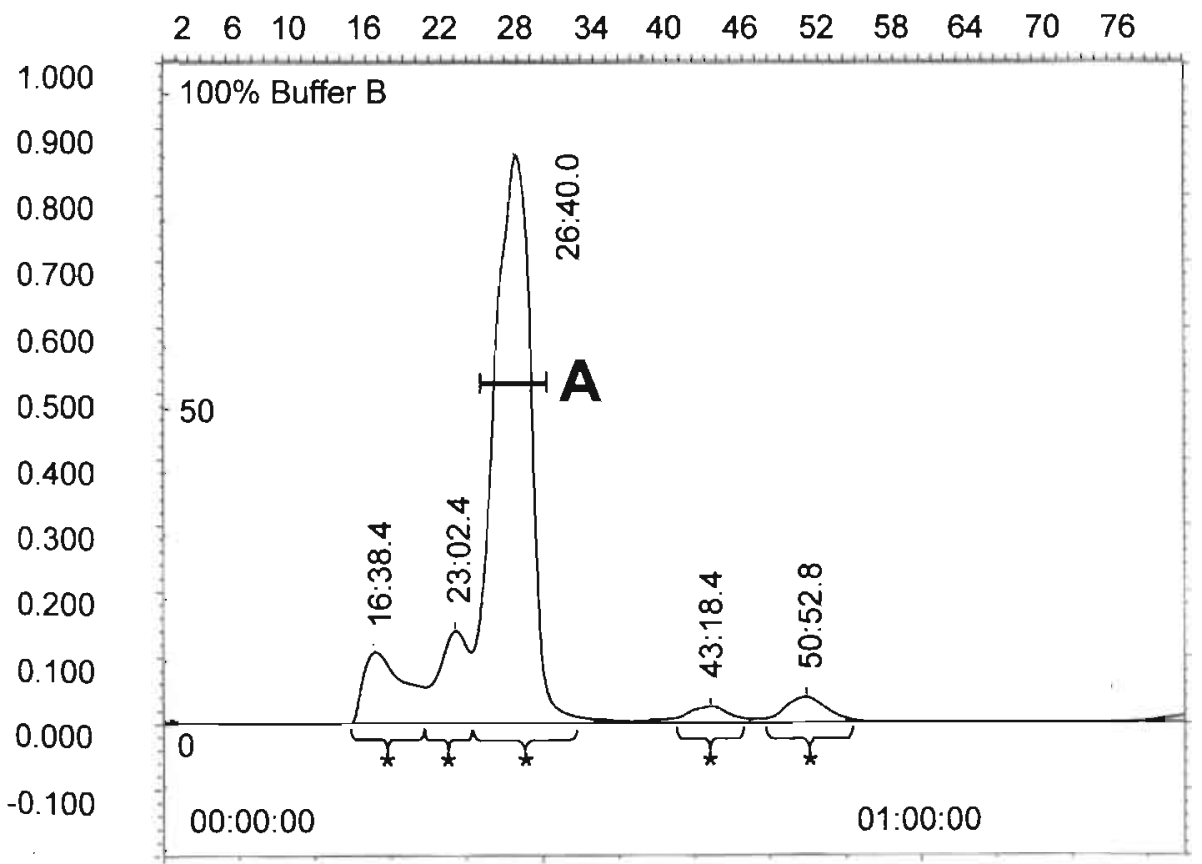

500.0

450.0

400.0

350.0

300.0

250.0

200.0

150.0

100.0

50.0

0.0

$-50.0$

$A U$

Hr:Min:Sec

$\mathrm{mS} / \mathrm{cm}$

Figure 6: Chromatogram of conditioned media by fast performance liquid chromatography. The fractions indicated with an asterisk (*) represent those fractions that were tested for their EMTinducing potential. This was found in the albumin fraction (A). 


\section{Comparative 2D-PAGE analysis and molecular identification}

The proteins in fraction A obtained after size fractionation of conditioned media on FPLC were further separated by two-dimensional polyacrylamide gel electrophoresis (2D-PAGE). Comparative analysis of the gels revealed that at least 11 proteins, with a molecular weight smaller than aibumin, were only present in conditioned media (Figure 7). These spots were excised from eight gels, pooled and used for peptide fingerprint analysis with mass spectrometry. The three subunits of two proteins that could be identified were $\alpha$-enolase (accession number P06733, MW 47 kD, pl 7.5), haemoglobin- $\alpha$ (accession number P01922, MW 10.5 kD, pl 9) and haemoglobin- $\beta$ (accession number P02023, MW 15.9 kD, pl 7.3). For the other seven spots the peptide fingerprints could not 12 matched in any of the databases used, mainly due to the very small amounts of proteins that could be recovered from the gels.

\section{Inhibition of matrix metalloproteinases}

It was evaluated whether matrix metalloproteinases were involved in EMT of mesothelial cells. Concentrations of the general matrix metalloproteinase inhibitor GM600 1 between 10 and $50, \mathrm{uM}$ failed to prevent the alterations induced by conditioned media. Higher concentrations, however, resulted in cell death (Figure 8).

Figure 7: Two-dimensional gel electrophoresis of routine medium (RM) and conditioned media (CM). Arrows show proteins specifically present in the conditioned media and not in the routine medium ( $1 \& 2=\alpha$-enolase; $3=$ haemoglobin- $\alpha ; 4=$ haemoglobin- $\beta$ ). 


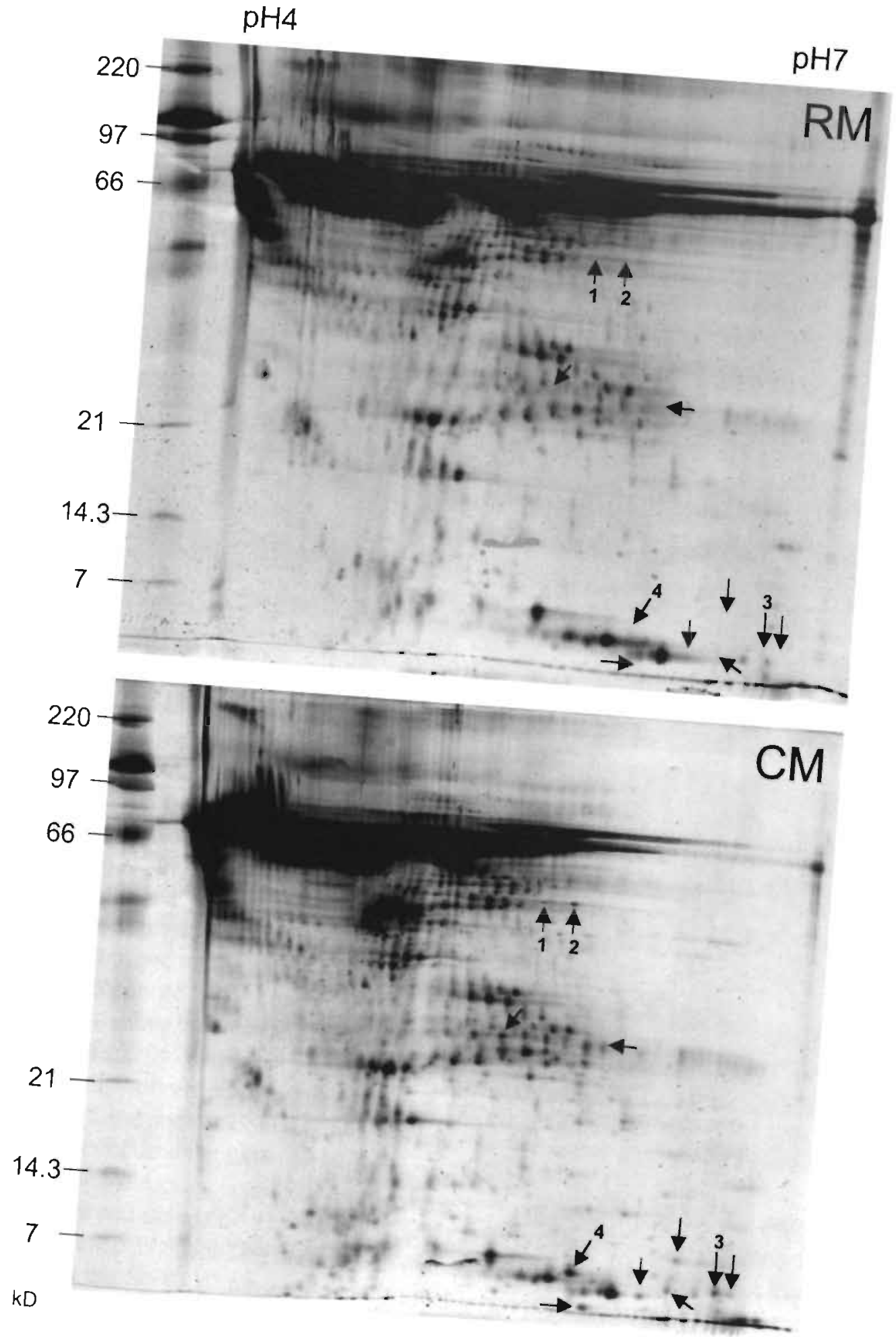



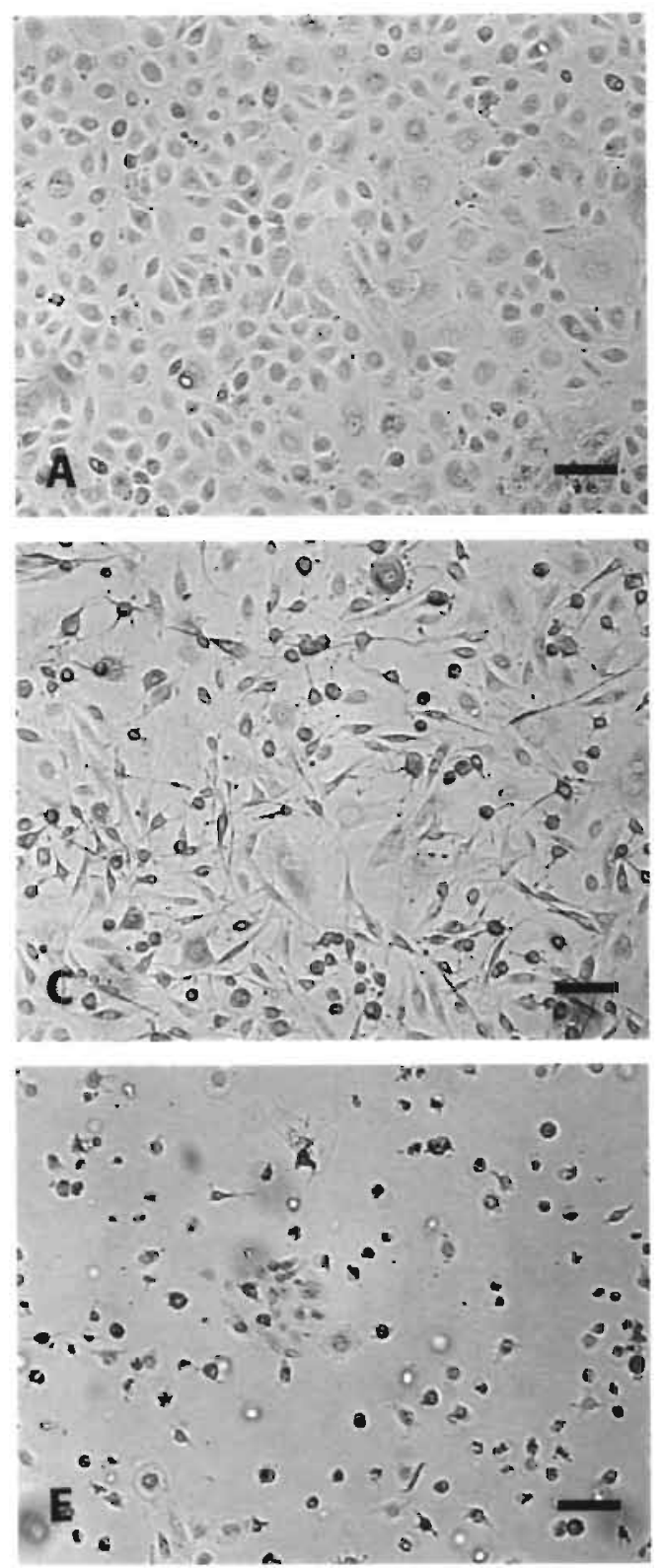
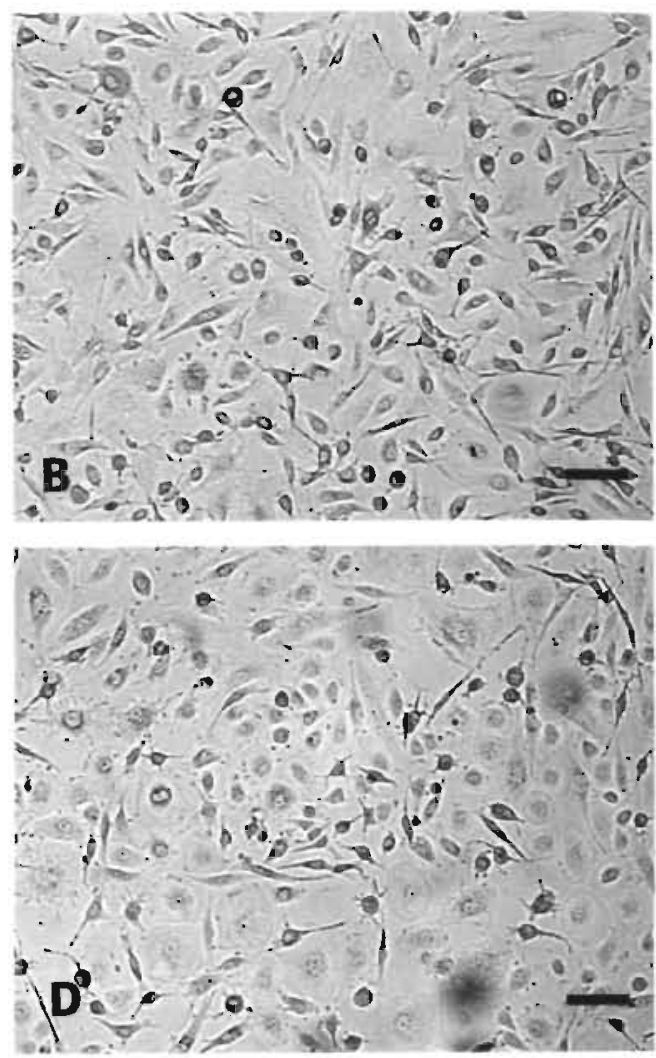

Figure 8: Co-incubation of conditioned media with the MMP inhibitor GM6000 does not inhibit or reverse the EMT process. (A) Routine medium; $(B)$ conditioned media; conditioned media with (C) $10 \mu \mathrm{M},(D) 50 \mu \mathrm{M},(E) 100 \mu \mathrm{M}$ of inhibitor. Scale bars indicate 100 um. 


\section{Discussion}

Soluble factors from menstrual effluent present in conditioned media induce epithelial to mesenchymal transitions in mesothelial cells in vitro (Demir et al., 2003). Previously we have demonstrated that endometrial fragments or isolated epithelial and stromal cells obtained from endometrium in the proliferative or secretory phase do not induce morphological changes (Koks et al., 2000a). This suggests that factors unique for endometrium during menstruation are responsible for the mesothelial EMT. This reversible process may lead to exposure of extracellular matrix and to the creation of adhesion substrates for endometrium tissue fragments in vivo (Koks et al., 1999; Demir Weusten et al., 2000; Koks et al, 2000a).

In this study no evidence was found for involvement of $\mathrm{NO}$ and its reaction products in mesothelial EMT in vitro. Most of the conditioned media prepared from shed menstrual endometrium were able to induce iNOS expression in monolayer cultures of mesothelial cells. However, several observations indicate that this phenomenon has only, if at all, a minor role in the induction of EMT in mesothelial cells. A large individual variation was observed in conditioned media induced iNOS expression. This may be explained by the differences that exist in the amount and composition the menstrual effluent which will depend on the individual, the phase of the menstrual cycle and even the time of menstrual effluent collection. In contrast, all conditioned media induced obvious changes in mesothelial cell morphology, and without individual variation. Thus, menstrual effluents have a variable potential of inducing iNOS expression. In addition, mesothelial cells show a low constitutive expression of iNOS, irrespective of incubation in conditioned or control media, i.e. also in cells that do not show any changes in morphology. Therefore we do not find evidence that stimulation of iNOS gene expression by menstiual effluent is involved in the induction of EMT in mesothelial cells.

In control experiments proteins with nitrated tyrosines were seen as a granular staining distributed homogenously in the cell cytoplasm and in some cells the staining around the nuclei was stronger. Staining intensity was similar for cells either cultured in routine medium or in conditioned media, which indicates that the level of nitrotyrosines in mesothelial cells was not enhanced by the conditioned media. Also, Western blot analysis of 3-nitrotyrosine immunoreactivity in mesothelial cell lysates showed similar patterns of nitrated proteins in mesothelial cells cultured in either routine medium or conditioned media. Apparently, nitration of tyrosines is a constitutive process occurring in vitro in mesothelial cells. Taken together, these findings do not provide evidence for involvement of NO and protein nitration in the induction of EMT in mesothelial cells.

The soluble factors from cells in menstrual effluent responsible for the EMT were heat-labile and did not bind to the anion- and cation-exchangers, which indicates that the factor(s) are $\mathrm{pH}$ neutral. Size fractionation demonstrated that the factors have a molecular weight in the 50-70 kD range and are present in the albumin fraction. In an attempt to 
identify mesothelial cell injury factors in rat tumour ascites, Kimura and coworkers also found the effect to be mediated by the albumin fraction. In contrast to our observations, however, these authors observed that low-molecular weight fractions were able to cause these effects as well (Kimura et al., 1985).

After 2D-PAGE analysis of the albumin fraction, several proteins were found to be present only in conditioned media. Surprisingly however, the unique proteins present in conditioned media had molecular weights much smaller than that of albumin. It could be that the factors are loosely bound to albumin, are part of protein complexes or are subunits of multimeric proteins. We can not exclude, however, that other proteins are undetectable because they are masked by the high abundance of albumin and other serum proteins, due to similarities in size and charge and the adhesive nature of many serum proteins.

Mass spectrometry analysis of the protein spots that were distinctively present in conditioned media, resulted in the unambiguous identification of three subunits of two proteins, $\alpha$-enolase, a dimeric enzyme from the glycolytic pathway, and haemoglobin $\alpha$ and $\beta$, subunits of the multimeric protein haemoglobin.

$\alpha$-Enolase is a plasminogen receptor and has been found in human endometrium (Byrjalsen et al., 1999; Pancholi, 2001; Graven et al., 2002). Hypoxic stress, as occurs in endometrium during menstruation, was shown to increase a-enolase expression (Byrjalsen et al., 1999; Critchley et al., 2001). $\alpha$-Enolase is also known as a substrate for Sic protein tyrosine kinase signaling pathway, which has been reported to be involved in EMT (Kellie et al., 1991; Boyer et al., 2000; Timpson et al., 2001). Therefore, $\alpha$-enolāse is a candidate as an EMT-inducing factor in menstrual effluent.

The presence of haemogiobin in conditioned media is probably due to lysed erythrocytes in the menstrual effluent. Several studies performed in rats have demonstrated that haemoglobin induces interendothelial gaps and albumin leakage in the mesentery as well as epithelial damage to the intestinal mucosa (Baldwin, 1999; Baldwin and Wiley, 2002). These actions of haemoglobin are most likely the result of changes in the endothelial actin cytoskeleton through tyrosine kinase signaling (Vollrath et al., 1998; Baldwin, 1999; Patlolla et al., 1999), which renders it a candidate inducer of EMT in mesothelial cells. This assumption is supported by our experiments with sodium azide, which is known to have a high affinity to haemoglobin (Demir et al., 2003). It is possible that this EMT-inducing action of haemoglobin is neutralized by sodium azide in mesothelial cells.

Matrix metalloproteinases, most of which have a molecular weight larger than $50 \mathrm{kD}$, are abundantly present in endometrium during menstruation and would be strong potential candidates for inducing EMT. However, the incubation with the broad spectrum matrix metalloproteinase inhibitor GM600 1 failed to prevent the alterations. This makes a role of MMPs in menstrual effluent induced EMT unlikely.

In conclusion, the epithelial to mesenchymal transitions in mesothelial cell monolayers induced by anterogradely shed menstrual effluent can not be explained by protein nitration through reactive nitric oxide derivatives or by involvement of matrix metalloproteinases. The 
soluble factor(s) from menstrual effluent are characterized by heat lability, a neutral charge and an apparent molecular weight of 50-70 kD. The exact roles of $\alpha$-enolase and haemoglobin, which have been identified by mass spectrometry analysis and database search, in EMT of mesothelial cells have to be further clarified. Also, molecular identification of the other factor(s) involved in EMT of mesothelial cells, requires further study.

\section{Acknowledgements}

The authors like to acknowledge drs. C.G.M. Heinnen (Department of Pharmacology and Toxicology, Maastricht University) for supplying the peroxynitrite, Mr. Barry Jütten for his skills in chromatography technique, ing. G.C. de Veen and ing. N. Kisters for their excellent technical support and $\mathrm{Mr}$. Freek Bouwman for his contributions in mass spectrometry analysis (Maastricht Proteomic Center, Maastricht University).

\section{References}

Andreoli, S. P., Mallett, C., Williams, K., McAteer, J. A., Rothlein, R. and Doerschuk, C. M. (1994) Mechanisms of polymorphonuclear leukocyte mediated peritoneal mesothelial cell injury. Kidney int, 46, $1100-1109$.

Baldwin A. L. (1999) Modified hemoglobins produce venular interendothelial gaps and albumin leakage in the rat mesentery. Am I Physiol, 277, H650-659.

Baidwin, A. L. and Wiley, E. B. (2002) Selenium reduces haemoglobin-induced epithelial damage to intestinal mucosa. Artif Cells Blood Substit immobil Biotechnol, 30, 1-22.

Boyer, B., Valles, A. M. and Edme, N. (2000) induction and regulation of epithelial-mesenchymal transitions. Biochem Pharmacol, 60, 1091-1099.

Byrjalsen, I., Mose Laisen, P., Fey, S. J., Nilas, L., Larsen, M. R. and Christiansen, C. (1999) Twodimensional gel analysis of human endometrial proteins: characterization of proteins with increased expression in hyperplasia and adenocarcinoma. Mol Hum Reprod, 5, 748.756.

Chartrain, N. A.r Geller, D. A., Koty, P. P., Sitrin, N. F., Nussler, A. K., Hoffman, E. P., Billiar, T. R., Hutchinson, N. I. and Mudgett, J. S. (1994) Molecular cloning, structure, and chromosomal localization of the human inducible nitric oxide synthase gene. J Biol Chem, 269, 6765-6772.

Chen, J. Y., Chiu, J. H., Chen, H. L., Chen, T. W., Yang, W. C. and Yang, A. H. (2000) Human peritoneal mesothelial cells produce nitric oxide: induction by cytokines. Perit Dial int, 20, 772-777.

Chreanowska-Wodnicka, M. and Burridge, K. (1996) Rho-stimulated contractility dives the formation of stress fibers and focal adhesions. I Cell Biol, 133, 1403-1415.

Chwalisz, K. and Garfield, R. E. (2000) Role of nitric oxide in implantation and menstruation. Hum Reprod, 15 Supp! 3, 96-111.

Critchley, H. O., Kelly, R. W., Brenner, R. M. and Baird, D. T. (2001) The endocrinology of menstruation-a role for the immune system. Clin Endocrinol, 55, 701-710

Demir, A. Y., Groothuis, P. G., Nap, A. W., Punyadeera, C., de Goeij, A. F., Evers, 1. L. H. and Dunselman, G. A. (2004) Menstrual effluent induces epithelial to mesenchymal transitions in mesothelial cells. Hum Reprod, 19, 21-29.

Demir Weusten, A. Y., Groothuis, P. G., Dunselman, G. A. de Goeij, A. F., Arends, J. W. and Evers, 
J. L. (2000) Morphological changes in mesothelial cells induced by shed menstrual endometrium in vitro are not primarily due to apoptosis or necrosis. Hum Reprod, 15, 1462-i468.

D'Hooghe, T. M., Bambra, C. S., Xiao, L., Peixe, K. and Hill, I. A. (200i1) Effect of menstruation and intrapelvic injection of endometrium on inflammatory parameters of peritoneal fluid in the baboon (Papio anubis and Papio cynocephalus). Am J Obstet Gynecol, 184, 917'-925.

diZerega, G. S. (1997) Biochemical events in peritoneal tissue repair. Eur J Surg Suppl, 577, 10-16. Eiserich, J. P., Estevez, A. G., Bamberg, T. V., Ye, Y. Z., Chumley, P. H., Beckman, J. S. and Freeman, B. A. (1999) Microtubule dysfunction by posttranslational nitrotyrosination of $a$-tubulin: a nitric oxide-dependent mechanism of cellular injury. Proc Nat' Acad Sci USA, 96, 6365-6370.

Garcia-Velasco, J. A. and Arici, A. (1999) Chemokines and human reproduction. Fertil Steril, $7 I_{\text {, }}$ 983-993.

Görg, A., Obermaier, C, Boguth, G., Harder, A., Scheibe, B., Wildgruber, R. and Weiss, W. (2000) The current state of two-dimensional electrophoresis with immobilized pH gradients. Electrophoresis, 21, 1037-1053.

Gradini, R., Realacci, M., Ginepri, A., Naso, G., Santangelo, C., Cela, O., Sale, P., Berardi, A., Petrangeli, E., Gallucci, M, et al. (1999) Nitric oxide synthases in normal and benign hyperplastic human prostate: immunohistochemistry and molecular biology. J Pathol, 189, 224-229.

Graven, K. K., Molvar, C., Roncarati, J. S., Klahn, B. D., Lowrey, S. and Farber, H. W. (2002) Identification of protein disulfide isomerase as an endothelial hypoxic stress protein. Am J Physiol Lung Cell Mol Physiol, 282, L.996-1003.

Haney, A. F., Muscato, J. J. and Weinberg, J. B. (1981) Peritoneal fluid cell populations in infertility patients. Fertil Steril, 35, 696-698.

Heukeshoven, J. and Dernick, R. (1988) Improved silver staining procedure for fast staining in PhastSystem Development Unit. I. Staining of sodium dodecyl sulfate gels. Electrophoresis, 9, 28-32.

Hill, J. A., Faris, H. M., Schiff, I. and Anderson, D. J. (1988) Characterization of leukocyte subpopulations in the peritoneal fluid of women with endometriosis. Fertil Steril, 50, 216-222.

Hogg, N. (1998) Free radicals in disease. Semin Reprod Endocrinol, 16, 24.1-248.

Hordijk, P. L., Verlaan, I., van Corven, E. J. and Moolenaar, W. H. (1994) Protein tyrosine phosphorylation induced by lysophosphatidic acid in Rat-1 fibroblasts. Evidence that phosphorylation of map kinase is mediated by the Gi-p2.1 ras pathway. J Biol Chem, 269, 645-651.

Hortelano, S., Genaro, A. M. and Bosca, L. (1993) Phorbol esters. induce nitric oxide synthase and increase arginine influx in cultured peritoneal macrophages. FEBS Lett, 320, 135-139.

Ischiropoulos, H. (1998) Biological tyrosine nitration: a pathophysiological function of nitric oxide and reactive oxygen species. Arch Biochem Biophys, 356, 1-11.

Kellie, S., Horvath, A. R. and Elmore, M. A. (1991) Cytoskeletal targets for oncogenic tyrosine kinases. $J$ Cell Sci, 99, 207-211.

Kimura, A., Koga, S., Kudoh, H. and litsuka, Y. (1985) Peritoneal mesothelial cell injury factors in rat cancerous ascites. Cancer Res, 45, 4330-4333.

Knepler, J. L., Jr., Taher, L. N., Gupta, M. P., Patterson, C., Pavalko, F, Ober, M. D. and Hart, C. M. (2001) Peroxynitrite causes endothelial cell monolayer barrier dysfunction. Am J Physiol Cell Physiol: 281, C1064-1075.

Koks, C. A., Groothuis, P. G., Dunselman, G. A., de Goeij, A. F. and Evers, J. L. (1999) Adhesion of shed menstrual tissue in an in vitro model using amnion and peritoneum: a light and electron microscopic study. Hum Reprod, 14, 816-822.

Koks, C. A., Demir Weusten, A. Y., Groothuis, P. C., Dunselman, G. A, de Goeij, A. F. and Evers, J. L. (2000a) Menstruum induces changes in mesothelial cell morphology. Gynecol Obstel. Invest, 50, 13-18.

Koks, C. A., Groothuis, P. G., Slaats, P., Dunselman, G. A., de Goeij, A. F. and Evers, J. L. (2000b) Matrix metalloproteinases and their tissue inhibitors in antegradely shed menstrum and peritoneal fluid. Fertil Steril, 73, 604-612. 
Levenson, R. M. and Blackshear, P. J. (1989) Insulin-stimulated protein tyrosine phosphorylation in intact cells evaluated by giant two-dimensional gẹl elẹctrophoreșiș. / Biol Chem, 264. 1998419993.

L.um, H. and Malik, A. B. (1996) Mechanisms of increased endothelial permeability. Can J Physiol Phormacol, 74, 787-800.

Martorana, A. M., Zheng, G. Crowe, T. C., O'Grady, R. L. and Lyons, J. G. (1998) Epithelial cells upregulate matrix metalloproteinases in cells within the same mammary carcinoma that have undergone an epithelial- mesenchymal transition. Cancer Res, 58, 4970-4979.

Pancholi, V. (200 i) Multifunctional a-enolase: its role in diseases. Cell Mol Life Sci, 58, 902-920.

Patlolla, A., Ogihara, K., Aoki, K., Zubkov, A., Bengten, E., Parent, A. D. and Zhang, 1. H. (1999) Hemolysate induces tyrosine phosphorylation and collagen-lattice compaction in cultured fibroblasts. Biochem Biophys Res Commun, 264, 100-107.

Pulyaeva, H., Bueno, J., Polette, M., Birembaut, P., Sato, H., Seiki, M. and Thompson, E. W. (1997) MT 1-MMP correlates with MMP-2 activation potential seen after epithelial to mesenchymal transition in human breast carcinoma cells. Clin Exp Metostasis, 15, 111-120.

Salamonsen, L. A. and Lathbury, L. J. (2000) Endometrial leukocytes and menstruation. Hum Reprod Update, 6, 16-27.

Telfer, J. F., Irvine, G. A., Kohnen, G., Campbell, S. and Cameron, I. T. (1997) Expression of endothelial and inducible nitric oxide synthase in non-pregnant and decidualized human endometrium. Mol Hum Reprod, 3, 69-75.

Timpson, P., Jones, G. E., Frame, M. C. and Brunton, V. G. (2001) Coordination of cell polarization and migration by the Rho family GTPases requires Src tyrosine kinase activity. Curr Biol, 11, 18361846.

Tschugguel, W., Schneeberger, C., Unfried, G., Brautigam, G., Stonek, F., Wieser, F., VytiskaBinstorfer, E., Czerwenka, K., Weninger, W., Kaider, $A_{r}$ et al (1999) Elevation of inducible nitric oxide synthase activity in human endometrium during menstruation. Biol Reprod, 60, 297-304.

Vepa, S., Scribner, W. M. and Natarajan, V. (1997) Activation of protein phosphorylation by oxidants in vascular endothelial celis: identification of tyrosine phosphorylation of caveolin. Free Radic Biol Med, 22, 25-35.

Viera, L., Ye, Y. Z., Estevez, A. G. and Beckman, J. S. (1999) Immunohistochemical methods to detect nitrotyrosine. Methods Enzymol, 301, 373=381.

Volliath, B., Cook, D., Megyesi, J., Findlay, J. M. and Ohkuma, H. (1998) Novel mechanism by which hemoglobin induces constriction of cerebral arteries. Eur I Pharmacol, 36 I, 31 ! -319.

Warn, R., Hanvey, P., Warn, A., Foley-Comer, A., Heldin, P., Versnel, M., Arakaki, N., Daikuhara, Y., Laurent, G. J., Herrick, S. Ev et al. (2001) HGF/SF induces mesothelial cell migration and proliferation by autocrine and paracrine pathways. Exp Cell Res, 267, 258-266.

Zhang, J., Nie, G., Jian, W., Woolley, D. E. and Salamonsen, L. A. (1998) Mast cell regulation of human endometrial matrix metalloproteinases: A mechanism underlying menstruation. Biol Reprod, 59, 693-703. 
$-[$ Chapter 8$]$

General discussion \& future perspectives 
Chapter 8 
The permanent, persistent presence of endometrium tissue at sites outside the uterus gives rise to endometriosis, which is presented in distinct forms and which lead's to various clinical manifestations. The transplantation theory is widely accepted to explain the pathogenesis of peritoneal endometriosis. Vital endometrium tissue present. in retrogradely shed menstrual effluent adheres to the peritoneum, followed by invasion, generation of blood supply and lesion formation.

In the early phases of this process the interaction of two components appear to play a key role: retrogradely shed menstrual endometrium, which is the result of menstrual cycle physiology, and mesothelial cells, which cover the surface of the peritoneal membrane as a single layer. The in vitro studies described in this thesis focus on this interaction.

The first study was to evaluate whether the menstrual effluent affects the mesothelial monolayer as a protective barrier. Then, it was investigated whether the alterations observed in mesothelial cells were associated with apoptosis or necrosis, or were the result of cellular remodeling. Subsequently, the process of remodeling was characterized as epithelial to mesenchymal transitions (EMT). To gain further insight in the EMT process, the changes in protein phosphorylation and expression that occur in mesothelial cells were monitored and analysed. Finally, it was attempted to elucidate the molecular features of the soluble factors in the menstrual effluent that may be involved in this EMT process.

The experiments that were designed to study this interaction used anterogradely instead of retrogradely shed menstrual effluent and mesothelial cell monolayers; prepared from human omentum, instead of mesothelium. it can be argued that anterogradely shed endometrium is different from retrogradely shed endometrium. More specifically, the environment of the peritoneal cavity, where the retrogradely shed endometrium arrives during menstruation, is different from the environment: on the proximal part of the vagina, where the menstrual cup (Keeper) collects the anterogradely shed menstrual effluent. Conditions such as $\mathrm{pH}_{\text {, tem- }}$ perature, enzymatic composition, MMPs and TIMPs, cellular constituents and their products create a microenvironment in which the endometrium tissue is affected in a different way. This may influence the way the endometrium interacts with mesothelial cells in the model system used. This is an obvious limitation of the study. However, retrogradely shed menstrual endometrium is difficult to collect. Similarly, the use of the peritoneal lining or mesothelial cells is rather difficult since collecting these cells at laparoscopy of laparotomy inflicts critical and irreversible damages to these cells. Therefore, these cells can not be used to study the interaction between endometrium and mesothelium. Mesothelial cell monolayers obtained from omentum were used to mimic the mesothelial lining (Bittinger et. al, 1997). Nevertheless, the initial steps in the development of the peritoneal lesions of endometriosis are preferably studied in an in vitro model.

The mesothelial lining of the peritoneum is a natural protective barrier. In our previous in vitro studies endometrium from proliferative, secretory and menstrual phases is shown to 
adhere to submesothelial structures where the mesothelial monolayer has been disrupted (Groothuis et al., 1998a, b; Koks et al., 1999). This has led to the assumption that an intact mesothelial layer prevents the adhesion of endometrium tissue from menstrual effluent.

Constituents of anterogradely shed menstrual effluent were cultured together with confluent mesothelial cell monolayers. Light and scanning electron microscopic studies indicated that soluble paracrine factors, present in menstrual effluent, induce morphological changes in mesothelial cells. During these changes cell-cell contacts dissociate, which results in retraction and shrinking of cells with exposure of the submesothelial matrix. This may imply that menstrual endometrium tissue is harmful to mesothelium, and hence creates adhesion sites for endometrium cells.

This morphologic effect appeared to be specific for the effluent and endometrium tissue from the menstrual phase. In contrast, endometrium obtained from proliferative and secretory phases was not able to induce morphological changes in mesothelial cells. Menstrual effluent and menstrual endometrium differs from endometrium obtained in the other phases of the menstrual cycle. This difference concerns in particular soluble paracrine factors such as matrix metalloproteinases, plasmin, cytokines, growth factors, that are abundant in the menstrual effluent and menstrual endometrium (Tabibzadeh, 1996; Koks et al., 2000). These factors conceivably influence the morphology of mesothelial cells. In other studies the interactions between proliferative and secretory phase endometrium tissue and mesothelial cells have been investigated (Zhang et al., 1993; Wild et al., 1994; Witz et al., 1999). No morphological changes in mesothelial cells were described.

The results of our in vitro studies are relevant for the pathogenesis of endometriosis. Menstrual effluent has the potential to induce morphological changes in mesothelial cells. Endometrial fragments in the menstrual effluent remain viable in the presence of peritoneal fluid in vitro for at least 72 hours, Therefore, it can be argued that retrogradely shed menstrual endometrium survives in the peritoneal cavity for a period of time sufficient to adhere to the peritoneum, at places where the submesothelial extracellular matrix is exposed.

Women with long and heavy menstrual bleeding or with a short menstrual cycle are more prone to develop endometriosis, in contrast to oral contraceptive users (Eskenażi and Warner, 1997). This can be explained by the amount of menstrual endometrium in the peritoneal cavity. The duration of interaction between menstrual effluent and mesothelial lining is another important determinant. It can be suggested that laparoscopies should not be performed during menstruation to prevent possible damage of the mesothelium by endometrium present in the abdominal cavity.

Prior to this work, it is not clear which mechanism is responsible for the mesothelial morphological changes induced by menstrual effluent. Several mechanisms of mesothelial damage and/or morphological changes of the mesothelium have been described.

(a) Cells, which generate soluble factors: Epidermal growth factor (EGF) induces morphological changes in mesothelial cells and is considered as a significant promoting factor in tumour cell adhesion to mesothelium in vitro and may therefore account for 
tumour recurrence in the peritoneum in vivo (van Rossen et al., 2001). The potential harmful effects of tumour cells and inflammatory cells on mesothelium have been extensively described (Niedbala et al., 1985; Akedo et al., 1986; Yashiro et al., 1996). Intraperitoneal injection of tumour cells, tumour ascites as well as conditioned media prepared from peritoneal fibroblasts, can induce morphological changes in mesothelial cells. The injury of the mesothelial cells has been considered to be a facilitating factor for the dissemination of tumour celis (Canis et al., 1998; Mutsaers, 2002).

(b) Mechanical damage to the peritoneum may facilitate the adhesion of cells to the mesothelium. It has been reported that metastasis and growth of peritoneal tumours increase after interferences such as port-site mechanical damage at laparoscopy.

(c) Chemical damage by using $\mathrm{CO}_{2}$ for insufflation during laparoscopy causes damage of the mesothelium and an increase in metastasis of tumour cells. (Bouvy et ol, 1996; Reymond et al., 1998). Chronic peritoneal dialysis causes fibrosis in mesothelial cells, due to the composition of the dialysis solution (Perfumo et al., 1996; Yang et al., 1997).

Morphological changes, such as cell-cell dissociation and cell shrinkage, induced in mesothelial cells by menstrual effluent resemble those in cells that undergo apoptosis or necrosis (Majno and Joris, 1995). To gain more insight into the underlying mechanism, we therefore investigated whether menstrual effluent induces the process of apoptosis or necrosis.

The results clearly show that menstrual effluent does not initiate apoptosis or necrosis in mesothelial cells, since only a small percentage of cells was apoptotic or necrotic (1-7\%), whereas the majority of cells showed remarkable morphological changes. Rather than apoptosis and necrosis, cellular remodeling is the mechanism underlying the observed morphological changes in mesothelial cells as is demonstrated by the reorganization of cytoskeletal proteins after culturing in menstrual effluent. A plausible underlying mechanism of cellular remodeling is epithelial to mesenchymal transitions (EMT).

The characterization of the cellular remodeling in mesothelial cells induced by menstrual effluent is an important step in understanding the interaction between these two components. As demonstrated in time-lapse video images recorded during a period of 20 hours, mesothelial cells go through a reversible active dynamic mesenchymal transformation process, which includes dissociation of cells and gain of a fibroblastic phenotype. A dynamic formation of lamellopodia and filapodia, which is associated with a conspicuous increase in cell motility, was shown to be a result of the activation of phosphorylation pathways, in particular tyrosine kinase signal transduction. This pathway is responsible for the EMT process in other types of epithelia (Savagner, 2001). The expression of transcription factor Snail and vimentin increased whereas the expression of E-cadherin decreased. The expression pattern of different cytokeratins was also altered. Therefore, it is concluded that the morphological changes observed in mesothelial cells fulfill the criteria for EMT. 
If the EMT process occurs in mesothelial cells during retrograde menstruation in vivo, it would mean that mesothelial cells have an active role in the ectopic adherence of endometrium cells. During EMT mesothelial cells alter the expression of proteinases and adhesion molecules, and the secretion of extracellular matrix components, e.g. fibronectin, and growth factors (Marshall et al., 1993; Rieppi et al., 1999). These alterations in mesothelial cells, together with the exposed submesothelial matrix, may facilitate the adhesion and growth of the menstrual endometrium cells.

The reversibility of the mesothelial EMT implies that the mesothelial cells may restore their normal epithelial-like morphology as soon as the menstrual effluent components in the peritoneal cavity are removed or inactivated. The mesothelial EMT induced by menstrual effluent is most likely a physiological phenomenon. Peritoneal dialysis solutions induce in vitro and ex vivo the process of EMT in mesothelial cells (Yanez-Mo et al., 2003; Yang et al., 2003). If this induction chronically continues the EMT in mesothelial cells may become irreversible and the cells acquire myofibroblastic characteristics (Yanez-Mo et al., 2003).

Besides its function as a protective barrier, the mesothelium has important physiological roles in fluid and cell transport, initiation and resolution of inflammation, tissue repair, lysis of fibrin deposits and facilitation of free movement of opposing organs and tissues. It is crucial in many pathological conditions, including peritonitis, mesothelioma, peritoneal fibrosis, adhesions and metastasis. As mentioned before the mesothelial lining is actively involved in the development of endometriosis. The identification of mesothelial proteins and the determination of changes in protein expression and phoshorylation may contribute to the understanding of these pathological processes. Therefore, we attempted to obtain proteome information on mesothelial cells and identified 74 mesothelial proteins.

The EMT process is a manifestation of epithelial plasticity during embryo and organ morphogenesis, wound healing and tumour progression. This process has been studied in transforming epithelia (Zondag et al., 2000). According to these studies signal transduction pathways involving (Src) tyrosine kinases, Rho-, Ras-, Wht-proteins are not only coupled to transcription factors, like Snail and Tiam-1, but also to cytoskeletal proteins, like actin and cytokeratin, and adhesion molecules, like E-cadherins, integrins, desmosome proteins. We hypothesized that shed menstrual effluent induces EMT in mesothelial cells by activating signaling cascades that lead to changes in the expression and phosphorylation of proteins involved in cytoskeletal organization. The functional changes during the mesothelial EMT are not known, but similar mechanisms as occur in tumour cells are expected. Therefore, we attempted to characterize the functional changes in mesothelial EMT by morphological and molecular assays, i.e. light microscopy, 2D-PAGE and mass spectrometiry.

We have demonstrated that during mesothelial EMT the expression patterns of 35 proteins involved in organization of the cytoskeleton, signal transduction, regulation of the redox state and metabolic balance, were changed. In particular, a reorganization of actin 
filaments and microtubules and a shift in the filament system from cytokeratins ? and 19 to vimentin was observed. This type of reorganization and the cytokeratin-vimentin shift have also been reported for the EMT in other types of epithelia (Savagner, 2001; PerezPomares and Munoz-Chapuli, 2002). We have also shown that annexin-1 is phosphorylated and newly expressed during this process, which implies that this protein may be an upstream activator of the Sic tyrosine kinase signaling pathway. It is important to realize, however, that due to the limitations of the 2D-PAGE technique not all relevant proteins can be detected.

Menstrual endometrium does not only contain fragments of endometrial glands and stroma, but also many leukocytes, such as mast cells, eosinophils, neutrophils and macrophages. Due to this hyperinflammatory state as well as the hypoxia during tissue: shedding, menstrual effluent is enriched by nitric oxide, growth factors, chemokines, cytokines, and proteinases which may facilitate attachment of endometrial fragments and angiogenesis by inducing the EMT process in mesothelial cells (Chwalisz and Garfield, 2000; Brenner et al., 2002; Salamonsen, 2003). This hypothesis is based on the observations made in mesothelial cells treated with various stimuli, i.e. peritoneal dialysis solution, EGF, HGF/SF, TNF- $\alpha$ and TGF- $\beta$ (van Rossen et al., 2001; Warn et al., 2001; Zhu et al., 2002; Yanez-Mo et al., 2003; Yang et al., 2003). After culturing in the presence of these stimuli, mesothelial cells displayed changes similar to mesothelial EMT induced by menstrual effluent.

To improve our understanding on the mechanisms responsible for mesothelial EMT: induced by menstrual effluent, we attempted to characterize the effector molecules in this effluent. The results demonstrated that nitric oxide reaction products as well as matrix metalloproteinases were not involved. Still, it was passible to determine some features of the potential inducers in menstrual effluent. These molecules are proteins that have a molecular weight above $50 \mathrm{kD}$ and are presumably part of multimers or multicomplex. structures.

Using 2D-PACE and mass spectrometry $\alpha$-enolase and haemoglobin were identified as potential candidates. $\alpha$-Enolase is an interesting protein in regard to mesothelial EMT mainly because of its two features; it is a substrate for Src tyrosine kinases; and a receptor for plasminogen (Atfi et al., 1994; Pancholi, 2001). Previous studies have reported that the plasmin system regulates cytoskeleton reorganization, cell-matrix interactions and cell migration (Degryse et al., 1999; Chapman and Wei, 2001). Moreover, it has been shown that mesothelial cells secrete in vitro PPA, PAl- 1 and PAl-2 (van Hinsbergh et al., 1990) and menstrual effluent is a rich source for plasmin/plasminogen (Tabibzadeh, 1996). On the basis of these reports, it is feasible that these serine proteases are involved in the mesothelial EMT, and thus $\alpha$-enolase is considered to be a candidate effector in menstrual effluent.

Modified haemoglobin has been reported to change the integrity of the cell-cell junctions and the actin cytoskeleton in endothelial cells (Baldwin, 1999). It is possible that haemoglobin in menstrual effluent derived from the hemolized enythrocytes is modified 
by many oxidation products in menstrual effluent and is capable to induce the EMT process in mesothelial cells.

It can not be excluded, however, that other proteins are undetectable due to masking by the high abundance of albumin or other serum proteins, which are similar in size, charge and adhesive nature.

In this thesis several molecules have been identified, which are possibly involved in mesothelial EMT induced by anterogradely shed menstrual endometrium. How these molecules function, interact and determine the fate of the EMT in mesothelial cells is not yet thoroughly defined. It might be useful to extrapolate the data obtained from cancer studies, wherein the process of EMT is characterized more in detail, to EMT in mesothelial cells. Finally, on the basis of literature reports and studies described in this thesis, a summary of key molecules involved in EMT is presented in Figure 1 (see appendix).

\section{Future perspectives}

An in vitro model was used to study the events that may occur during the early pathogenesis of endometriosis, in particular the EMT process in mesothelial cells induced by anterogradely shed menstrual effluent. These alterations are considered to facilitate the subsequent: adhesion and invasion of endometrial cells on the peritoneal surfaces. To confirm these thoughts, an in vivo model has to be established, in which it is demonistrated that EMT in mesothelial cells occurs also in in vivo conditions.

Prior to in vivo studies, a 3 -dimensional culture model, in which stromal and endothelial cells are embedded in an extracellular matrix (Bittinger et al., 1997), can be useful to collect more information on the mesothelial EMT. Another point concerning the in vitro culture model is the use of mesothelial cells originating from human omentum. It is interesting to verify whether the observations with these cell types are similar to those with mesothelial cells isolated from human peritoneum.

In our studies the effect of menstrual endometrium on mesothelial cells has been tested for short periods of time. Considering that retrograde menstruation is an iterative event by which mesothelial cells are intermittently exposed to the contents of menstrual effluent, it is possible that the mesothelial EMT become irreversible. It is therefore interesting to culture mesothelial cells in menstrual effluent for a longer period of time.

It is also interesting to compare the anterogradely shed menstrual effluent from women with and without clinical endometriosis with regard to EMT in mesothelial cells. It is a challenge to mimic the physiological situation of retrogradely shed menstrual effluent influencing mesothelial cells.

The proteome data for mesothelial cells could be completed by using narrow range $\mathrm{pH}$ gradients in the first dimension. Alterinatively, the mesothelial proteome and changes asso- 
ciated with EMT could be analysed with protein (chip) arrays, if these are available. This may allow to identify proteins which are specific for normal mesothelial cells. This knowledge can be used to develop markers to distinguish normal mesothelial cells from malignant cells, such as ovarian carcinoma, mesothelioma or other metastasizing tumours.

As the potential candidates for EMT induction we identified $\alpha$-enolase and haemoglobin. These results have to be verified in experimental settings in which specific antibodies are used to inhibit the potential effect of anterogradely shed menstrual effluent. Furthermore, many growth factors (EGF, TGF- $\beta$, IGF, HCS/SF, etc.) and extracellular matrix molecules (collagen, fibronectin, hyaluronan) have been implicated in the EMT process for several cell types. To demonstrate whether these molecules are EMT-inducers in mesothelial cells, studies with specific antibodies or inhibitors have to be performed.

\section{References}

Akedo, H., Shinkai, K. Mukai, M., Mori, Y, Tateishi, R., Tanaka, K., Yamamoto, R. and Morishita, T. (1986) interaction of rat ascites hepatoma cells with cultured mesothelial cell layers: a model for tumour invasion. Cancer Res, 46, 2416-2422.

Atfi, A., Drobetsky, E., Boissonneault, M., Chapdelaine, A. and Chevalier, S. (1994) Transtoming growth factor $\beta$ down-regulates Src family protein tyrosine kinase signaling pathways. $J$ Biol Chem. 269, 30688-30693.

Baldwin, A. L. (1999) Modified hemoglobins produce venular interendothelial gaps and albumin leakage in the rat mesentery. Am J Physiol, 277, H650-659.

Bittinger, F., Brochhausen, C., Skarke, C., Kohler, H. and Kirkpatrick, C. J. (1997) Reconstruction of peritoneal-like structure in three-dimensional collagen gel matrix culture. Exp Cell Res, 236, 155-160.

Boumy, N. D., Marquet, R. L., Jeekel, H. and Bonjer, H. J. (1996) Impact of gas(less) laparoscopy and laparotomy on peritoneal tumour growth and abdominal wall metastases. Ann Surg, 224, 694-700.

Brenner; R. M., Nayak, N. R., Slayden, O. D., Critchley, H. O. and Kelly, R. W. (2002) Premenstrual and menstrual changes in the macaque and human endometrium: relevance to endometriosis. Ann NYAcad Sci, 955, 60-74.

Canis, M., Botchorishvili, R., Wattiez, A., Mage, G., Pouly, J. L. and Bruhat, M. A. (1998) Tumour growth and dissemination after laparotomy and $\mathrm{CO}_{2}$ pneumoperitoneum: a rat ovarian cancer model. Obstet Cynecol, 92, 104-108.

Chapman, H. A. and Wei, Y. (2001) Protease crosstalk with integrins: the urokinase receptor paradigm. Thromb Hoemost; 86, 124-129.

Chwalisz, K. and Garfield, R. E. (2000) Role of nitric oxide in implantation and menstruation. Hum Reprod, 15 Suppl 3, 96-111.

Degryse, B., Resnati, M., Rabbari, S. A., Villa, A., Fazioli, F. and Blasi, F. (1999) Src-dependence and pertussis-toxin sensitivity of urokinase receptor- dependent chemotaxis and cytoskeleton reorganization in rat smooth muscle cells. Blood, 94, 549-662.

Eskenazi, B. and Warner, M. L. (1997) Epidemiology of endometriosis. Obstet Gynecol Clin North Am, 24, 235-258.

Groothuis, P. G., Koks, C. A., de Goeij, A. F., Dunselman, G. A., Arends, J. W. and Evers, 1. L. (1998a) Adhesion of human endometrium to the epithelial lining and extracellular matrix of amnion in vitro: an electron microscopic study. Hum Reprod, 13, 2275-2281.

Groothuis, P. G., Koks, C. A., de Goeij, A. F., Dunselman, G. A., Arends, J. W. and Evers, J. L. (1998b) Adhesion of human endometrial fragments to peritoneum in vitro. Fertil Steril, 71, 1119-1124. 
Koks, C. A., Groothuis, P. G., Dunselmann, G. A., de Cioeij, A. F. and Evers, J. L. (1999) Adhesion of shed menstrual tissue in an in vitro model using amnion and peritoneum: a light and electron microscopic study. Hum Reprod, 14, 816-822.

Koks, C. A., Groothuis, P. G., Slaats, P., Dunselman, G. A., de Goeij, A. F. and Evers, J. L. (2000) Matrix metalloproteinases and their tissue inhibitors in antegradely shed menstruum and peritoneal fluid. Fertil Steril, 73, 604-612.

Majno, G. and Joris, I. (1995) Apoptosis, oncosis, and necrosis. An overview of cell death. Am J Pathol, 146, 3-15.

Marshall, B. C., Santana, A., Xu, Q. P., Petersen, M. J., Campbell, E. J., Hoidal, J. R. and Welgus, H. G. (1993) Metalloproteinases and tissue inhibitor of metalloproteinases in mesothelial cells. Cellular differentiation influences expression. J Clin Invest, 91, 1792-1799.

Mutsaers, S. E. (2002) Mesothelial cells: their structure, function and role in serusal repair. Respirology, 7, 171-191.

Niedbala, M. J., Crickard, K. and Bernacki, R. J. (1985) Interactions of human ovarian tumour cells with human mesothelial cells grown on extracellular matrix. An in vitro model system for studying tumour cell adhesion and invasion. Exp Cell Res, 160, 499-513.

Pancholi, V. (2001) Multifunctional $\alpha$-enolase: its role in diseases. Cell Mol Life Sci, 58, 902-920.

Perez-Pomares, J. M. and Munoz-Chapuli, R. (2002) Epithelial-mesenchymal transitions: a mesodermal cell strategy for evolutive innovation in Metazoans. Anot Rec, 268, 343-351.

Perfumo, F., Altieri, P., Degl'Innocenti, M. L., Ghiggeri, G. M., Caridi, G., Trivelli, A. and Gusmano, R. (1996) Effects of peritoneal effluents on mesothelial cells in culture: cell proliferation and extracellulai matrix regulation. Nephrol Dial Transplant, 11, 1803-1809.

Reymond, M. A., Schneider, C., Kastl, S., Hohenberger, W. and Kockerling, F. (1998) The pathogenesis of port-site recurrences. J Gastrointest Surg, 2, 406-414

Rieppi, M., Vergani, V., Gatto, C., Zanetta, G., Allavena, P., Taraboletti, G. and Giavazzi, R. (1999) Mesothelial cells induce the motility of human ovarian carcinoma cells. Int J Cancer, 80, 303-307.

Salamonsen, L. A. (2003) Tissue injury and repair in the female human reproductive tract. Reproduction, 125, 301-311.

Savagner, P. (2001) Leaving the neighborhood: molecular mechanisms involved during epithelialmesenchymal transition. Bioessays, 23, 912-923.

Tabibzadeh, S. (1996) The signals and molecular pathways involvedi in human menstruation, a unique process of tissue destruction and remodeling. Mol Hum Reprod, 2, 77-92.

van Hinsbergh, V. W. Kooistra, T., Scheffer, M. A., Hajo van Bockel, J. and van Muijen, G. N. (1990) Characterization and fibrinolytic properties of human omental tissue mesothelial cells. Comparison with endothelial cells. Blood, 75, 1490-1497.

van Rossen, M. E., Hofland, L. J., van den Tol, M. P., van Koetsveld, P. M., Jeekel, J., Marquet, R. L. and van Eijck, C. H. (2001) Effect of inflammatory cytokines and growth factors on tumour cell adhesion to the peritoneum. I Pathol, 193, 530-537.

Warn, R., Harvey, P., Warn, A., Foley-Comer, A., Heldin, P., Versnel, M., Arakaki, N., Daikuhara, Y., Laurent, G. J., Herrick, S. E, et al. (2001) HGF/SF induces mesothelial cell migration and proliferation by autocrine and paracrine pathways. Exp Cell Res, 267, 258-266

Wild, R. A., Zhang, R. J. and Medders, D. (1994) Whole endometrial fragments form characteristics of in vivo endometriosis in a mesothelial cell co-culture system: an in vitro model for the study of the histogenesis of endometriosis. I Soc Gynecol Investig, 1, 65-68.

Witz, C. A. Monotoya-Rodriguez, I. A. and Schenken, R. S. (1999) Whole explants of peritoneum and endometrium: a novel model of the early endometriosis lesion. Fertil Steril, 71, 56-60.

Yanez-Mo, M., Lara-Pezzi, E., Selgas, R., Ramirez-Huesca, M., Dominguez-Jimenez, C., JimenezHeffernan, 1. A., Aguilera, A., Sanchez-Tomero, J. A., Bajo, M. A., Alvarez, V, et al. (2003) Peritoneal dialysis and epithelial-to-mesenchymal transition of mesothelial cells. $N$ Engl J Med, 348, 403-413. 
Yang, A. H., Chen, J. Y., Lin, Y. P., Huang, T. P. and Wu, C. W. (1997) Peritoneal dialysis solution induces apoptosis of mesothelial cells. Kidney Int, 51, 1280-1288.

Yang, A. H., Chen, J. Y. and Lin, J. K. (2003) Myofibroblastic conversion of mesothelial cells. Kidney Int, 63, 1530-1539.

Yashiro, M., Chung, Y. S., Inoue, T., Nishimura, S., Matsuoka, T., Fujihara, T. and Sowa, M. (1996) Hepatocyte growth factor (HGF) produced by peritoneal fibroblasts may affect mesothelial cell morphology and promote peritoneal dissemination. Int I Concer, 67, 289-293.

Zhang, R. J., Wild, R. A. and Ojago, J. M. (1993) Effect of tumour necrosis factor- $\alpha$ on adhesion of human endometrial stromal cells to peritoneal mesothelial cells: an in vitro system. Fertil Steril, 59, $1196-1201$

Zhu, Z., Yao, J., Wang, F. and Xu, Q. (2002) TNF- $\alpha$ and the phenotypic transformation of human peritoneal mesothelial cell. Chin Med J, 115, 513-517.

Zondag, G. C., Evers, E. E., ten Klooster, J. P., Janssen, L., van der Kammen, R. A. and Collard, J. G. (2000) Oncogenic Ras downregulates Rac activity, which leads to increased Rho activity and epithelial-mesenchymal transition. J Cell Biol, 149, 775-782. 


\section{Summary ]}

Endometriosis is the oestrogen-dependent growth of endometrial cells at sites outside the. uterus. This disease is presented in distinct forms, which leads to various clinical manifestations. Although the pathogenesis of endometriosis is still prone to debate, the transplantation theory is widely accepted. According to this theory viable endometrium tissue, which is regurgitated during menstruation into the abdominal cavity through the Fallopian tubes, adheres to the peritoneal surfaces, generates its own blood supply and grows into an active lesion of endometrium-like tissue. Previous adhesion studies using peritoneum and endometrium from different phases of the menstrual cycle have shown that endometrial fragments adhere where the mesothelial layer of the peritoneum is damaged. Based on these findings, an intact mesothelial lining is suggested to be a protective barrier against the adhesion of endometrial fragments obtained from different phases of menstrual cyclus. We, therefore, hypothesized that shed menstrual endometrium is capable to disrupt the intact mesothelial lining facilitating the adhesion of endometrium fragments orto the peritoneum surface and hence the development of endometriosis. The studies described in this thesis attempt to illuminate this initial interaction by exploring the effects of shed menstrual endometrium on the cells of the mesothelial lining at the cellular and subcellular level.

Retrogradely shed menstrual effluent is difficult to obtain. Therefore, anterogradely shed menstrual effluent collected with a vaginal cup (Keeper) was used as a source of menstrual endometrium. Monolayers of mesothelial cells recovered from human omentum were used to mimic the mesothelial lining of the peritoneum.

A literature review is presented in chapter $\mathbf{1}$ and the aims of the study in chapter 2.

In chapter 3, the potential detrimental effect of the menstrual effluent components on the mesothelial cell monolayer were investigated with light and scanning electron microscopy. The results of this study pointed out that the paracrine factors present in the menstrual effluent induced changes in mesothelial cell morphology, including retraction and shrinking of the covering layer with exposure of the underlying structures of basement membrane and extracellular matrix. This effect was unique for menstrual effluent since similar experiments with endometrium obtained from secretory and proliferative phases did not cause morphological changes in mesothelial cells. These findings led to the conclusion that menstrual endometrium is able to create adhesion sites by local disruption of the mesothelial layer.

The alterations induced by menstrual effluent as observed in mesathelial cells closely resemble morphological changes during cell death, i.e. apoptosis or necrosis, or during celIular remodeling. In chapter $\mathbf{4}$, it was investigated whether these processes were respon= sible for the morphological changes in mesothelial cells. Flow cytometric analysis with markers for apoptosis or necrosis, such as the M30 CytoDeath antibody and annexin V 
combined with propidium iodide, revealed that after overnight incubation with menstrual effluent only 1 to $7 \%$ of the mesothelial cells were apoptotic or necrotic. These numbers were within the physiological range. In contrast, the morphology of almost all mesothelial cells was affected after incubation with menstrual effluent. Immunostaining for cytokeratins, vimentin and fibrillar actin showed that the profoundly altered morphology of mesothelial cells was related to extensive reorganization of cytoskeletal elements. Therefore, we concluded that cellular remodeling, rather than apoptosis or necrosis is responsible for the observed alterations in mesothelial cell morphology.

One of the forms of cellular remodeling is epithelial to mesenchymal transitions (EMT). Therefore, in chapter $\mathbf{5}$ this process was studied at the morphological and molecular level in mesothelial cells. By using time-lapse video microscopy we observed that when exposed to menstrual effluent the mesothelial cells underwent a dynamic process, including dissociation of the cellular contacts, increase in cell motility and formation of cellular extensions. Within 24 hours the mesothelial cells obtained a spindle-like or a round morphology. When the culture medium was replaced with the normal culture medium, the typical mesothelial morphology was recovered within 4 days. Based on these observations, we concluded that menstrual effluent causes reversible changes in the morphology of the mesothelium and does not necessarily cause permanent damage to the peritoneal lining. Further evidence was provided that the cellular remodeling in response to shed menstrual effluent is EMT. Inhibition studies demonstrated that the altered morphology was a result of an energy-dependent transition process, which involved (Src) tyrosine kinase signaling. In addition, the expression of vimentin and the transcription factor Snail were up-regulated, whereas the expiession of E-cadherin was dramatically reduced and the expression of subtypes of cytokeratins was changed.

In chapter 6 the functional changes in cellular proteins that determined the EMT in mesothelial cells were assessed. Menstrual factors induced specific changes in the phos phorylation and expression status of regulatory, metabolic and structural proteins relevant to the complex process of EMT. These data allowed a specification of the signaling pathways that contribute to this process. For example, differential phosphorylation of annexin-1, which is a substrate for tyrosine kinase activity associated with growth factor receptors, indicated that (Src) tyrosine kinase pathways are involved in the transduction of EMT-signal in mesothelial cells. Moreaver, differential expression of proteins related to the Rho family of small G proteins indicated that menstrual effluent transmitted the EMT inducing message via Ras, Rho, and MAPK signaling pathways as well. Differential phosphorylation of tropomyosin- $\alpha$ and differential expression of actin and tubulin binding proteins, as well as cytokeratin and vimentin filaments indicate that the signal terminates in the reorganization of cytoskeleton proteins, particularly actin filaments and subsequently in the phenotypic changes of mesothelial cells. In this chapter additional information on the mesothelial proteome was also provided.

In order to better understand the process of EMT in mesothelial cells the inducing factor(s) in the menstrual effluent should be characterized and identified if possible. In chap- 
ter 7, strategies are described to purify and characterize these factors. Incubation studies with specific agents that inhibit matrix metalloproteinases, the use of RT-PCR to evaluate iNOS expression and immunostaining for nitrotyrosine did not provide any evidence that these molecules are involved in the EMT process in mesothelial cells. Furthermore, size fractionation techniques revealed that the soluble factors that were assumed to be responsible for the EMT process were proteins with a molecular weight larger than $50 \mathrm{kD}$. Further analysis by using proteomics yielded the identities of two proteins, i.e. $\alpha$-enolase and haemoglobin. Since $\alpha$-enolase is a plasminogen receptor and a substrate for (Sic) tyrosine kinase proteins, and haemoglobin can change actin cytoskeleton through tyrosine kinase signaling, these two proteins are possible candidates for the induction of EMT in mesothelial cells.

in chapter $\mathbf{8}$ the results and conclusions of these studies are discussed and several future perspectives are outlined.

Taken together, the results of the present study contribute to refining the molecular mechanisms that occur at the interface of shed menstrual endometrium and mesothelial cells. The menstrual effluent is capable to induce a transition process in mesothelial cells through which the cells change their phenotype from an epithelial to a fibroblast-type. Several signal transduction pathways, in particular those which involve tyrosine kinases are taking part in this transition process. To date unknown soluble molecules in menstrual effluent are potential candidates for the induction of the signal in mesothelial cells. 


\section{Samenvatting}

Endometriose is de oestrogeen-afhankelijke groei van endometrium op plaatsen buiten de uterus. Deze ziekte heeft verschillende uitingsvormen, die leiden tot verscheidene klinische manifestaties. Hoewel er nog steeds discussie is over de pathogenese van endometriose, is de transplantatietheorie wijdverbreid geaccepteerd. Volgens deze theorie hecht vitaal endometrium, dat tijdens de menstruatie via de eileiders in de buikholte terecht is gekomen, aan het peritoneum, genereert een eigen bloedvoorziening en groeit uit tot een endometriose laesie. Eerdere studies over hechting van endometrium aan perltoneum, waarin gebruik gemaakt werd van endometrium dat verkregen werd uit de verschillende fasen van de menstruele cyclus, hebben aangetoond dat endometriumfragmenten daar aanhechten waar het mesotheel van het peritoneum beschadigd is. Gebaseerd op deze bevindingen wordt verondersteld dat een intacte mesotheellaag een beschermende barrière vormt tegen de hechting van endometriumfragmenten tijdens de menstruatie fase van de cyclus en mogelijk ook in de overige fasen van de cyclus. Onze hypothese luidt dan ook, dat endometrium dat door retrograde menstruatie in de buikholte terecht is gekomen, in staat is de intacte mesotheellaag te beschadigen, waardoor endometriumfragmenten aan de onder het mesotheel gelegen extracellulaire matrix kunnen hechten, waarna endometriose kan ontstaan.

De dialoog tussen endometrium en mesotheel vormt het onderwerp van de studies zoals beschreven in dit proefschrift. De effecten van menstrueel endometrium op de mesotheellaag werden onderzocht op cellulair en subcellulair riveau.

Retrograad afgescheiden menstruum is moeilijk te verkrijgen. Daarom is antegraad afgescheiden menstruum verzameld met behulp van een vaginale cup (Keeper). Monolagen van mesotheelcellen verkregen uit menselijk omentum zijn gebruikt om de mesotheellaag van het peritoneum na te bootsen.

In hoofdstuk 1 wordt een overzicht gepresenteerd van de relevante literatuur, in hoofdstuk 2 de doelstellingen van de studie.

In hoofdstuk $\mathbf{3}$ wordt het potentieel schadelijke effect van componenten van het menstruum op de mesotheellaag beschreven met behulp van lichtmicroscopie en scanning electronenmicroscopie. De resultaten van deze studie wijzen uit dat paracriene factoren in het menstruum veranderingen induceren in de morfologie van de mesotheelcel. De mesotheelcellen veranderen van vorm, er treedt retractie en krimp op. Dit leidt tot blootstelling van de onderliggende structuren van de basaalmembraan en de extracellulaire matrix. Dit effect is uniek voor menstruum, omdat soortgelijke experimenten met endometrium verkregen uit de secretoire en proliferatieve fasen geen morfologische veranderingen in de mesotheelcelien veroorzaken. Deze bevindingen leiden tot de conclusie dat menstrueel endometrium in staat is hechtplaatsen te creëren door lokale: beschadiging van de mesotheellaag. 
De door menstruum geïnduceerde veranderingen die geobserveerd werden in mesotheelcellen lijken sterk op de morfologische veranderingen die optreden tijdens apoptose of necrose, of bij het proces van cellulaire hermodellering (cellular remodeling). In hoofdstuk 4 wordt onderzoek beschreven naar de vraag of deze drie processen verantwoordelijk zijn voor de morfologische veranderingen in de mesotheelcellen. Flow-cytometrische analyses met markers voor apoptose en necrose, zoals het M30 CytoDeath antilichaam en annexine $V$ in combinatie met propidium jodide, wezen uit dat na incubatie met menstruum slechts 1 tot $7 \%$ van de mesotheelcellen apoptotisch of necrotisch waren geworden. Deze percentages liggen binnen de fysiologische grenzen. Daarentegen werd de morfologie van bijna alle mesotheelcellen beinvloed door incubatie met menstruum. Immuunkleuringen voor cytokeratine, vimentine en fibrillair actine toonden aan dat de veranderde morfologie van mesotheelcellen gerelateerd is aan een extensieve reorganisatie van elementen van het cytoskelet. Daarom concluderen wij dat niet de apoptose of necrose, maar de cellulaire hermodellering verantwoordelijk is voor de waargenomen veranderingen in de morfologie van de mesotheelcellen.

'Epitheliale-mesenchymale transitie' (EMT) is een van de vormen van cellulaire hermodellering, waarbij het fenotype van de cel verandert van een epitheliale naar een mesenchymale vorm. In hoofdstuk $\mathbf{5}$ wordt dit proces in de mesotheelcellen beschreven op morfologisch en moleculair niveau. Met behulp van time-lapse video microscopie observeerden we dat mesotheelcellen, indien blootgesteld aan menstruum, een dynamische verandering ondergingen, namelijk een dissociatie van de cellulaire contacten, een toename in beweeglijkheid van de cellen en formatie van de cellulaire uitlopers. Binnen. 24 uur kregen de mesotheelcellen een spoelvormige of een ronde morfologie. Wanneer het door menstruum geconditioneerde medium vervangen werd door het normale kweekmedium herstelde de typische mesotheelmorfologie zich binnen 4 dagen. Gebaseerd op deze observaties concludeerden we dat menstruum reversibele veranderingen veroorzaakt in de morfalogie van het mesotheel en geen permanente schade toebrengt aan de mesotheellaag op het peritoneum. Bovendien werd bewezen dat de cellulaire hermodellering die optreedt in reactie op contact met het menstruum een epitheliale-mesenchymale transitie is. Remmingstudies lieten zien dat de veranderde morfologie het resultaat is van een energieafhankelijk transitieproces; waarbij (Src) tyrosine-kinase signalering betrokken is. Bovendien vond een toename plats van de expressie, van vimentine en van de transcriptie factor Snail, terwijl de expressie van E-cadherine drastisch gereduceerd werd, en de expressie van subtypen van cytokeratinen werd veranderd.

in hoofdstuk 6 worden de functionele veranderingen in cellulaire eiwitten die de epitheliale-mesenchymale omzetting in mesotheelcellen bewerkstelligen beschreven. Factoren in het menstruum induceren specifieke veranderingen in de mate van phosphorylering en expressie van regulerende, metabole en structurele eiwitten die relevant zijn in het complexe proces van epitheliale-mesenchymale omzettingen. Deze gegevens maakten een specificatie mogelijk van de signaalroutes die bijdragen aan dit proces. 
Bijvoorbeeld: een veranderde phosphorylering van annexine 1, dat een substraat is voor de tyrosine-kinase activiteit die geassocieerd is met receptoren voor groeifactoren, wijst erop dat (Src) tyrosine-kinase routes betrokken zijn bij de transductie van het EMT-signaal in mesotheelcellen. Bovendien wijst een veranderde expressie van eiwitten die gerelateerd zijn aan de Rho-familie van kleine G-eiwitten erop, dat menstruum de boodschap die de EMT induceert doorgeeft via Ras, Rho, en MAPK signaalroutes. Veranderde phosphorylering van tropomyosine- $\alpha$ en veranderde expressie van zowel actine en tubuline bindende eiwitten als cytokeratine en vimentine filamenten wijzen erop dat het sig. naal leidt tot de reorganisatie van cytoskeleteiwitten, in het bijzonder actinefilamenten, en vervolgens resulteert in de fenotypische veranderingen van de mesotheelcellen. In dit hoofdstuk wordt bovendien aanvullende informatie gegeven over het proteoom van het mesotheel.

Om het proces van EMT in mesotheelcellen beter te begrijpen moeten de inducerende factoren in het menstruum gekarakteriseerd worden en zo mogelijk worden geidentificeerd. In hoofdstuk 7 worden er strategieën beschreven om deze factoren te specificeren en te identificeren. Remming van matrixmetalloproteinasen, iNOS expressie geëvalueerd met behulp van RT-PCR, en immunohistochemie voor nitrotyrosine in mesotheelcellen leverden geen bewijs dat deze moleculen betrokken waren in het EMT-proces. Het. fractioneren van de oplosbare factoren, die verondersteld worden verantwoordelijk te zijn voor het EMT-proces, toonde aan dat dit eiwitten zijn met een moleculair gewicht groter dan $50 \mathrm{kD}$. Verdere analyse van deze eiwitten met behulp van proteomics leidde tot identificatie van twee eiwitten, $\alpha$-enolase en haemoglobine. Omdat $\alpha$-enolase een plasminogeenreceptor is, en tevens een substraat is voor (Src) tyrosine-kinase eiwitten, en omdat haemoglobine het actinecytoskelet kan veranderen door tyrosine-kinase signalering, zijn deze twee eiwitten mogelijke kandidaten voor de inductie van EMT in mesotheelcellen.

In hoofdstuk $\mathbf{8}$ worden de resultaten van het onderzoek gerelateeid aan bevindingen uit de literatuur en een breder perspectief geplaatst. Tevens wordt een aanzet gegeven tot verder onderzoek.

Samenvattend dragen de resultaten van deze studie bij aan de verfijning van kennis over de moleculaire mechanismen die zich afspelen in de interactie tussen menstruum en mesotheelcellen. Het menstruum is in staat een proces van verandering in mesotheelcellen te induceren, waardoor de cellen hun fenotype van een epitheel- in een fibroblast-type veranderen. Verscheidene signaal-transductie routes, in het bijzonder die van tyrosine-kinase, participeren in dit proces van verandering. Tot nu toe onbekende factoren in menstruum zijn potentiële kandidaten voor de inductie van het signaal in mesotheelcellen. 


\section{[ özet ]}

Endometriyozis, rahim iç tabakasını (endometriyum) oluşturan hücrelerin rahim iç yüzeyi dıșında bir yere yerleşerek östrojene bağımlı olarak büyüme ve gelișmeleri olarak tanımlanabilir. Bu hastalık kendisini değișik klinik belirtilere neden olan farklı formlarda gösterir. Endometriyozisin patogenezi halen daha tartıșmaya açik olsa da, transplantasyon teorisi en çok kabul gören yaklașımdır. Adet döngüsünün (menstruasyon) fizyolojik seyrinde rahim iç tabakası kalınlaşır ve belli bir süre sonra kanamayla vajinadan dışarı atılir. Bu sureç esnasında yumurtalık tüpleri vasıtasıyla bir miktar adet kanı karın boşlug̃una ulaşır. Transplantasyon teorisine göre halen canllığını koruyan bu rahim iç tabaka dokusu karın boşlug̃unu çevreleyen periton membranına yapıșı (adhezyon), ve kendi kan dolaşımını oluştururarak rahim iç tabakası benzeri aktif bir dokuya dönüșür. Periton membranı ve adet döngüsünün tüm fazlarından elde edilmiş rahim iç tabaka dokusu kullanılarak yapılan çalıșmalarda, bu doku parçalarının periton membran yüzeyini örten epitel hücre bariyerindeki (mezotel) hasarlı bölgelere yapıștıkları gözlenmiștir. Bu bulgulara dayanarak devamlıı̆̊ı bozulmamış bir mezotel yüzeyinin, adet kanındaki mevcut endometriyum parçalarının tutunmasına engel oldug̃u öne sürülmüștür. Bundan dolayı adet kanaması sırasında karın boşluğuna dökülen endometriyum dokusunun (menstrüel endometriyum) sağlam mezotel yüzeyinde hasara yol açabilecek kapasitede olduğu ve böylelikle bu dokunun periton yüzeyine yapıșarak endometriyozis gelișimini kolaylaștırdı̊̆ı hipotezini ortayya attık. Bu tezde rapor edilen çalışmalar hücre ve hücrealtı seviyesinde vuku bulan menstrüel endometriyum ile mezotel hücrelerinin ilk etkileșimini aydınlatmaya çalıșmaktadır.

Karın boşlug̃una dökülen adet kanını elde etmenin zor olması nedeniyle, bir vajinal kasecik (Keeper) vasıtasıyla toplanan ve dışarıya dog̃ru atılan adet kanı menstrüel endometriyum kaynag̃ı olarak kullanıldr. Ayrıca periton yüzeyindeki mezotel hücre örtüsü, insan ometumundan saflaştıılarak kültive edilen tek tabaka mezotel hücrelẹri ile taklit edildi.

Birinci bölümde mevcut literatur yeniden incelenirken، ikinci bölümde tezin amaçları anlatıld.

Üçüncü bölümde ıșık ve scanning mikroskopları aracilı̈ı ile adet kanı bileșkelerinin mezotel hücreleri üzerindeki potansiyel zararlı etkisi araștııldı. Bu çalıșmanın sonuçlanı adet kanındaki parakrin faktörlerin, mezotel hücrelerinde geri çekilme ve büzüșme gibi yapısal değișikliklere neden oldug̃unu ve bunun sonucu olarak hücrelerin altını döseyen bazal membran ve hücre dışı matriksin açığa çıktığını gösterdi. Bu etkinın adet kanına özgü oldug̃u düșünülmektedir, çünkü adet döngüsünün diḡer fazları olan sekretuvar ve proliferatif fazlardan elde edilen endometriyumun mezotel hücrelerinde yapısal değișikliklere neden olmadığı görülmüștür. Bu bulgular dog̃rultusunda menstrüel endometriyumun mezotel hücrelerinde bölgesel tahribata neden olarak kendisine tutunma yerleri yarattığı sonucu çıkarilı i ișiir.

Mezotel hücrelerinde gözlemlenen ve menstrüel endometriyum tarafından indüklenen deģişiklikler hücre ölümü sırasında [örneg̃in apoptozis (fizyolojik hücre ölümü) veya 
nekrozis (patolojik hücre ölümü)] veya yeniden hücre sekillenmesi sırasında görülen değișikliklere çok benzemektedir. Dördüncü bölümde bu süreçlerin hücrelerdeki morfolojik deg̈ișikliklere neden olup olmadığı araștırıldi. Apoptozis veya nekrozis göstergeleri, örnegin M30 CytoDeath antikoru ve annexin V-propidium iyodid, ile yapılan flow sitometrik analizler sonucunda, adet kanının mezotel hücrelerinin sadece \% 1-7' sinde apoptozis veya nekrozise neden oldug̃u tespit edildi. Gece boyu yapılan inkübasyonlar sonucunda elde edilen bu veri fizyolojik sınırlar çerçevesindedir. Buna karşın, hemen hemen tüm mezotel hücrelerinin görünümü adet kanın etkisiyle değișmiştir. Sitokeratin, vimetin ve fibriler aktin (hücre iskelet proteinleri) için yapılan immün boyamalar, mezotel hücrelerinde gözlenen bu büyük değişiklişin iskelet proteinlerinin tekrardan düzenlenmesi ile yakın ilişkili oldug̃unu göstermiștir. Dolayısıyla, gözlenen yapısal deg̃ișikliklerin altında yatan nedenin apoptozis ve nekrozdan ziyade yeniden hücre şekillenmesi oldug̃u sonucuna varılmıştır.

Epitel hücre yapısından mezenkimal hücre yapısına geçis (epitelyal-mezenkimal transizyonlar, EMT) yeniden hücre șekillenme formlarından biridir. Bu nedenle beșinci bölümde mezotel hücrelerindeki bu süreci morfoljik ve moleküler seviyede inceledik. Time-lapse video mikroskopisi yardımı ile adet kanı etkisi altında kalan mezotel hücrelerinin dinamik bir süreçten geçtiklerini gözlemlendik. Bu süreç hücre temas noktalarının birbirinden aynlması, hücrelerin hareketliliginin artması ve hücre uzantılarının olușmasını kapsamaktadır. Bir günlük inkübasyon süreci içerisinde mezotel hücreleri bu dinamik deg̃ișiklikleri olușturarak iğimsi veya yuvarlak bir forma ulaștılar. Hücre kültür ortamı, adet kanını içermeyen normal hücre ortams ile degisstirildiği zaman mezotel hücreleri dört gün içerisinde tipik görünümlerini tekrar kazandılar. Bu gözlemlere dayanarak, adet kanının mezotel hücre morfolojisinde geri dönüșümlü degișikliklere yo! açı̆ğı ve periton yüzeyinde kalıc hasara neden olmadig̨ı sonucuna vardik. Ayrica mezotel hücrelerinde görülen yeniden hücre şekitlenmesinin EMT olduğuna dair bulgulara da ulaștik. Inhibisyon çalıșmaları, deg̃ișen morfolojinin (Src) tirozin kinaz sinyal yolu katılımını içeren ve enerjiye bag̈ımlı bir geçiș süreci oldug̃unu göstermiștir. Ayrıca vimentin ve transkripsiyon faktörlerinin ekspresyonu artarken, E-cadherin ekspresyonu belirgin olarak azalmıș, sitokeratin subtiplerinin ekspresyonu ise değișiklikler gôstermiştir.

Altıncı bölümde mezatel hücrelerindeki EMT'yi belirleyen hücresel proteinlerdeki fonksiyonel degișiklikler degerlendirildi. Adet kanına özgün faktörlerin karmașik bir süreç olan EMT ile alakalı, düzenleyici, metabolik ve yapisal proteinlerin ekspresyon ve fosforilasyon durumlạında değișiklikleri bașlattığını gösterdik. Bu veriler doğrultusunda söz konusu sürece katkıda bulunan sinyal yollarını belirledik. Örneğin büyüme faktör reseptörleri ile ilintili tirozin kinaz aktivitesinin bir substratı olan annexin- 1 'in fosforile olması, mezotel hücrelerinde EMT-sinyalinin iletilmesinde (Src) tirozin kinaz yolunun katilıminı göstermektedir. Dahası, Rho ailesine ait olan küçük G proteinleri ile ilintili proteinlerin ekspresyonlarının deḡișmesi, adet kanının EMT'yi uyanı sinyali Ras, Rho ve MAPK sinyal yollan üzerinden de aktardığını göstermektedir. Tropomiyozin-a' nın fosforile olması, aktin ve tubuline bağlanan proteinler ile sitokeratin ve vimentin filamanlarının ekspresyonlarının 
değișmesi, sinyalin hücre iskelet proteinelerinde, ve özellikle aktin filamanlarının yeniden düzenlenmesinde sonlandığını göstermektedir. Dolayısıyla bu durum mezotel hücrelerinde fenotipik deḡișikliklere neden olmaktadır. Bu bölümde mezotel hücrelerinin proteom yapısı ile ilgili ek bilgiler de sunulmuștur.

Mezotel hücrelerinde EMT sürecinin daha iyi anlașilabilmesi için adet kanındaki uyanı faktörlerin karakterize edilmesi ve (mümkün oldug̃u takdirde) belirlenmesi gerekmektedir. Yedinci bölümde bu faktörleri saflaștırmak ve karakterize etmek için stratejiler geliștirilmiștir. Matriks metalloproteinazlarını bloke eden spesifik maddelerle yapılan inkübasyonlar, iNOS ekspresyonunun deg̃erlendirilebilmesi için kullanılan RT-PCR ve nitrotirozinin görüntülenmesi için kullanilan immün boyamalar sonucunda, bu moleküllerin mezotel hücrelerindeki EMT sürecine dahil olmadıkları ortaya konmuștur. Ayrıca büyüklüklerine göre ayrıștırma teknikleri EMT sürecinden sorumlu olan çözünebilir faktörlerin protein tabiatında olduklarını ve 50 kD molekül ağırlığından daha büyük olduklarını göstermiștir. Daha sonra uygulanan proetomiks teknikleri iki proteinin kimlīinini ortaya çikarmıștır: $\alpha$-enolaz ve hemoglobin. $\alpha$-Enolazın bir plazminojen reseptörü ve (Src) tirozin kinaz proteinlerinin substratı olması, ve hemoglobinin aktin iskeletini tirozin kinaz sinyal yolu üzerinden değiștirebilmesi, bu iki proteinin mezotel hücreierinde EMT'yi uyarıyor olabileceklerini ortaya koymaktadır.

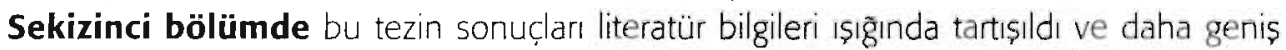
bir perspektif sunuldu. Ayrıca gelecekte yapliacak çalıșmalar için önerilerde butunuldu.

Özet olarak bu çalıșmanın sonuçları, karın boşiug̃una đökülen menstrüel endometriyum ile buradaki mezotel hücrelerinin etkileșme noktasında ki moleküler mekanizmaların daha da detaylandıılmasını sağlamıștır. Adet kanı mezotel hücrelerinde bir geçiș sürecini bașiatabilmekte ve bu hücreler fenotiplerini epitelden fibroblast tipine değiștirebilmektedirler. Bazı sinyal iletim yolları, özellike tirozin kinazlar bu geçiss sürecinde rol almaktadirlar. Adet kanındaki çôzünebilir moleküller mezotel hücrelerinde sinyal iletimi için potansiyel adáylardir. 


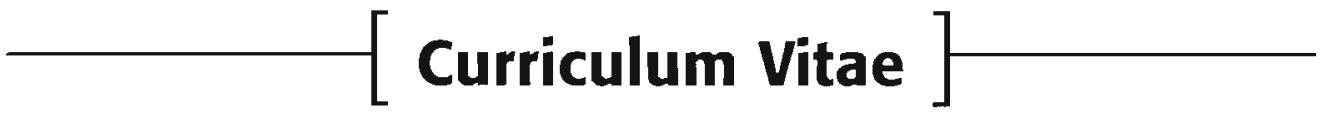

Ayșe Yasemin Demir werd op 2 mei 1970 te Elaziğ, Turkije geboren. Op 12 januari 1994 studeerde zij af aan de Faculteit der Geneeskunde van de Akdeniz Universiteit te Antalya, Turkije. Vervolgens begon zij met haar promotieonderzoek op de afdeling Biochemie aan dezelfde universiteit. In 1995 bemachtigde zij een TÜBITAK-beurs (Wetenschappelijke en Technische Raad van Turkije) om haar promotieonderzoek aan het Instituut voor Anatomie van de RWTH te Aken, Duitsland uit te uitvoeren (begeleider Prof. Dr. P. Kaufmann). In 1999 verdedigde zij haar proefschrift: "The extracellular matrices in human term placenta: The distribution of fibronectin isoforms and matrix metalloproteinases" in zowel Turkije als Duitsland. Hiermee verdiende ze haar Doktorstitel (Dr.) in de Biochemie van de Akdeniz Universiteit van Antalya, Turkije. In Aken werd zij Doktor der Medizin (Dr.med.). In juni 1998 startte zij met het onderzoek beschreven in dit proefschrift. Het werd uitgevoerd binnen het onderzoeksinstituut Groei en Ontwikkeling (GROW, wetenschappelijk directeur Prof. Dr. J. de Haan) van de Universiteit Maastricht, afdeling Obstetrie en Gynaecologie (begeleider Prof. Dr. J.L.H. Evers) in samenwerking met de afdeling Pathologie (hoofd Prof. Dr. M. Daemen). Sinds 1 april 2003 is zij in opleiding tot Klinisch Chemicus aan het Universitair Medisch Centrum te Utrecht (opleider Prof. Dr. W.W. van Solinge). Naast deze werkzaamheden is zij echtgenote en moeder van twee kinderen: Timur (bijna 4 jaar), en diens nog ongeboren bruertje of zusje. 


\section{List of Publications}

Demir, R., Kaufmann, P., Demir, A. Y., Erbengi, T., Kaya, M. (1994) Cellular diversity of human placental villi core. Tr J Med Sci, 20,149-153.

Demir, R., Demir, A. Y., Erbengi, T. (1994) Some ultrastructural observations on cell death associated with intracellular inclusion fromation. Tr J Med Sci, 20, 139-147.

Demir, A. Y., Demir, N., Agar, A., Demir, R. (1994) The protective effect of ginkgo biloba extract (Egb) on median preoptic area (MPOA) and adenohypophysis in diabetic rats: a morphometric study. Tr J Med Sci, 22, 253-257.

Demir, R., Demir, A. Y., Yinanc, M. (1994) Structural changes in placental barrier of smoking mother. A quantitative and ultrastructural study. Pathol Res Pract, 190, 656-667.

Demir, R., Demir, A. Y., Erbengi, T. (1995) intranuclear inclusion bodies in placental septal cells and their possible relation in placental cell degeneration. J Obst and Gynaecol, 15 , 88-97.

Gumuslu, S., Demir, A. Y., Yucel, G., Yesilkaya, G., Aydin, M., Aksu, T. A. (1996) Antioxidant role of bovine albumin detected by a chemiluminescence method. Tr J Med Sci, 26, 431-434.

Gumuslu, S., Yucel, G., Aydin, M., Yesilkaya, A., Demir, A. Y., Aksu, T. A. (1996) The role of antioxidants in the prevention of t-butyl hydroperoxide-induced chemiluminescence. Int J Clin Lab Res, 26, 119-123.

Huppertz, B., Kertschanska, S., Demir, A. Y., Frank, H. G., Kaufmann, P. (1998) Immunohistochemistry of matrix metalloproteinases (MMP), their substrates, and their inhibitors (TIMP) during trophoblast invasion in the human placenta. Cell Tissue Res, 291, 133-148.

Koks, C. A., Demir Weusten, A. Y., Groothuis, P. G., Dunselman, G. A., de Goeij, A. F., Evers, J. L. (2000) Menstruum induces changes in mesothelial cell morphology. Gynecol Obstet Invest, 50, 13-18.

Demir Weusten, A. Y., Groothuis, P. G., Dunseiman, G. A., de Goeij, A. F., Arends, J. W., Evers, J. L. (2000) Morphological changes in mesothelial cells induced by shed menstrual endometrium in vitro are not primarily due to apoptosis or necrosis. Hum Reprod, 15, 1462-1468. 
Aliciguzel, Y., Ozdem, S., Demir, A. Y., Unal, F., Kumbul, D., Ozdem, S. S., Perry, G., Smith, M. A. (2001) Effect of the herbicide 4-CPA on human erythrocyte antioxidant enzymes in vitro. Redox Rep, 6, 153-154.

Gaus, G., Demir Weusten, A. Y., Schmitz, U., Bose, P., Kaufmann, P., Huppertz, B., Frank, H. G. (2002) Extracellular pH modulates the secretion of fibronectin isoforms by human trophoblast. Acta Histochem, 104, 51-63.

Demir, R., Kayssl, U. A., Celik-Ozenci, C., Korgun, E. T., Demir Weusten, A. Y., Arici, A. (2002) Structural Differentiation of human uterine luminal and glandular epithelium during early pregnancy: An ultrastructural and immunohistochemical study. Placenta, 23, 672-684.

Nap, A. W., Groothuis, P. G., Demir, A. Y., Maas, J. W. M., Dunselman, G. A. J., de Goeij, A. F. P. M., Evers, J. L. H. (2003) Tissue integrity is essential for ectopic implantation of human endometrium. Hum Reprod, 18, 30-34.

Demir, A. Y. (2003) Fibronectin isoforms in the extracellular matrix of human term placenta. Early Pregnancy, 6, $214-234$.

Demir, R., Kayisli, U. A., Celik, C., Korgun, E. T., Demir Weusten, A. Y. (2003) Ultrastructural diversities of the human decidual granular leucocytes during early pregnancy. Early Pregnancy, 6, 248-271.

Demir, A. Y., Groothuis, P. G., Nap, A. W., Punyadeera, C., de Goeij, A. F. P. M., Evers, J. L. H, Dunselman, C. A. J. (2004) Menstrual effluent induces epithelial to mesenchymal transitions in mesothelial cells. Hum Reprod, 19, $21-29$.

Nap، A. W., Groothuis, P. G., Demir, A. Y., Evers, J. L. H, Dunselman, G. A. J. (2004) Pathogenesis of endometriosis. Best Practice \& Research Clinical Obstetrics and Gynaecology 2004, in press.

Demir, R., Kayisli, U. A., Seval, Y., Celik-Ozenci, C., Korgun, E. T., Demir-Weusten, A. Y., Huppertz B. (2004) Sequential expression of VEGF and its receptors in human placental villi during very early pregnancy: Differences between placental vasculogenesis and angiogenesis. Placenta, in press.

Demir, A. Y., Dunselman, G. A. J., Puype, M., Demol, H., Herrler, A., de Coeij, A. F. P. M, Evers, J. L. H., Vandekerckhove, J., Groothuis, P. G. Proteome analysis of human mesothelial cells during epithelial to mesenchymal trasitions induced by shed menstrual effluent. Submitted. 
Demir, A. Y., Groothuis, P. G., Dunselman, G. A. J., Schurgers, L. J., Evers, J. L. H., de Goeij, A. F.P.M. Molecular characterization of soluble factors from human menstrual effluent that induce epithelial to mesenchymal transitions in mesothelial cells. Submitted. 


\section{Appendix}

Proposed model for involvement of identified molecules in mesothelial EMT. The molecules indicated in bold-italics text are identified and discussed in this thesis.

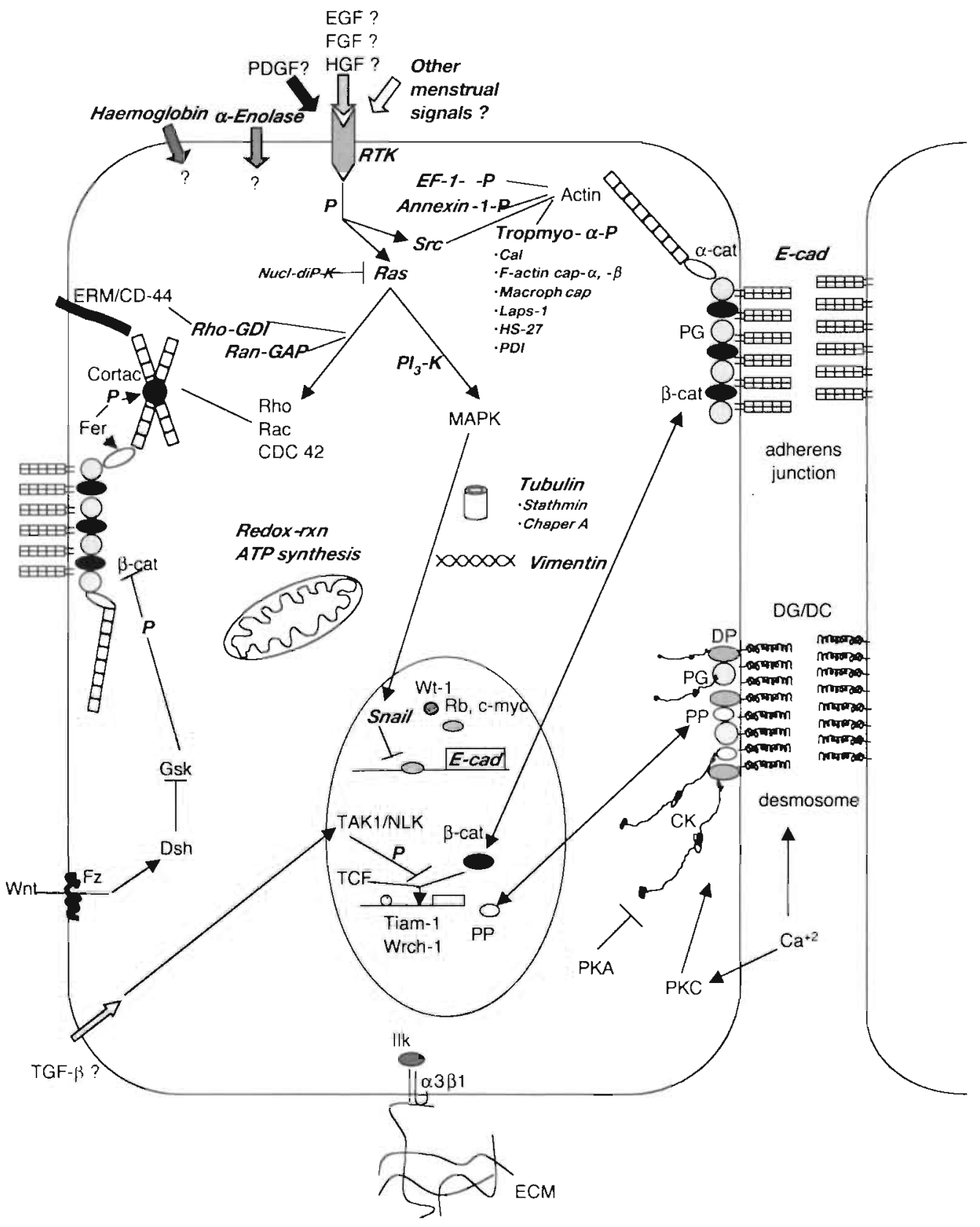


Mesothelial cells express mesenchymal markers such as vimentin and change their epithelial characteristics, e.g. they down-regulate the expression of some types of cytokeratins. The organization of microtubules is also affected during this process. As a result the cells dissociate from each other, spread and migrate. One or more menstrual signals, i.e. various growth factors, differentiation factors, enzymes or extracellular matrix molecules, may initiate the EMT by activating the Ras and Src pathways. After culture in menstrual effluent, the cell-cell adhesion structures such as adherens junctions and desmosomes in mesothelial cells are loosened. Several mechanisms contribute to the perturbation of cadherin/ catenin linkage and the anchoring of actin to the membrane in adherens junctions, and desmosomes.

After a lateral dimerization of homophilic cadherin subunits between adjacent cells, a weak adhesion is generated. The involvement of $\mathrm{Ca}^{2+}$, catenins and other molecules mediating linkage to the actin cytoskeleton strengthens this adhesion. One of the ways to perturbate adherens junctions is reduction of the level of E-cadherin by up-regulating the expression of transcription factor Snail. As a result $\beta$-catenin is relocalized to the nucleus to activate a specific transcriptional activity. Furthermore, binding of Wht ligands to the Fz receptors promotes cell motility by weakening adherens junctions. The integrin-ECM pathway regulates actin microfilament local organization and interferes with cadherin function by displacing modulators such as Fer. In desmosomes the formation requires $\mathrm{Ca}^{2+}$ availability and transcriptional activity. One of the regulatory pathways is through PKC, a kinase, which enhances the adhesion, whereas PKA destabilizes this.

\section{Abbreviations used:}

$\alpha$-cat: $\alpha$-catenin, $\alpha 3 \beta 1$ : integrin $\alpha 3 \beta 1$ 1, $\beta$-cat: $\beta$-catenin, Cal: caldesmon, Cortac: cortactin, CK: cytokeratins, DC: desmogleins, DC: clesmocollins, DP: desmoplakins, Dstr: dishevelled, E-cad: E-cadherin, EF-1- $\Delta$ : elongation factor-1- $\Delta$, ERM: ezrin-radixin-moesin family, F-actin cap- $\alpha,-\beta$ : F-actin capping protein- $\alpha,-\beta$, Fer: a non-transmembrane tyrosine kinase, Fz: frizzeled, HS-27: heat shock protein-27, Ilk: a subtype of phosphotidylinositol phosphate kinase, Laps- I: LIM \& SH3 domain protein 1, Macroph cap: macrophage capping protein, MAPK: mitogen activated protein kinase, Nucl-dip-K: nucleoside diphosphate kinase, PDl: protein disulphate isomerase inhibitor, PG: plakoglobin, PP: plakophilin, P: phopshorylation, $\mathrm{Pl}_{3}-\mathrm{K}$ : phosphatidyl inositol-3-kinase, $\mathrm{PKA}$ : protein kinase $\mathrm{A}, \mathrm{PKC}$ : protein kinase $\mathrm{C}, \mathrm{Rb}$ : retinoblastoma protein, Rho-GDI: Rho GDP dissociation inhibitor, Ran-GAP: Ran specific GTPase activating protein, RTK: receptor tyrosine kinase, TCF: T-cell factor, Tropmyo- $\alpha$ : tropomyosin- $\alpha$, Wt-1 : DNA binding zinc finger protein associated with Wilms' tumour locus 


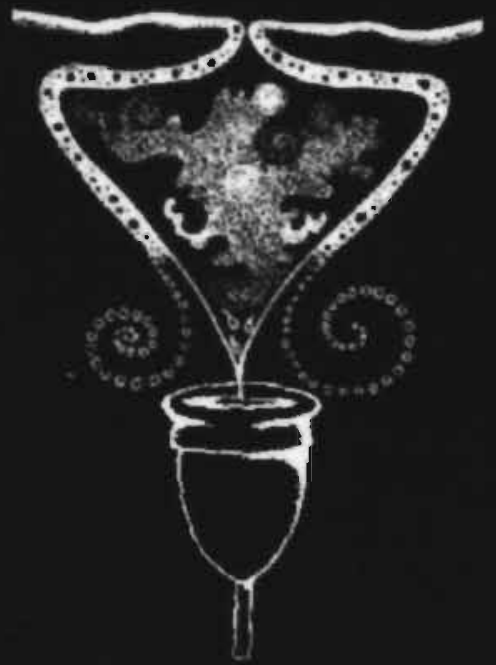

ISBN 90-9017871-6 